\title{
Médicos e farmacêuticos na terapia popular: uma trajetória de suas profissões no estado de São Paulo e na Inglaterra (1815-1930)
}

\section{Paula Yuri Sugishita Kanikadan}

Tese apresentada ao Programa de Pós-Graduação em Saúde Pública da Faculdade de Saúde Pública da Universidade de São Paulo para obtenção do título de Doutor em Saúde Pública

Área de Concentração: Prática de Saúde Pública Orientador: Profa. Dra. Maria Cristina da Costa Marques

São Paulo

2010 
Para Manoel 
Este estudo foi realizado com o auxílio financeiro da ANVISA (processo 2001.1.1048.6.9), CAPES (processo 0135-08-9) e CNPq (processo 141148/2009-8) 
"Todos nós costumamos rir das crendices...

É um riso exterior e postiço, com que mascaramos o nosso medo. É de crer que, para não perder o seu ganha-pão, os delegados de polícia, obedecendo às ordens do chefe, varejem as casas das cartomantes; muitos deles, porém, cumprirão esse dever com um certo terror. $\mathrm{E}$ até $\mathrm{o}$ chefe...quem sabe que superstições terá o chefe? A investidura de tão alto cargo não destrói dentro da alma de um homem as estratificações de preconceitos que séculos e séculos de humanidade e de fraqueza têm deposto nas almas de todos os homens."

Olavo Bilac, As Cartomantes, 1901 


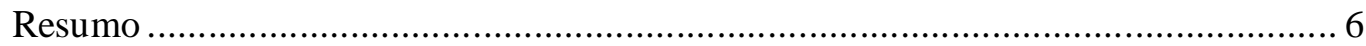

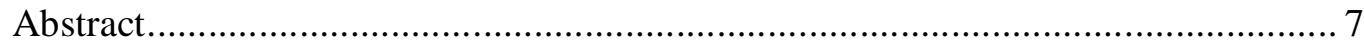

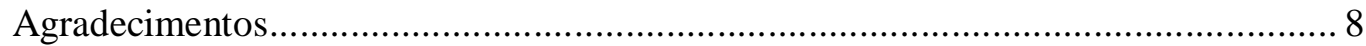

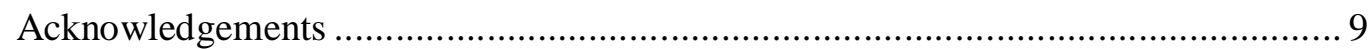

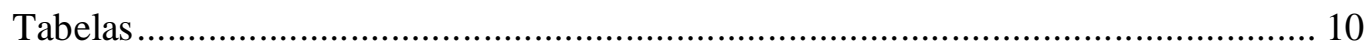

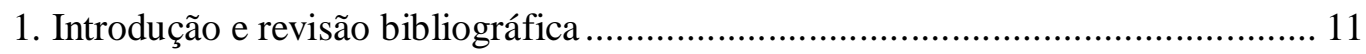

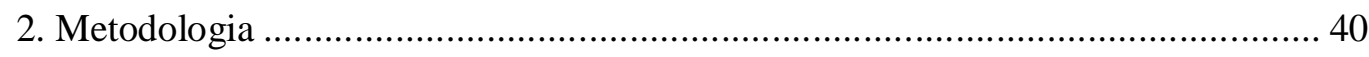

3. Um olhar comparativo entre São Paulo e Inglaterra ........................................... 51

3.1. Condições de saúde durante o período de industrialização........................... 51

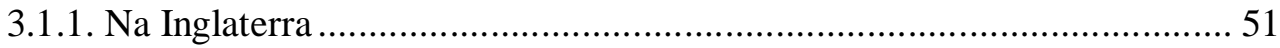

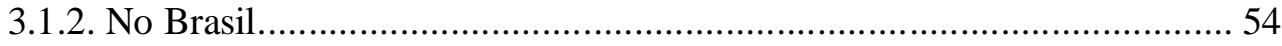

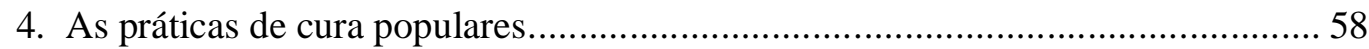

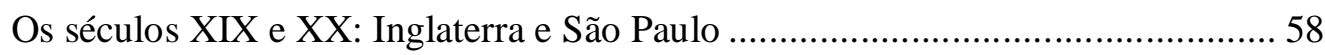

5. Químicos e droguistas, apotecários e cirurgiões na Inglaterra............................. 71

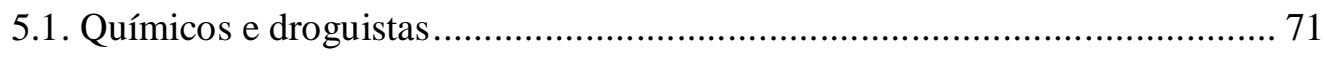

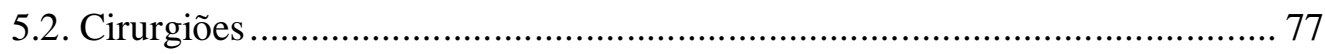

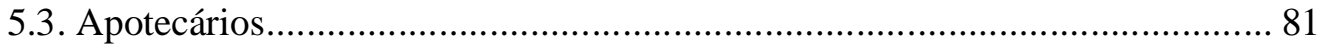

6. Farmacêuticos em São Paulo e na Inglaterra …................................................... 86

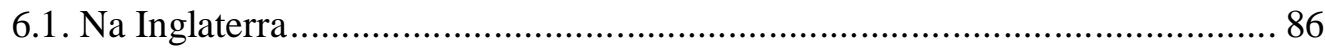

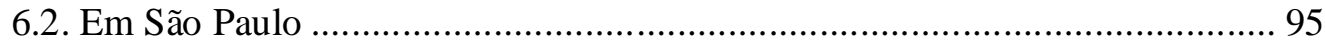

6.3. Aproximações entre farmacêuticos ingleses e paulistas ............................. 119

7. Médicos em São Paulo e na Inglaterra ....................................................... 123

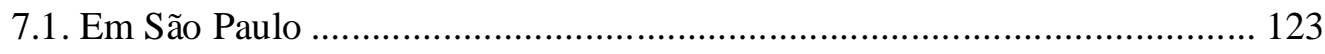

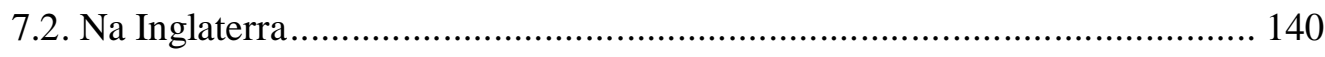

7.3. Amarrando as funções de médicos na Inglaterra e em São Paulo .................. 150

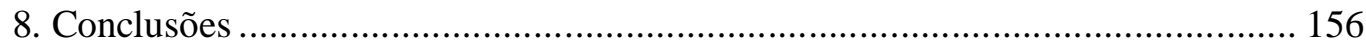

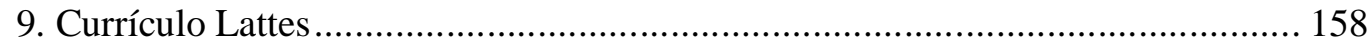

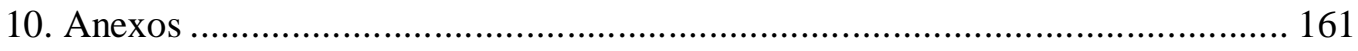

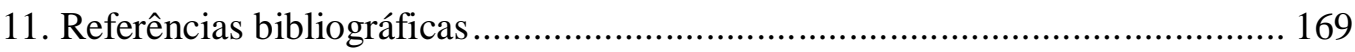




\section{$\underline{\text { Resumo }}$}

As práticas de cura populares, como a busca por terapeutas populares e medicamentos caseiros, foram um recurso bastante buscado para combater doenças. O exercício destas atividades populares descontentava alguns profissionais de saúde, e médicos e farmacêuticos envolveram-se profissionalmente para tentar controlar a prática da terapia popular. Neste sentido, almejamos analisar como médicos e farmacêuticos no estado de São Paulo, do período que compreendeu os anos 1892-1930, bem como os profissionais médicos e farmacêuticos ingleses, que atuaram entre 1815-1930, influenciaram nas mudanças legislativas da terapia popular. Para tanto, utilizamos uma perspectiva histórico-comparativa, partindo das reformas legislativas em saúde nos dois locais para compreender como médicos e farmacêuticos envolveram-se profissionalmente no combate às práticas de cura populares. Com isso, fatos como as epidemias da época e o comércio de medicamentos influenciaram na trajetória destes profissionais de saúde. Médicos, em especial, tiveram suas profissões destacadas após a investigação da trajetória profissional de apotecários e cirurgiões na Inglaterra. Farmacêuticos, na sequência, dependeram também dos caminhos trilhados especialmente por químicos e droguistas, trazendo novas conformações para as práticas de medicina popular exercidas pelos diversos charlatães ingleses do século XIX. Em São Paulo, a reorganização do espaço profissional após a nova legislação sanitária de 1892 no estado criava condições para que médicos ganhassem um lugar importante no campo da medicina e, ao lado de farmacêuticos, foram se adequando às necessidades públicas para se promoverem em suas profissões. Farmacêuticos, por sua vez, tentavam consolidar seu espaço na área de saúde especialmente 'pegando carona' no inicial desenvolvimento da indústria de medicamentos em São Paulo. Concluiu-se que a terapia popular, embora ainda presente, foi passando por transformações em decorrência do desenvolvimento das profissões de saúde ao longo dos períodos respectivos considerados. O estabelecimento destas profissões de saúde mostrou uma mistura de interesses profissionais pessoais, em paralelo às necessidades da saúde pública, com o objetivo de melhorar as condições da população do estado de São Paulo e da Inglaterra.

Palavras-chave: terapia popular, médicos, farmacêuticos, legislação, controle, saúde. 


\section{Abstract}

Popular medicine was a health resource very much searched to combat diseases in the nineteenth and twentieth centuries. Indeed the search of popular healers and domestic medicines were some of these popular practices. Some health professionals, such as physicians and pharmacists, were aware of the exercise of these popular practices. These health professionals have been involved in this issue in an attempt to control the practice of popular medicine. In this context, we aimed to analyse how physicians and pharmacists have influenced on the legislative changes of popular therapy. We considered two places in this study: São Paulo state from 1892 to 1930, and England, from 1815 to 1930. To achieve this goal, we utilized a historical-comparative perspective, which has commenced on the health legislative reforms in both places. The aim of this beginning was based on the understanding of how physicians and pharmacists have professionally worked on to control popular medicine. In this way, facts such as the epidemics and the trade of medicines have influenced in the professional course of them. Physicians have had their professions highlighted after the investigation of the professional trajectory of apothecaries and surgeons in England. Next, pharmacists have worked according to the professional procedures of the chemists and druggists. This action of both physicians and pharmacists has resulted in new insights for popular medicine which was executed by many English quacks of the nineteenth century. In São Paulo state, the reorganization of the professional space after the new sanitary legislation in 1892 has created other conditions for physicians. They have acquired an important place in medicine, and together with pharmacists, physicians were making themselves comfortable in order to achieve their professional goals. Pharmacists have tried to consolidate their place in health with the initial development of the pharmaceutical industry in São Paulo. We concluded that popular medicine, despite its presence today, was passing through changes due to the development of the health professions in each considered period. The establishment of these professions has shown a mixture of personal and professional interests, in parallel with public health purposes. All of these issues were connected with the improvement on health conditions of the people from São Paulo state and England.

Key-words: popular medicine, physicians, pharmacists, legislation, control, health. 


\section{Agradecimentos}

À Profa. Dra. Maria Cristina da Costa Marques, pelos ensinamentos e pela confiança.

Ao Dr. Stephen Bury, The British Library, pela supervisão do doutorado 'sanduíche' em Londres; ao Prof. Dr. Stuart Anderson, da London School of Higiene \& Tropical Medicine, pelo apoio durante o período na Escola.

Aos integrantes do Grupo do Centro de História da London School of Higiene \& Tropical Medicine, Profa. Dra. Virginia Berridge, Profa. Dra. Alex Mold, Prof. Dr. Martin Gorsky, Susanne Taylor e Ingrid James, pela receptividade e pelos ensinamentos; agradecimentos especiais para Jennifer Walke, pela amizade e pelo aprendizado.

Ao Prof. Dr. André Mota e ao Prof. Dr. Paulo Roberto Miele pelos ensinamentos e pelas sugestões na fase final da redação da tese.

A Eric Green, à Ya Feng e ao Sr. Tieshung Wu, pela amizade; à Catia Alves de Senne, pelos ensinamentos durante a fase inicial do estudo.

À Vânia e à Renilda, da Seção de Aprimoramento da Faculdade de Saúde Pública da Universidade de São Paulo, pelo suporte técnico durante os estudos.

A todos os bibliotecários e funcionários das bibliotecas e arquivos das Faculdades de Saúde Pública, de Medicina, do Conjunto das Químicas e de Filosofia, Letras e Ciências Humanas da Universidade de São Paulo; da Secretaria de Estado da Saúde de São Paulo; do Arquivo Público do Estado de São Paulo; da London School of Higiene \& Tropical Medicine; da Wellcome Library e da British Library.

Aos meus pais, pelo constante incentivo.

À Vivian e ao Leonardo, pelo apoio durante a execução da tese.

À Andréa, por todos os percursos trilhados juntas.

A Manoel, por tudo o que representa em minha vida. 


\section{Acknowledgements}

I am sincerest thankful to Prof. Dr. Maria Cristina da Costa Marques, who has supported me throught my thesis with her confidence and knowledge.

I offer my sincerest gratitude to Dr. Stephen Bury, from The British Library, who has supervised me during the 'split' $\mathrm{PhD}$ in London; I am also very thankful for the support of Prof. Dr. Stuart Anderson, from London School of Hygiene \& Tropical Medicine during my stay at School.

The staffs of the Centre for History in Public Health from London School of Hygiene \& Tropical Medicine have received me with receptivity and knowledge: Prof. Dr. Virginia Berridge, Prof. Dr. Alex Mold, Prof. Dr. Martin Gorsky, Miss Susanne Taylor and Mrs. Ingrid James; I offer special acknowledgements to Miss Jennifer Walke, for the friendship and teachings.

Prof. Dr. André Mota and Prof. Dr. Paulo Roberto Miele have offered me much advice and insight in the end of the work.

I appreciate the friendship of Eric Green, Mrs. Ya Feng and Mr. Tieshung Wu; Catia Alves de Senne offered me advice during the beginning of the $\mathrm{PhD}$ in Brazil.

Vânia and Renilda, from the Seção de Aprimoramento of Faculdade de Saúde Pública from Universidade de São Paulo, have proportioned me technical support during my study.

To the staffs of the libraries and archives from Faculdade de Saúde Pública, Faculdade de Medicina, Conjunto das Químicas and Faculdade de Filosofia, Letras e Ciências Humanas of Universidade de São Paulo; from Secretaria de Estado da Saúde de São Paulo; from Arquivo Público do Estado de São Paulo; from London School of Higiene \& Tropical Medicine; Wellcome Library and The British Library.

I offer my gratitude to my parents, for the constant support.

Vivian and Leonardo have contributed to my study.

Andréa shares every moment in my life.

Manoel represents all the things in life. 


\section{$\underline{\text { Tabelas }}$}

Tabela 1 - Tabela de medicamentos na medicina doméstica por um cirurgião inglês

Tabela 2 - Lista de medicamentos publicada por farmacêuticos em São Paulo

Tabela 3 - Resumo das profissões de saúde na Inglaterra - séculos XVIII/XIX 


\section{Introducão e revisão bibliográfica}

Os cuidados informais com a própria saúde tornaram-se ferramenta importante para a adequação das políticas de saúde pública às necessidades da população. Há um debate intenso entre profissionais de saúde e autoridades públicas com o intuito de estabelecer normas que atendam a estas demandas públicas na saúde (Gorsky \& Sheard, 2006; Barros, 2004; Porter, 1997; Paulo \& Zanini, 1988; Marland, 1987). Segundo a OMS (1998), este cuidado que parte de decisões pessoais do próprio indivíduo denomina-se auto-cuidado, um conceito amplo que engloba a higiene, a nutrição, o estilo de vida, os fatores ambientais, os fatores sócio-econômicos e a automedicação. Com efeito, existem diversos dados epidemiológicos que confirmam a relevância das práticas de automedicação na construção de novas políticas em diversos países ${ }^{1}$.

Atualmente, a World Self-Medication Industry (2004) considerou que a automedicação é o tratamento de problemas comuns de saúde por meio de medicamentos $^{2}$ destinados para a utilização na ausência de supervisão médica e aprovados como seguros e eficazes para tal uso. Denomina-se 'automedicação responsável'. Tais medicamentos incluiriam ervas e produtos tradicionais (OMS, 1998).

Entretanto, reforçam-se também os perigos no mau uso de medicamentos (Ministério da Saúde, 2002): “...muitas vezes utilizamos medicamentos sem receita médica, ou sem a indicação de um profissional de saúde...”. (p. 58) "Nas farmácias,

\footnotetext{
${ }^{1}$ Consultar: Vamvakopoulos JE et al. Lifestyle or life-saving medicines? A primary healthcare professional and consumer opinion survey on over the counter statins. Ann Pharmacother. $2008 \mathrm{Mar}$, 42 (3): 413-20; McWhirter e col. Can schools promote the health of children with asthma? Health Educ Res., vol. 23, n. 6, p. 917-30, dez. 2008; Berry, D.; Bradlow, A.; Courtenay, M. Patients' attitudes towards, and information needs in relation to, nurse prescribing in rheumatology. J Clin Nurs., vol. 17, n. 2, p. 266-73, Jan 2008; Purssell e col. Treatment of fever and over-the-counter medicines. Arch Dis Child., vol. 92, n. 10, p. 900-1, out 2007; Rutter PM et al. Evaluation of community pharmacists' recommendations to standardized patient scenarios. Ann Pharmacother. 2004 Jun, 38 (6): 1080-5.

Loyola-Filho e col. Bambuí Project: a qualitative approach to self-medication. Cad. Saúde Pública, vol. 20, n. 6, p. 1661-9, 2004; Santos, K. M. O.; Barros Filho, A. A. Consumo de produtos vitamínicos entre universitários de São Paulo, SP. Rev Saúde Pública, vol. 36, n. 2, p. 250-3, 2002; Arrais e col. Perfil da automedicação no Brasil. Rev. Saúde Pública, vol. 31, n. 1, p. 71-7, 1997.
}

\footnotetext{
${ }^{2}$ De acordo com o Minidicionário da Língua Portuguesa Aurélio Buarque de Holanda Ferreira (1977), o termo 'medicamento' significa toda a "Substância ou preparado que se utiliza como remédio." (p. 311), e o termo 'remédio', "Aquilo que combate, cura ou alivia mal, dor ou doença.” (p. 411). Ressaltase aqui que todo medicamento é um remédio, mas nem todo remédio é um medicamento. Assim, utilizamos, ao longo do estudo, a palavra medicamento para nos referirmos às fórmulas medicamentosas e, algumas poucas vezes, referimo-nos ao termo 'remédio' como forma de auxílio, de recurso. Não modificamos as citações que mencionaram a palavra 'remédio'.
} 
quando as pessoas recebem a indicação de um medicamento por um balconista, também estão se automedicando, e o que é pior, estão sendo induzidos pelo interesse comercial de quem ganha dinheiro vendendo medicamentos" (p. 58).

Neste contexto, alguns profissionais da área de saúde possuem papel importante nas orientações sobre as doenças e os medicamentos, e elencamos, para este estudo, médicos e farmacêuticos como os profissionais que atuam diretamente nestas formas de assistência à saúde. Médicos são os profissionais responsáveis pelo diagnóstico das doenças e pela seleção da terapêutica, seja ela medicamentosa ou não ${ }^{3}$, ao passo que farmacêuticos, pela avaliação técnica da terapia escolhida pelos médicos. Desta forma, ambos os profissionais assumem responsabilidade legal para gerar segurança nos cuidados com a saúde, e um destes cuidados engloba as orientações quanto às práticas de automedicação (Barros, 2004; Pfuetzenreiter, 2001; Lopes, 2001; Paulo \& Zanini, 1988).

Hoje, a legislação determina regulamentações para que médicos e farmacêuticos atuem de forma a auxiliar o paciente que busca tratamento médico. Entretanto, a ausência deste controle marcou o desenrolar dos séculos. Apesar da permanência das práticas de cura popular, o percurso das profissões de medicina e de farmácia trouxe outros olhares para médicos e farmacêuticos envolvidos, bem como da população que procura as artes de curar: questões culturais e a própria vontade do paciente de escolher seu tratamento influenciaram nas mudanças dessas profissões de saúde ao longo do tempo (Lopes, 2001; Porter, 1997; Schraiber, 1997; Marland, 1987).

A partir das regulamentações no uso de medicamentos e na diagnose clínica, atreladas às mudanças legislativas nas funções desses profissionais de saúde, alterouse a procura pela chamada 'terapia popular' (Anvisa, 2003; Thomas, 1997). Aqui neste ponto cabe uma nota sobre a utilização do termo 'terapia popular' no presente estudo. Consideramos terapia popular como qualquer prática de cura não-científica. Foram contemplados quaisquer métodos de cura não orientados por consulta de um

\footnotetext{
${ }^{3}$ A Organização Mundial de Saúde tem estimulado não somente a automedicação responsável, como criou um espaço para outras práticas alternativas de cura, além da alopatia: intitulou, em 2002, "Estratégias da Medicina Alternativa". Assim, o Sistema Único de Saúde Brasileiro criou uma "Política Nacional de Práticas Integrativas e Complementares" por meio da portaria do Ministério da Saúde n. 971, de 3 de maio de 2006, com destaque para a homeopatia, acupuntura, termalismo, meditações, orações, o uso de plantas medicinais e fitoterápicos. Consultar: Tesser, C.D. \& Barros, N. F. Medicalização social e medicina alternativa e complementar: pluralização terapêutica do Sistema Único de Saúde. Rev Saúde Pública, vol. 42, n. 5, p. 914-920, 2008.
} 
profissional médico: o uso de medicamentos caseiros, comprimidos, soluções, a busca por terapeutas populares como curandeiros, charlatães, o conselho 'médico' do 'vizinho', as práticas mágicas e religiosas. Outras nomenclaturas para terapia popular foram utilizadas ao longo do estudo: medicina popular, artes de cura, práticas populares de cura, terapia alternativa, auto-cuidado, práticas médicas. Seguindo os argumentos de Queiroz (1993): “...definimos medicina popular como sendo todas as representações e práticas relativas à saúde e à doença que se manifestam independentemente do controle da medicina oficial, ou seja, aquela medicina institucionalizada e regulamentada pelo poder público constituído.” (p. 274).

Existem poucos trabalhos que versam sobre os terapeutas populares na Primeira República Paulista no período selecionado do estudo. A maioria dos estudos analisa as condições de terapeutas populares atuando no período imperial do Rio de Janeiro. A dificuldade encontrada nos documentos em classificar os vários tipos de terapeutas populares levou-nos a estabelecer a nomenclatura 'terapia popular' para designar quaisquer tipos de práticas não-científicas conduzidas por quaisquer indivíduos sem a habilitação oficial. Silva (2004) argumenta que a profissão de médico na Primeira República, que ganhava seu espaço, esteve associada às práticas de charlatães - pois os jovens conhecimentos médicos misturavam-se aos conhecimentos populares e desonestos dos charlatães, confundindo os ofícios de cada profissional, seja ele médico, seja ele terapeuta popular. Careli (2008) nota em seu estudo sobre as parteiras do período republicano que as autoridades governamentais consideravam-nas charlatãs por causa de sua “...imperícia profissional e da associação das parteiras a crimes..." (p. 5), a despeito dos benefícios que elas traziam para as parturientes.

Por outro lado, Porter (1997) $)^{4}$ argumentou que o charlatanismo inglês era apenas uma forma de sobrevivência dos indivíduos que o praticavam, e que a história mostrou, por exemplo, as dificuldades de estabelecimento de médicos diplomados, pois estes, em geral, 'concorriam' com os charlatães, considerados terapeutas populares mais ‘capazes' do que os médicos. Pimenta (2004), nesta mesma linha de raciocínio, considera que o uso do termo 'charlatão' “...como categoria analítica não ajuda a esclarecer algumas questões, como as semelhanças e as diferenças entre

\footnotetext{
${ }^{4}$ Citado em A linguagem do charlatanismo na Inglaterra. In: História social da linguagem. Porter, R. \& Burke, P., p. 83-90, 1997. Disponível em: http://books.google.com/books?id=3HgroJYbegUC\&pg=PP1\&dq=hist\%C3\%B3ria+social+da+linguag em\&cd=4\#v=onepage \&q=\&f=false. Acesso em 26-01-2010.
} 
muitos médicos oficializados e terapeutas não-autorizados; e - igualmente importante - a diversidade entre os próprios médicos e entre os próprios terapeutas populares." (p. 78). Acrescenta ainda que o termo “charlatão' possui “carga pejorativa” (p. 78) e dá a impressão de "denegrir a imagem de seus concorrentes" (p. 78). A mesma autora discutiu a dificuldade em se classificar os diversos tipos de terapeutas populares citados nos documentos do Arquivo Nacional no período do Império. Analisa que os documentos não causavam confusão somente entre “....médicos autorizados e terapeutas não-autorizados..." (p. 69), mas também entre os próprios terapeutas populares, que se confundiam entre aqueles que possuíam uma classificação legal (por ex., de parteiro, curandeiro, sangrador etc.) e aqueles que não possuíam uma classificação perante a lei, mas que atuavam como práticos populares. É possível que o termo 'charlatão' tenha ganhado força nos discursos dos profissionais de saúde, conforme veremos ao longo deste estudo, após o processo de institucionalização das profissões de saúde. Segundo Giumbelli (1997), era preciso deslegitimar os ofícios de pessoas não-habilitadas a exercer as práticas médicas para legitimar as habilidades dos profissionais de saúde que cresciam dentro de uma corporação, a exemplo dos médicos, conforme analisaremos no decorrer da pesquisa. Isso demonstrou as peculiaridades dentro da definição de 'terapeuta popular', e notamos que a particularidade de cada documento, de cada caso, requisitaria a separação detalhada do estudo em cada tipo de terapeuta popular, o que fugiria do objeto principal de nossa análise.

Ao lado das pessoas que fazem as práticas populares estão os tipos de substâncias utilizadas. Este estudo privilegiou o uso de medicamentos na forma de pílulas, pomadas e soluções, em detrimento dos outros tipos de compostos utilizados nas artes de cura populares, como os chás, as ervas, as infusões, as rezas, as magias. Embora exemplifiquemos mais adiante algumas destas formas de cura utilizadas, enfatizamos que a busca documental baseou-se na procura por indícios de terapia popular com medicamentos. ${ }^{5}$

\footnotetext{
$5 \mathrm{Na}$ definição atual, a automedicação pode ser executada por quaisquer pessoas, incluindo profissionais de saúde, que se utilizam de quaisquer tipos de substâncias (comprimidos, chás etc.) ou formas de cura (rezas, magias etc.). Consultar: Courtenay, M. Patients' attitudes towards, and information needs in relation to, nurse prescribing in rheumatology. J Clin Nurs., vol. 17, n. 2, p. 26673, Jan 2008; Purssell e col. Treatment of fever and over-the-counter medicines. Arch Dis Child., vol. 92, n. 10, p. 900-1, out 2007; Lopes, N. M. Automedicação: algumas reflexões sociológicas. Sociologia, problemas e práticas, n. 37, p. 141-165, 2001. Paulo \& Zanini. Automedicação no Brasil. Rev. Ass. Med. Bras., vol. 34, p. 69-75, 1988.
} 
Considerando nossa justificativa para a escolha pelo termo 'terapia popular', algumas perguntas conduziram nosso trabalho, na tentativa de compreender as alterações vivenciadas nas práticas de cura populares: como ela se modificou ao longo do tempo? De que maneira médicos e farmacêuticos responderam às regulamentações frente às práticas de cura populares? Como médicos e farmacêuticos transformaramse em autoridades de saúde a partir das modificações legislativas que influenciaram na terapia popular? Quais foram seus interesses profissionais que contribuíram para o controle do exercício profissional de terapeutas populares e do uso de medicamentos?

Com base nestas questões, tentamos buscar algumas evidências históricas na área de saúde conectadas ao caminho trilhado por médicos e farmacêuticos ao longo do tempo, seus motivos para desejarem a regulamentação das práticas alternativas de cura. As evidências funcionaram como 'acessórios' para a compreensão do que foi, e ainda é, a arte de cura popular, bem como seu papel frente às decisões governamentais.

Em uma época em que questões de higiene e de saúde eram pauta nos debates governamentais, concomitante ao desenvolvimento urbano e comercial em alguns países, foram sentidas novas conformações para o campo da medicina e da farmácia. Desta forma, pretendeu-se conduzir uma análise histórica comparativa, almejando compreender alguns dos motivos que levaram ao controle das práticas de cura populares no estado de São Paulo e na Inglaterra por meio de investigação do papel de médicos e farmacêuticos. A tese central do trabalho é que não se pode compreender o lugar da terapia popular na sociedade moderna sem entender o lugar de médicos e farmacêuticos nessa mesma sociedade. Assim, pretendemos ilustrar, por meio dos casos no estado de São Paulo e na Inglaterra, como foi a trajetória de estabelecimento do controle da terapia popular nessas sociedades a partir das regulamentações e lutas desses profissionais de saúde. O recorte temporal histórico determinado na Inglaterra foi de 1815-1858; no estado de São Paulo, de 1892-1930, período que faz parte da Primeira República Brasileira ${ }^{6}$.

Antes de começarmos a investigação histórica de fato, destacamos alguns fatos importantes relacionados ao desenvolvimento das profissões de médico e de

\footnotetext{
${ }^{6}$ Segundo Fausto (2004), a Primeira República também é denominada de República oligárquica, República dos "coronéis", República do "café-com-leite", República Velha. Para leitura sobre a Primeira República, consultar: A Primeira República (1889-1930). In: História do Brasil. São Paulo: Edusp, p. 243-328. Justificamos a seleção dos períodos de estudo no estado de São Paulo e na Inglaterra no capítulo "Metodologia".
} 
farmacêutico tanto em São Paulo como na Inglaterra mostrados pela historiografia. Iniciamos apontando alguns antecedentes no Brasil até 1892, data de estabelecimento da nova legislação sanitária no estado de São Paulo, nosso ponto inicial de análise aqui; a seguir, ressaltamos algumas das principais características da área farmacêutica no Brasil e também dos profissionais médicos em São Paulo. Uma observação importante no campo da farmácia é digna de nota aqui: contemplamos o país como um todo dada a escassez de estudos na área farmacêutica que retratassem somente o estado de São Paulo, e neste sentido, consideramos relevante mostrar como se encontrava o país àquela época na área de farmácia para auxiliar na compreensão em São Paulo quando do início da investigação histórica propriamente dita.

$\mathrm{Na}$ seqüência, contextualizamos alguns fatores de saúde na Inglaterra envolvidos no Ato Médico de 1815, data determinada neste estudo para iniciar a análise na Inglaterra. A seguir, abordamos os principais estudos presentes na historiografia inglesa sobre médicos e farmacêuticos do século XIX. Uma outra nota importante também se faz aqui quando referenciamos estes médicos e farmacêuticos na Inglaterra: consideramos a análise de outros profissionais de saúde, além de médicos e farmacêuticos, como os apotecários, cirurgiões, químicos e droguistas, dada a conexão de suas trajetórias profissionais com farmacêuticos e médicos ingleses.

$\mathrm{Na}$ Inglaterra, médicos, farmacêuticos, cirurgiões, apotecários, químicos e droguistas estiveram envolvidos no que os autores ingleses chamaram de reforma médica, que precedeu a reforma sanitária; ao passo que em São Paulo, algumas mudanças legislativas no exercício profissional de médicos e de farmacêuticos também aconteceram quando da organização do serviço sanitário em 1892. Tais modificações estavam inseridas no escopo legislativo da reforma sanitária de 1892. Ressalta-se aqui a investigação das reformas legislativas em saúde como ponto importante para compreender o papel de todos estes profissionais de saúde nas mudanças da terapia popular, tanto na Inglaterra como no estado de São Paulo, à medida que foram estas novas regulamentações que contribuíram para as transformações nas profissões de saúde.

Alguns antecedentes na saúde brasileira até a nova legislação sanitária de 1892 em $\underline{\text { São Paulo }}$ 
No Brasil, o uso de medicamentos caseiros, as práticas de rituais e o exercício de terapeutas populares foram atividades de saúde bastante utilizadas, mas por meio de uma mistura dos saberes indígena, negro e europeu. O uso de substâncias populares para curar doenças, por exemplo, já existia antes de chegar a influência portuguesa em nosso território: índios misturaram seus conhecimentos sobre remédios e doenças, lançando mão de substâncias de origem animal ou vegetal para curar seus problemas de saúde (Marques, 1999; Figueiredo, 1999; Ribeiro, 1997). As mezinhas ${ }^{7}$ eram elaboradas a partir de partes internas e externas de animais como o gambá, a anta, as cobras, a preguiça (Holanda, 1957). Em adição, a importância da medicina dos excretos na cura de doenças fazia parte do repertório de terapias utilizadas, como o uso da urina para curar moléstias relacionadas à pele, ao coração e a problemas gestacionais (Andrade, 1939). Estas mezinhas eram bastante utilizadas em Portugal e incorporaram-se aqui ao longo do tempo.

De fato, Portugal influenciou em diversos ramos de atuação durante a colonização da América Portuguesa. A instalação dos jesuítas também contribuiu para o exercício da terapia popular. Eram procedentes da Companhia de Jesus formada em Portugal no ano de 1540, com a missão de catequizar e educar os índios. Uma das funções destes jesuítas era a de tratar dos males de saúde da população, especialmente das epidemias de sarampo, varíola, disenteria, malária e febre amarela; assim, exerceram muitos ofícios relacionados à área de saúde: curaram doenças, descobriram ervas e plantas úteis no tratamento das enfermidades, fundaram hospitais, criaram boticas, exerceram os papéis de sangradores e barbeiros, em conjunto com a propagação da fé cristã (Calainho, 2005). Na mistura do conhecimento destes jesuítas mais as sabedorias indígenas e negras, caracterizou-se, assim, a saúde e a doença do período colonial (Marques, 1999).

Com a crise do sistema colonial, foram expulsos de Portugal e de seus domínios, além de haver interrupção do processo de ensino aos nativos (Fausto, 2004). Perdia-se, assim, esta contribuição médica dos jesuítas, que tentavam controlar as taxas elevadas de morbidade e mortalidade ocasionadas pelas doenças pestilenciais. Além deles, instituições filantrópicas e beneficentes, mais os terapeutas populares, cuidavam da população doente. A preocupação maior das autoridades locais era a de

\footnotetext{
${ }^{7}$ Do latim medecina, significa remédio caseiro. Em: Henrique Carneiro. Filtros, mezinhas e triacas: as drogas no mundo moderno, Xamã Editora, São Paulo, 1994.
} 
controlar a precariedade sanitária do espaço urbano que piorava as doenças (Costa, $1985)$.

Para cuidar destes problemas de saúde, não havia ainda uma profissão médica consolidada na saúde pública. A institucionalização corporativa das classes profissionais de saúde viria a acontecer, a passos lentos, somente a partir do final do século XIX em São Paulo (Teixeira, 2007; Mota, 2005). Embora tenha surgido no Brasil a primeira Sociedade de Medicina do Rio de Janeiro em 1829 (Teixeira, 2007), a formação da corporação médica como hoje conhecemos ainda estava em um processo bastante inicial. Assim, a pequena quantidade de médicos, em geral estudados em escolas estrangeiras, contribuía para os serviços de cura dos terapeutas populares: feiticeiros, sangradores, barbeiros e sacerdotes, que gozavam de certa autonomia para praticar seus rituais (Soares, 2001; Figueiredo, 1999; Pimenta, 1998). Existia, entretanto, certo tipo de controle sobre as práticas destes indivíduos, conforme atenta Costa (1999) ao analisar que o exercício do charlatanismo, praticado em todos os tempos, foi combatido pelo Estado de diversos países, “....apesar de ser incapaz de dar conta das obrigações de assistência à saúde, forçando a população a recorrer a quaisquer formas de curar.” (p. 37). Ademais, o exercício da medicina, bem como a organização da saúde e do saneamento, eram baseados na legislação portuguesa (Costa \& Rosenfeld, 2000).

Nestas condições, o principal órgão regulador foi a Fisicatura-mor, única instituição pública a controlar e a autorizar as práticas populares de cura. Foi instituída pelo governo português e atuou durante 20 anos no Brasil, de 1808 até 1828. O objetivo principal era o de regulamentar e fiscalizar as atividades relacionadas à saúde da população que eram praticadas por médicos, cirurgiões, boticários, barbeiros, sangradores, parteiras e curandeiros. Havia uma hierarquia onde barbeiros, sangradores, parteiras e curandeiros ocupavam as posições menos privilegiadas do órgão; médicos, cirurgiões e boticários, as posições de destaque. Apesar do controle, havia muito espaço para os terapeutas populares, pois a população confiava em suas técnicas (Pimenta, 1998).

Com a chegada da família real portuguesa para o país, a influência estrangeira de bens e serviços no país aumentou; houve também o início da saída de produtos para o mercado internacional. Com isso, houve maior necessidade de monitoramento sanitário para se evitar o espalhamento das doenças endêmicas e epidêmicas (Costa \& Rosenfeld, 2000). Segundo Marques \& Ibañez (2006), "Nos estudos históricos da 
política de saúde no Brasil, encontramos relacionada à vinda da corte portuguesa para o Rio de Janeiro, no início do século XIX, a ampliação de iniciativas com o caráter de vigilância sanitária, sempre sob a insígnia dual de sua origem, proteção da economia e da saúde.” (p. 4). É a partir da chegada da côrte portuguesa que a importância de se cuidar da saúde do povo e da própria família real ganharam novos contornos, com algumas tentativas de se combater as atividades de cura popular; mas isto seria reforçado somente após a proclamação da república.

Após a Independência, foi estabelecido um código sanitário que se destacou pelo controle de medicamentos e alimentos, hospitais e casas de saúde, e de zelar pelo exercício da medicina e da farmácia. Foi nesta época também que a fiscalização ao exercício do curandeirismo e do charlatanismo tomou caminhos mais evidentes (Machado, 1978 citado por Costa \& Rozenfeld, 2000).

Em meados do século XIX, as autoridades locais enfatizaram as deficiências dos cuidados de saúde da época por conta do aparecimento dos primeiros casos de febre amarela no Rio de Janeiro, reforçando a necessidade de novas medidas de saneamento e de saúde. Neste período, houve a consolidação da reforma dos serviços sanitários do Império e a instituição de um Conselho Superior de Saúde Pública (Costa, 1985). Somados a isso, ocorreram a organização das administrações estaduais e a implantação dos órgãos de vigilância sanitária em cada estado (Costa \& Rozenfeld, 2000). Ainda assim, o Estado de São Paulo, por exemplo, exterminou a febre amarela antes do Rio de Janeiro. Segundo Telarolli Junior (1996), o último caso desta doença foi registrado pelo serviço sanitário paulista em 1904. O período imperial terminou, portanto, marcado por precárias formas de assistência à saúde (Costa, 1985).

Com o advento da República, a União ficou responsável pelo controle de medicamentos, alimentos, doenças, hospitais, profissões de saúde, portos e fronteiras. Em meio aos problemas sanitários, aconteceram determinadas melhorias quanto à saúde da população e ao saneamento das cidades (Costa \& Rozenfeld, 2000).

Costa (1985) aponta que estas melhorias foram se estabelecendo desde 1889 e se estenderam até 1930. Argumenta que aconteceram dois momentos políticos importantes neste período: o primeiro, a ação de Oswaldo Cruz, “...marco inicial da introdução no país da organização de saúde fundada na bacteriologia, microbiologia e na generalização de medidas de imunização através das vacinas...” (p. 15); o segundo, o período de 1918-1924, com a criação do Departamento Nacional de Saúde Pública. 
$\mathrm{O}$ autor, entretanto, ressalta que "Embora tenha sido Oswaldo Cruz quem de fato introduziu a chamada medicina científica no Brasil, foi em São Paulo que primeiramente surgiram os empreendimentos de higiene pública visando a manutenção da força de trabalho.” (p. 41).

Assim, foi somente no final do século XIX que efetivamente se começou a pensar em alternativas mais sólidas para os problemas de saúde nas cidades, como o cuidado ao espaço urbano e às epidemias que pioravam a saúde da população. A intenção da reforma sanitária no país era não somente de combater tais doenças, mas também de criar uma nova administração de saúde pública para o Brasil e de desenvolver a pesquisa científica no país (Marques \& Cunha, 2006; Castro Santos, 2004). Conforme Ribeiro (2001) aponta, os institutos de ciências biológicas como o Bacteriológico, o Vacinogênico, o Butantã e o Biológico foram criados na Primeira República. O país recebia também influência de países europeus não somente na pesquisa científica (Kury, 2004), como em questões de saúde e de saneamento (Singer, 1978).

De acordo com Hochman (2006), "Trata-se de um período de crescimento de uma consciência entre as elites em relação aos graves problemas sanitários do país e de um sentimento geral de que o Estado nacional deveria assumir mais a responsabilidade pela saúde da população e salubridade do território.” (p. 40). Isto implicaria em aumentar as atribuições do Estado, “...restritas até então ao Distrito Federal e à defesa sanitária marítima" (p. 40).

A nova legislação sanitária de 1892 no estado de São Paulo emergiu em meio a um Brasil que passava por mudanças significativas em questões políticas, econômicas, sociais e culturais. O país apresentava o café como principal produto agrícola, cuja produção e comercialização, no período da Primeira República, elevouse consideravelmente, o que contribuiu para fortalecer a classe rural e o comércio. Além disso, a mão-de-obra do imigrante era atraída para o Brasil em virtude das péssimas condições que a Europa passava por conta da Primeira Guerra Mundial (Prado Júnior, 2008; Hochman, 2006). Cidades de São Paulo como Campinas e Santos foram bastante beneficiadas com a questão do saneamento das cidades, que visava garantir a saúde dos imigrantes e conseqüentemente a economia do café. Este desenvolvimento do espaço urbano levou ao aumento da população urbana (Costa, 1985). 
De fato, São Paulo adotou uma reforma sanitária que acabou se diferenciando dos demais estados do Brasil: realizou suas políticas de saúde concentrando suas forças em termos locais, independentemente da esfera federal, o que acabou por influenciar outras regiões do país (Hochman, 2006), a despeito das individualidades e peculiaridades regionais de cada local. Em 1891, foi criado o Serviço Sanitário no Estado; em 1892, a legislação sanitária; e já no 'auge' do movimento sanitário, ocorreu o fim do modelo tecnológico campanhista e policial. Surgia o modelo de educação sanitária, com o objetivo de orientar a população por meio de informações sobre as doenças e maneiras de cuidado com a saúde (Mota, 2005; Ribeiro, 2001).

O movimento sanitarista criou, portanto, bases para a implantação de políticas públicas de saúde e de saneamento nas regiões do Brasil. Uma das questões que ganharam importância com a reforma sanitária foram as ações em vigilância sanitária em algumas unidades da federação, como em São Paulo, com o controle de medicamentos e profissões (Costa \& Rozenfeld, 2000). É a partir da nova legislação sanitária em 1892 que as regulamentações voltadas para o exercício de profissionais de saúde, bem como de suas atribuições em saúde na sociedade, ganham novo enfoque, com conseqüências para as práticas populares de cura buscadas pela população paulista da época. Neste ponto encontra-se o elemento principal de nossa análise no estado de São Paulo: a compreensão das mudanças ocorridas na terapia popular foi baseada na investigação do lugar de alguns profissionais de saúde a partir das reformas legislativas em saúde. Por este motivo, vejamos alguns fatos históricos contemplados na historiografia atual referentes às normatizações dos profissionais de saúde, que levaram à regulamentação de suas atividades e, conseqüentemente, de alterações nos rumos das artes de cura populares.

\section{Alguns fatores ligados à profissão farmacêutica no Brasil}

A formação do profissional farmacêutico esteve conectada com as atividades que o boticário exercia como manipulador de fórmulas. O boticário foi personagem importante que atuou nesta função, oficialmente, até a lei de 3 de outubro de 1832 , quando se estabeleceu que nenhuma pessoa poderia exercer estes ofícios sem o diploma de farmacêutico (Edler, 2006; Marques, 1999).

Mott \& Alves (2006) abordam a profissionalização da área farmacêutica após 1892. Destacam que entre os anos de 1892 e 1919, 1514 farmacêuticos se registraram no Serviço Sanitário do estado de São Paulo. Esse é um aspecto importante sobre a 
regulamentação farmacêutica e que teve conseqüências para a terapia popular. Segundo Marques (1999), no período imperial havia um sem-número de indivíduos sem qualificação em farmácia que trabalhavam nas artes de formular. A regulamentação farmacêutica na Primeira República traria mudanças nas normas para se manipular medicamentos por pessoas sem qualificação com o processo de profissionalização farmacêutica. Somado a isso, o incentivo à criação das escolas de farmácia acontecia no período da Primeira República para dar mais base técnica em farmácia para os futuros farmacêuticos.

De fato, a profissionalização e a institucionalização da profissão também foram marcas importantes durante a Primeira República. O primeiro ensino em farmácia oficial, atrelado aos cursos de medicina, ocorreu em 1832, com as escolas de medicina do Rio de Janeiro e da Bahia. A primeira escola de farmácia independente surgiu somente em 1839, a Escola de Farmácia de Ouro Preto (Santos, 1999).

Em São Paulo, a criação de escolas de farmácia também foi relevante para influenciar o ensino farmacêutico. Havia duas escolas na capital, a Escola Livre de Farmácia, criada em 1898, e a escola da Universidade de São Paulo ${ }^{8}$, criada em 1911; no interior de São Paulo, havia oito escolas: em Pindamonhangaba, criada em 1913, São Carlos, 1914, Piracicaba, 1915, Mococa, 1916, Itapetininga, 1921, Jaboticabal e Araraquara, 1923, Ribeirão Preto, 1924 (Mott \& Alves, 2006). Neste sentido, mudanças seriam observadas para todas as pessoas envolvidas nas artes de fazer fórmulas, seja com diploma de farmacêutico, seja sem diploma. Porém, não há estudos sobre como esse processo de profissionalização em farmácia no estado de São Paulo impactou na procura e na regulamentação da terapia popular.

Também não há investigações históricas sobre o relacionamento de farmacêuticos com a produção inicial de medicamentos na indústria em São Paulo no período da Primeira República. Isso também nos suscitou a investigação haja vista que o mercado de produtos farmacêuticos industrializados traria uma nova

\footnotetext{
${ }^{8}$ Apesar das autoras utilizarem o termo "Universidade de São Paulo" em seu trabalho, acreditamos que as autoras denominam esta "Universidade de São Paulo" como sendo a "Universidade Livre de São Paulo", escola de caráter particular, citada também por Marinho (2006). É importante distinguir as denominações porque, de acordo com Marinho (2001), a atual Universidade de São Paulo (USP) só foi criada em 1934. Seu estudo baseou-se na criação da USP sob a influência norte-americana. Sobre a criação da "Universidade Livre de São Paulo", consultar: Trajetória da Faculdade de Medicina da Universidade de São Paulo: aspectos históricos da "Casa de Arnaldo". São Paulo: Faculdade de Medicina da Universidade de São Paulo, 2006. Sobre a USP, consultar: Norte-americanos no Brasil: uma história da Fundação Rockefeller na Universidade de São Paulo (1934-1952). Campinas: Editora Autores Associados Ltda., 2001.
} 
conformação para as práticas de fazer, de usar e de vender medicamentos. Segundo Edler (2006), predominava a busca por medicamentos caseiros pela população do período imperial.

Campos (1966) argumenta que a formação dessas indústrias foi resultado da Revolução Industrial do século XIX, permitindo a transição das atividades artesanais de estabelecimentos simples como as farmácias para “...as características de produção em série, padronizada, jogando com processos largamente mecanizados.” (p. 86). Ressalta ainda que a indústria “...não visou mais que a multiplicação da fórmula na unidade de tempo e de pessoal habilitado." (p. 86). Segundo Campos, tal multiplicação era resultado do crescimento populacional, e o desenvolvimento inicial da indústria amenizou o problema da carência de farmacêuticos para atender a demanda populacional da época, pois atuavam, em sua maior parte, em estabelecimentos menores, como as farmácias.

Desde o final do século XIX até 1930 havia o predomínio destes pequenos estabelecimentos no país, ou ainda das boticas: produziam fórmulas à base de substâncias animais ou vegetais, ou outros tipos de compostos químicos, mas todos de natureza bastante simples e artesanal (Bermudez, 1995; Giovanni, 1980). No intermédio deste período é que começam a surgir, em paralelo às farmácias e às boticas, alguns laboratórios farmacêuticos nacionais que produziam medicamentos, principalmente em São Paulo, Rio de Janeiro e Distrito Federal (Giovanni, 1980).

Os profissionais farmacêuticos foram perdendo espaço nos tradicionais laboratórios caseiros para serem substituídos pelas indústrias (Santos, 1999). Consequentemente, aquelas boticas e farmácias, que funcionavam como estabelecimentos de prescrição e venda de medicamentos, começavam a ser substituídas pelas empresas farmacêuticas. Segundo Edler (2006), havia uma consonância entre prescrição, manipulação e cura popular: "As boticas ou farmácias, mesmo nos centros urbanos da época, como Rio de Janeiro, São Paulo, Salvador, Ouro Preto e Recife, acabavam funcionando como locais de assistência médica e farmacêutica, incluindo a prescrição e manipulação dos medicamentos e, provavelmente, a aplicação de procedimentos usuais na época.” (p. 67). Assim, aquela característica 'caseira e familiar' do cuidado foi se perdendo para criar um espaço voltado para o cuidado terapêutico baseado na produção de medicamentos em série e mais rápida. 
Este crescimento industrial esteve conectado ao combate das doenças infecciosas, às práticas sanitárias de prevenção e às instituições de pesquisa básica (Ribeiro, 2001; Bermudez, 1995). A produção de medicamentos, especialmente de vacinas e soros para o combate às doenças e o cuidado ao espaço agropecuário, ficava nas mãos de órgãos públicos como os Institutos Butantan, Bacteriológico e Biológico. Alguns pesquisadores destes institutos migraram de suas instituições públicas de origem para as indústrias farmacêuticas nacionais; ou ainda, 'treinaram' profissionais da área da saúde para atuarem nestas empresas farmacêuticas: Vital Brazil, por exemplo, que trabalhava no Instituto Butantan, deixou esta instituição em 1919 para abrir sua própria firma, o Instituto Vital Brazil, e com ele levou alguns cientistas. Outro caso expressivo é a implantação do Instituto Pinheiros - Produtos terapêuticos S.A., que foi uma empresa privada nacional criada por médicos treinados por pesquisadores do Instituto Butantan em 1928 (Ribeiro, 2001).

Ibañez e colaboradores (2006) ressaltam que houve muita discordância entre cientistas e autoridades políticas naquele período sobre essas 'migrações', mas acrescentam que "Outros autores que discutem a formação da indústria farmacêutica nacional em São Paulo vêem positivamente, neste período, a interligação de pesquisadores dos institutos públicos com a nascente empresa privada. Esse tema foi, na década de 30, um divisor de águas e de certa forma, forjou uma visão do papel do Estado não como regulador e disciplinador destes espaços, mas como produtor de produtos que visassem suprir necessidades da demanda sanitária.” (p. 85).

Assim, farmacêuticos, atuando nestas indústrias, estavam ligados ao controle das doenças por meio de sua atuação na produção de medicamentos: eram os profissionais responsáveis pelos cuidados de assistência medicamentosa - conheciam as drogas, as matérias-primas vegetais, entendiam de farmacologia, física, química e um pouco de medicina (Campos, 1959). Esse jogo entre farmacêuticos e indústria farmacêutica fizeram da área em farmácia um campo cada vez mais técnico, deixando a farmácia 'doméstica' de lado, e foram as consequências dessa mudança que investigamos nas alterações das artes populares de fazer, usar e vender medicamentos.

Neste contexto, a indústria, e consequentemente, o comércio expandiam-se, especialmente pela “...exportação e pelo declínio das importações de mercadorias dos tradicionais países fornecedores...” ocasionadas pela Primeira Guerra Mundial: eram 13.336 estabelecimentos industriais, com destaque para a indústria de alimentos 
(Prado Júnior, 1981 citado por Costa \& Rozenfeld, 2000) e também de compostos químico-farmacêuticos (Costa \& Rozenfeld, 2000).

As primeiras empresas farmacêuticas começaram a entrar no espaço paulista principalmente após a década de 20 (Ribeiro, 1997). Segundo Campos (1966), “A guerra de 1914-1918 foi decisiva para o incremento da indústria farmacêutica séria, no Brasil, dadas as proibições feitas pelos países europeus, nossos fornecedores, da exportação de numerosas drogas essenciais à fabricação de medicamentos, tais como os ácidos salicílico e acetil-salicílico, o clorofórmio, hidróxido de sódio, cloreto de sódio, ácido di-etil-barbitúrico, novocaína, fenol, acetona, anilina, etc. Privado de suas fontes habituais, o parque industrial farmacêutico brasileiro realizou um esfôrço magnífico e, ao término da guerra, sua situação era de tendência a uma digna autonomia." (p. 87). Em adição, Cunha (2007) atenta que "Esse arranco industrialista foi paralelo e, em parte, resultado da penetração de empresas norte-americanas no Brasil, propiciada pela admiração dos dirigentes da nova república pelos Estados Unidos da América e pela posição hegemônica desse país no conjunto da economia mundial, consolidada após o fim da Primeira Guerra Mundial.” (p. 142).

Ribeiro (2001) afirma que havia um interesse 'capitalista' da elite paulista muito mais do que um interesse 'agrarista', em decorrência das oligarquias do café, ressaltando que esta mesma elite pretendia dominar o país nos campos intelectual e científico, e não somente atuar na política e na economia do Brasil. Ribeiro conclui que as políticas voltadas para a melhoria da saúde pública contribuíram, indiretamente, para formar a indústria farmacêutica nacional: a despeito das políticas em curso no período terem sido construídas para controlar as doenças, acabaram também por incentivar o processo de industrialização da farmácia no país.

Ao mesmo tempo em que a indústria se desenvolvia, havia uma resistência da população brasileira em lidar com estas novas tecnologias farmacêuticas. Segundo Goodwin Junior (2004), sua análise de anúncios publicados em jornais de Diamantina, MG, no período de 1900-1914 revelou que havia uma grande quantidade de anúncios ligados ao item "farmácia/boticário": propagandas de medicamentos vegetarianos e à base de ervas, representando quase $33 \%$ do total de anúncios avaliados. Ainda, pelo volume de anúncios encontrados, o autor relata que “...ainda havia muito mais espaço para a automedicação e os remédios populares do que demanda por clínicos regulares" (p. 7). Souza (2005) também atenta para o uso de "...folhas e receitas caseiras..." no combate à gripe espanhola de 1918 em Salvador. 
Desta forma, a profissionalização do farmacêutico, atrelada ao desenvolvimento da industrialização na área, são importantes porque trouxeram consequências importantes para a terapia popular, seja diminuindo ou mantendo esta prática. O farmacêutico teria papel importante nas transformações da saúde, e envolveria-se com outros profissionais, como os médicos, para seguir sua trajetória ao longo das primeiras décadas do século XX. Nestas condições, do profissional farmacêutico dependia o profissional médico para trabalhar em conjunto: enquanto este diagnosticava as doenças e indicava terapias, aquele era responsável por assistir aos tratamentos escolhidos pelos médicos. A reorganização em São Paulo da classe médica trouxe consequências para as práticas de cura populares, investigação ainda pouco estudada na historiografia de São Paulo. É da classe dos médicos, portanto, que falaremos no próximo item.

\section{Médicos em São Paulo}

As novas funções dos profissionais médicos no estado de São Paulo decorriam da reorganização de seu espaço na Primeira República frente às novas necessidades do país. Atuaram em questões sanitárias e de saúde com o intuito de melhorar o quadro epidêmico, a falta de higiene, de saneamento e da própria indefinição quanto às suas funções como médicos. A classe médica era readequada às carências sociais e de saúde do estado, ganhando impulso para desenvolver suas atividades e, assim, caminhando para o processo de estabelecimento de sua profissão de forma diferenciada (Mota, 2005; Silva, 2003; Costa, 1985). Neste contexto, a profissão médica estava incluída nas mudanças da nova legislação sanitária, assim como a profissão dos farmacêuticos. Isso trouxe reflexos importantes para as pessoas que buscavam os terapeutas populares, modificando seus rumos.

Iyda (1993) relata que neste período as doenças eram tratadas mais em família ou por meio das entidades filantrópicas, e que havia pouca intervenção da esfera pública nos cuidados com a saúde da população. Segundo Silva (2003), alguns relatórios da Santa Casa de Misericórdia da cidade de São Paulo em período anterior ao século XIX mostraram o predomínio principalmente das irmãs de caridade, enfermeiras e dos médicos. No entanto, estes últimos não exerciam adequadamente os exames necessários para diagnosticar e curar as enfermidades dos doentes, atuando de maneira superficial e insuficiente. O conhecimento médico acerca de doenças e tratamentos não era adequado o suficiente para atender às necessidades dos doentes. 
Somado a isso, a população tinha crença maior na capacidade de cura de curandeiros do que na cura por estes profissionais, já no despertar do século XIX (Pimenta, 1998). $\mathrm{Na}$ realidade, até o final do século XIX, havia uma oposição entre as medicinas popular e científica, onde os médicos tentavam lidar com o exercício das artes de cura populares. Segundo Chalhoub e colaboradores (2003), tais artes eram mais confiáveis do que o trabalho dos médicos.

Com a reforma sanitária a partir da nova legislação de 1892, outras conformações técnicas, sociais e políticas emergiram para os profissionais. $\mathrm{O}$ profissional passou a ser visto de forma mais positiva, com a diminuição da atividade de charlatães e benzedeiros. A partir do processo de implantação dos serviços sanitários em São Paulo em fins do século XIX, uma quantidade maior de profissionais foi necessária para atender à demanda populacional (Silva, 2003). Schraiber (1997), analisando o depoimento de alguns médicos que atuaram no período republicano em São Paulo, destaca esse crescimento de importância do médico nas primeiras décadas do século XX: "Os partos eram feitos a domicílio por comadronas. Não havia muitas pessoas formadas, porque foi a Maternidade São Paulo que fez a escola de parteiras, por volta de 1913. De maneira que eram umas pessoas adaptadas, por assim dizer, ao serviço, e controladas até certo ponto por médicos, mas não eram formadas.” (p. 349). Médicos já eram os profissionais requeridos para sanar os cuidados populares de parteiras, por exemplo.

Follis (2003) atenta que os médicos do início do século XX, junto com engenheiros e bacharéis em direito, eram considerados "homens da ciência", com "saber especializado moderno", ocupando “...cargos públicos relevantes na administração municipal desses centros urbanos em transformação.” (p. 74).

A partir do final do século XIX, um aspecto importante sobre o crescimento da normatização médica e que teve consequências para as práticas populares foi, segundo Silva (2003), São Paulo mostrando a profissão por meio de discussões, debates, divulgações na imprensa, do surgimento das primeiras publicações médicas. O estabelecimento da Sociedade de Medicina e Cirurgia de São Paulo em 1895, criada por médicos, também foi um fator que contribuiu para a legitimação médica. Foi uma entidade com fins científicos e profissionais, atuando na construção da Policlínica de São Paulo, na colaboração da elaboração dessas revistas científicas e no reforço pela necessidade da criação do ensino médico em São Paulo. Personalidades de destaque 
no período, como os Drs. Arnaldo Vieira de Carvalho e Luís Pereira Barreto foram membros dessa Sociedade (Marinho, 2006).

Mota (2005) ressalta que havia a idéia de se construir uma classe "poderosa" que dominaria "higienicamente" a população do estado de São Paulo, e isso seria conseguido, por exemplo, por meio da criação de uma faculdade de medicina na cidade. (p. 169). Já havia uma escola privada de medicina, que funcionou entre $1911 \mathrm{e}$ 1917: vinculada à Escola Livre de Pharmacia, esta última também de iniciativa particular, fazia parte da Escola Livre de São Paulo (Marinho, 2006). A escola médica acabava por elevar a bagagem técnica de médicos, elevando o ensino em medicina, e com a recriação da Faculdade de Medicina e Cirurgia em $1912^{9}$ em São Paulo, a profissão médica ia, aos poucos, alcançando seus objetivos (Marinho, 2006; Mota, 2005). No Brasil, já existiam escolas médicas antes desta fundação em São Paulo: em Salvador e no Rio de Janeiro, fundadas em 1832 (Barreto \& Aras, 2003; Scliar, 1987). Segundo Marinho (2006), disciplinas como anatomia, fisiologia e microbiologia faziam parte da nova grade curricular dos estudantes de medicina: o objetivo do diretor era de criar uma instituição com característica não somente teórica, mas também experimental, unindo teoria e clínica para dar um cunho mais 'científico' à medicina de São Paulo. A criação do ensino médico em São Paulo é outro aspecto importante que contribuiu para reafirmar a profissão de médico, e que também trouxe consequências para a medicina popular praticada na Primeira República. Neste sentido, a investigação desse posicionamento 'vantajoso' dos médicos na saúde do estado de São Paulo, nos diversos fatos mencionados, foi outra lacuna que tentamos preencher, relacionando-os às mudanças nas práticas populares.

\footnotetext{
${ }^{9}$ Em 1891, houve uma primeira tentativa de se criar uma faculdade de medicina na cidade de São Paulo, quando o presidente do estado de São Paulo assinou o decreto n. 19 de 24 de novembro de 1891. No entanto, questões políticas impediram a formação desta escola, e foi somente em 19 de dezembro de 1912 que se estabeleceu a lei n. 1.357, criando a Faculdade de Medicina e Cirurgia de São Paulo. O decreto n. 2.344 de 31 de janeiro de 1913 nomeou para a direção dessa escola o médico Arnaldo Vieira de Carvalho, e uma de suas principais preocupações era a de criar um caráter mais científico para a escola, voltado para a pesquisa e a parte laboratorial. Desejava abolir a característica predominante no período de aulas teóricas e parte clínica. Assim, isso foi estimulado pelas relações iniciais dos dirigentes da faculdade de medicina com a Fundação Rockefeller a partir de 1916, quando uma das comissões desta fundação vieram ao Brasil com o intuito de buscar centros de ensino em medicina. Foi a partir de 1918 que as relações entre a Fundação Rockefeller e a Faculdade de Medicina e Cirurgia de São Paulo fortaleceram-se, e neste período, a pesquisa e o ensino em medicina já apresentavam características importantes. Consultar: Marinho, M.G.S.M. da C. Elites em negociação: breve história dos acordos entre a Fundação Rockefeller e a Faculdade de Medicina de São Paulo (1916-1931). Bragança Paulista, SP: Editora Universitária São Francisco, p. 11- 66, 2003. Trajetória da Faculdade de Medicina da Universidade de São Paulo: aspectos históricos da "Casa de Arnaldo". São Paulo: Faculdade de Medicina da Universidade de São Paulo, p. 19-74, 2006.
} 
Conforme mostram Mott e colaboradores (2008), o serviço sanitário de São Paulo registrou 221 médicos brasileiros inscritos no serviço entre 1893 e 1902, de um total de 268 médicos (p. 856-857). Segundo Almeida (2006), eram personalidades importantes que começavam a se destacar não somente em São Paulo, mas também internacionalmente. A autora fez uma análise das redes médico-científicas que existiram nos diversos congressos médicos latino-americanos durante o início do século XX: profissionais importantes como Clemente Ferreira ${ }^{10}$ e periódicos como a Revista Medica de S. Paulo ${ }^{11}$ destacavam-se na América Latina.

Essa rede científica que se formava na classe médica, com consequências para as artes de cura populares, foi outro aspecto que tentamos investigar, haja visto que estes profissionais demonstravam grande interesse na formação da corporação médica, que seria alimentada pelo desenvolvimento da ciência médica. Esta institucionalização da classe médica traria reflexos diretos na saúde pública. De acordo com Teixeira (2004), os embates sobre as febres paulistas que existiram entre a classe médica nas sessões da Sociedade de Medicina e Cirurgia de São Paulo entre 1896 e 1897 demonstraram seus anseios pessoais em detrimento do benefício público. Exemplar desse aspecto é a disputa sobre a denominação científica da 'febre palustre', que passou a ser classificada como 'febre tifóide'; tal processo de mudança criou um desconforto grande entre médicos que já possuíam suas publicações sobre febre palustre como 'corretas', e médicos que usavam os avanços da bacteriologia como nova maneira de fazer a ciência. Segundo este autor, "Durante mais de um ano eles se digladiaram em intermináveis discussões sobre o tema na Sociedade de Medicina, avançando e recuando em suas posições - muito mais pelo poderio da autoridade científica dos defensores de cada opinião nos diversos momentos do que pelo surgimento de novas evidências que parecessem jogar por terra as opiniões adversárias." (p. 43).

\footnotetext{
${ }^{10}$ Mota (2005) destacou em seu trabalho que Clemente Ferreira foi um médico que coordenou o projeto contra a propagação da tuberculose, denominado de "Liga Paulista contra a Tuberculose" a partir de 1900. Em 1904, seria fundado o dispensário "Clemente Ferreira". Para leitura sobre o tema, consultar: Um Projeto na Metrópole: A Liga Paulista contra a Tuberculose”. In: Tropeços da Medicina Bandeirante: Medicina Paulista entre 1892-1920. São Paulo: Edusp, p. 125-165, 2005.

${ }^{11}$ Segundo Silva (2003), a Revista Medica de S. Paulo foi a segunda publicação médica paulista surgida em 1898. Consultar: O início do periodismo médico paulista na construção de uma medicina modernizada. In: O mundo transformado em laboratório: ensino médico e produção de conhecimento em São Paulo de 1891 a 1933. Tese de doutorado - Faculdade de Filosofia, Letras e Ciências Humanas da Universidade de São Paulo, p. 89-129, 2003.
} 
Este interesse corporativo dos profissionais médicos também foi reforçado nas questões referentes às causas da febre amarela no Brasil. Benchimol $(2000,1995)$ estuda, em dois trabalhos, essa questão da teoria dos miasmas. No primeiro, analisa como se deu a instituição da microbiologia no país e suas implicações para a saúde pública: havia muitas controvérsias sobre o germe causador da febre amarela, onde médicos argumentavam que a doença era "...produto de miasmas, de algum outro envenenamento químico ou ainda de fermentos inanimados..." (2000, p. 269); no segundo estudo (1995), trata da atuação de Domingos José Freire e sua descoberta da vacina e do micróbio da febre amarela, ressaltando que Freire possuía adversários como inventores de remédios e médicos clínicos, que eram contra seus tratamentos 'científicos'.

Almeida (2000) aprofunda mais seus estudos sobre as disputas entre os estudiosos da febre amarela no país, e destaca Emílio Ribas. A autora mostra que este médico, na direção do serviço sanitário do estado de São Paulo em 1898, debruçou-se sobre os estudos referentes aos modos de transmissão da febre amarela, creditando seus esforços às teorias microbiológicas e bacteriológicas que começavam a emergir naquele período. Havia uma confluência de informações direcionadas para o agente causador, as formas de contágio da doença, e Emílio Ribas atribuía várias causas para a doença. Algumas delas eram ligadas ao fato da picada do mosquito ser a causadora da doença, associada ao fato da água estar contaminada por larvas do mosquito causador. Isso não somente minaria a 'crença' de outros cientistas de que os miasmas $^{12}$ eram a causa das doenças, como também mexia em questões de saneamento urbano importantes do período, como as necessidades de melhora do tratamento de água, esgoto etc.

\section{Alguns fatores de saúde relacionados ao Ato Médico de 1815 na Inglaterra}

Da mesma forma que em São Paulo, a Inglaterra teve uma série de fatos ligados às profissões de saúde que trouxeram consequiências importantes para as artes de cura populares. Por exemplo, lá também aconteceram as reformas médica e

\footnotetext{
${ }^{12}$ Sucintamente, esta teoria considerava o ar, a água e o solo contaminados como os elementos que contribuíam para espalhar as doenças. Havia uma relação entre corpos humanos e animais mortos com o meio ambiente, onde sua decomposição era a causa das doenças. Consultar: Thorsheim, P. Inventing Pollution. Coal, Smoke, and Culture in Britain since 1800. Ohio University Press: Athens, p. 10-18, 2006; Robbins, J. The Miasma. Epidemic and Panic in Nineteenth Century Ireland. Institute of Public Administration, p. 9-14, 1995; Rosen, G. A history of public health. Baltimore and London: The Johns Hopkins University Press, p. 26-56, 251-269, 1993.
} 
sanitária, que trouxeram novas regulamentações para diversos profissionais de saúde. Assim, foram nas lacunas dos fatos históricos relacionados aos papéis destes profissionais que tentamos encontrar as respostas para as modificações na terapia popular.

Porém, diferentemente de São Paulo, a Inglaterra teve sua reforma sanitária acontecendo depois do início da reforma médica. Houve a necessidade de se 'unir' as técnicas médicas já utilizadas, principalmente cirúrgicas, aos avanços da química e da física, evidenciados ao longo do século XVIII, por conta do processo industrial pelo qual passava o país. Unir os conhecimentos em anatomia e fisiologia, por exemplo, ao desenvolvimento laboratorial e à análise de dados experimentais tornariam a medicina uma prática mais 'completa' (Conrad, 1995).

Neste contexto, ao mesmo tempo em que estes conhecimentos traziam progresso para a Inglaterra, traziam também conflitos privados de profissionais de saúde, que disputavam um lugar de reconhecimento na saúde pública, frente às carências de saúde da população no período. Estes profissionais trabalharam principalmente para sanar a falta de cuidados encontrados nas workhouses do período industrial: funcionavam como 'médicos', mesmo não sendo legalmente reconhecidos, resolvendo problemas de doenças e de terapia com medicamentos (Holloway, 1966). De fato, o desenvolvimento da indústria têxtil, da máquina a vapor, a manufatura do ferro, a eletricidade modificaram o meio urbano, trazendo mudanças para questões como habitação, transporte, saúde e saneamento (Burns, 1966). Na realidade, os empregadores das fábricas deram-se conta de que um trabalhador gozando de boa saúde traria benefícios ao desenvolvimento do processo industrial (Thomas, 1997; Cooper, 1989).

Assim, um dos principais fatores que levavam a população inglesa à busca por estes profissionais 'populares' foram as epidemias, como as de febre tifóide e cólera, que prejudicavam o ambiente fabril (Holloway, 1966). O cólera começou a se disseminar na Grã-Bretanha após o contato dos soldados britânicos que chegaram da Índia em 1818. A partir deste momento, autoridades governamentais e de saúde iniciaram um movimento pelo controle dessa doença, especialmente em Londres, onde a epidemia foi pior. Assim, de 1830 em diante, um movimento por mudanças no saneamento em toda a Grã-Bretanha ganhou força, e foi com o Ato da Reforma de 1832 que, de fato, começou a trajetória da reforma sanitária na saúde pública inglesa (Cooper, 1989). Segundo Gladstone (1997), sua análise do relatório sobre mortalidade 
escrito por Edwin Chadwick, no período 1831-1839, evidenciou as más condições urbanas: a taxa de mortalidade foi de 26,6 por mil, comparada com 18,2 por mil no interior.

Foucault (2006) ressalta que a Inglaterra começou seu movimento pela reforma no saneamento voltada para a saúde do trabalhador fabril porque era preciso criar um controle médico dos pobres, e isto se deu com a Lei dos Pobres de 1834. O objetivo desta lei era o de dominar a “...saúde e o corpo das classes mais pobres...” (p. 97), para que essa “...intervenção médica...” (p. 95) na sociedade inglesa de antes da metade do século XIX funcionasse como uma “...assistência controlada...” (p. 95), de maneira que ajudasse tanto “...os mais pobres a satisfazer suas necessidades de saúde, sua pobreza não permitindo que o façam por si mesmos, quanto um controle pelo qual as classes ricas ou seus representantes no governo asseguram a saúde das classes pobres e, por conseguinte, a proteção das classes ricas. Um cordão sanitário autoritário é estendido no interior das cidades entre ricos e pobres: os pobres encontrando a possibilidade de se tratarem gratuitamente ou sem grande despesa e os ricos garantindo não serem vítimas de fenômenos epidêmicos originários da classe pobre." (p. 95).

Atenta ainda que há uma “...transposição, na legislação médica, do grande problema político da burguesia nesta época: a que preço, em que condições e como assegurar sua segurança política. A legislação médica contida na Lei dos pobres corresponde a esse preço.” (p. 95).

Desta forma, o envolvimento dos profissionais de saúde nestes aspectos sanitários na Inglaterra do século XIX mudaram as normas para o exercício destes profissionais, trazendo conseqüências importantes para, por exemplo, as funções 'médicas' dos terapeutas do povo procurados pela sociedade inglesa da época. Assim, o próximo item foi destinado a mostrar como era a posição destes profissionais na área de saúde durante o processo da reforma médica.

Os profissionais de saúde na Inglaterra

Palmegiano (1998) aponta a heterogeneidade de profissionais de saúde que foram importantes para lidar com os problemas de saúde no século XIX, envolvendose no controle das elevadas taxas de mortalidade, nos usos de medicamentos e na diagnose médica. Foram submetidos a novas normatizações em suas respectivas 
atividades, ao mesmo tempo em que possuíam suas liberdades de exercer as artes médicas da forma que lhes convinham.

Nestas condições, alguns profissionais atuaram na reforma sanitária iniciada a partir de 1830 com o intuito de combater as epidemias e as más condições de saneamento. Trabalharam também no controle da venda e do uso de drogas onde, segundo Berridge (1999), o consumo de drogas elevou-se no século XIX, especialmente por conta das overdoses. De acordo com Porter (1997), a Sociedade para o Estudo e a Cura da Intoxicação, fundada em 1884 pelo Dr. Norman Kerr, investigou os abusos de álcool, ópio, cocaína e hidrato de cloral na Inglaterra, reflexo das preocupações do início do século XIX. Esse controle de autoridades de saúde sobre as doenças e sobre o uso de medicamentos modificaram a forma como a população inglesa do século XIX procurava as práticas de cura alternativas, e foi este aspecto que tentamos compreender.

Uma das classes de profissionais mais envolvidas foram os médicos. Foram os profissionais de saúde que mais atuaram na reforma sanitária da Inglaterra. Segundo Stewart \& Jenkins (1969), atuaram no controle das mortalidades ocasionadas principalmente pelas epidemias do século XIX, como o tifo, a febre tifóide, o cólera, a tuberculose, a escarlatina e febres recorrentes, o sarampo, a diarréia e a catapora. Trabalharam, juntamente outros profissionais, nas preocupações em torno do suprimento de água, energia, habitação e o controle de alimentos e doenças. Apesar da pequena quantidade de doutores atuando nesta reforma, acabaram por exercer um papel central nas modificações das condições precárias da população. A maioria era composta de médicos administradores que tentaram resolver tais problemas (Hanley, 1999).

Os médicos são os mais antigos profissionais na saúde pública inglesa, desde que as profissões de saúde começaram a ser regulamentadas pelas autoridades parlamentares. Sua trajetória profissional foi marcada com a fundação do Colégio Royal de Médicos já em 1518. Mas somente no início do século XIX é que ganharam um destaque importante na saúde pública da Inglaterra. Por exemplo, o Colégio Royal de Médicos somou 683 membros em 1847, contra apenas 179 no início do século XIX (Peterson, 1978).

Os médicos combatiam, majoritariamente, a medicina 'marginal'. Desejavam modificações de suas funções médicas na sociedade inglesa, especialmente o reconhecimento do papel do médico (Cook, 2001).A população praticava muito mais 
o auto-cuidado doméstico do que a busca por médicos. Fórmulas caseiras e curadores populares eram de fácil acesso, e suas terapias possuíam mais credibilidade do que os cuidados médicos até o final do século XVIII (Porter, 1997).

Neste período, o conhecimento médico era baseado na teoria dos miasmas, assim designada por William Farr em 1854. Aqui neste ponto há uma semelhança de situações com o Brasil, conforme prévios apontamentos. Porém, desde a Idade Média tal teoria era praticada, embora ainda não denominada de 'miasma' (Worboys, 2000; Eyler, 1979). A peste negra, por exemplo, que acometeu a Itália na metade do século XIV, foi baseada na teoria dos miasmas (Rosen, 1993). Segundo Halliday (2001), Edwin Chadwick, por volta de 1846, considerou o odor como o causador das enfermidades. Muito embora a teoria dos miasmas tenha influenciado consideravelmente na medicina preventiva em séculos posteriores, médicos acabaram por exercer pouca influência de cura com estas concepções.

John Snow, no entanto, um médico desconhecido ainda na metade do século XIX, refutou a teoria dos miasmas: considerou que a água contaminada, ao invés do ar, era a causadora das doenças, especialmente do cólera (Halliday, 2001). Em Londres, esta epidemia ficou bastante conhecida porque matou parte da população nos bairros de Golden Square e Soho. Até então desconhecidas as causas das mortes, veio John Snow tentando explicar os motivos da doença, o que causou certo furor entre o meio científico da época sobre as teorias contagionistas do desconhecido médico (Johnson, 2006).

Valendo-se destes embates sobre a teoria miasmática, e desconsiderando quaisquer ações positivas que médicos exerceram, somadas aos próprios desconhecimentos microbianos inerentes ao período, alguns autores como Fraser (1950) argumentaram sobre a profissão médica: diziam que os médicos do século XIX prejudicaram a saúde da população inglesa, considerando-os 'ignorantes', com pouco conhecimento em assuntos médicos; defendeu também que estes profissionais fizeram do início do século XIX um hospital 'sujo e infectado', o que contribuía para caracterizar este período como uma época perigosa, de 'doenças severas' (p. 29-30). Mas foi com o Ato Médico de 1858 que os médicos ganharam um espaço privilegiado na sociedade inglesa, com o reconhecimento governamental de que eram profissionais importantes e que influenciariam a medicina do país em momentos posteriores (Parry \& Parry, 1976; Cope, 1959). Esta participação dos médicos com influência na sociedade inglesa do século XIX trouxe resultados significativos para aqueles que 
usavam as artes de cura populares, e foi neste espaço 'vazio' que também adentramos nossa investigação para compreender os usos e desusos dessa terapia popular.

Outros profissionais também vivenciaram situações semelhantes. Os cirurgiões foram outros indivíduos importantes na saúde pública do século XIX. Hoje, um cirurgião é reconhecido como um profissional médico especialista em cirurgia, mas naquela época, o cirurgião era um simples 'retalhador' de partes do corpo, exercendo suas sangrias, suas operações cirúrgicas de modo rudimentar, sem assepsia e sem segurança para o doente. Suas funções na saúde eram, muitas vezes, misturadas aos ofícios dos barbeiros, que sangravam corpos, faziam a barba, cuidavam de doenças (Edler, 2006). De fato, até a metade do século XVIII, os cirurgiões trabalharam juntamente com os barbeiros na Companhia de Barbeiros-Cirurgiões. A Companhia dos Cirurgiões foi formada em 1745, e durou até 1800. O Colégio Royal de Cirurgiões de Londres foi mantido de 1800 a 1843, e o da Inglaterra, criado em 1843 (Cope, 1959).

Basicamente, a carreira de um cirurgião iniciava-se por um aprendizado como um cirurgião-assistente. Considerava-se um avanço para sua profissão quando o cirurgião conseguia um assento como membro no Colégio Royal de Cirurgiões ou outro colégio de importância similar. Conforme Wheeler (1996) aponta, os avanços na profissão de cirurgião dependiam das qualificações do profissional, de ser preferencialmente membro do prestigioso Colégio Royal de Médicos, além de serem patrocinados por alguma entidade médica. Wheeler mostrou que o jovem prático já com todas as qualificações deveria procurar o patrocínio de médicos londrinos daquele momento e tentar se estabelecer como um prático especialista ou, mais comumente, retornar às províncias como um clínico geral. (p. 9-10).

Algumas vezes junto com médicos, trabalharam para auxiliar na saúde pública inglesa. Especialmente nos dispensários (Wheeler, 1996) e em tempos de guerra, criando formas de se combater, por exemplo, doenças como o escorbuto, muito comum pela alimentação seca e salgada carente em vitamina C (Bown, 2005; Behrendt, 2001).

Wheeler (1996) argumenta ainda que os cirurgiões enfatizaram, com a participação na criação destas instituições, a ineficiência da lei dos pobres: tentavam buscar outras alternativas para as classes baixas da sociedade inglesa. Segundo ainda este autor, Henry Lilley Smith foi um cirurgião que criou a Enfermaria dos Olhos e Ouvidos em Warwickshire em 1832, e posteriormente, estimulou a criação de outros 
dispensários na Inglaterra. Segundo Brown (1980), cirurgiões da cidade de Bristol trabalharam também na área farmacêutica. O ganho de prestígio dos cirurgiões ao longo do século XIX também influenciou nas mudanças das curas populares, e foi neste sentido que tentamos caminhar. Entender o papel do cirurgião na sociedade inglesa do século XIX nos traria uma compreensão do que aconteceu na terapia popular.

Estes cirurgiões, por sua vez, confrontaram-se com os apotecários, onde estes últimos atuavam não somente na manipulação de fórmulas, mas também davam ‘conselhos médicos', especialmente nos séculos XVII e XVIII (Holloway, 1991). Estes apotecários trabalharam, à semelhança dos cirurgiões, por melhorias no sistema de saúde inglês, atuando como os 'médicos' dos pobres e dos ricos, quando o perigo ou o sofrimento não eram muito complicados, especialmente em Londres (Holloway, 1966).

Os apotecários e os cirurgiões, junto com os médicos, faziam parte das três corporações médicas dos séculos XVIII e XIX, o Colégio Royal de Médicos, a Companhia de Cirurgiões e a Sociedade Worshipful de Apotecários (Waddington, 1984). Das indefinições nos séculos XVII e XVIII, o século XIX transformou a atuação profissional dos apotecários na saúde, migrando para outra esfera de trabalho: foram protegidos legalmente pelo estabelecimento do Ato dos Apotecários de 1815 (Holloway, 1991).

Os apotecários foram submetidos a inspeções de seus estabelecimentos de trabalho, suas drogas e seus métodos de composição de medicamentos. A maioria dos apotecários trabalhava sem possuir, necessariamente, uma 'loja' de medicamentos, diferentemente dos químicos e droguistas, cujas lojas foram a sua principal característica $^{13}$ (Holloway, 1991).

Estes químicos e droguistas, com suas habilidades 'médicas', também contribuíram para mudar o cenário da saúde pública. Segundo Holloway (1991), tornaram-se rapidamente os 'homens médicos': trabalharam para auxiliar as necessidades de saúde tanto da população rural como da urbana (p. 36-37). Não atuaram em cargos importantes da reforma sanitária como aconteceu com os médicos

\footnotetext{
13 Podemos considerar, neste ponto da análise, que os "nossos" químicos e droguistas foram os boticários que se destacaram até o início do século XX, pois à semelhança dos químicos e droguistas ingleses, também possuíam suas "lojas": elas nada mais eram do que as conhecidas boticas. De acordo com Edler (2006): "Essa imagem das velhas boticas perduraria, com algumas modificações, até as primeiras décadas do século XX, quando a industrialização crescente dos produtos farmacêuticos, a pressa dos fregueses e a venda do remédio já pronto inviabilizaram sua existência.” (p. 71).
} 
e os cirurgiões, mas exerceram seus papéis na saúde trabalhando como 'conselheiros médicos' nas zonas inglesas de maior carência. Eram mestres na arte de fazer fórmulas. Herbalistas e médicos botanistas, médicos e químicos e droguistas também foram outros profissionais de saúde responsáveis pelo cuidado ao doente (Brown, 1980).

De acordo com Holloway (1991), "The rise of the chemist and druggist is inseparable from the introduction of new forms of retailing" (p. 32). O aumento no consumo de produtos, por volta de 1780, contribui, assim, para elevar o comércio de produtos, beneficiando químicos e droguistas. $\mathrm{O}$ autor apontou que Londres foi uma das cidades mais importantes que contribuiu para o desenvolvimento de suas carreiras, e químicos e droguistas atuaram, principalmente, entre 1794 e 1858. Neste período, ressalta que “...the medical reform movement changed the meaning of selfmedication." (p. 61).

Segundo Marland (1987), foram considerados profissionais para-médicos durante o século XIX, auxiliando a população em questões diversas de saúde, principalmente em decorrência de um movimento incentivando o auto-cuidado: o objetivo deste movimento era o de permitir à população o livre-arbítrio na escolha de seus tratamentos. Personalidades importantes na área de saúde contribuíam para o crescimento de químicos e droguistas em suas profissões: Thomas Dunn, um profissional de saúde pertencente às elites, foi um exemplo de homem que elevou o prestígio dos mesmos, auxiliando-os com suas habilidades técnicas e financeiras. Possuía um estabelecimento farmacêutico com “...storerooms, a laboratory and workshop, a counting house, and residential accommodation for assistants, apprentices, and domestic servants." (Holloway, 1991, p. 47). Químicos e droguistas, entretanto, foram considerados terapeutas populares porque não possuíam 'credenciais médicas', mas interferiram muito no cuidado popular com suas habilidades de saúde pessoais. Este conhecimento 'não-oficial' gerou muitos conflitos com outros profissionais de saúde (Holloway, 1991).

Finalmente, da função dos químicos e droguistas, os farmacêuticos herdaram suas características. Eram os profissionais também responsáveis pela manipulação, venda e dispensação de medicamentos. Na Inglaterra, essa origem da profissão farmacêutica esteve ligada não somente aos químicos e droguistas, mas também aos cirurgiões e apotecários. Em um estudo que relatou a origem da farmácia na região nordeste inglesa, o autor descreveu um certo John Walker, o qual iniciou sua carreira 
como aprendiz de um cirurgião e de um apotecário; mais tarde, trabalhou como um droguista vendedor; em 1819, começou a dispensar medicamentos das prescrições dos médicos (Burnby, 1995).

Segundo Holloway (1991), o Ato Farmacêutico de 1852 aponta o início do processo legislativo que levou à presente divisão entre as profissões médica e farmacêutica. Antes deste Ato, havia uma remota integração entre químicos e droguistas, apotecários, médicos e cirurgiões. No entanto, o Ato surgiu para especificar cada ocupação da saúde: alguns eram responsáveis pelo diagnóstico; outros, somente pela manipulação de fórmulas. Tal manipulação e comércio de medicamentos foi incentivada pela revolução industrial, que proporcionou o crescimento da população e o desenvolvimento da indústria química. Acontecia a emergência de novos medicamentos, particularmente em 1840 (Morson, 1991).

Assim, estudamos as disputas entre os farmacêuticos e as outras classes profissionais da saúde para mostrar como o resultado desses embates, na forma de legislação e legitimação diante da população, alteraram a prática da terapia popular. Não há na literatura quem tenha mostrado as transformações das artes de cura a partir de uma análise da trajetória profissional de cada um deles.

De toda essa trajetória das profissões de saúde, os séculos anteriores ao XIX mostraram, segundo Inkster (1977), que todos estes profissionais na sociedade exerceram o papel de homens 'médicos' de província: não possuíam reconhecidas suas habilidades técnicas. Atingiram uma posição 'nobre' na sociedade ao longo destas lutas, com características políticas e morais envolvidas (Inkster, 1977). Holloway (1991) aponta que o Colégio dos Médicos, somados ao dos cirurgiões, eram considerados mais importantes que o Colégio dos Farmacêuticos Químicos no século XIX.

Apesar de todo esse processo de transformações nas profissões de saúde na Inglaterra, Hilary Marland (1987) considerou a impossibilidade de se excluir a medicina alternativa até a metade do século XIX, a despeito do desenvolvimento dos medicamentos industrializados. Destaca ainda que o século XIX vivenciou não somente a sobrevivência dos práticos populares tradicionais - “...folk healers, wisewomen, midwives, bone-setters, and itinerant quacks ${ }^{14}$." - mas também o surgimento

\footnotetext{
${ }^{14}$ Os quacks são aqueles indivíduos que praticam o quackery. Na definição do dicionário on-line Cambridge Advanced Learner's Dictionary, quackery significa a prática de métodos médicos que não funcionam e objetiva apenas o ganho de dinheiro. Disponível em:
} 
de grupos para-médicos como os homeopatas, os hidropatas, os botânicos e os químicos e droguistas (p. 415, 416):

The labels refer to a heterogeneous collection of individuals and groups, using varying methods of diagnosis and treatment, drawing on folk traditions, ancient remedies or the "new sciences" of, for instance, hydropathy, homeopathy, mesmerism or medical botany, or, in some cases, on showmanship, trickery or commercial enterprise. (p. 415).

Por outro lado, um dos motivos que alegaram Crellin (1994) e Fraser (1950) para tal continuidade das práticas populares foi a ausência de cuidados médicos. Neste misto de rupturas e de reconhecimentos das profissões de saúde foi que tentamos compreender os embates profissionais de saúde à luz das práticas populares de cura durante o século XIX na Inglaterra.

http://dictionary.cambridge.org/define.asp?key=64657\&dict=CALD\&topic=faking-and-pretending. Acesso em 26-01-2010. Segundo Porter (1997), o século XVIII foi a "era de ouro" da prática de quackery. Acrescenta ainda que as origens deste termo são obscuras, e que podem ser originárias do holandês quacksalver, significado para um doutor quicksilver, quando o mercúrio foi largamente usado para tratar a sífilis (p. 284). Segundo o dicionário citado, quicksilver é um termo antigo que significa um metal pesado de prata que se torna líquido em temperatura ambiente. Este metal líquido seria o mercúrio. Consultar: Enlightenment. In: The greatest benefit to mankind. A medical history of humanity from Antiquity to the present. Londres: Fontana Press, Harper Collins Publishers, p. 245-303. 


\section{Metodologia}

Nesta seção, discutimos sobre o método de análise que foi utilizado no estudo, ressaltando os motivos que nos levaram a tal escolha, bem como as vantagens e as dificuldades da metodologia empregada. Justificamos também a escolha pela investigação na Inglaterra e no estado de São Paulo, bem como o recorte temporal de 1815-1858 e 1892-1930, respectivamente.

Em primeiro lugar, optamos pelo olhar comparativo em nossa análise, almejando compreender como a regulamentação das profissões de saúde alterou a terapia popular em São Paulo e na Inglaterra. Inicialmente, pensamos em estabelecer uma relação entre São Paulo e Inglaterra, analisando as influências da Inglaterra no estado de São Paulo. Ainda que houvesse relações fortes entre a Inglaterra e o Brasil como um todo, estas eram, basicamente, de ordem econômica, e não voltadas para a área de saúde ${ }^{15}$.

Nestas condições, tentamos trabalhar com as semelhanças e as diferenças que existiram nestas duas sociedades, buscando uma origem comum (Bloch, 1995). A comparação baseou-se no que Barros (2007) argumentou sobre a utilização do método comparativo em história: fez uma leitura de Marc Bloch sobre a comparação das sociedades inglesa e francesa após a Primeira Guerra Mundial - destacou a importância de não tornar o enfoque histórico somente com uma única narrativa, centrada num único objeto de análise. Mostrou que o nacionalismo foi um dos motes que ocasionaram a guerra, e que a visão histórica monocêntrica circunscrevia demasiado a narrativa. A opção pela abertura desta narrativa aconteceria com o estudo de mais de um local, ressaltando suas semelhanças e suas diferenças.

Embora o estudo comparativo de Bloch tenha sido de sociedades sincrônicas, isto é, que se encontram em um mesmo período no tempo, Barros (2007) ressalta que

\footnotetext{
${ }^{15}$ Houve uma relação importante na área da saúde entre Bahia e Grã-Bretanha: a criação da Escola Tropicalista Baiana, fundada no final do século XIX, cujo principal médico de influência no Brasil foi um britânico chamado John Ligerwood Paterson. Diagnosticou a febre amarela na população baiana em 1849, contestando a teoria dos miasmas; além disso, implantou o curativo de Lister na região, que posteriormente tornou-se um método de assepsia na medicina mundial. Trabalhou durante algum tempo na Universidade de Edimburgo, mas passou grande parte de sua vida em Salvador. Consultar: Figuerôa, S. F. de M. Ciência e medicina fora da Corte: a Escola Tropicalista Baiana. História, Ciências, SaúdeManguinhos, vol. 9, n. 3, p. 715-716, 2002; Benchimol, Jaime Larry. A instituição da microbiologia e a história da saúde pública no Brasil. Ciência \& Saúde Coletiva, vol. 5, n. 2, p. 265-292, 2000; Peard, J. G. Race, Place and Medicine: The Idea of the Tropics in Nineteenth-Century Brazilian Medicine. Durham, S.C.: London Duke University Press, 315 p., 1999.
} 
"No caso da comparação de sociedades distanciadas no espaço e no tempo tinha-se uma situação singular: a ausência de interinfluências entre as duas sociedades examinadas. Neste caso, o trabalho consistiria basicamente na busca de analogias situação para a qual poderemos exemplificar com a possibilidade de estabelecer uma comparação entre o que se poderia chamar de "feudalismo europeu" e o que poderia ser denominado "feudalismo japonês", duas realidades afastadas no espaço, em uma época em que não poderiam transmitir influências uma à outra.” (p. 11). Em adição, o estudo de dois ou mais locais permite uma compreensão melhor do que a análise de um caso único, “...englobando fatores heterogêneos”. (Goldman citado por Cardoso \& Brignoli, 2002, p. 416).

Bloch (1995) afirma ainda que o estudo de sociedades separadas no tempo e no espaço possibilitam “...preencher, por meio de hipóteses baseadas na analogia, certas lacunas de documentação; abertura de novas direcções para a investigação, sugeridas pela comparação; sobretudo, explicação de muitas sobrevivências, até aí incompreensíveis." (p. 122). Esta incompreensão das sobrevivências foi rapidamente levantada também por Foucault (2006), onde o autor destacou a importância de se estudar os mesmos grupos de pessoas nas sociedades em regiões diferentes, em momentos diferentes: por exemplo, a questão dos grupos de dissidência religiosa nos séculos XVII e XVIII na Inglaterra, que lutavam contra a religião de estado; estes mesmos grupos reapareceram no século XIX não mais para combater a intervenção estatal na religião, e sim para lutar contra a medicalização da sociedade, para brigar contra a autoridade da medicina oficial frente às decisões em matéria de saúde e de doença. Ressaltou a importâcia de se analisar estas diferenças não somente na Inglaterra, como também em outras regiões (p. 96), que foi uma de nossas tentativas ao eleger um estudo comparativo entre Inglaterra e São Paulo, reforçando a importância desta análise paralela entre os dois locais.

Por outro lado, Bloch (1995) ressalta que tal busca por analogias é perigosa, se não se descobrir as relações causais da origem comum e também o percurso e os resultados dessa evolução (p. 117-138). As semelhanças podem acontecer ao acaso, não havendo uma justificativa para tal acontecimento: "O que atestam, não é a existência, entre os dois sistemas considerados, de estreitas relações de filiação, ou de interdependência, ou ainda a sua semelhança genérica é, mais simplesmente, a tendência do espírito humano para reagir, em circunstâncias análoga mais ou menos da mesma maneira." (p. 114). 
Tentamos ser cautelosos quanto aos anacronismos, aos exageros e às confusões que ocorrem ao comparar espaços, pessoas ou coisas. Segundo Cardoso \& Brignoli (2002), os anacronismos podem acontecer especialmente quando há confusão entre “...analogias superficiais com similitudes profundas, sobretudo em se tratando de sociedades estruturalmente bem diversas, ou muito afastadas no tempo." (p. 413). É bastante comum confundir comparação com justaposição, e que isso ocorre pelo acúmulo de descrições de casos individuais seguidos (Barraclough citado por Cardoso \& Brignoli, 2002).

Consideramos, ademais, o que Bloch (1995) chama de 'interpolação das curvas': as descontinuidades, as interrupções no processo histórico que auxiliam "a encontrar, por analogia, entre os diversos elementos das séries evolutivas que a insuficiência dos nossos conhecimentos fazia parecer descontínuas, os elos em falta." (p. 116). Por exemplo, a falta de documentos que poderiam explicar determinado fenômeno e que não existem; mas a presença documental em outra civilização distante pode sugerir alguma explicação para tal observação. Bloch ilustra tal interpolação recorrendo aos métodos curativos na Idade Média: “Os poderes curativos reconhecidos durante a Idade Média e até muito mais tarde a certos soberanos europeus tornaram-se muito menos inexplicáveis para nós depois que a etnografia permitiu reconstituir a atmosfera psicológica em que se desenvolveram outras crenças análogas." (p. 117).

Dentro deste olhar comparativo, portanto, buscamos identificar como médicos e farmacêuticos começaram a construir o seu estabelecimento profissional nas respectivas sociedades em torno das necessidades terapêuticas de saúde do indivíduo, em nosso caso, do uso da terapia popular como forma de cura. Partimos, assim, da legislação que envolvia questões importantes que influenciaram na mudança da busca por estas formas alternativas de cura. Fatores como o saneamento, os medicamentos, as epidemias, a industrialização, as instituições filantrópicas, as mudanças no ensino em medicina e em farmácia, o desenvolvimento das ciências farmacêutica e médica, todos funcionaram como complementos para os entendimentos sobre as questões envolvidas nas profissões médica e farmacêutica. Deste ponto de partida, tentamos analisar como médicos e farmacêuticos começaram a ganhar espaço na saúde pública inglesa e paulista. Quando falamos em estabelecimento profissional, pensamos em estruturas de poder que vão se formando nas sociedades, e que se 'fixam' nelas por um tempo ou permanecem até que haja alguma ruptura no processo histórico. 
Segundo Machado (2006), tais estruturas de poder podem se formar não necessariamente por intervenção do Estado na tomada de decisões: o poder pode se originar da periferia para o centro, onde este seria o Estado e, a periferia, outras forças dentro da sociedade que originariam tais poderes. Atenta ainda que é a partir deste poder periférico que “...se deveria partir para explicar a constituição dos saberes nas sociedades capitalistas." (p. XIV). Assim, as classes médica e farmacêutica, juntamente com o Estado, seriam o poder central ao qual Foucault se refere, pois estas classes, em suas necessidades de se estabelecerem como uma corporação profissional, voltaram-se para as necessidades de saúde da população para atingirem seus objetivos. As forças periféricas da sociedade que consideramos neste estudo seriam a população que praticava as artes de cura. Como a grande maioria da documentação prima pelo discurso de autoridades governamentais e de saúde, é difícil encontrar, por exemplo, relatos de um doente contando sobre qual terapeuta popular procurou, ou qual medicamento tomou para curar sua dor. Neste sentido, consideramos que os discursos das disputas dos profissionais médicos e farmacêuticos, junto às autoridades governamentais, representavam o que a população fazia, o que ela desejava e o que ela não desejava.

Sob o referencial teórico de Michel Foucault (1994, 2006), tentamos construir um discurso voltado para a construção deste poder periférico, sob o olhar de médicos e de farmacêuticos, que acabou por influenciar em decisões governamentais sobre saúde, tanto na Inglaterra como no estado de São Paulo. Tal poder teria se formado pelas necessidades públicas de mudança em saúde observadas pelas classes profissionais do período de análise. Dessas necessidades, juntamente com os seus ‘saberes científicos', caminharam para a consolidação de seus próprios interesses: o que chamamos de 'estabelecimento' das profissões de saúde - em nosso caso, de médicos e farmacêuticos. Essas necessidades públicas mudaram a maneira destes profissionais enxergarem o que as populações paulista e inglesa tanto praticaram em seus respectivos períodos de análise: a terapia popular.

Foucault (2006) argumenta que a institucionalização do olhar médico deu-se com a organização do espaço hospitalar no século XVIII, e que “...o surgimento progressivo da grande medicina do século XIX não pode ser dissociado da organização, na mesma época, de uma política da saúde e de uma consideração das doenças como problema político e econômico, que se coloca às coletividades e que elas devem tentar resolver ao nível de suas decisões de conjunto.” (p. 194). 
Argumenta ainda que o século XVIII mostrou o poder central desempenhando diversas funções em conjunto com outras esferas da sociedade: exemplifica com os grupos religiosos, as associações de caridade, as sociedades científicas.

Peguemos, por exemplo, o mesmo caso analisado por este autor sobre as resistências contra a medicina que tentava controlar os pobres na Inglaterra a partir de 1832, já mencionado anteriormente. Argumenta que grupos resistentes surgiram no século XIX tentando ir contra a medicina oficial, medicalizada, clamando pelo direito de cuidar de seu próprio corpo, de poder escolher a melhor forma “...de viver, de estar doente, de se curar e morrer como quiserem.” (p. 96). A despeito das decisões finais serem tomadas pelo poder central, as forças periféricas, neste exemplo dado representadas pelos grupos de resistência, agiam no sentido de serem 'ouvidas' pelas autoridades governamentais a fim de que suas reclamações fossem levadas em consideração. Assim, tais ações infuenciariam sobremaneira nas mudanças na área de saúde pública a partir do século XIX.

Ressalta ainda que a transformação da doença em objeto político relaciona-se ao desenvolvimento urbano, comercial e industrial. É quase como se dissesse que as doenças, de certa forma, passaram a ser 'criadas' como tal (isto é, como fatos sociais que merecem atenção e dispêndio de esforços pela sociedade) pelas instâncias sociais que dela dependiam para se estabelecer como grupo na sociedade: "Antes da civilização, os povos só tinham as doenças mais simples e mais necessárias. Camponeses e gente do povo ainda permanecem próximos do quadro nosológico fundamental; a simplicidade de suas vidas deixa-o transparecer em sua ordem racional: não têm os males de nervos variáveis, complexos, misturados, mas sólidas apoplexias ou puras crises de mania. À medida que se ascende na ordem das condições e que a rede social se fecha em torno dos indivíduos, "a saúde parece diminuir gradativamente"; as doenças se diversificam e se combinam; seu número já é grande "na ordem superior do burguês;,...ele é o maior possível na alta sociedade"" (Foucault, 1994, p. 17).

Partindo desse referencial teórico, justificamos, em segundo lugar, a escolha da investigação pelo estado de São Paulo e pela Inglaterra. A eleição pelo estado de São Paulo foi baseada principalmente em suas circunstâncias econômicas, sociais e políticas às quais estava inserido o estado no período da Primeira República, que trouxeram mudanças importantes para a área da saúde pública: foi uma região do Brasil que ganhava um novo impulso com a proclamação da República, com o 
crescimento do cultivo do café no Oeste Paulista, por exemplo, que trouxe novas conformações para a saúde do trabalhador. Ao mesmo tempo, a nova legislação sanitária iniciada em São Paulo trouxe modificações profundas no escopo da saúde, que muito influenciaram na saúde pública de todo o país. Profissionais de saúde estavam se adequando não somente às novas necessidades da população, mas também a seus próprios interesses. Além disso, passaram por transformações com o advento da revolução industrial, uma vez que o desenvolvimento da indústria farmacêutica no estado de São Paulo dava seus primeiros passos, influenciando nas práticas de terapia populares do período. Produção de medicamentos sintéticos e mezinhas andavam lado a lado. Rigor e ordem eram os novos temas incluídos na saúde pública paulista, com uma fiscalização mais estreita nas práticas de cura e nos terapeutas envolvidos.

Nestas condições, o estudo em São Paulo iniciou-se em 1892, data do estabelecimento da nova legislação sanitária no estado; e finalizou-se em 1930, ano que marca o final do primeiro período republicano brasileiro. Entre estas fronteiras, saneamento, industrialização, profissionais de saúde e artes de cura populares foram passando por mudanças.

Quanto à Inglaterra, sua seleção justifica-se pelo fato da reforma em suas bases sanitárias também ter ocorrido, com preocupações similares às que existiam quando da criação da nova legislação sanitária aqui, com atenções voltadas para a melhoria das condições de saúde da população. Apesar da reforma inglesa ter acontecido em um período diferente, anterior a de São Paulo, a Inglaterra encontravase na esteira da urbanização, como aqui, e sentia os reflexos das conseqüências que ocasionaram a Revolução Industrial iniciada neste país. Se lá a urbanização e a revolução industrial criavam interesses para reforma sanitária, aqui a imigração e a produção com trabalho assalariado também demandavam cuidados diferentes.

Por outro lado, as diferenças sabidas entre as duas regiões podem ajudar nas interpolações que aludimos anteriormente. Por ser parte do 'velho mundo', com instituições mais antigas e consolidadas, o número de informações disponíveis ao pesquisador nesse país é maior que aqui.

De fato, o país apresenta um dos maiores centros documentais em história da medicina. A exemplo da Wellcome Library, que permite o acesso de pesquisadores de todos os países a diversos tipos de documentos de variadas regiões do mundo. Em adição, a British Library, outra instituição que conta com um grande acervo na área de 
história, em seus vários ramos de atuação, não somente da Inglaterra, como de toda a Grã-Bretanha.

Somado a estes fatores, a Revolução Industrial transformou os meios urbano e rural de muitas regiões: a industrialização ocasionou o aumento de maquinário na agricultura, de processos industriais em algumas áreas específicas, do comércio de produtos e de serviços, somada ao aumento populacional, às mudanças no comportamento das populações, às modificações em questões de saúde, saneamento, transporte, habitação. No Brasil, por exemplo, a partir da Primeira Guerra Mundial houve um crescimento de vários setores industriais. Mesmo com a entrada não muito expressiva das indústrias químicas e farmacêuticas, já havia um início industrial aqui. Por exemplo, o período entre 1919 e 1932, os produtos farmacêuticos e químicos estavam dentre os principais ramos de produção, conforme cita Prado Júnior (2008). Segundo Bermudez (1995), por outro lado, a indústria farmacêutica ganharia força somente após a II Guerra Mundial.

Esse desenvolvimento industrial não ocasionou modificações somente aqui. A própria Inglaterra, quando iniciou sua reforma sanitária, focou as mudanças do saneamento na saúde do operário fabril, decorrente dos reflexos de se garantir uma significativa produção industrial: o objetivo era o de fornecer boas condições de saúde para que o trabalhador produzisse mais. Gioda \& Aquino Neto (2003) apontam que “A saúde ocupacional ${ }^{16}$ nasceu com a Revolução Industrial e é em grande parte fruto dos movimentos trabalhistas ingleses" (p. 1390). Com base nisso, almejamos compreender se a situação inglesa neste período de reforma sanitária se aproximaria da nova legislação sanitária paulista do final do século XIX. Em São Paulo, o crescimento urbano e industrial também teve como conseqüência a necessidade de se dar melhores condições de saúde para os trabalhadores. A diferença entre os dois locais encontrava-se no fato de que, em São Paulo, não havia somente os trabalhadores fabris, como também havia os trabalhadores da lavoura: muitos eram os imigrantes que aqui aportavam para se dirigirem às lavouras do café. Ao passo que na Inglaterra, o enfoque foi dado para o trabalhador da fábrica.

A preocupação com o trabalhador fabril no estado de São Paulo era consequência da expansão cafeeira, cujo processo, que ia desde a produção até o

\footnotetext{
${ }^{16}$ Os autores destacam que a saúde ocupacional visa o bem-estar dos trabalhadores em aspectos físicos e mentais, objetivando a proteção contra eventuais riscos aos quais tais trabalhadores possam estar sujeitos. Ainda segundo estes autores, atentam que se começou a utilizar o termo "saúde ocupacional" somente em 1957.
} 
consumo, baseava-se na exportação deste produto pelo Porto de Santos (Prado Júnior, 2008; Hochman, 2006; Mota, 2005). De 1892 para 1893, foram 130 milhões de dólares a mais pela exportação de café neste porto (Dean s/d citado por Mota, 2005). Assim, era importante a industrialização do produto, considerando o processo de torração, moagem e outras etapas (Prado Júnior, 2008) Neste sentido, o trabalhador fabril era peça importante no estado, e sanear as cidades, portanto, era fundamental para que esse operário dispusesse de condições sanitárias salubres, e a legislação era grande parte voltada para as área urbanas (Blount, 1971 citado por Hochman, 2006).

Além disso, cabe aqui uma nota sobre a importância das melhorias no saneamento urbano paulista para que o trabalhador rural pudesse trabalhar em condições mais salubres. Segundo Hochman (2006), era preciso 'preparar' as cidades para a entrada dos trabalhadores, principalmente Santos e a cidade de São Paulo, “...duas paradas obrigatórias para qualquer imigrante...” (p. 213). Essa preparação envolvia a prevenção de doenças e a melhora do espaço sanitário urbano para que o trabalhador não levasse epidemias para o campo, ou se tornasse doente e improdutivo na lavoura do café (p. 213-214). Costa (1985) atenta que o trabalho de Emílio Ribas de 1897-1918 era o de “...sanear as cidades de São Paulo, ligadas à expansão cafeeira." (p. 42). Emílio Ribas desejava preservar a saúde dos imigrantes italianos que chegavam em São Paulo, especialmente da febre amarela. Assim, este médico tratou de cuidar de cidades como Santos, Campinas, Sorocaba, Jaú, Ribeirão Preto em questões como a drenagem de águas paradas (para desaparecerem os criadouros de insetos) e a remoção do lixo (para diminuir a quantidade de mosquitos). Mota (2005) argumenta ainda que embora as cidades tenham sido um ambiente tão insalubre quanto o meio rural, atraíam grande quantidade de indivíduos dispostos a viver no meio urbano em busca de melhores condições de vida. Neste sentido, era preciso melhorar também as condições rurais para que as doenças trazidas pelos trabalhadores do campo não infestassem tanto as cidades (p. 37-38).

Assim, de um passado bastante diferente, de processos de desenvolvimento das duas regiões relativamente distintos, dos próprios caminhos diferentes percorridos pelos profissionais de saúde, almejamos analisar a possibilidade de encontrar conseqüências aproximadas entre São Paulo e Inglaterra nas questões referentes à terapia popular, já que as mudanças legislativas representaram um processo similar nos dois locais, ainda que sob condições diferentes. Além disso, os profissionais de ambas as localidades passavam pelo processo de normatizar suas atividades, que 
levaram à regulamentação de suas profissões, e consideramos isto fundamental para compreender como tais regulamentações levariam a alterações nas artes de cura populares.

Destacar, portanto, as necessidades de saúde das duas sociedades considerando seus métodos de cura populares utilizados, a partir da investigação da trajetória das profissões de médico e de farmacêutico, foi nosso objeto de análise.

Assim, consideramos o período inicial de investigação na Inglaterra em 1815, data que corresponde ao primeiro ato das profissões de saúde, o Ato dos Apotecários. Estes profissionais foram os primeiros a passarem por uma regulamentação estabelecida para legitimar a profissão do apotecário, fixando seu papel como agentes de saúde na sociedade do início do século XIX. O período final da análise foi determinado no ano de 1858, com o passar do mais importante ato para os profissionais de saúde, o Ato Médico de 1858 inglês. Foi a partir desta determinação que os médicos ganhariam, de fato, um tratamento diferenciado frente às instâncias governamentais. Consideramos, ainda, não somente a cidade de Londres, capital do país, mas toda a Inglaterra, dado que a revolução industrial foi iniciada em cidades mais ao norte do país, como Manchester, Rochdale e Lancashire. Londres, adicionalmente, não era o principal centro econômico, político e social do país àquela época (Bynum, 2006; Burns, 1966).

Em terceiro lugar, utilizamos, para construir esse olhar histórico-comparativo, fontes primárias e secundárias que dialogaram entre si para o entendimento da perspectiva histórica que adotamos. Como fontes primárias, direcionou-se a busca da documentação concentrados, inicialmente, em documentos que indicassem diretamente o exercício das práticas de cura populares pela população. Mas as dificuldades foram grandes, já que praticamente não há discursos documentados com a 'voz' do lado popular, especialmente porque nosso período de estudo é bem distante do momento presente. Partimos, então, para a busca de indícios que tivessem relação indireta com as artes populares, mas que mostrassem algum tipo de controle, de regulamentação em cima da terapia popular. Nestas condições, focamos a busca de documentos nas legislações e nos discursos dos profissionais de saúde dos períodos estudados.

Em São Paulo, consultamos a coleção de leis e decretos do estado de São Paulo entre 1892 e 1930, cujos volumes foram encontrados em locais diferentes que complementaram o período: uma parte na biblioteca da Faculdade de Saúde Pública 
da Universidade de São Paulo, outra na biblioteca da Secretaria de Estado da Saúde, outra parte ainda no Arquivo Público do Estado de São Paulo; consultamos também alguns anuários demógrafo-estatísticos do estado de São Paulo, encontrados nas bibliotecas da Faculdade de Filosofia, Letras e Ciências Humanas, de Saúde Pública e de Direito, todas da Universidade de São Paulo; jornais de circulação popular e correspondências com diversas autoridades, estas últimas inseridas na Inspetoria de Fiscalização da Medicina e da Farmácia, todos do acervo do Arquivo Público do Estado de São Paulo; revistas científicas médicas e farmacêuticas do período estudado, encontradas nas bibliotecas da Faculdade de Medicina, de Saúde Pública e do Conjunto das Químicas, todas também da Universidade de São Paulo. Quanto às revistas médicas elegidas, tomamos como base para a seleção os periódicos médicos mais citados pela historiografia consultada, que consideramos relevantes para nossa análise. Quanto às revistas farmacêuticas, consultamos a base de dados da biblioteca do Conjunto das Químicas e partimos para a busca dos periódicos que envolviam farmacêuticos e químicos na sinopse de cada uma das revistas.

$\mathrm{Na}$ Inglaterra, consultamos os atos gerais públicos da Grã-Bretanha e a coleção de relatórios dos comitês em saúde da Inglaterra de 1815 a 1858, todos encontrados nos arquivos da British Library; livros escritos por médicos, cirurgiões, químicos e droguistas, apotecários e farmacêuticos deste mesmo período, bem como de alguns períodos anteriores e posteriores, que encontramos nas bases de dados da British Library e da Wellcome Library; revistas de circulação popular de 1815-1858 da coleção da British Library; coleção filatélica dos selos ${ }^{17}$ de medicamentos referentes a este período do acervo da British Library; iconografias do acervo da Wellcome Library; materiais de museus que contavam com um acervo sobre os profissionais de saúde que estudamos. O direcionamento para a seleção dos documentos na Inglaterra baseou-se na documentação que já tínhamos em mãos de São Paulo, para que facilitasse a posterior comparação entre os locais. Porém, não encontramos na Inglaterra, exatamente os mesmos tipos de documentos disponíveis aqui, por isso as diferenças de fontes, com as quais tentamos trabalhar de maneira que a comparação se fizesse o mais coerente possível.

\footnotetext{
${ }^{17}$ Ver figura de alguns selos de medicamentos do século XIX na seção ‘Anexos’: pg. 158, Anexo I.
} 
Como fontes secundárias, a historiografia que consideramos relevantes para complementar a análise da pesquisa, que foi conseguida por meio de livros, teses e artigos científicos.

Por último, justifica-se o presente estudo pelo fato da historiografia atentar, até o momento, para pesquisas com um olhar na história das práticas populares em períodos anteriores ao republicano em diversas regiões do Brasil, e não considerando o papel de profissionais médicos ou farmacêuticos; outro enfoque não menos importante é o estudo das instituições médicas e dos profissionais médicos em São Paulo, mas que não contemplam o papel dos profissionais farmacêuticos. De fato, foram encontrados muito poucos estudos sobre estes profissionais com enfoque histórico. Na Inglaterra, grande parte dos estudos concentrou-se nas análises históricas de profissionais de saúde com recorte temporal anterior ou posterior ao período selecionado, não considerando a medicina popular como problemática de pesquisa. Além disso, o enfoque nas curas populares foi bastante abrangido, mas não envolvendo profissionais de saúde como médicos e farmacêuticos. Finalmente, destacamos o ineditismo de nossa pesquisa, já que (no melhor do nosso conhecimento) não há estudos comparativos na saúde entre o estado de São Paulo e a Inglaterra sob uma perspectiva histórica. 


\section{Um olhar comparativo entre São Paulo e Inglaterra}

\subsection{Condições de saúde durante o período de industrialização}

\subsubsection{Na Inglaterra}

No período anterior ao século XVIII, havia o predomínio do auxílio médico proveniente de entidades filantrópicas ou religiosas na Europa (Foucault, 2006). Com o processo de industrialização, a saúde começou a ganhar contornos com foco na saúde do trabalhador, onde o cuidado passou a ser especialmente contextualizado em termos de desenvolvimento da produção industrial (Thomas, 1997). Autoridades governamentais, profissionais de saúde e o meio popular responderam aos avanços industriais, e a seus reflexos na área da saúde. Por exemplo, os conhecidos manuais populares de higiene foram uma das mostras de que o operário fabril passava a ser importante na saúde pública. Um deles descreveu alguns métodos que melhorariam a saúde dos trabalhadores, enfatizando que

\footnotetext{
Amongst the latter is to be placed Mr. Abraham's plan for the protection of steel-grinders from the particles that fill the atmosphere of their work-rooms, by suspending a system of magnets around each grind-stone; it having been discovered that the most injurious matter, the dust of the grind-stone itself, still remains diffused in the air, as it is not susceptible of magnetic attraction. The great remedial measure for the evils we are considering resolves itself into thorough ventilation, and numerous facts might be brought forward to prove its efficacy. (Davis, 1836, p. 78-79, grifos nossos).
}

A preocupação não se restringiu somente à saúde dos trabalhadores, como também envolveu a família destes indivíduos. Mulheres e crianças eram também empregados destas fábricas. Conforme Hawksley (1868) apontou, crianças estavam expostas a péssimas condições de moradia nas hospedarias neste período: falta de saneamento e deficiências na saúde, somadas à ausência de educação escolar. Defendia o desenvolvimento de um sistema educacional com o intuito de criar melhores condições para estas crianças (Frazer, 1950).

O início do século XIX foi caracterizado por algumas determinações legislativas para melhorar a saúde de operários, de seus familiares e de outras pessoas com baixo poder aquisitivo. Por exemplo, um ato parlamentar em 1831 foi criado para proteger a saúde dos trabalhadores infantis nas fábricas (Collection of Statutes, 1831, p. 329). Um ano depois, estabeleceu-se o Ato da Reforma Sanitária de 1832, cuja 
determinação baseou-se nas condições ruins ainda do século XVIII, como as 'febres das prisões' e outras doenças, tratadas principalmente nos trabalhos de John Howard. O Ato da Reforma de 1832 foi o movimento inicial que alterou muitos aspectos da vida social não somente inglesa, como de toda a Grã-Bretanha em questões como a vida nas prisões, o cuidado à criança, o bem-estar da sociedade e a saúde pública (Cooper, 1989, p. 190).

No ano seguinte, o Ato das Fábricas de 1833, introduzido pelo Lorde Ashley, também visou a proteção às crianças contra os abusos no interior das fábricas, em adição à proteção aos trabalhadores adultos (Frazer, 1950). Segundo MacNalty (1946), o Conselho Geral de Saúde foi criado para trabalhar nestas questões. Apontou ainda que um membro da reforma sanitária inglesa, Thomas Smith, argumentou que a febre era o fator que trazia a pobreza para o país, pois atingia tanto adultos como crianças, e que ela era passível de prevenção (p. 97). Neil Arnott enfatizou também que era preciso prevenir estas febres e outras doenças, tendo como ponto de partida o desenvolvimento da medicina preventiva no controle desses problemas de saúde. Discutindo as condições de saúde precárias, um cirurgião publicou um tratado em 1831, relatando os problemas de:

250 English industries, including the chief ones, and he dwelt on the details of each according to their significance to health. His facts were incontrovertible, and in making them common knowledge he made industrial hygiene a matter of State responsibility. (MacNalty, 1946, p.107, grifos nossos).

Nestas condições, as autoridades governamentais continuavam desempenhando suas tarefas com o intuito de melhorar a situação fabril. Segundo Palmegiano (1998), uma das mais importantes reformas no século XIX foi a Emenda da Lei dos Pobres de 1834, criada pela Comissão da Lei dos Pobres em 1832. A lei de 1834 possuía o objetivo de conceder maior proteção à saúde dos trabalhadores fabris que eram acometidos por uma série de doenças ocupacionais. Somado a isso, tais operários eram habituados a tomar medicamentos por conta própria para aliviar seus sintomas de doença. Isso foi se exacerbando à medida que o desenvolvimento urbano e comercial permitiu a aquisição de produtos industriais pela população.

Apesar de Smith (1979) argumentar que o movimento sanitário do século XIX tenha sido uma tentativa de vencer estas barreiras de saúde, considerando a pobreza e 
a ineficiência dos serviços de saúde, havia discordâncias quanto à efetividade dessa reforma. Com efeito, o Dr. A. P. Stewart, um dos mais importantes membros da Associação para a Promoção da Ciência Social, considerou que as leis determinadas na reforma sanitária, as quais possuíam o objetivo de melhorar a saúde pública por meio dos aperfeiçoamentos no saneamento, não atingiram seu objeto inicial (Notes on Sanitary Reform, 1870). Uma nota escrita por outro membro da Associação (1870) reforçou o argumento de Stewart, atentando que,

\begin{abstract}
Misled and dazzled by our gigantic improvements, are we not neglecting the condition of those who form a vital part of the life of the nation? Is not our civilization crushing down those who have least power to help themselves? Does not the rapid growth of our commercial system, our achievements in the arts, and the marvellous increase in wealth, blind us to many of the defects which lie underneath, and are undermining the morality and strengh of the people? (p. 50).
\end{abstract}

De acordo com Gorsky \& Sheard (2006), a reforma em 1834 não ocasionou melhoras permanentes e os gastos governamentais em saúde trouxeram apenas resultados temporários (p. 95). A Emenda da Lei dos Pobres não gerou nenhum sistema permanente de assistência médica, e isto se deu em parte devido à dependência das associações voluntárias (Frazer, 1950, p. 28). Usando de um argumento ainda mais crítico, apontou-se que as reformas pelas melhorias sanitárias e de saúde não trouxeram benefícios na saúde do século XIX, e muito menos de quase todo o século XX:

Indeed it has recently been argued that, with the exception of smallpox inoculation, introduced in the eighteenth century, medical innovations did little to increase the expectation of life until at least the nineteenth century, and made no substantial contribution, sanitary reform apart, until the second quarter of the twentieth. (T. McKeown \& R. G. Brown, 1955; T. McKeown \& R. G. Record, 1962 citado por Thomas, p. 658).

A despeito destas discordâncias, as primeiras décadas do século XIX foram focadas em questões sanitárias nas áreas urbanas. Objetivava-se modificar a saúde inglesa considerando fatores de natureza política, econômica e social (Bynum, 2006). 
As epidemias deste período também contribuíram para o movimento da reforma. O ano de 1840 foi o que apresentou as piores condições de higiene e saneamento: conforme Rosen (1993) aponta, “Modern public health took its origin in England, because it was the first modern industrial country" (p. 170). Segundo Horner (1995), a indefinição do papel do estado neste período, e os conflitos das mudanças sanitárias espalharam a prática da medicina popular.

Thomas (1997), em contrapartida, argumentou que o surgimento de esquemas de segurança para os empregados das fábricas e a proliferação das instituições filantrópicas trabalhistas causaram uma diminuição das crenças na medicina popular, à medida que a industrialização se desenvolvia, bem como as preocupações em saúde inerentes ao desenvolvimento da produção industrial (p. 654). Atribuiu ainda o declínio das práticas populares de cura ao desenvolvimento da ciência e da tecnologia, as quais contribuíram por tornar o exercício da terapia popular como uma prática supérflua e inútil. Quanto mais o homem controlava o meio ambiente em que se encontrava, por meio desse desenvolvimento tecnológico e de suas descobertas científicas, menos usava os medicamentos "mágicos” (p. 648).

\subsubsection{No Brasil ${ }^{18}$}

O desenvolvimento das primeiras indústrias no país, da ciência e da tecnologia foram marcas importantes após a proclamação da república (Silva, 2003; Ribeiro, 2001; Rainho, 1996). Segundo Prado Júnior (1986), apesar da pequena parcela de indústrias aqui na Primeira República, houve um estímulo ao estabelecimento industrial por conta da disponibilidade de matérias-primas, mão-de-obra e baixos preços, principalmente pela economia voltada para a exportação de gêneros tropicais.

Em São Paulo e no Rio de Janeiro, os interesses industriais foram não somente governamentais, mas também privados das classes altas das sociedades paulista e carioca. Transformações econômicas e políticas, atreladas aos novos costumes sociais foram algumas das características que marcaram o final do século XIX brasileiro (Rainho, 1996; Telarolli Júnior, 1996; Costa, 1985).

Neste contexto, outros contornos para a saúde pública também modificaram os rumos do país. Uma questão importante era a melhoria do saneamento urbano, com

\footnotetext{
${ }^{18}$ Consideramos aqui somente os estados de São Paulo e Rio de Janeiro: este, por ser a capital federal no período em questão, e aquele, por ter sido uma região importante nas questões da reforma sanitária. Conforma aponta Hochman (2006): São Paulo desenvolveu “...uma política sanitária autônoma porém interdependente em relação aos resultados das ações dos demais estados e do governo federal.” (p. 16).
} 
foco na saúde do trabalhador, à semelhança da Inglaterra. A diferença residiu no fato das melhorias na saúde serem voltadas também para o trabalhador agrícola, e não somente fabril, como foi na Inglaterra. São Paulo possuía o café despontando como novo produto agrícola. O período da Primeira República foi marcado pela crescente produção e comercialização deste produto, somado ao aparecimento de maquinaria específica para a agricultura (Telarolli Júnior, 1996), o que contribuiu para fortalecer a classe rural e o comércio.

Com a abolição da escravidão, o progresso da cafeicultura estimulou a gradual substituição da mão-de-obra escrava pela mão-de-obra do imigrante. Entretanto, as autoridades estrangeiras reclamavam das condições sanitárias ruins às quais estes emigrados estavam expostos, especialmente a leva de italianos a partir da década de 1890, que totalizaram 58,5\% rumo a São Paulo (Camargo citado por Telarolli Junior, 1996). Segundo Telarolli Junior (1996), havia poucos cuidados médicos acessíveis no período da imigração. Os trabalhadores possuíam muito receio das doenças rurais, que caminhavam em paralelo às epidemias do período. O autor aponta que "Em São Paulo, a ação pública limitou-se às medidas necessárias ao controle das epidemias, através dos instrumentos que a tecnologia disponível, baseada na bacteriologia, punha à disposição da administração estadual, basicamente ações de polícia médica e campanha sanitária. Sob o ponto de vista das prioridades do nascente serviço sanitário estadual, fica claro que estas obedeciam à lógica e às necessidades do complexo cafeeiro, que não poderia conviver por muito tempo com uma situação em que epidemias, especialmente as de febre amarela, afetavam suas atividades em quase todas as etapas do processo produtivo.” (p. 67).

Mesmo com estas iniciais atenções governamentais na saúde, as condições financeiras dos trabalhadores eram precárias, e dependiam, portanto, dos trabalhos populares de curandeiros, barbeiros, curiosos e parteiras. Bertucci (1997) relata que o jornal popular A Plebe destacou esta busca por terapeutas do povo, durante a epidemia de gripe espanhola em 1918:

Giuseppina Possani, de 37 annos mais ou menos residente à Rua dos Italianos, soffrendo de uma enfermidade que lhe disseram ser incuravel, depois de exgottar todos os recursos, até recorrendo à exploração dos curandeiros, tentou suicidarse, atirando-se hontem às aguas do Tieté - na Ponte Grande. A pobre mulher foi salva por pessoas que a viram atirar-se ao rio. Quando a pobre gente do trabalho 
terá meios de tratar-se devéras das enfermidades que na sua maioria são adquiridas no proprio trabalho? (p. 80).

O desenvolvimento do espaço urbano levou ao aumento da população urbana, estimulado principalmente pelo comércio do café (Prado Júnior, 2008). Este comércio foi favorecido com a expansão da malha ferroviária no estado de São Paulo a partir do decênio 1880-1890 (Mota, 2005; Telarolli Junior, 1996). Ao mesmo tempo, Telarolli Junior (1996) nota que "A rapidez nos transportes facilitou a disseminação das epidemias na década de 1890 pela zona cafeicultora, levando doentes e vetores a locais ainda não contaminados. $\mathrm{O}$ avanço seqüencial das epidemias - café, ferrovias e febre amarela -, seguindo o trajeto das ferrovias, indicava para as autoridades sanitárias a íntima relação entre o transporte ferroviário e a ocorrência das moléstias." (p. 41). Desta forma, era preciso uma reforma na saúde na tentativa de controlar tais casos de doenças.

Além disso, o desenvolvimento da maquinaria para a produção do café também foi reflexo da transformação econômica à qual o país estava imerso (Telarolli Junior, 1996). Mas não foram somente as inovações tecnológicas relacionadas ao cultivo deste produto: embora a grande maioria dos inventos fosse relacionada à área agrícola (70\%), diversas invenções industriais em ramos como alimentação, vestuário, mobiliário, saúde e outros na virada do século XIX para o XX também caracterizaram este período. O desenvolvimento da medicina ocasionou um crescimento técnico e tecnológico das invenções médicas de $10 \%$ do total de inovações, especialmente nas áreas de higiene e saneamento (Rainho, 1996). Segundo esta autora, cujas invenções relatadas em seu estudo estão no acervo do Arquivo Nacional do Rio de Janeiro, "São inventos relacionados, como a produção de algodão esterilizado, a ambulância desmontável, a atadura esterilizada, as técnicas de conservação de cadáveres, os diversos estojos para médicos e dentistas, o esterilizador de material cirúrgico, uma construção móvel para hospital, inaladores de anestesia, aparelho para uniformização de temperatura em incubadora artificial, seringa para injeção sem dor, dispositivo para conservação de medicamentos à base de suco de crustáceo, entre outros.” (p. 323).

No que diz respeito à formulação de novos medicamentos, as inovações também sofreram influência do desenvolvimento tecnológico do período. Visavam curar, dentre muitos outros males de saúde, enxaqueca, febre, reumatismo, parasitas, hemorragia, cólera, febre amarela. A autora aponta, em sua discussão, que “...grande 
parte dos medicamentos era apresentada como invenção, e que o memorial descritivo que acompanhava os frascos e amostras dos remédios em geral se distanciava do discurso científico que embasava, por exemplo, as teses apresentadas às faculdades de medicina." (p. 323). Em face deste argumento, fica implícito o fato destas fórmulas possuírem um caráter 'caseiro', de natureza artesanal, com pouco rigor na produção dos mesmos.

Com efeito, Rainho (1996) exemplifica a criação de um preparado medicinal no início do século XX:

José Fernandes Cal apresentou, em 1904, um "preparado destinado a curar a febre amarela" que beirava a ingenuidade. O dito produto era, segundo seu inventor, um "medicamento composto de substâncias inofensivas, não contendo tóxicos" à base de limão, aguardente, conhaque superior (s/c), açúcar em infusão. (p. 324).

Em paralelo a estas práticas caseiras, a autora destaca que neste período Oswaldo Cruz era diretor geral da Saúde Pública no Rio de Janeiro, dando os primeiros sinais de erradicação da febre amarela: eram algumas normas que emergiam para reforçar a importância do cientificismo da época. Assim, o discurso popular e científico caminhavam lado-a-lado. Diferentemente do que apontou Thomas (1997) sobre o declínio da busca pela medicina popular na Inglaterra em decorrência do desnvolvimento da medicina. 


\section{As práticas de cura populares}

\section{Os séculos XIX e XX: Inglaterra e São Paulo}

Considerando este desenvolvimento tecnológico e industrial, somados à necessidade de melhorias na saúde, novas preocupações apareciam na esfera governamental. Um dos objetivos a serem alcançados por autoridades governamentais e de saúde era o de controlar as práticas de cura populares. Parte da busca por elas inseria-se como um caminho alternativo para aqueles que não possuíam outras opções de cura, ou ainda, eram inerentes àqueles que desejavam simplesmente se utilizar do cuidado popular. Tanto em São Paulo como na Inglaterra, a terapia popular foi uma prática comum durante ambos os períodos considerados (Souza, 2005; Silva, 2003; Thomas, 1997; Porter, 1997; Telarolli Junior, 1996).

De fato, momentos passados mostraram-nos que medicamentos foram muito produzidos artesanalmente por um sem-número de indivíduos. Foram usados também por um sem-número de pessoas em busca de alívio para suas enfermidades. Em adição, eram alvo de enriquecimento para muitas pessoas que os produziam, e isto se exacerbou especialmente ao longo dos séculos XVIII e XIX, onde novos contornos foram sentidos em decorrência do crescimento urbano e comercial (Porter, 1997).

$\mathrm{Na}$ Inglaterra, a busca por medicamentos em estabelecimentos de comércio aumentou com o surgimento de armazéns e pequenas lojas de serviços. Após 1780, esta procura aumentou ainda mais, pois houve uma elevação no consumo de bens e serviços (Holloway, 1991). O acesso fácil na aquisição de medicamentos contribuía para que as pessoas fizessem suas próprias escolhas, especialmente com a presença dos químicos e droguistas ${ }^{19}$, que manipulavam fórmulas (Marland, 1987).

A falta de médicos também contribuiu para o exercício das artes de cura populares em diversas partes do mundo (Rosen, 1993). A ignorância ou a falta de confiança nas funções dos profissionais de saúde também colaboraram na busca pela terapia alternativa (Crellin, 1994; Fraser, 1950). Crellin (1994) apontou que a terapia, seja ela prescrita por médicos ou práticos alternativos, é preocupação antiga para a sociedade. Argumenta ainda que esta prática contempla várias questões referentes ao auto-cuidado, que vão desde o comércio de drogas às influências religiosas ${ }^{20}$, e tudo

\footnotetext{
${ }^{19} \mathrm{O}$ capítulo 6 discutiu o papel destes profissionais de saúde na Inglaterra do século XIX.

${ }^{20}$ Sobre estas práticas religiosas, magias e outros cultos, ver quadro pintado por artista que satiriza as artes de cura não baseadas na medicina 'científica' da época. Intitula-se A laudable partnership or Souls \& Bodies cured without loss of time. Foi publicado em 1795, por George Moutard Woodward. O homem à esquerda, de óculos, é um quack; o homem à direita, um indivíduo que se passava por orador.
} 
isso em conjunto permite-nos compreender a complexidade e as nuances do que é chamado de "...silent health-care system." (p. 9).

No Brasil, contribuíram para isso não somente médicos diplomados e falsos médicos, mas também um rol de terapeutas populares como barbeiros e curandeiros (Witter, 2005; Pimenta, 2004; Figueiredo, 1999). A população possuía crença maior no poder dos curandeiros do que no poder de cura de profissionais 'licenciados' (Pimenta, 1998), à semelhança da Inglaterra. Por lá, inventaram medicamentos universais para curar febres, rubéola, escarlatina, catapora e debilidade senil (Smith, 1979, p. 343). Foi uma prática muito criticada durante todo o século XIX inglês. J. A. Carlyle (1830), editor da revista Fraser ${ }^{21}$, questionou os motivos da persistência desta prática na Inglaterra: "Por que isso acontece? Por que a Inglaterra foi o local escolhido para o exercício do charlatanismo? Como pode o ignorante ter sido expulso dos outros países europeus e encontrar abrigo aqui?" (p. 451), e apontou que tal prática era muito mais intensa em Londres.

Segundo McLaren (1977), um dos motivos que levavam à busca pela terapia popular foi a pequena interferência governamental até 1830. Estes terapeutas populares possuíam consciência de suas práticas, mas muito fizeram também por questão de sobrevivência. William Heath, pintor que viveu de 1795 a 1840 desenhou um 'doutor' charlatão, e acrescentou, em sua obra, os seguintes dizeres:

\section{THE QUACK DOCTORS CONFESSION on his Death Bed}

If the common Soft or Tub Soap made into a moderate strong lather, or half an ounce Liquor Potassoe in twelve ounces of Distill'd water - which is the late Dr Fordyces Prophylactic, or in the absence of these'th best Yellow Soap, were to be used as preventives of the Veneral Infection - there could be no longer any excuse nor even bread for one of my profession \& Callings. ${ }^{22}$

Estes terapeutas do povo defendiam o auto-cuidado na saúde inglesa. Pegavam exemplos de outros países que faziam as curas alternativas e tentavam incentivar a população inglesa dos benefícios dessas terapias. Um autor de um livro de botânica

Caricatura retirada do livro: The bruising Apothecary: images of Pharmacy and Medicine in caricature. Londres: The Pharmaceutical Press, p. 21-22, 1989. Ver pintura na seção 'Anexos', pg. 159, Anexo II.

${ }^{21}$ Conhecida como "Fraser's magazine", foi uma revista de circulação em toda a Inglaterra de 1830 a 1882, e abordava temas gerais de interesse público, como a saúde pública.

${ }^{22}$ Ver figura da pintura na seção ‘Anexos’: pg. 160, Anexo III. 
médica baseou suas observações nas práticas de um médico americano, Dr. Thompson, enfatizando que a Grã-Bretanha também deveria seguir tais ações:

\footnotetext{
...many have suggested the formation of friendly Botanical Societies amongst the working classes, and their extension to every part of the kingdom, that the people may mutually assist each other in the study of Medical Botany, and establish and propagate a general knowledge of these principles, so glorious in eradicating disease from society, and relieving it of much of that poverty and deplorable suffering which arise from wrong practice. (Stevens, 1849, p. xi).
}

Ao mesmo tempo, editores de revistas populares tentavam criar consciência na população acerca dos perigos no uso da medicina popular. Criticavam o uso dos medicamentos artesanais, enfatizando que os jornais contribuíam para veicular tais substâncias feitas por quaisquer “...Smiths, Joneses, and Thompsons.”. Alegou que funcionavam como pílulas purgativas apenas, e adicionou que o pior do charlatanismo naquele momento eram as práticas de homeopatia, hidropatia e magnetismo animal (Fraser's Magazine, 1848, p. 645-646).

Similarmente, os meios de comunicação impressos no estado de São Paulo veiculavam informações sobre novos medicamentos:

\footnotetext{
Laxativo - As pastilhas laxativas de V. Werneck são um medicamento que deve ser preferido a todos os outros, pois, regularizam o ventre e não exigem dieta de natureza alguma, nem mudança nos habitos ordinarios da vida. Modo de usar: uma pastilha ao almoço e outra ao jantar. Vendem-se em todas as pharmacias e drogarias. Deposito 72, rua dos Ourives, Rio de Janeiro. (Correio Paulistano, 7 dez. 1893, p. 3).
}

Interessante é a forma como a informação veio descrita: constava a sua utilidade terapêutica e o seu modo de usar, o que, implicitamente, excluía a necessidade de se consultar um médico.

Entretanto, à semelhança da Inglaterra, mudanças nas práticas de terapias alternativas também foram sentidas no estado. Embora o período inicial de análise na região paulista (1892) seja depois de quase 80 anos em relação ao período na Inglaterra (1815), algumas semelhanças existiram entre as duas localidades. As 
preocupações com a saúde pública de São Paulo e da Inglaterra partiram, por exemplo, de reformas na legislação de cada local, e um dos principais motivos para tais mudanças foram as doenças epidêmicas (Gladstone, 1997; Costa, 1985). Além disso, São Paulo teve um aumento no acesso aos novos medicamentos inventados, elevando o consumo dos mesmos, com novas possibilidades de cuidado à saúde para a população. Esta situação foi relatada em diversos periódicos de saúde do período republicano. Com efeito, embalagens atraentes de medicamentos em estabelecimentos de comércio como drogarias e farmácias foram consumidas desde o alvorecer da República:

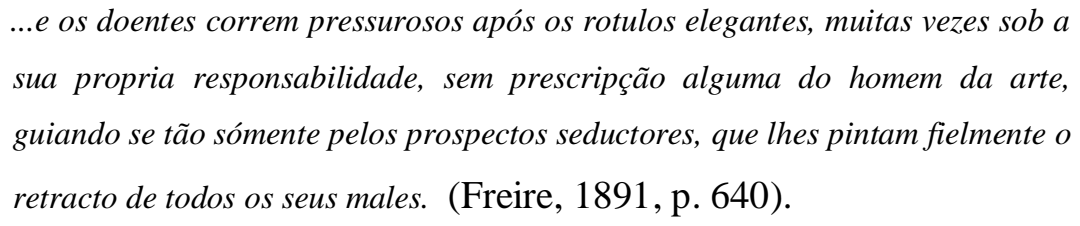

Também foi marcada por uma época com novas conformações sociais, políticas e econômicas (Ribeiro, 2001). Por conta disso, não somente de novas invenções industriais, como também de métodos próprios de 'doutores populares'; os próprios periódicos ironizavam as práticas de terapia destes populares. Consideravam que tais indivíduos compreendiam pouco acerca de doenças, e que somente o conhecimento médico 'diplomado' poderia lidar com a falta de saúde da população (Favero, 1928; Boutin, 1923; Soares, 1908). Uma seção especial da revista São Paulo Medico (jul. 1928) denominada "Supplemento literario e humoristico" destacou estas práticas:

Tratamento "Proprio"

Um doutor "especialista"

Foi chamado um certo dia

A casa duma modista

Que tinha uma nevralgia.

Doia o lado direito

Desde o pé até o pescoço;

Com a dôr não tinha mais geito

Doia tudo até o osso!

O doutor então começa

Um tratamento "especial", 
Dizendo: - Verá que cessa

Num instante esse seu mal!

Fez uma injeção prodigio
Com hervas (processo seu)

Para mostrar o prestigio

Que a medicina lhe deu!

E perguntou no outro dia

Si a dôr tinha passado.

- "Sim, doutor, a nevralgia

Já passou... para o outro lado..."(Effe, p. 405).

Nestas condições, diversos homens que atuavam como terapeutas populares acabaram por receber punição da própria Inspetoria de Fiscalização da Medicina e da Farmácia do Serviço Sanitário. Foi solicitada a abertura de inquérito policial para apurar a não habilitação do exercício da arte de curar de Manoel Ferraz Pacheco, alegando que o mesmo não possuía registro de título na Diretoria do Serviço Sanitário de Jaú (Correspondência com diversas autoridades, 1929, p. 47).

O controle das práticas populares estava direcionado não somente em termos de consumo de medicamentos industrializados, como também nos homemade remedies e nos 'charlatães domésticos' ${ }^{23}$ muito buscados na Inglaterra do século XIX. No Brasil, estes charlatães foram mais evidentes ainda no período imperial, onde o combate ao charlatanismo existia, especialmente devido ao desenvolvimento da medicina, que pretendia substituir as práticas populares pelo seu 'saber' científico. Segundo Machado e colaboradores (1978), "O império do saber aparece, assim, indissociável do império político" (p. 205): o desenvolvimento da medicina científica estava, neste contexto, atrelado às decisões tomadas pelas autoridades políticas do país.

Ao mesmo tempo, eram estimulados o exercício de populares e o uso de remédios e técnicas por eles produzidos. Machado e colaboradores (1978) referem-se especialmente à prática de homeopatia muito dissipada a partir de 1840 no Brasil, e destacaram a liberdade de exercê-la na província de São Paulo. Fazem menção a um homem, que se diz médico, chamado Gaspar Laroche, da cidade de Campinas, cujas

\footnotetext{
${ }^{23}$ No Brasil, o barbeiro atuou especialmente até o final do século XIX. Consultar: Santos Filho, Lycurgo de Castro. O barbeiro - Medicina popular - Curandeirismo - Folclore médico. In: História geral da medicina brasileira. São Paulo: Hucitec: Editora da Universidade de São Paulo, 1991.
} 
práticas foram, de início, protegidas pelo governo imperial. Coexistiam, assim, o charlatanismo e a medicina científica.

Além disso, o uso de manuais de medicina incentivou estas práticas de cura durante todo o período republicano no Brasil. Nas palavras de Santos Filho (1991): "O ano de 1842 assinalou a publicação, no Rio de Janeiro, do Dicionário de Medicina Popular, do médico Pedro Luís Napoleão Chernoviz. Desapareceu o de Bucham ${ }^{24}$, e houve tanta aceitação do novo manual, popularizou-se de tal forma o nome do autor que o "Dicionário" passou a ser conhecido em todo o país, e até o século XX, como "O Chernoviz."”, (p. 437).

Em São Paulo, o uso de medicamentos industrializados misturava-se à busca por métodos caseiros. Santos Filho (1991) acrescenta que o folclore médico foi outra terapia alternativa bastante buscada durante os séculos XIX e XX, que se opunha às descobertas da medicina científica:

...cultores, indivíduos brancos, pretos e mulatos, de ambos os sexos, foram e são os 'benzedores', 'rezadores', 'raizeiros', 'catimbauzeiros', 'santos', 'mães' e 'pais-desanto”” que exerciam “'rezas', benzeduras, visões, augúrios, palavras cabalísticas, passes espíritas, 'simpatias', 'despachos', amuletos, imagens, bentinhos, patuás, exvotos, fetiches, e toda uma vasta gama de componentes dos reinos animal, vegetal e mineral, desde as 'garrafadas', 'chás' e infusões aos objetos mais esdrúxulos e geralmente destituídos de qualquer ação medicinal (p. 442).

Com efeito, o Dr. Luiz Pierre Augusto Vergely, em seu "Tratado completo de medicina popular" (1922), publicou um livro sobre o uso da medicina popular com a finalidade de auxiliar os leigos em suas práticas 'médicas'. Estudou na Faculdade de Medicina de Paris, trabalhou no exército francês e no momento da publicação de sua obra era cirurgião e radiologista da Santa Casa de Jaú. O tom da publicação é ambíguo, pois é destinado a incentivar as práticas populares de terapia, mas não desconsidera a importância do saber científico, em evidência no período. Na seção "Introducção":

\footnotetext{
${ }^{24}$ William Bucham foi médico do Colégio de Edimburgo em fins do século XVIII. A edição de seu manual na qual tivemos acesso foi a de 1805, mas outras edições já haviam sido publicadas em momentos anteriores. Referência: Domestic Medicine: or, a Treatise on the Prevention and Cure of Diseases by Regimen and Simple Medicines. London: Printed for A. Strahan; T. Cadell and W. Davies, Strand; and J. Balfour, and W. Crefch, Edinburg, 1805.
} 
Este livro é destinado ao povo. Procurei escrevel-o de modo que seja comprehendido mesmo pelas pessoas da mais modesta instrucção. Apresso-me, porém, a affirmar, que não o fiz para incitamento daquelles que, podendo recorrer aos socorros medicos, delles prescindem deliberadamente.

Difficil arte é a medicina. Pretender que, depois da leitura de uma obra, ou depois de alguns annos de má pratica, sem guia, esteja alguem habilitado na arte de curar é, por isso mesmo, puro engano.

Si é verdade que os medicos, em geral, não possuem qualidades excepcionaes que os distingam dos outros homens, tambem é certo que os que se dedicam á difficilima arte, preparados por longos annos de trabalho, constantemente em contacto com os enfermos, estão mais habilitados a prestar soccorros efficazes, do que as pessoas que apenas acabam de obter uma informação nas paginas de um livro, sem a certeza de que essa informação se applica ao caso presente (p. 1).

Ainda afirma que esta publicação não influenciará no aumento das práticas de charlatães:

Mas, acima de tudo, o autor tem esperanças de que seu livro virá a prestar muitos serviços aos que se acham impossibilitados de recorrer aos medicos, pois nelle se contém todas as indicações para os casos urgentes. Todas as molestias poderão ser tratadas sómente com o auxilio deste livro, se as distancias ou outras difficuldades não permittirem aos doentes assistencia do profissional.

Este livro será indispensavel a todos os que pretendem curar, sem ter estudos medicos especiaes.

Não augmentará, por certo, o numero dos curandeiros e poderá tornar mais habeis e menos perigosos os que existem. Aconselho-os a lel-o e, mesmo, a estudal-o com attenção. Sómente depois deste estudo preparatorio é que poderão encontrar opportunamente as informações necessarias, pois ha no livro, expresso em termos simples, tudo o que é necessario á clinica corrente (p. 2).

Segundo Santos Filho (1991), diversos médicos foram adeptos destes manuais de diagnóstico e terapia populares, como forma de auxiliar a população que carecia de cuidados médicos. Este autor aponta que o Dr. Pereira Barreto, além de suas atividades no ramo da agricultura (foi o criador da variedade 'Bourbon' de café, florescente no Oeste Paulista), foi doutor de uma universidade européia, e publicava 
artigos em revistas de cunho popular, como o 'Almanaque Literário', publicação corrente no período imperial e parte do republicano. Nas palavras do autor:

Doutor pela Universidade de Bruxelas, Bélgica (1864). Revalidou o diploma na Faculdade do Rio de Janeiro em 1865. Clinicou em Jacareí e depois na capital da Província de São Paulo. Médico renomado, senador do "Congresso Constituinte Paulista", deputado federal, positivista, autor de "As três filosofias” (1874-76) e de diversos ensaios. O “Guia médico” publicou-se primeiramente no "Almanaque Literário" de José Maria Lisboa, São Paulo, 1879. (p. 441).

Nestas condições, o diagnóstico popular de doenças com seus respectivos tratamentos se complementavam. Entretanto, a Revista Pharmaceutica (1899) apontou alguns males no uso de medicamentos, especialmente aqueles criados por meio das descobertas químicas. Na seção 'Medicamentos Artificiaes' :

A hystoria de todos estes productos “medicamentos novos" obtidos por synthese
que data de 1860, é quasi impossivel de coodenal-a, e nem nos atrevemos a
incetal-a pois se o fisessemos ficariamos atordoados antes de chegar ao fim;
limitamos nos a algumas ligeiras consideraçóes sobre sua inutilidade e seu
perigo.
Muitos anos foram precisos para conhecer-se alguma cousa sobre as
propriedades da quinina, da strichina e outros medicamentos que a natureza
benevolamente pôs á nossa disposição; podemos agora admittir que tal ou tal
producto obtido hontem ou a semana passada possua virtudes milagrosas?!

(Vasconcellos \& Hollanda, 15 ago. 1899, p. 53).

Mesmo com o desenvolvimento inicial da produção industrial de medicamentos sintéticos, ainda recorria-se muito àqueles manuais médicos. A seção "Pharmacia de urgencia" do livro de Vergely (1922) ilustra essa prática:

Damos a seguir uma lista de medicamentos indispensaveis. Póde parecer longa, mas a sua acquisição não é dispendiosa e esses remedios, que se compõem só de substancias que não se alteram facilmente, podem ser conservados indefinidamente num pequeno armario ou num cofrezinho. Entretanto, para que se conservem melhor, devem ser preservadas da humidade, do calor e da luz ( $\mathrm{p}$. $524)$. 
Lista e uso dos medicamentos

Laudano Sydenham - 20 grammas - O laudano emprega-se ás gotas. Podem-se dar 10 gotas pela bocca, como calmante de colicas ou qualquer outra dôr abdominal. Essa dóse póde ser repetida até 3 vezes por dia se fôr necessario.

No caso de queda grave sobre o abdomen oude ferimento profundo do abdomen é bom dar immediatamente 50 gotas de uma vez.

O laudano póde ser tambem applicado em lavagem intestinal na dose de cinco a dez gotas, para acalmar as dôres intestinaes ou uterinas. Pode-se accrescentar a essa lavagem uma gramma de atipyrina.

Póde-se ainda applicar localmente sobre a pelle, uma dose de 30 gotas, sobre um linimento para esfregar sobre a pelle com uma colher de chá de laudano, outra de chloroformio e quatro colheres de sopa de azeite doce.

Não se deve empregar o laudano para as creanças pequenas (p. 524-525).

Embora o desenvolvimento da ciência médica estivesse trazendo outras condições para os cuidados populares, havia bastante resistência em trocar, ou mesmo utilizar, os conhecimentos advindos desse olhar científico que tentava se estabelecer. Tanto na Inglaterra como em São Paulo, a alopatia era deixada de lado em detrimento de práticas como a homeopatia, o hypnotismo e outras técnicas não reconhecidas oficialmente. $\mathrm{Na}$ Inglaterra, um falso médico defendeu a reforma inglesa médica baseada no estímulo de práticas como a homeopatia, à semelhança do período imperial brasileiro:

It is asserted by true medical reformers that allopathy is a system of crude dogmas, of ever-shifting theories, and of evervarying practice. Even the father of medicine recognized in part, the truth of the homoeopathic law.

I- That in a large proportion of the cases treated by allopathic physicians, the disease is cured by nature, and not by them.

II- That in a less, but still not a small proportion, the disease is cured by nature, in spite of them; - in other words, their interference opposing, instead of assisting the cure.

III- That consequently, in a considerable proportion of diseases, it would fare as well, or better, with patients in the actual condition of medical art, as more generally practised, if all remedies - at least, all active remedies - especially drugs, were abandoned. (Medical Reform, 1856, p. 3-5, grifos nossos).

Em São Paulo, a prática do hipnotismo também foi alvo de algumas reflexões no campo da medicina popular: o Dr. F. Fajardo (1896) publicou o "Tratado de 
Hypnotismo", argumentando que esta técnica milenar, que remonta à tradição judaica, sofria uma mudança com a medicina científica, e que esta influência traria novas regras para os experimentos de hipnose, com o auxílio de diversas áreas do saber, como “...á physiologia, á pathologia, á therapeutica, á criminologia e á medicina legal." (p. XII). Era adepto da união das medicinas popular e científica para o melhor desempenho da hipnose. Na realidade, cada indivíduo, seja médico popular ou não, fazia um discurso que mais se aproximava de seus interesses privados: isso passa a ser relevante pela ausência de evidências que comprovassem, em números, a eficácia desse hipnotismo, por exemplo. Ou ainda a eficácia de determinado medicamento industrializado.

Em paralelo, outra característica destas práticas foi o fato delas terem tido a participação de mulheres na cultura de cura popular, já que havia o predomínio da população do sexo masculino. Essas mulheres atuavam, geralmente, em suas famílias como as curadoras das doenças (Mott \& Alves, 2006). Possuíam, como uma das principais práticas no início do século XX, de conduzir partos. De acordo com Mott \& Alves (2006), era elevado o número de parteiras registradas no serviço sanitário entre 1892-1919, sobretudo de italianas: “...51\% eram nascidas na Itália e $43 \%$ tinham diploma no país de origem; $19 \%$ eram brasileiras e $42 \%$ dos diplomas, atribuídos por escolas nacionais..." (p. 24). Nestas condições, a legislação paulista criou formas de limitar o seu exercício:

Artigo 52. Ás parteiras fica prohibido:

O tratamento medico ou cirurgico das molestias de mulheres e creanças, os annuncios de consultas e as receitas, salvo nos casos especiaes, de parto.

(Toledo, 1896, p. 47).

Esta regulamentação acabou por legitimar a função de outros profissionais de saúde, os quais combatiam as práticas dessas mulheres, alegando sua falta de conhecimentos em técnicas médicas. Elas atuavam também dando conselhos médicos sobre medicamentos e doenças, o que fez determinados profissionais as considerarem como mulheres 'perigosas'. Conforme Zuquim e colaboradores (1898) destacam, “' $E$ assim que parteiras, alem do emblema ridiculo e inconveniente que têm as portas annunciarão especialidades, ate de abortos." (p. 22). 
O que não ficava explícito foi o fato destas mulheres terem auxiliado gestantes que não possuíam outros meios de dar à luz, ou simplesmente preferiam o trabalho das parteiras em detrimento do trabalho de um médico. Os embates profissionais deixavam claro que o 'medo' dessas mulheres não ocorria só por conta do mal que fariam à saúde das gestantes, mas principalmente por ameaçarem suas profissões. $\mathrm{O}$ Decreto n. 780, de 26 de abril de 1900, até dava determinadas condições para que parteiras exercessem suas práticas rotineiramente, enquanto não houvesse novas leis para o seu exercício. Às parteiras não diplomadas, era exigido um exame de habilitação de acordo com este decreto: o artigo $6^{\circ}$ determinava que elas deveriam saber sobre "Anatomia da bacia e do apparelho genital da mulher...", "Physiologia da prenhez ..." e "Pathologia, clinica e therapeutica obstetrica." (Queiroz, 1900, p. 110).

Porém, a Inspetoria de Fiscalização da Medicina e Farmácia do Serviço Sanitário estava atenta às práticas das parteiras. Abriu um inquérito policial para apurar a responsabilidade de Maria Cedrin - segundo a correspondência, exercia ilegalmente a obstetrícia, infringindo o artigo 232 do Decreto Federal n. 16.300, na capital de São Paulo (Correspondência com diversas autoridades, 1929, p. 41). Similarmente, a Inglaterra do século XIX também apresentou um grupo de mulheres com destacada importância nas práticas populares. Eram também responsáveis por preparar fórmulas caseiras e misteriosas:

Many of the traditional herbal healers were the wise women, living in villages, who commanded great respect - and not a little fear - because of their healing powers. The rise of allopathic medicine and its use of inorganic chemicals was accompanied by the systematic disparagement of women's powers to heal using natural herbs and other plants. During the $17^{\text {th }}$ century many women were ultimately condemned as witches, tried by mob, and burned at the stake or drowned, for practising natural herbal medicine. (Farrer-Halls, 2003, p. 10).

Porém, uma diferença importante residiu no fato destas mulheres serem originárias, principalmente, de instituições de caridade e de dispensários antes e depois do século XIX (Farrer-Halls, 2003; Massie, 1995; All the Year Round, 1866). O início do século XIX mostrou o envolvimento dessas mulheres no cuidado aos doentes mentais. A maioria delas trabalhou em conjunto com seus maridos em asilos; 
ou herdou estes locais em decorrência da morte de seus cônjuges. Na maior parte do tempo, estas mulheres atuaram como 'servas' de seus parceiros (Massie, 1995).

Atuaram também como parteiras, como aconteceu em São Paulo, mas de modo bem menos frequente. Timothy Watkins, um clínico geral da cidade de Towcester-Litchborough, em Northamptonshire, publicou em seu livro uma lista de nomes de mulheres que faziam partos em 1802: "Nancy Herring", "Mrs. Andrews", "Mrs. Watts" (Midwifery, 1790-1804).

A maior participação da mulher no cuidado à saúde aumentou após 1850 , principalmente por causa da Guerra da Criméia em 1854. Eram majoritariamente irmãs e enfermeiras que trabalharam como voluntárias, ou ainda, herdaram posições em instituições de enfermagem. Florence Nightingale foi umas das mais importantes personalidades na história do cuidado militar. Ficou conhecida como 'The Lady with the Lamp'. Possuía o hábito de andar entre os doentes com uma lâmpada, cuidando de suas injúrias da guerra (Summers, 1983). Além dela, Mary Seacole, chamada de 'Mother' Seacole, foi outra mulher de destaque nas guerras britânicas. 'Prescrevia' medicamentos, além de ter organizado o estoque alimentar e alguns outros cuidados básicos com a saúde dos militares - ratos infestavam os campos de guerra (Sally, 2005; Ziggi \& Dewjee, 1982). Ambas somavam um misto de caridade e ganância política: embates entre elas próprias e com outras mulheres para ver quem era a mais capaz de ser a 'líder' militar.

No estado de São Paulo, as enfermeiras começaram a se destacar na saúde logo após 1890 (Mott \& Alves, 2006). Segundo estas autoras, “...ao lado dos classificados das parteiras, começam a aparecer na imprensa anúncios de enfermeiras oferecendo serviços ou sendo requisitadas para trabalhar em domicílio; matérias escritas por ou sobre Dra. Maria Rennotte, primeira médica da cidade...” (p. 24). O cuidado aos doentes era reforçado não somente por estas enfermeiras que atuavam ainda de maneira tímida no cenário paulista, mas também por outras mulheres que exerciam as práticas populares da enfermagem. Conforme aponta o Dr. Getulio F. dos Santos em seu "Livro do Enfermeiro e da Enfermeira. Para uso dos que se destinam á profissão de enfermagem e das pessoas que cuidam de enfermos." (1916): explica para o profissional ou o leigo algumas das principais características que o cuidador do doente deveria ter ao exercer a enfermagem. Na seção "Prescripções medicas em geral': 
Prescripção medica é a indicação, geralmente escripta, dos medicamentos e dos conselhos concernentes á hygiene e regimen do doente, depois de examinado pelo medico.

Os medicamentos ou remedios são liquidos, solidos e gazosos. Os enfermeiros recebem-n'os já preparados, ordinariamente, e os devem empregar escrupulosamente como lhes foi recommendado. (p. 247).

O interessante é que este médico foi membro do Serviço Sanitário do Exército e da Cruz Vermelha Brasileira, mostrando um pouco a influência da Primeira Guerra Mundial na medicina em São Paulo. A grande maioria dos profissionais que partiam para a guerra era de médicos. É possível que mulheres voltadas para as práticas de enfermagem, juntamente com médicos, tenham atuado no período da guerra, como aconteceu na Inglaterra no período da Guerra da Criméia: mulheres, especialmente as já reconhecidas oficialmente como enfermeiras, mais médicos, foram paliativos importantes dentro do campo de batalha (Sally, 2005; Summers, 1983; Ziggi \& Dewjee, 1982). 


\section{Químicos e droguistas, apotecários e cirurgiões na Inglaterra ${ }^{25}$}

\subsection{Químicos e droguistas}

Homens e mulheres que atuaram como curadores de doenças não foram as únicas classes de terapeutas populares envolvidos no cuidado à saúde antes do século XIX. Havia um grupo 'diferenciado' de populares que também influenciaram na saúde pública inglesa, os químicos e droguistas ${ }^{26}$. Consideramos como um grupo diferenciado porque eles foram os indivíduos que mais influenciaram nas mudanças da reforma médica inglesa dentre aqueles homens e mulheres que exerciam os cuidados populares. Foram ganhando legitimidade ao longo do século XIX frente às esferas governamentais, aumentando os desejos de reforma nas profissões de saúde pelos outros profissionais da área. Ao mesmo tempo em que não possuíam ‘credenciais' para atuar nas práticas médicas, tinham um espaço dentro das decisões parlamentares, levantando pontos de discussão importantes relativos ao seu exercício dentro da sociedade inglesa, especialmente no século XIX. Isso teve um resultado importante para quem estava envolvido nos cuidados populares de cura antes do século XIX, que se prolongou durante este mesmo século.

Porém, antes de químicos e droguistas serem conhecidos pelos seus trabalhos em conjunto, atuaram separadamente, em dois grupos diferentes. Químicos eram considerados mais "aptos" do que os droguistas, que foram considerados menos capazes de fazer fórmulas pelo Parlamento até a metade do século XVIII. De fato, o Parlamento considerou que o químico era o indivíduo responsável por cuidar da arte da preparação de fórmulas, pois possuía experiência em manipular solventes para extrair componentes de tecidos vegetais e animais, além de ter habilidade na preparação de drogas. Segundo ainda as autoridades parlamentares, poderiam controlar fraudes e outras situações de abuso (An enquiry Into the Designs of the late Petition resented to Parliament by the Company of Apothecaries, 1748, p. 49).

A partir de 1794, começaram a ficar conhecidos na sociedade por seus trabalhos em conjunto, espalhando suas práticas de cura pela Inglaterra, e tal situação foi mais evidente até a metade do século XIX. Segundo Marland (1987), houve um aumento no número de pessoas envolvidas na área de farmácia até a metade do século

\footnotetext{
${ }^{25}$ A investigação de profissionais com função semelhante em São Paulo fica como agenda de pesquisa.

${ }^{26}$ Droguistas no estado de São Paulo também foram indivíduos bastante procurados no exercício das artes de formular remédios. Segundo Costa (1895), medicamentos eram muito vendidos em casas de ferragens por estes droguistas: “...que não podem vender drogas a pesos medicinaes e a retalho $e$ entretanto o fazem." (p. 48).
} 
XIX, com significado especial para os químicos e os droguistas, não somente porque cresciam em números, mas também porque se mostraram independentes dos apotecários; e após a determinação do Ato Farmacêutico de 1854, que detalhamos mais adiante, surgiram importantes implicações para a profissionalização e a identidade do profissional químico (p. 417).

Basicamente, as funções dos químicos e droguistas concentraram-se na produção e venda de fórmulas químicas, inicialmente, em estabelecimentos pequenos e simples. Ao longo do século XIX, estes estabelecimentos tornaram-se mais sofisticados, e o comércio de medicamentos, muito lucrativo para químicos e droguistas. Envolveram-se também no 'diagnóstico' de doenças e na indicação de medicamentos. Os doentes eram acostumados a buscar seus estabelecimentos à procura de um conselho médico, sendo uma das formas mais fáceis de se buscar auxílio na saúde. Segundo Marland (1987), a venda de drogas sem prescrição, de ingredientes para os medicamentos, das preparações patenteadas ${ }^{27}$, dos medicamentos familiares para dores peitorais e das curas especiais de todas as doenças, tornaram-se os alicerces do comércio de químicos e droguistas durante o século XIX (p. 422-423).

Para destacar a importância destes homens frente à esfera governamental, um Ato sancionado em 1815 destacou uma proteção no comércio de medicamentos conduzido por eles:

Provided always, and be it further enacted, That nothing in this Act contained shall extend, or be construed to extend, to prejudice, or in any way to affect the Trade or Business of a Chemist and Druggist, in the buying, preparing, compounding, dispensing, and vending Drugs, Medicines, and Medicinable Compounds, wholesale and retail; but all Persons using or exercising the said trade or Business, or who shall or may hereafter use or exercise the same, shall and may use, exercise, and carry on the same Trade or Business in such Manner, and as fully and amply to all Intents and Purposes, as the same Trade or Business was used, exercised, or carried on by Chemists and Druggists before the passing of this Act (Public General Acts, 1815, p. 1743, grifos nossos).

Tal comércio de medicamentos era facilitado, por exemplo, por um almanaque distribuído para a população, produzido pelos próprios químicos e droguistas, onde as

\footnotetext{
${ }^{27}$ No capítulo 7 tratamos sobre estes medicamentos.
} 
pessoas podiam escolher o medicamento por este almanaque, e a agência responsável por tal publicação se incumbia de fazer as remessas pelo correio. Esta agência fez um acordo com os correios, onde estes enviavam os medicamentos em embalagens leves e seguras, e facilitavam a transferência do pagamento feito pelo cliente para os correios. Os editores do almanaque enfatizaram, ainda, que as entregas alcançariam quaisquer regiões do Reino Unido (Hannay \& Dietrichsen Almanack, 1842, p. B6).

Assim, conseguiram o apoio de muitos consumidores adeptos de suas fórmulas. Essa facilidade no acesso a medicamentos era uma ferramenta que contribuía para o exercício das curas populares na sociedade inglesa do século XIX, pois não havia proibições legais nessas 'transações' medicamentosas. Com efeito, a eficácia das pílulas digestivas Dyson foi reforçada pelo testemunho de um consumidor, dentre muitos outros, no Hannay \& Dietrichsen Almanack (1842):

To Messrs. Dyson \& Co.

Gentlemen,

I feel it my duty to add my testimony to the beneficial results experienced from taking your Antibilious Digestive Pills. My family have used them some time: they fully substantiate the truth of your advertisement. I am persuaded it is a very valuable discovery, and deserves to be patronised. You have my permission to make my sentiments public.

I remain, Gentlemen,

Your most obedient servant,

CHARLES MUMFORD (p. B11, grifos nossos).

Quando estes medicamentos eram estampados com o selo governamental, era sinal de sua aprovação frente às autoridades políticas. Isso dava crédito para a função de fazer fórmulas dos químicos e droguistas. A publicação da eficácia de uma pomada 'divina' no Hannay \& Dietrichsen Almanack (1842), a qual servia para curar câncer, torcicolo e prevenir úlceras, mostrava que o medicamento vinha com o selo anexado em cada vidro de pomada. Foi veiculada desta forma:

THE TRUE POMADE DIVINE: “...It is useful in all sorts of Swelling and Bruises, occasioned by Falls or otherwise, and will prevent the many bad consequences of such accidents. For a Cancer before it is broke, and for sore Breasts, particularly in Lying-in. For a stiff neck, and for swelling occasioned by the Evil. For the Piles, and will prevent a Fistula. (...)”. "Price 2s. 9d. the Glass 
As there are numerous counterfeits of this valuable Pomade in circulation, it is requisite to observe that this, which is the only genuine preparation, prepared from the original receipe, has the words "Hannay and Dietrichsen, 63, Oxford Street”, engraved in and printes on the Government Stamp attached to each glass. (p. B38, grifos nossos).

Ao mesmo tempo foram considerados os 'charlatões dos medicamentos', principalmente por outras classes de indivíduos ligados à área da saúde, a despeito destes incentivos e facilidades para a sua atuação. Por exemplo, profissionais de saúde que atuavam nas instituições de caridade, as quais funcionavam como um paliativo para as pessoas de baixa renda, reclamavam da ação dos químicos e droguistas: a população acabava aderindo aos conhecimentos destes homens em detrimento destas casas de saúde. Estes outros profissionais alegavam que os químicos e droguistas possuíam incentivo às práticas de venda de medicamentos sem a necessidade de prescrição médica. Nessa reclamação, não dá para identificar se foi um cirurgião, um médico ou um apotecário quem criticou os químicos e droguistas:

... and to the scarcely less dangerous practice of the druggists; what is usually called counter practice, that is, the prescribing of half-educated persons, without any sufficient examination of the patient, often without any examination at all, which is frequently resorted to by the poorer classes, for the sake of avoiding the expenses of medical attendance, which they are ill able to afford. (An Essay on Dispensaries, 1838, p. 11, grifos nossos).

O interessante é que em algumas das publicações dos químicos e droguistas, eles próprios mostravam os tipos de medicamentos que manipulavam, a diferença dos seus medicamentos populares em relação àqueles que seguiam as regras de produção de um livro de referência. Diziam que seus medicamentos faziam parte mais de testes do que de aplicação prática propriamente dita: incluíam, na lista, os medicamentos secretos conhecidos como "Quack Medicines", preparações de várias drogas elaboradas por fórmulas pessoais; incluíam também os mais favoritos medicamentos de uso doméstico; e ainda alguns compostos, já não como medicamentos de testes, mais conhecidos somente por aqueles que faziam uso em cada circunstância específica de doença (The Druggists General Receipt Book, 1852, p. 157). 
Vejamos como exemplo, uma das várias composições medicinais desses terapeutas. O medicamento possuía a função de aliviar a congestão de pulmões inflamados:

Bateman's Pectoral Drops. 1. Compound spirit of aniseed 16 fluid ounces, opium 1 dr., camphor $1 d r$., oil offennel 20 drops, cochineal $2 d r$.

2. Proof spirit 4 gal., red sanders 2 oz.; digest 24 hours, filter, and add powdered opium 2 oz., camphor 2 oz., catechu 2 oz., oil of aniseed 4 fluid drachms; digest for 10 days. Philadelphia College of Pharmacy. The old wine gallon is here intended. (The Druggists General Receipt Book, 1852, p. 161).

Apesar de toda esta liberdade para veicular seus medicamentos, de dar conselhos médicos e de saber que eram individuos importantes na saúde inglesa do século XIX, a falta do 'diploma' causava desconforto para os químicos e droguistas. Esse incômodo era sentido pela pressão exercida pelos outros profissionais de saúde, que argumentavam que o cuidado à saúde deveria ser administrado por profissionais com conhecimentos aprofundados em medicina e farmácia, e isso se daria por meio de prover educação técnica para estes populares.

Em paralelo, a 'prescrição' de medicamentos começava a ser considerada uma forma de charlatanismo por um comitê de saúde inglês, apontando a prevenção das atividades de químicos e droguistas de vender quaisquer medicamentos oriundos de suas fórmulas secretas (Reports from Committees, 1852). Estes profissionais, além de trabalharem com seus medicamentos secretos, envolveram-se na adulteração de drogas, e a avaliação de um membro externo do Comitê de Adulteração de Medicamentos mostrou que os químicos e droguistas deveriam ser licenciados para, por exemplo, vender medicamentos (Reports from Committees, 1856). Uma discussão de A. H. Hassal, um médico londrino importante que atuava na comissão sanitária de análise não somente de drogas, como também de alimentos e de bebidas, mostrou a relevância dos tipos de adulteração, em geral associadas a ganhos financeiros pessoais. Acrescentou que a grande parte das adulterações provinha de drogas originárias do estrangeiro:

Are English drugs adulterated? -Nearly all drugs are subject to adulteration which it will pay to adulterate. The majority of drugs are foreign. There are 
very few drugs which are grown at home. Still there is no reason, in consequence of their being grown at home, why they should not be adulterated, provided there be sufficient temptation to do so. It is always a question, I am afraid, of mere profit. (Reports from Committees, 1855, p. 248, grifos nossos).

Ao lado de suas fórmulas caseiras e da adulteração de drogas, químicos e droguistas envolveram-se também com a impureza das drogas. $\mathrm{O}$ fornecedor de matérias-primas possuía o hábito de vendê-las a preços baixos para os químicos e droguistas, desrespeitando a pureza das substâncias constantes na farmacopéia inglesa (Reports from Committees, 1855). Os comitês que controlavam a qualidade das drogas atentavam para os perigos aos quais a população inglesa estava exposta. A sociedade recebeu 'conselhos' médicos de químicos e droguistas sobre os usos destes medicamentos adulterados e impuros:

\footnotetext{
Is it usual for a poor person to go into a chemist's shop and ask for 20 grains of calomel? - It is not unusual. I may state that in the localities which have been referred to as those in which the adulteration of drugs principally exists, medicines are rarely dispensed from prescriptions. In reference to the majority of the druggists from whom those specimens were got, they would not have a prescription once a week, or some of them not once a month, to make up. Their business consists in selling drugs to poor people, who doctor themselves. They get a little advice with the medicine from the druggist occasionally, that is to say, if they buy rhubarb they inquire how they are to use it, if they do not know; therefore it is for domestic use that those things are sold. That is almost the whole of the business of those little druggists in such localities as I refer to (Reports from Committees, 1855, p. 383, grifos nossos).
}

Nestas condições, aumentaram as preocupações no controle da venda e do uso de medicamentos, com a ciência de autoridades responsáveis pelas práticas de químicos e droguistas. Ao mesmo tempo, a legislação daquele momento considerava, em sua maior parte, positivas as práticas dos químicos e droguistas na saúde inglesa, especialmente no início do século XIX (Public General Acts, 1815). Frente a estes embates dentro do próprio Parlamento, caminhavam em paralelo as discordâncias de outros profissionais de saúde quanto aos privilégios dos químicos e droguistas, que trouxeram modificações importantes para a sociedade que estava acostumada a buscar 
as práticas médicas dos químicos e droguistas. É destes outros profissionais, os cirurgiões e os apotecários, portanto, que vamos continuar a falar em mais detalhes.

\subsection{Cirurgiões}

Assim como os químicos e droguistas, os cirurgiões foram outra classe que atuou como cuidadores da saúde. Os cirurgiões, em conjunto com médicos e apotecários $^{28}$, foram responsáveis por proporcionar conselhos médicos, incentivados por ações governamentais antes do século XIX (Remarks on Medical Reform, 1843).

O papel destes profissionais foi, primeiramente, concentrado na concessão do conselho médico, mas também trabalharam com a manipulação de fórmulas. As atividades como fazedores de medicamentos elevaram-se, especialmente após a fundação do Colégio Royal de Cirurgiões em 1843. Ganhavam poder 'duplo’ na área de saúde, atuando como curadores de doenças e fazedores de fórmulas medicinais. Graham (1827), um cirurgião, publicou uma tabela com os medicamentos mais comuns utilizados na medicina doméstica, expondo, inclusive, suas dosagens. Explicou ainda que para doses infantis, um paciente de catorze anos necessitava de aproximadamente dois terços da quantidade requerida para um adulto; se tiver sete anos de idade, metade da quantidade para o adulto; e assim sucessivamente:

Tabela 1. Tabela de medicamentos na medicina doméstica por um cirurgião inglês (adaptado de Graham, 1827, p. 557)

\begin{tabular}{|c|c|c|c|}
\hline Medicines & Adults & $\begin{array}{l}\text { oses } \\
\text { Children } \\
\text { From } 1 \text { to } 3 \text { Years }\end{array}$ & Proper Vehicle, \&c. \\
\hline Alkaline solution.......... & 1 to 3 drachms... & 20 to 60 drops...... & In water or beer, thrice a day \\
\hline Aloes (as a purgative)....... & 10 to 20 grains... & Not & In pills. \\
\hline $\begin{array}{l}\text {----- (as an alterative } \\
\text { and } \\
\text { stomachic)................ }\end{array}$ & $\begin{array}{l}\text { grain, thrice } a \\
\text { day................. }\end{array}$ & & ditto. \\
\hline $\begin{array}{l}--\ldots-\text {, compound tincture } \\
\text { of............................ }\end{array}$ & 1 to 5 drachms... & …................. & In water, thrice a day. \\
\hline ------, ethereal tincture of & 3 to 5 drachms... & 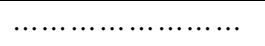 & ditto. \\
\hline $\begin{array}{l}\text { Alum, whether common or } \\
\text { burnt.................... }\end{array}$ & 10 to 20 grains... & ..................... & In water. \\
\hline
\end{tabular}

\footnotetext{
${ }^{28}$ Segundo Edler (2006), o período colonial no Brasil também foi composto destas três classes de profissionais - médicos, cirurgiões e apotecários: "Ocupando formalmente o ápice da pirâmide profissional, as três categorias, além de concorrerem entre si, mantinham um pendor regulamentar e vigilante sobre as atividades dos curadores especialistas em doenças dos olhos, cálculos urinários, hérnias etc." (p. 48).
} 
A função de fazer fórmulas pelos cirurgiões era apoiada pelos próprios químicos e droguistas, a despeito de todos os seus interesses pessoais e profissionais já mencionados. Naquele mesmo catálogo popular de medicamentos, o Hannay \& Dietrichsen's Almanack, químicos e droguistas destacaram o cuidado que os cirurgiões possuíam ao manipular, por exemplo, as pílulas do 'homem pobre', citando o nome de alguns cirurgiões importantes no período:

\section{Carefully Prepared by a Member of the ROYAL COLLEGE OF SURGEONS. As} several of the most eminent men in the English School of Medicine, namely, ARMSTRONG, BUCHAN, HUNTER, COOPER, ABERNETHY, SUDENHAM, CLARKE, and CRUIKSHANK have strongly recommended and prescribed this preparation of the POOR MAN'S PILL,... (Hannay \& Dietrichsen's

Almanack, 1842, p. B41, grifos nossos).

Diante destes benefícios em suas atividades, outros profissionais de saúde, como médicos e apotecários, sentiam-se ameaçados pelos cirurgiões. Uma das questões inseridas na reforma médica foram as modificações em suas funções ${ }^{29}$, argumentando-se que os cirurgiões não possuíam conhecimento suficiente para tratar de problemas de saúde (Remarks on Medical Reform, 1843), pois não eram indivíduos formados em universidades até o início do século XIX. Começaram a aprender sobre assuntos como anatomia e patologia somente após este período (Peterson, 1978). Os cirurgiões praticavam a cirurgia, a medicina e a farmácia sem licença, e que faziam suas pílulas sem seguir um livro de referência, vendendo-as a quaisquer pessoas que necessitassem desses medicamentos (Reports from Committees, 1856, p. 45-46).

É interessante a maneira como os cirurgiões atuaram nas artes de cuidar: atribuíam os problemas de saúde não somente a fatores internos do organismo, como também a questões externas, como o clima e a dieta. Um cirurgião chamado Sr. J. B. Davis escreveu, em 1836, um manual popular cujo conteúdo era baseado no bemestar pessoal, destacando sua relação com o meio ambiente: questões relacionadas à

\footnotetext{
${ }^{29}$ Em São Paulo, o controle governamental das atividades de cirurgiões iniciou-se com a organização do serviço sanitário no estado, com a separação das funções de médicos, cirurgiões e farmacêuticos. No artigo 32: "É absolutamente proibida a associação entre médico ou cirurgião e farmacêutico, para a exploração da indústria farmacêutica, sob qualquer forma." (Carvalho, 1892, p. 155).

No artigo 26: "Os médicos, cirurgiões, farmacêuticos, parteiras e dentistas, deverão matricular-se apresentando os respectivos títulos ou licenças na Diretoria de Higiene, afim de serem registrados." (Carvalho, 1892, p. 154).
} 
higiene, dieta, faculdades mentais, exercícios corporais etc. $\mathrm{O}$ manual não foi escrito somente para pessoas comuns, mas também para profissionais da saúde, conforme enfatizado na capa do livro: "Designed for the use of all ranks and professions in society."

Outro cirurgião escreveu uma enciclopédia com muitas 'dicas' sobre a medicina e a cirurgia domésticas, especialmente adaptadas para o uso popular. Apesar daquela formação inicial como aprendizes nas artes médicas, possuíam um conhecimento bastante restrito. Isso contribuiu para aumentar suas práticas médicas caseiras, 'adivinhando', muitas vezes, qual medicamento era o mais adequado para determinada doença (The Family Doctor, 1860, p. 96).

Com estas atividades 'médicas' se espalhando por toda a Inglaterra, criaram algumas inimizades não apenas com profissionais da área de saúde, mas também com pessoas de outras classes, onde não eram muito bem vistos especialmente pelas ordens religiosas. Um sermão publicado por um reverendo em 1794 mostrou os deveres de um hospital frente às necessidades dos pobres e ricos, e considerou que uma das questões dentro deste ambiente mais importantes era a 'gentileza' de um cirurgião, já que ele lidava com pessoas. O reverendo, na verdade, achava que tais profissionais não possuíam compaixão para lidar com doentes, não apresentavam boas maneiras de falar com um paciente. Acrescentou ainda que os cirurgiões excluíram a simpatia de sua personalidade, tão importante para o cuidado, mas que enganosamente achavam que a possuíam (Percival, 1794, p. 9).

Apesar de determinadas opiniões negativas sobre as atividades dos cirurgiões, muito fizeram para o desenvolvimento, por exemplo, dos dispensários, que eram instituições criadas para auxiliar pessoas pobres. Em meados do século XIX, houve um aumento no recrutamento de cirurgiões para trabalhar no dispensário de Brighton, uma cidade litorânea localizada ao sul da Inglaterra (A Letter to the Governors of the Brighton Dispensary, 1843). Algumas autoridades responsáveis pelos dispensários atentavam que os cirurgiões estavam sendo prejudicados financeiramente em decorrência de sua dedicação quase que exclusiva nestas instituições. Apontaram que esse prejuízo foi sanado, algumas vezes, com um pequeno desvio da verba destas instituições para atender às suas finalidades privadas (An Essay on Dispensaries, 1838, p.5-6).

Pouco a pouco, ganhavam espaço na saúde com suas habilidades profissionais e pessoais, modificando a forma como a sociedade inglesa da época trabalhava com 
as questões do cuidado à saúde. Estas transformações foram sentidas também com a reforma sanitária, onde cirurgiões atuaram, algumas vezes, como funcionários médicos. De certa forma, as atividades dos cirurgiões nas mudanças sanitárias trouxeram melhorias para a saúde pública do século XIX. Numa discussão sobre o cólera em 1832 da Comissão Sanitária Metropolitana do Parlamento, com presença de personalidades políticas importantes como Edwin Chadwick e o lorde Robert Grosvenor, o destaque foi para um cirurgião que atuava em prática geral na vizinhança de St. Giles. A Comissão atribuiu parte da melhora das condições de saúde da região a uma ação técnica dos cirurgiões, especialmente no que dizia respeito a melhorias ambientais. Alegaram que, apesar das tubulações para a drenagem da água não terem melhorado, houve o aumento da circulação de ar puro em St. Giles, o que diminuiria os riscos do cólera:

Have the late alterations improved the general health of the neighbourhood? - I shoud say yes, so far as we have now greater currents of pure air from above; but so long as these localities remain without sewers, and the present sewers remain as they are, I do not expect any permanent improvement. (Simpson, 1847, p. 33).

Não era uma melhora permanente, mas auxiliaria temporariamente o controle das doenças. Outra contribuição 'popular' na área de saúde dos cirurgiões foi a atuação deles em tempos de guerra. O cirurgião do exército Nikolai Pirogov trabalhou para curar doenças como o tifo, a fibre tifóide, o cólera e a disenteria na Guerra da Criméia, em adição ao seu pioneirismo no uso da anestesia nesta guerra ${ }^{30}$. Outro cirurgião, Sr. Benjamin Outram ${ }^{31}$ (1774-1856), da marinha, carregava em sua bagagem "...drawers and compartments containing scales, bottles for drugs, pestle and mortar and other medical equipment." Os cirurgiões foram os principais funcionários medicos à bordo, já que um navio de guerra poderia transportar um cirurgião ou um auxiliar de cirurgião para cada 200 tripulantes $^{32}$. De fato,

\footnotetext{
${ }^{30}$ Informação coletada da exposição "Guerra e Medicina" da Wellcome Library, Inglaterra. Acesso em 5 de fevereiro de 2009.

${ }^{31}$ Atuou na Batalha de Copenhagen em 1801.

32 A referência é proveniente da Coleção Lionel Foster, extraída da exposição no Museu Nacional Marítimo em Greenwich, Inglaterra. Acesso em 4 de fevereiro de 2009.
} 
During the wars there had been an increased need for naval and military surgeons, who were examined, before they would enter the Services, by members of the Court of Examiners. The examination for the Services had always been less stringent than that for the ordinary diploma, and it is likely that the standard was lowered owing to the great demand for surgeons while the war lasted. At the end of the war all surgeons who had served were allowed to start in civil practice without any further examination and the average standard of qualification was thereby lowered. (Cope, 1959, p. 42).

Os cirurgiões, nestas condições, exerceram um papel importante no cuidado com a saúde, mesmo com sua falta de conhecimento em medicina. Isso foi um aspecto importante na normatização de sua profissão ao longo do século XIX que teve conseqüências para a terapia popular: deixavam de ser homens sem reconhecimento legal na sociedade, deixavam suas funções 'populares' em diagnóstico e em manipulação de medicamentos, para abraçar uma legitimidade profissional proporcionada ao longo do século XIX. Seus conhecimentos populares sobre medicamentos e doenças abrangeram um campo vasto na saúde, e tais profissionais foram se apropriando desse caminho que trilhavam para ganhar espaço no meio profissional de saúde do século XIX inglês, disputando um lugar não somente com os químicos e droguistas, como também com outros profissionais da saúde, como os apotecários.

\subsection{Apotecários}

Da mesma forma que os cirurgiões, a função dos apotecários esteve ligada a um cruzamento de suas atividades nas áreas de medicina e de farmácia, que eram evidentes desde o século XVII.

Com a determinação do Ato dos Apotecários de 1815, tais profissionais ganharam um papel diferente na sociedade inglesa, com suas funções na área de saúde se moldando às exigências da população. Este ato introduziu o aprendizado obrigatório e as qualificações formais dos apotecários, sob a licença da Sociedade "Worshipful" dos Apotecários, sociedade cuja importância na trajetória das profissões de saúde tratamos mais adiante. A partir de 1815, os apotecários eram obrigados a possuir conhecimentos sobre anatomia, botânica, química, matéria médica e física, além de seis meses de experiência em hospital. $\mathrm{O}$ ato é importante porque mostrava o início da regulamentação para as profissões de saúde não somente na Inglaterra, como 
em toda a Grã-Bretanha (Porter, 1997, p. 316-317). Passavam a ser atores importantes não somente perante autoridades governamentais, como também frente a outros profissionais de saúde, como médicos e cirurgiões. Das bancadas de manipulação, foram parar nos consultórios médicos.

Ao longo dessa trajetória, porém, observou-se uma mistura de benefícios e de prejuízos para a sua profissão, até seu estabelecimento 'definitivo', com a regulamentação parlamentar por meio desse Ato de 1815. Por exemplo, antes do Ato dos Apotecários, foram submetidos a multas em caso de não seguirem o que estava determinado nas leis concernentes à produção de medicamentos (Public General Acts, 1815). Ao mesmo tempo, uma proteção legislativa permitia que não apenas apotecários, como também cirurgiões, químicos e droguistas, não fossem submetidos às taxações dos medicamentos antes de 1815. Essa regulamentação incluía tanto a preparação como o comércio de medicamentos:

Provided also, and be it further enacted, That nothing in this Act contained shall extend, or be construed to extend, to charge with the like Rates or Duties any Mixtures, Compositions, or Preparations whatsoever, mixed or compounded with or prepared from medicinal Drugs, medicated or chymical Denominations, or having different Properties, Qualities, Virtues, or Efficacies, which shall be uttered or vended by any such Surgeon, Apothecary, Chymist, or Druggist as aforesaid, or by any such Person who hath served as a Surgeon in the Navy or Army under any such Commission or Appointment as aforesaid,... (A Collection of the Public General Statutes, 1802, p. 500, grifos nossos).

Considerando a fase anterior a 1815, sua profissão passou por muitas mudanças do século XVII ao XIX. O século XVII foi marcado pela sua importância na arte de fazer fórmulas. É bem verdade que esta prática continuou com pouca intensidade durante os séculos XVIII e XIX, embora houvesse um desejo significativo destes profissionais em controlarem exclusivamente a manipulação de medicamentos (The Record of Pharmacy and Therapeutics, 1856, prefácio). Um livro publicado pelos apotecários já no século XIX continha a descrição de muitas fórmulas, somadas a seus usos comerciais na medicina e a importância destes medicamentos para profissionais como os médicos:

\section{Citrate of Protoxide and Peroxide.}


Ferro-Citrate of Iron.

Dose, 2 to 5 grains.

This citrate of iron has been though by some physicians to be highly valuable, especially in cases of tic-doloreux, which it is said to relieve when other ferruginous salts have failed. Theoretically, it is worthy of careful comparative experiments. (The Record of Pharmacy and Therapeutics, 1856, p. 18).

Os apotecários alegavam que a arte de fazer fórmulas era muito mais uma questão de 'dinheiro' do que de beneficiar a terapêutica da população. Exemplicaram esse interesse com a questão da adulteração do ruibarbo, uma planta medicinal: se o ruibarbo inglês fosse misturado ao turco ou do leste indiano, seria possível vender a "...twelve or sixteen shillings...", quando o valor verdadeiro seria de "...only worth three shillings..." (The Record of Pharmacy and Therapeutics, 1856, p. 34). Os apotecários queriam tanto se manter na manipulação e na venda de medicamentos pelo fato desta função trazer benefícios financeiros para os apotecários: possuíam não somente a permissão de cobrar por estas práticas, mas também de adquirir lucros elevados com o comércio.

Entretanto, não eram permitidos cobrar caso atuassem como conselheiros médicos (The Record of Pharmacy and Therapeutics, 1856, p. 216). Mas se envolveram nas práticas de conselho médico como forma de ganhar prestígio na sociedade inglesa da época. Um caso que mostrou a atuação dos apotecários nos conselhos médicos foi o ocorrido com o duque de Queensberry, que consultou, durante muitos anos, os serviços de seu apotecário, sem nunca pagar por isso. Após alguns anos, o apotecário,

...made a claim to the executors for $£ 10,000$ to cover 9,340 visits and 1,700 nights at the late Duke's house in Piccadilly. (DNB, 1811 citado por Hunting, 1998, p. 216).

Segundo ainda esta autora, o apotecário não conseguiu o montante reclamado. Este exemplo ilustra que o apotecário era um profissional que possuía certo reconhecimento na sociedade com seus trabalhos como conselheiro de doenças. Ao longo do século XIX, sua diminuição nas atividades de formular foi ganhando força por causa de problemas como a detecção de fraudes em drogas. Segundo o 
Parlamento inglês, químicos e droguistas eram os profissionais mais adequados a trabalhar com manipulação, mas não os apotecários: o argumento utilizado, bastante simplificado, foi o de que só visavam 'ganhar dinheiro' (An enquiry Into the Designs of the late Petition resented to Parliament by the Company of Apothecaries, 1748). Neste contexto, visualizamos um misto de interesses políticos, econômicos e sociais envolvidos, já que químicos e droguistas também desejavam seu enriquecimento pessoal quando faziam suas manipulações. Porém, havia outro interesse que impedia o desenvolvimento profissional dos apotecários junto ao dos químicos e droguistas. Talvez essa 'proteção' parlamentar para as atividades de químicos e droguistas tenha alguma lógica segundo o que Rumsey (2001) argumentou: pelo fato de químicos e droguistas serem os charlatães do povo, 'ignorantes' profissionais, não deviam ser punidos ou regulamentados, pois não possuíam culpa de sua própria 'ignorância' com medicamentos. Este autor acrescentaria ainda que se o povo já estava 'acostumado' com as artes populares dos químicos e droguistas, então não tinha motivo para 'trocar' o profissional envolvido - em nosso caso, os apotecários.

Com estas interrupções e entraves, os apotecários foram ganhando espaço no auxílio dos doentes pobres com seus conselhos médicos. Ainda praticavam a arte da manipulação, mas de modo bem insignificante:

The apothecary who became the general practitioner was one side of the coin. During the seventeenth century he began to move out of his shop and turned himself into a dispensing physician and later into the eighteenth century “surgeon-apothecary and man midwife”. (Holloway, 1991, p. 38)

Durante o século XIX, conseguiram credenciais do Colégio de Cirurgiões e da Sociedade dos Apotecários, e denominaram-se clínicos gerais; começaram a insistir no pagamento por seus conselhos médicos, e os fundos de suas casas tornaram-se suas ‘salas de cirurgia' (Holloway, 1991): a formação do médico clínico geral estava vinculada às atividades destes apotecários juntamente com os cirurgiões - o resultado foi a formação do 'cirurgião-apotecário', um misto de práticas em medicina e farmácia. Basicamente, iniciava-se muito jovem como um aprendiz, como parte do treino médico; depois, aprendia alguns conceitos em farmácia, medicina e comércio (Loudon, 1992). 
Os clínicos gerais não tiveram um largo conhecimento médico. Entretanto, tornaram-se o 'médico da família' ao longo do século XIX: iam às casas das pessoas doentes para examiná-las, dando conselhos médicos (Loudon, 1992). O Movimento de Registro de Doutores durante o ano de 1820, coordenado por Thomas Wakley, membro líder, e o Sr. Warburton, membro do Parlamento, decidiram incluir os clínicos gerais como parte da classe médica. A intenção foi a de abolir a separação das classes em três ordens, os médicos, cirurgiões e apotecários (Parry \& Parry, 1976). Mais tarde, houve um aumento na importância dos clínicos gerais (Remarks on Medical Reform, 1843). Esses debates governamentais e entre os próprios profissionais de saúde levaram a regulamentação da profissão do apotecário por meio de sua conversão em um médico clínico geral, que trouxe a mudança daquela função de 'conselheiro popular' para um 'conselheiro' legitimado pelo Parlamento. Mas não foram somente apotecários, químicos e droguistas, e cirugiões que trouxeram mudanças para as artes de cura populares: farmacêuticos também foram profissionais de saúde que influenciaram principalmente nas modificações das artes de fazer fórmulas e do comércio de medicamentos. O próximo capítulo tratou das atribuições de farmacêuticos ao longo do século XIX na Inglaterra. 


\section{Farmacêuticos em São Paulo e na Inglaterra}

\subsection{Na Inglaterra}

Foi a partir da trajetória de todos estes profissionais que os farmacêuticos, responsáveis pela manipulação e venda de fórmulas, começaram a se destacar na Inglaterra: as mudanças nas funções dos apotecários, em meio às brigas com os químicos e droguistas, mais o exercício de fazedores de medicamentos dos cirurgiões - tudo isso em conjunto, criou condições para o estabelecimento da profissão farmacêutica ao longo do século XIX inglês, trazendo mudanças no escopo da terapia popular com medicamentos. Tais modificações ganharam força a partir do momento em que se evidenciou a necessidade de se prover educação universitária para os químicos e droguistas. Ademais, o desenvolvimento da química proporcionava a emergência do "pharmacien" com conhecimento em química prática: era o surgimento, ainda discreto, do farmacêutico químico.

Neste contexto, um Ato importante, o Ato Farmacêutico de 1852, foi aprovado para reavaliar a função dos químicos e droguistas, do químico dispensador e também do farmacêutico químico, três denominações dadas para a função do manipulador e vendedor de drogas àquela época (Holloway, 1991). Cabe aqui uma observação para facilitar o entendimento das denominações para o profissional em farmácia ao longo do capítulo. O farmacêutico hoje é reconhecido na sociedade inglesa, segundo Merrills \& Fisher (2001), por determinados títulos profissionais restritos à sua profissão. Somente farmacêuticos podem utilizar ou serem chamados pelos seguintes títulos: farmacêutico, farmacêutico químico, "pharmaceutist", membro ou "fellow" 33 da Sociedade Royal Farmacêutica (p. 87).

Assim, este ato de 1852 tinha como objetivo principal regulamentar as atividades dos chamados farmacêuticos químicos, estabelecendo diretrizes para o registro destes profissionais, elevando sua qualificação por meio de exames e emissão de diplomas, controlando eventuais falsificações nos registros, e punindo os profissionais em caso de fraudes na profissão (Pharmacy Act, 1954, p. 1-19).

Em realidade, tal Ato se passou porque os interesses profissionais de cada um destes grupos chegaram a um ponto em que não era mais possível aceitar, principalmente, os lucros de químicos e droguistas advindos com o comércio de

\footnotetext{
33 A tradução para este termo que mais se aproxima no Brasil é "pesquisador'. O termo "fellow" também é comumente usado para titular jovens professores de universidades, que ainda estão ‘ascendendo' na carreira universitária.
} 
drogas e especiarias (Hannay \& Dietrichsen Almanack, 1842). Os Atos Gerais Públicos (1815) também estabeleceram normas de proteção para tal comércio. Adicionalmente, apotecários, por exemplo, reclamavam que davam conselhos médicos 'gratuitamente' (Hunting, 1998; The Record of Pharmacy and Therapeutics, 1856). Nesta mistura de funções, tanto o comércio de medicamentos como as práticas dos conselhos médicos aconteciam de modo ordinário, conduzido até mesmo por indivíduos de formação simples, como os comerciantes de armazéns ${ }^{34}$. Tal Ato Farmacêutico se passou, então, para definir legalmente quem eram os responsáveis pelas funções de farmácia. Muito da determinação desse ato aconteceu para atender às 'confusões' pessoais profissionais de cada um deles na sociedade inglesa, especialmente de ordem econômica. A determinação deste ato mudaria os caminhos das normas para as artes de formular, principalmente no que dizia respeito aos manipuladores de medicamentos.

O Ato Farmacêutico de 1852 foi criado principalmente em decorrência dos interesses de Jacob Bell, um dos mais importantes farmacêuticos britânicos no século XIX. Segundo Holloway (1991), somava um misto de inteligência e ganância profissional, lutando pela melhora do campo farmacêutico, em conjunto com seus próprios interesses.

Era filho de John Bell e Eliza Smith. De acordo ainda com esse autor, “Jacob Bell was born into a world of pharmacy and Quakerism." (p. 1). Herdou a loja de seu pai na Rua Oxford em Londres, o qual foi aprendiz do pai de Eliza Smith. Sua mãe era filha de um químico e droguista, dono de uma loja em Haymarket, Londres. Jacob Bell não apenas apresentou interesse em farmácia, mas também em artes e literatura. Assistiu a aulas em química, somado a seu interesse em anatomia. Era um homem de personalidade forte, e dedicou-se muito para o estabelecimento da Sociedade Farmacêutica Royal da Grã-Bretanha em 1841. Foi também o editor do periódico Pharmaceutical Journal de 1844 a 1853 (Holloway, 1991).

Bell defendeu a área de farmácia, argumentando que precisava ser protegida de indivíduos charlatães, especialmente dos químicos e droguistas. Foi Jacob Bell quem suscitou a importância de 'ensinar' os não-qualificados nas artes farmacêuticas por meio do ensino em farmácia. De fato,

\footnotetext{
${ }^{34}$ Em Public General Statutes, 1812, p. 1351 e Public General Acts, 1815, p. 1743.
} 
The memorial which was prepared contained a brief and appropriate exposition of the importance of Pharmacy to the health and life of his Majesty's subjectsthe necessity of education and integrity in those whose duty it is to carry into effect the instructions of medical men-the prevalence of ignorant and incompetent persons calling themselves Chemists and Druggists, and the frequency of injury to the public from this source-the difficulty of detecting adulterations and the necessity of proper qualification in pharmaceutists, in order to enable them to perform their duty in this respect- (...) the danger arising from the uncontrolled sale of poisons by ignorant persons;... (Bell, 1843, p. 56, grifos nossos).

Mostrou também preocupação nos caminhos que seguiam a profissão farmacêutica, enfatizando que os membros da Sociedade Farmacêutica deveriam basear seus trajetos profissionais por meio dos passos que tomaram os 'antigos' apotecários: pedia que os farmacêuticos tomassem a experiência de seus 'antecessores' para alcançar a 'sabedoria' farmacêutica, evitando, principalmente, os erros cometidos por eles (Bell, 1843, p. 108).

Segundo Holloway (1991), Bell enfatizou que os únicos indivíduos que poderiam vender drogas eram aqueles providos de educação sobre medicamentos, pois passaram por um estudo sobre a natureza e as propriedades das substâncias terapêuticas. Argumentou que a venda de medicamentos contaminados, por exemplo, por "...chandlers, grocers, oilmen, drapers and small shopkeepers..." (p. 214), precisava ser combatida. Chamava-os de “...ignorant and an uneducated person...” (p. 214).

O Ato de 1852 dava destaque principalmente para o papel do farmacêutico químico, que misturava os conhecimentos químicos às artes farmacêuticas. Conforme este autor aponta:

...raise the character of pharmaceutical chemists. It would oblige all those who regularly follow the business to learn the rudiments of chemistry and the collateral sciences....”. “...The majority, however, would confer a benefit on the public in another way, by performing in a more safe and efficient manner the duties of pharmaceutical chemists in the preparation of medicines, many of which are powerful poisons, and ought not to be entrusted in the hands of ignorant and inexperienced persons. (Holloway, 1991, p. 167, grifos nossos). 
De fato, durante o reinado da rainha Vitória decretou-se um Ato regulamentando as qualificações somente destes profissionais,

...to prevent ignorant and incompetent Persons from assuming the Title of or pretending to be Pharmaceutical Chemists or Pharmaceutists in Great Britain, or Members of the said Pharmaceutical Society, and to that end it is desirable that all Persons before assuming such Title should be duly examined as to their Skill and Knowledge by competent Persons, and that a Register should be kept by some legally authorized Officer of all such Persons... (Public General Acts, 1852, p. 489-490).

Punia-se assim indivíduos que assumissem o título de farmacêutico químico por meio do pagamento de multa equivalente a cinco libras esterlinas (Public General Acts, 1852, p. 493).

Apesar destes esforços, os profissionais farmacêuticos também sofreram resistência das mesmas autoridades governamentais que os apoiavam, pois eram confundidos com indivíduos sem a qualificação requerida: da mesma forma que Jacob Bell atentava para o exercício dos 'charlatães ingleses', as autoridades responsáveis alegavam que era preciso elevar o controle legislativo sobre a venda de medicamentos e os manipuladores de drogas por meio desse ensino teórico em farmácia. Este ensino iniciou-se por intervenção das secretarias locais nas províncias, que se responsabilizaram por reunir indivíduos comuns da própria sociedade inglesa para assinar um abaixo-assinado contra tais práticas dos populares charlatães (Holloway, 1991, p. 150-151).

A população, de fato, mostrava certo receio sobre os conhecimentos técnicos destes farmacêuticos. Um pintor retratou a figura de um farmacêutico através do desenho de um indivíduo semelhante a um bruxo cadavérico, fazendo medicamento em um grande pote. Acrescentou, neste pote, as escritas ARSÊNICO, de um lado do quadro, e 'PLASTER of PARIS ${ }^{, 35}$ do outro lado (s.n., 1858) ${ }^{36}$. Ao mesmo tempo em

\footnotetext{
${ }^{35}$ É o gesso na tradução para o português. Segundo a Enciclopédia Britânica, o "Plaster of Paris" é assim chamado porque o gesso foi utilizado nas redondezas de Paris para fazer cimento e gesso em pó. Disponível em: http://www.britannica.com/EBchecked/topic/463673/plaster-of-paris. Acesso em 21/11/2009.
} 
que evidenciavam as mudanças na área farmacêutica, especialmente com a diminuição de atuação de químicos e droguistas, associavam o farmacêutico a um indivíduo meio 'feiticeiro', que curava as pessoas mas não compreendiam muito bem seus métodos aplicados (Hunting, 1998).

Valendo-se dessas incertezas, o Parlamento voltou seus esforços para o controle do comércio e do uso de medicamentos, bem como dos profissionais envolvidos nestas atividades. Somado ao exercício de pessoas não-qualificadas, havia o problema da adulteração de drogas, e todas as ações envolvidas nesta prática (Reports from Committees, 1855, 1856).

Neste sentido, a regulamentação foi reforçada com a taxação dos medicamentos ${ }^{37}$, chamados de medicamentos comerciais e patenteados. A definição de medicamentos comerciais e patenteados foi relacionada àqueles medicamentos que eram produzidos com substâncias desconhecidas, não seguiam um livro de referência, não eram regularmente prescritos para uso de um profissional médico, e eram comercializados por quaisquer pessoas (Farmer v. Glyn-Jones, 1903 citado por Booth, 1990, p. 337). Já os medicamentos cuja produção seguia um livro de referência podiam ser comercializados somente pelos farmacêuticos (Bell, 1843).

Assim, o Ato de 1802 considerou como medicamentos todas as drogas, ervas, águas, pílulas, essências, tinturas e pós. No entanto, somente as drogas não foram submetidas à taxação porque sua manufatura era baseada segundo um livro de

\footnotetext{
${ }^{36}$ Não houve disponibilização para fotocopiar a pintura. Arquivo iconográfico da Wellcome Library, "Death as a lethal pharmacist making up medicines using arsenic and plaster of Paris as ingredients." Wood engraving, 1858, n. $47061 \mathrm{i}$.

${ }^{37}$ Impostos na área de saúde começaram a existir no final do século XVIII. O primeiro imposto em medicamentos foi introduzido em 1783 por meio de um Ato que visava controlar a venda de medicamentos e também as pessoas envolvidas nesta transação (Champion et al., 2004). Durou até 1785, quando o reinado revogou o mesmo, criando o Ato de 1785. Após este Ato, o reinado de George III começou o século XIX com outra anulação e consequente substituição do Ato anterior pelo Ato de 1802: neste Ato, todos os impostos determinados em 1785 foram excluídos, surgindo novas tarifas para a manipulação e dispensação de medicamentos patenteados e comerciais. Após este Ato, outros três ainda foram decretados durante o reinado de George III. O Ato de 1803 Act foi uma emenda do Ato precedente, reforçando o controle dos indivíduos que trabalhavam em quaisquer atividades relacionadas à preparação e à venda de medicamentos. Seguindo estas mudanças, o Ato de 1804 consolidou o Ato de 1802: o estabelecimento de impostos para indivíduos sem licença e também a taxação dos medicamentos (Booth, 1990). Finalmente, a última mudança na taxação de medicamentos aconteceu com o Ato de 1812. Após este Ato, o reinado da rainha Vitória emendou os dois Atos anteriores para responder às mudanças na sociedade britânica. O Ato de 1853 modificou as taxas para os profissionais de saúde. Para maiores informações, consultar: A Collection of the Public General Statutes, 1802, 1803, 1812; Public General Acts, 1853.
} 
referência. Tais drogas já eram submetidas a taxações que se iniciaram no final do século XVIII. Desta forma, os impostos a partir deste ato de 1802 ficavam à cargo desses medicamentos comerciais e patenteados, uma vez que a produção dos mesmos não seguia nenhum livro técnico de referência (A Collection of the Public General Statutes, 1802, p. 499). Abaixo, um exemplo de um medicamento incluído na lista de remédios sujeitos à taxação:

\author{
Waters, videlicet - All artifical Mineral \\ with Soda or Mineral Alkali, or \\ with Carbonic Acid Gas, and all \\ Compositions in a liquid or solid \\ State, to be used for the Purpose of \\ Compounding or making any of the
}

Said Waters. (A Collection of the Public General Statutes, 1803, p. 1357) ${ }^{38}$.

Quase dez anos depois, o Parlamento incluiu, no Ato de 1812, outros medicamentos sujeitos à taxação, assim como destacou uma multa para a maior parte dos indivíduos que vendiam medicamentos sem o cumprimento das especificações determinadas pela Comissão de Selos (A Collection of the Public General Statutes, 1812).

Em 1856, o Comitê encarregado pelo controle de medicamentos ilegais sugeria a cobrança de uma taxa maior sobre estes artigos. Alegavam que as taxas cobradas encontravam-se desproporcionalmente fora dos preços dos medicamentos desde 1853, o que levava à quase ausência de proteção destes produtos (Reports from Committees, 1856, p. 235).

A despeito dos impostos cobrados sobre grande parte das pessoas envolvidas nesse comércio, o último Ato Geral de Impostos sobre medicamentos, estabelecido em 1812, apresentou uma exceção à regra: os indivíduos de armazéns, vendedores de uma diversidade de mercadorias, além dos medicamentos caseiros medicinais, não precisavam pagar impostos; mas precisavam de uma licença governamental para atuar no comércio de seus produtos. Estes homens atuaram, muitas vezes, como terapeutas

\footnotetext{
${ }^{38}$ A soda ou os minerais alcalinos, assim como o ácido carbônico, possuem propriedades que levam à melhora de sintomas gástricos leves.
} 
populares, vendendo substâncias medicinais (Holloway, 1991). De acordo com a seção IV:

Provided always, and be it enacted, That it shall not be necessary for any Victualler, Confectioner, Pastry Cook, Fruiterer, or other Shopkeeper in Great Britain, who shall only sell any of the artificial or other Waters mentioned in the Schedule hereunto annexed, to be drank in his or her House or Shop, and which shall be actually drank therein, to take out a Licence for that Purpose under the Provisions of the said Acts of the Forty-second and Forty-fourth Years of His Majesty's Reign, provided such Waters shall be sold by him or her in Bottles with Paper Covers, Wrappers, or Labels duly stamped, properly and sufficiently pasted, stuck, fastened, or affixed to the same in the Manner hereinbefore mentioned; any Thing in the said Acts contained to the contrary notwithstanding. (A Collection of the Public

General Statutes, 1812, p. 1351, grifos nossos).

De fato, estas águas mencionadas na citação acima eram consideradas como possuidoras de propriedades medicinais 'leves', portanto, com funções terapêuticas. Neste contexto, a atitude do governo britânico ao permitir a venda destes produtos em ‘quaisquer' casas, por 'determinados' indivíduos, dava margem para o exercício de populares que não possuíam ligação profissional com a área de saúde. Se o objetivo 'único' das autoridades era o de controlar os 'riscos' no uso de substâncias farmacêuticas por meio da taxação das mesmas, havia interesses maiores somados à preocupação com a saúde da população. Estas águas e outros compostos, bem como as práticas de pessoas não-habilitadas, continuaram aprovadas nos estatutos britânicos ainda em 1915, quando aconteceu nova reformulação na taxação sobre os medicamentos, já sobre pressões da Primeira Guerra Mundial (Booth, 1990).

Ao lado daqueles comerciantes de armazéns, os indivíduos sem habilitação técnica para produzir e comercializar medicamentos, mas que atuavam exclusivamente na área de saúde, deveriam também possuir uma licença para o preparo e a venda desses medicamentos. De acordo com a seção VI:

And be it further enacted, That every Owner, Proprietor, Maker, and Compounder of, and every Person in Great Britain, uttering, vending, or exposing to Sale, or keeping ready for Sale, any such Drugs, Herbs, Pills,

Waters, Essences, Tinctures, Powders, or other Preparations or 
Compositions whatsoever, used or applied or to be used or applied externally or internally as Medicines or Medicaments, for the Prevention, Cure, or

Relief of any Disorder or Complaint incident to or in anywise affecting the human Body, or any Packets, Boxes, Bottles, Pots, Phials, or other Inclosures aforesaid, with any such Contents as aforesaid, subjected to the Duties hereinbefore granted, shall annually take out a Licence;... (A Collection of the Public General Statutes, 1802, p. 500, grifos nossos).

Estes indivíduos esforçaram-se para possuir a licença, pois o comércio de medicamentos patenteados foi bastante lucrativo: conforme relato de um desconhecido, que possuía bastante experiência no comércio de medicamentos patenteados, costumava falsificar os selos de medicamentos, em geral colocando valores de selos inferiores ao que de fato valia o produto (Reports from Committees, 1856, p. 234).

Assim, tirar a licença 'profissional' era obrigatório, mas os impostos não incidiam sobre todas as 'profissões', somente sobre os produtos comercializados por estes 'profissionais'. Neste sentido, caso uma pessoa não pagasse o imposto sobre o medicamento, seria multada com o pagamento de 20 libras esterlinas ${ }^{39}$. Além disso, estes indivíduos precisavam submeter todos os rótulos dos medicamentos produzidos e vendidos à Comissão de Selos (A Collection of the Public General Statutes, 1802).

Nestas condições, tudo indica que havia uma divisão no controle governamental sobre os medicamentos e os indivíduos envolvidos com eles. De um lado, as regulamentações sobre indivíduos, em geral sem qualificação técnica, que detinham o controle sobre os medicamentos comerciais e patenteados, e a taxação em cima de seu comércio ${ }^{40}$; de outro lado, os farmacêuticos, que ganhavam legitimidade na área de farmácia.

É provável que o farmacêutico da Inglaterra de hoje não existia antes de seus embates com os químicos e droguistas. Tudo indica que a profissão farmacêutica de fato 'originou-se' das atividades dos químicos e droguistas. O farmacêutico foi denominado de químico até a Primeira Guerra Mundial, onde houve algumas

\footnotetext{
${ }^{39}$ Uma libra esterlina àquela época vale hoje setenta vezes menos em relação à libra atual. Disponível em: http:www.victorianweb.org/economics/inflation.html. Acesso em 21/11/2009.

${ }^{40}$ Conforme apontamos, estas taxações sobre os medicamentos comerciais e patenteados começaram já em 1802 e vigoraram durante todo nosso período de análise determinado (1815-1858), por isso a necessidade de se detalhar tais atos, mesmo que estabelecidos em um período anterior ao Ato dos Apotecários de 1815. Estes atos foram a base para compreender o que acontecia com o comércio de medicamentos, bem como das pessoas envolvidas nesta atividade.
} 
tentativas de se substituir a nomenclatura 'químico' por 'farmacêutico'. Muitas drogarias britânicas ainda mantém o usual "chemist's shop" em suas fachadas ${ }^{41}$.

Conjuntamente, passavam por fiscalizações no exercício de suas práticas, e dos produtos 'farmacêuticos' que se utilizavam. Ao mesmo tempo, farmacêuticos ganhavam poder para exercer, de maneira bastante privilegiada, os ofícios de manipulação e de comércio de medicamentos. 'Concorriam' entre si e ganhavam espaço no comércio de medicamentos. Eram basicamente interesses voltados para as necessidades comerciais do período, ditados pelo crescimento urbano e comercial (Bynum, 2006; Thomas, 1997).

Conforme Holloway (1991) aponta, somente farmacêuticos deveriam ter o acesso à venda desses medicamentos de referência. Por exemplo, a fiscalização em cima do uso do ópio nas primeiras décadas do século XIX foi reforçada pelo Ato do Ópio. As taxas de morte por overdose foram um dos fatores que influenciaram na restrição do uso desta droga. O Gabinete Geral de Registro, criado em 1837, foi uma agência responsável por veicular dados de saúde pública e de medicina relacionados ao uso do ópio (Berridge, 1999). O láudano, um medicamento derivado do ópio, foi criado por Thomas Sydenham no século XVII. De acordo com Hodgson (2001), especialmente de 1664 a 1868, a Corte Inglesa, os escritores, os pintores e a população em geral utilizavam esta droga para curar dores em geral. Era facilmente conseguida em muitas casas medicinais, elevando o auto-cuidado, e também as taxas de morte.

John Swift, um médico otologista ${ }^{42}$ 'popular' que exercia suas funções na cidade de Huddersfield, costumava administrar láudano para bebês com o intuito de mantê-los em silêncio. Sua agenda foi encontrada e publicada, com relatos do período de 1784 a 1851 de todas as suas charlatanices (Stead, 2002). Isto também ocorreu em Manchester, com 13.362 mortes de bebês. Nas palavras do autor: "Consequently the babies became addicted, didn't feed, shrivelled and died." (p. 108).

Em paralelo, o surgimento do Ato do Arsênico de 1851 também destacou a importância da atuação do farmacêutico químico determinada no Ato Farmacêutico de 1852. Muitas pessoas morreram envenenadas, além do número elevado de suicídios

\footnotetext{
${ }^{41}$ Consultar: Sonnedecker, G. Seção “Glossary”. In: Kremer's and Urdang's History of Pharmacy. Estados Unidos da América: American Institute of the History of Pharmacy, p. 449, 1986. Disponível em: http://books.google.com.br/books?id=r__FmMNS7qIC\&pg=PA117\&dq=pharmacy+britain\#v=onepag $\mathrm{e} \& \mathrm{q}=$ pharmacist $\% 20$ britain $\& \mathrm{f}=$ false. Acesso em 09/11/2009.

${ }^{42}$ Médico que cuida de problemas auriculares.
} 
com arsênico. Em meados de 1849-1850, houve uma recomendação da Sociedade Farmacêutica e da Associação Provincial Médica e Cirúrgica que apenas médicos e farmacêuticos, da mesma maneira que fizeram com o controle do ópio, deveriam vender esta droga (Holloway, 1991, p. 180).

\subsection{Em São Paulo}

O olhar histórico que adotamos para investigar os profissionais farmacêuticos em São Paulo mostrou-se bastante diferente daquele que vimos na Inglaterra. O período da Primeira República não mostrou uma trajetória destes profissionais ligada aos outros profissionais de saúde, os químicos e droguistas, os apotecários e os cirurgiões. Talvez esta relação com os outros profissionais de saúde tenha acontecido ainda no período imperial, mas seria preciso outra investigação para afirmar essa suposição. Uma semelhança, entretanto, foi encontrada na área farmacêutica quando investigamos a questão relacionada à manipulação, ao comércio e ao uso de medicamentos. As preocupações governamentais nestes três itens eram semelhantes, embora partissem de pontos diferentes - na Inglaterra, a preocupação era com aqueles medicamentos comerciais e patenteados, conforme já apontamos, e em São Paulo, especialmente com as matérias-primas utilizadas para produzir os medicamentos, suas falsificações, bem como as fraudes de medicamentos. A produção de medicamentos aqui dava seus primeiros passos, e o fortalecimento da indústria farmacêutica seria observado somente após a Segunda Guerra Mundial (Bermudez, 1995). Este inicial desenvolvimento da indústria de medicamentos no estado de São Paulo, atrelado à trajetória dos farmacêuticos, é que tentamos tratar ao longo deste capítulo. Assim, vamos iniciar nossa análise dos caminhos percorridos pelos farmacêuticos paulistas dando uma breve exposição sobre como eram 'classificados' os ofícios dos profissionais em farmácia no Brasil.

Até 1894, havia os farmacêuticos diplomados e os práticos em farmácia, onde estes últimos podiam exercer os ofícios da farmácia 'a título precário', pois não possuíam o diploma de farmacêutico. Segundo Edler (2006), ambos podiam exercer as atividades farmacêuticas como “....a elaboração de medicamentos e a administração das farmácias...” (p. 110) sob uma licença governamental. Porém, tal permissão para os práticos em farmácia gerava atrito entre os farmacêuticos diplomados, que queriam a exclusividade no trabalho com os medicamentos, e “...a concessão desse tipo de 
licença seria reduzida ao prazo de dez anos, em 1890, e definitivamente abolida em 1894." (p. 110).

Com a criação da Escola Livre de Pharmacia em 1898 em São Paulo, o exercício dos farmacêuticos diplomados passou a ser reconhecido oficialmente por meio dos cursos para farmacêutico; mas havia também o curso para os práticos de farmácia. A diferença era o tipo de título que cada um recebia - farmacêuticos ganhavam um 'diploma', e os práticos em farmácia, uma 'certidão de habilitação'. Outra diferença é que os dois profissionais contribuíam no orçamento do estado de São Paulo por meio do pagamento de um imposto pela finalização de seus estudos, chamado de selo estadual, mas práticos pagavam $20 \$ 000^{43}$, e farmacêuticos, $50 \$ 000$. Estes últimos ainda pagavam mais $60 \$ 500$, referentes ao selo federal de seu diploma (Mello Filho, 1909, p. 37).

Havia também o papel dos boticários, indivíduos que eram 'confundidos' pela população com os farmacêuticos diplomados. De acordo com Edler (2006), as atividades dos boticários duraram até o século $\mathrm{XX}$ - muitos proprietários de boticas, a maioria constituída pelos práticos em farmácia, ou “...meros comerciantes ou cirurgiões-barbeiros que se associavam a farmacêuticos...” (p. 67), “...pagavam farmacêuticos para dar nome a seus estabelecimentos..." (p. 67). ${ }^{44}$

Neste sentido, a criação da escola de farmácia beneficiaria os profissionais farmacêuticos, criando um ambiente propício para o desenvolvimento do ensino em farmácia e, consequentemente, das atividades de manipulação, de comércio e de uso de medicamentos. Isto traria mudanças nas práticas em farmácia de terapeutas populares no período da Primeira República, já que farmacêuticos ganhavam espaço na saúde pública por meio desse reforço no ensino técnico farmacêutico. O farmacêutico F. B. D. ${ }^{45}$ (1899), discorrendo sobre os benefícios da escola, argumentou que os jovens farmacêuticos que ingressassem no curso de farmácia iriam:

\footnotetext{
${ }^{43}$ Segundo Martins (2003), um real hoje equivaleria a 2 trilhões e 750 bilhões de contos de réis (2 750000000000 000\$000) (p. 105). Consultar: Cédulas Brasileiras do Mil-Réis ao Real. Sociedade Numismática Brasileira, ed. n. 54, p. 104-114.

${ }^{44}$ De acordo com o mesmo autor, havia a lei de 3 de outubro de 1832 no período imperial. Tal lei proibia os boticários de exercerem as artes de cura na ausência do diploma expedido pelas faculdades de medicina. Entretanto, esta regulamentação não impediu que os boticários trabalhassem com os oficios em farmácia.

${ }^{45} \mathrm{O}$ nome por extenso do farmacêutico F.B.D. não foi encontrado nos arquivos consultados.
} 
...estabelecer lucta franca e vantagiosa contra os charlatães que ahi já

mercadejam com filbusterios, crêar um elemento indispensavel para a vida e progresso de qualquer localidade (p. 170).

Alguns anos depois, outro farmacêutico também destacaria a importância do ensino em farmácia, alegando que os farmacêuticos eram os responsáveis pelo controle das atividades desses terapeutas do povo. Em suas palavras: "O exercicio illegal da pharmacia por individuos não diplomados nem licenciados, com a responsabilidade de pharmaceuticos..." “...são outros pontos contra os quaes se baterá..." (Queiroz, 1902, p. 3). Na verdade, durante todo o período da Primeira República os farmacêuticos demonstraram bastante vontade de combater as práticas de pessoas não diplomadas, e o estabelecimento desta escola de farmácia foi apenas uma dentre outras pressões feitas em cima de autoridades governamentais, as quais contribuíram para a luta destes profissionais contra o exercício das práticas populares.

Esse misto de farmacêuticos, práticos em farmácia e terapeutas populares acabava prejudicando as atividades de saúde ligadas à área de farmácia frente à população paulista. Segundo Costa (1895), a população mostrava seu desconhecimento acerca das habilidades de pessoas que trabalhavam no ramo farmacêutico, onde os próprios profissionais farmacêuticos discutiam entre si o que a população pensava sobre a sua classe. $\mathrm{O}$ autor apontou descrédito do poder público e da população frente às funções de farmacêuticos. Muito dessa desconfiança acontecia por conta da falta de confiança nos produtos farmacêuticos nacionais, com o medicamento estrangeiro sendo mais confiável pela sociedade paulista da época. Costa aludia à falta de incentivo governamental quanto à utilização e análise de substâncias nativas: "Tivessemos protegido a nossa industria..." (p. 69).

O desenvolvimento industrial em São Paulo começou a dar seus primeiros passos durante o período da Primeira República, e a participação dos farmacêuticos no desenvolvimento do ramo industrial foi importante porque foram eles os profissionais que estiveram de frente no controle das matérias-primas utilizadas na fabricação das drogas, bem como na produção, na venda e no uso destas drogas. Alguns nomes de destaque foram os de Virgilio Lucas, Coriolano Carvalho, Octavio dos Anjos, Cândido Fontoura (Primeiro Congresso Brasileiro de Pharmacia, 1922). Dentre eles, Fontoura foi um dos farmacêuticos mais importantes na época republicana. Proveniente de Bragança, interior de São Paulo, chegou à cidade em 1915 com o 
objetivo de se desenvolver mais no ramo farmacêutico. Conseguiu isto não somente por seus anseios pessoais, mas também por obter apoio de personalidades ligadas ao serviço sanitário de São Paulo. Almejava, dentre outras coisas, lançar um medicamento contra o amarelão, doença muito comum naquela época, especialmente na zona rural: "Persistiu na luta, e o destino, pela mão de um amigo, approximou-o da captivante pessôa de Guilherme Alvaro, então Director do Serviço Sanitario. Deulhe o illustre hygienista a incumbencia da preparação de comprimidos de naphtolbeta para a campanha contra o amarellão. Nasceu assim a "Ankilostomina Fontoura" que se tornou logo um valioso producto, de largo emprego em todo o paiz." (Sciencia Medica, 1927, p. 545).

Segundo Edler (2006), Fountoura demonstrava interesse pelos problemas sanitários vigentes na época, especialmente os associados a doenças. A criação do então conhecido Biotônico Fountoura pouco antes de 1910 mostrou a preocupação deste farmacêutico, que o criou após seu uso para o tratamento de uma doença de sua esposa:

O remédio foi batizado de Biotônico Fontoura, por sugestão de Monteiro Lobato, seu colega de trabalho no jornal O Estado de S. Paulo, onde Fontoura colaborava com escritos no campo das ciências. Fontoura havia indicado o remédio ao colega, que reclamava de fraqueza. Lobato utilizou$o$ e sentiu-se revitalizado. Animado com o produto, ele criaria o “Almanaque do Jeca Tatu”, como peça de marketing para o Laboratório de Fontoura. O almanaque de Lobato divulgava ao público como se dava o ciclo de infestação pelo ancilostoma e os sintomas da ancilostomose, ensinando medidas de educação sanitária para a proteção contra a doença. ... Em suas páginas o Jeca Tatu era apresentado como um caboclo, magro, fraco, triste e preguiçoso que se tornava saudável e ativo obedecendo às medidas sanitárias e utilizando o Biotônico Fontoura. (Edler, 2006, p. 97). 46

\footnotetext{
${ }^{46}$ Conforme apontam Lima \& Hochman (2000), o Jeca Tatu era um símbolo do atraso social e econômico do país. Até meados de 1915, autoridades sanitárias e de saúde concentraram suas ações neste sentido, com o controle das atividades em saneamento e métodos de tratamento de enfermidades, por meio do trabalho de médicos e sanitaristas. Em um segundo momento da reforma sanitária, em torno de 1915, o movimento foi dirigido para o sanitarismo rural, em seqüência ao urbano, com a constatação de que o Brasil era um país doente, principalmente após os relatórios da expedição médicocientífica em 1912 de Artur Neiva e Belisário Pena, retratando as péssimas condições em que viviam os habitantes do interior do país. Ao mesmo tempo, Monteiro Lobato desconstruiu a imagem do personagem "Jeca Tatu" como um ser preguiçoso, ignorante e ocioso, criada por ele mesmo em período anterior, enfatizando que na realidade o problema deste personagem eram as doenças que o afetavam.
} 
Nestas condições, farmacêuticos foram personalidades importantes que atuaram nas modificações em saúde no estado de São Paulo, trabalhando no controle das doenças e dos medicamentos. Estes profissionais encontravam-se, de fato, inseridos nas mudanças legislativas da reforma sanitária de 1892. A profissão farmacêutica foi a que mais sofreu novas regulamentações quando suas funções profissionais são comparadas às de outros profissionais, e isto foi percebido pelas emendas na lei n. 43 de 18 de julho de 1892 ocorridas ao longo da Primeira República. De 1892 a 1930, o item "Do exercicio da medicina, da pharmacia, da obstetricia e da arte dentaria" apresentava, em geral, uma nova determinação legal quanto à profissão farmacêutica e, por outro lado, poucas novas regulamentações quanto à profissão de médico. Dentro destas novas especificações, a profissão farmacêutica passou por um misto de prejuízos e de benefícios, que andaram lado-alado durante todo o período da Primeira República.

Por exemplo, um farmacêutico reclamou às autoridades sobre as mudanças legislativas referentes ao trabalho de farmacêuticos nos estabelecimentos como as farmácias. Argumentou que a nova lei continuava a permitir a gerência de uma farmácia por qualquer pessoa, e que isso diminuía a importância dos profissionais farmacêuticos no comércio de medicamentos. Na nova lei determinada pelo serviço sanitário, os farmacêuticos queixavam-se da:

...injustiça desses deveres não virem acompanhados do mais elementar direito, de que ha tanto a classe reclama, isto é, que o farmaceutico seja o proprietario da farmacia que explora, salvo excepções muito bem previstas pela maioria das leis sobre farmacias....

Os emprestimos de nome para farmacia continuarão da mesma fórma com o irrisorio "gerente responsavel" do art. 56. Continuarão da mesma fórma os indecorosos anuncios: Precisa-se de um farmaceutico para dar nome a uma farmacia. Paga-se 80\$000. (D.V. ${ }^{47}, 1917$, p. 147).

Para leitura sobre o sanitarismo rural, consultar: Lima, N. T.; Hochman, G. Pouca Saúde e Muita Saúva: sanitarismo, interpretações do país e ciências sociais. Ciência e Saúde Coletiva, vol. 5, n. 2 p. 493-533, 2000.

${ }^{47} \mathrm{O}$ nome deste farmacêutico também não foi encontrado nos arquivos buscados. 
Reclamaram ainda que o farmacêutico foi o único profissional 'lembrado' pela legislação, excluindo outras pessoas que comercializavam medicamentos em nestes estabelecimentos de comércio de medicamentos. Independente dos fatores positivos ou negativos, essa participação de farmacêuticos nas novas preocupações em saúde em São Paulo traria mudanças para as práticas de terapia popular. As leis formuladas para pessoas envolvidas com o comércio de medicamentos, bem como a criação de novos medicamentos, funcionariam como outras possibilidades de cura, além dos métodos populares vigentes na época.

No meio das preocupações da classe farmacêutica com as práticas populares, o farmacêutico Cândido Fontoura também mostrou inquietação quando estas práticas de cura alternativas eram executadas pelos próprios farmacêuticos. Ao discutir sobre as funções de uma farmácia, as formas de assistência ao doente e o uso de medicamentos, considerou que o profissional responsável precisava possuir conhecimento técnico em farmácia, em decorrência dos danos que um mau profissional poderia ocasionar: “... a vida dos enfermos e a reputação do medico dependem da pharmacia. Um pharmaceutico ignorante e pouco escrupuloso pode ser a causa do sacrificio de preciosas vidas." (Fontoura, 1922, p. 169). Aqui neste ponto reforça-se que aquelas mudanças na profissão de farmácia por meio da educação técnica para os estudantes farmacêuticos eram importantes para atender às preocupações dos farmacêuticos. Isso mudaria as formas de se buscar as práticas de cura populares, pois se as funções em farmácia estivessem mais 'protegidas' por profissionais mais qualificados, sejam farmacêuticos ou práticos em farmácia, a população teria menos acesso ao farmacêutico 'ignorante e pouco escrupuloso' apontado por Fontoura.

Esse lado do farmacêutico atuando como um terapeuta popular foi representado, por exemplo, por suas indicações terapêuticas de medicamentos populares e de suas 'consultas médicas'. Conforme relata o farmacêutico Alberto Franscisco Giffoni em uma 'Conferência Humorística' (1922) no livro do Primeiro Congresso Brasileiro de Pharmacia:

A nossa pharmacia tem uma analoga apparencia com uma especie de lagarto da costa oriental africana, o qual muda de cores varias vezes no anno. É o feio, celebre e conhecidissimo cameleão. Ha occasiões em que a pharmacia toma a fôrma de armazem de seccos e molhados, vendendo um litro de alcool...de L. 
Queiroz; uma garrafa de vinho...Biogenico; ou uma vela...antiseptica; ou a manteiga...de cacau...

Outra vez, arvora-se em riquissima casa de joias e expõe em suas vitrines, perolas...de Silva Araujo. Outra hora, passa a ser carvoaria e vende Carvão...de Fontoura. Outro momento, mostra-se como boa casa de sorvetes, preparando chá...de sabugueiro. Parece tambem um bem montado bar e prepara saborosas limonadas...de citrato de magnesia...Por algum tempo quer se approximar da confeitaria, fabricando pastilhas de chocolate...com santonina...sortidos confeitos...laxativos. Sonha ser padaria e põe á venda pães...de opio ou biscouto vermifugo. Julga ser casa de instrumentos musicaes e vende Viola...Odorata. Quando quer ser um bem cultivado jardim, offerece flores...peitoraes...(p. 66).

Assim, farmacêuticos dialogavam com os meios alternativos de cura dentro de sua própria classe profissional. Em paralelo, eles tentavam se estabelecer como profissionais em farmácia na saúde pública de São Paulo esforçando-se para o seu reconhecimento profissional. Tal reconhecimento dependia também das relações dos farmacêuticos com outros profissionais da área de saúde, como por exemplo, com o médico. Fontoura (1922) mostra um pouco essa relação quando menciona que “...a vida dos enfermos e a reputação do medico dependem da pharmacia.” (p. 169). Fontoura mantinha estreitas relações com algumas personalidades médicas importantes no período republicano, que foram percebidas quando da fundação do Instituto Medicamenta, em sociedade com “...o Dr. A. Carini e apoio commercial do Sr. J. Ribeiro Branco e F. Nicolau Baruel...” (Sciencia Medica, 1927, p. 546). Carini foi um médico italiano importante na Primeira República, que aceitou o cargo de direção do Instituto Pasteur em 1906 (Ribeiro, 1997). Fontoura recebeu também o apoio de outros médicos de destaque, e isso foi conseguido devido ao sucesso de seu 'Biotônico':

O “Biotonico" não desmentiu as esperanças nelle depositadas por Candido Fontoura; amparado por vultos notaveis da classe medica paulista, como Pereira Barreto, Arnaldo Vieira de Carvalho e Côrte Real, para apenas citar os nomes dos fallecidos, tornou-se logo um tonico popular, cujo consumo cada vez maior justifica o conceito com que foi recebido por todos. (Sciencia Medica, 1927, p. 546).

Dentro destes embates e interesses profissionais, a regulamentação para o exercício da farmácia foi estabelecida já no início da década de 1890, com o decreto 
paulista n. 87, de 29 de julho de 1892. Tal decreto regulamentou a lei n. 43 de 1892, parte da nova legislação sanitária do estado, e atribuiu algumas regras para o exercício da farmácia, permitindo, por exemplo, as atividades de curar sob determinadas restrições não somente para a área farmacêutica, como também para a médica. Este exercício das atividades de farmácia só poderiam ocorrer sob a expedição de um diploma em farmácia. Conforme capítulo XII, artigo 25 da lei n. 43 de 1892:

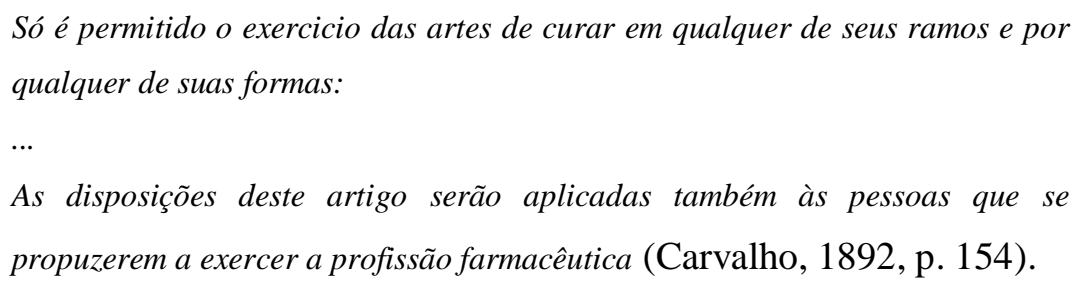

No artigo 26 da lei citada, enfatiza-se que os farmacêuticos deveriam se matricular na Diretoria de Higiene através da apresentação de seus títulos ou licenças para serem registrados. Ademais,

\footnotetext{
O registro se fará em livro especial e consistirá na transcrição do título ou licença com as respectivas apostilas. Feito o registro, o Diretor de Higiene lançará no verso do título ou licença o - VISTO -, indicará a folha do livro em que a transcrição tiver sido feita, datará e assinará.” (Carvalho, 1892, p. 154).
}

No caso dos profissionais não seguirem as regulamentações da diretoria de higiene, seriam multados conforme determinações impostas pelo serviço sanitário do estado:

Quem exercer a profissão medica ou pharmaceutica, sem titulo legal registrado na directoria do serviço sanitario, será multado em cem mil réis e nas mesmas quantias nas reincidencias, além das penas comminadas no Codigo Criminal.

(Gurgel, 1893, p. 174).

Esta regulamentação da profissão criava alguns obstáculos para aqueles indivíduos que exerciam as artes de curar sem terem cursado farmácia, e caso fossem autuados pela fiscalização, responderiam às suas práticas. Isso contribuía para mudar a situação das pessoas que praticavam 'ilegalmente' as artes populares. 
Após 1892, o farmacêutico ganhava destaque na saúde pública paulista. ${ }^{48}$ Por exemplo, a fundação da União Farmacêutica de São Paulo aconteceu em 7 de setembro de 1913. Segundo Santos (1993), a fundação desta associação visava dar reforço à cientificidade e ao profissionalismo do farmacêutico. A normatização das principais atividades de farmacêuticos ocorreu devido às novas conformações no campo da saúde pública: a organização do serviço sanitário, o nascer de um novo espaço para diversos profissionais de saúde, somados às transformações nas cidades (Silva, 2003; Costa, 1985).

Porém, mesmo com estas primeiras mudanças nas bases da profissão farmacêutica, os profissionais ainda reclamavam do exercício das práticas populares e dos charlatães exercendo a farmácia:

Apezar de existir aqui um regulamento que exige provas de habilitação para o exercicio legal das profissões medica e pharmaceutica, o exercicio illegal é, entretanto, francamente tolerado com flagrante violação da lei, e o resultado dessa tolerancia é que o exercicio illegal da medicina e da pharmacia, e o simultaneo dessas duas profissões, é praticado ás escancaras até mesmo na séde do governo do estado de S.Paulo.

$\cdots$

Si a liberdade de profissão, em qualquer dos ramos da arte de curar, fosse exercida por pessoas competentes, diplomadas ou não, ella seria logica, teria razão de ser; mas isso não se dá, - nós todos o sabemos - e o governo egualmente sabe.

Um aventureiro qualquer, um charlatão, imtitula-se medico, faz annuncios pomposos dizendo curar molestias incuraveis; fabrica numerosos agradecimentos á sua pessoa por curas milagrosas, e vê dentro em pouco o seu consultorio procurado pelos pobres enfermos avidos de saude.

Outro especulador abre uma pharmacia e, servindo-se dos mesmos meios empregados, consegue em breve enorme clientela, com grave prejuio para a saude publica. (Revista Pharmaceutica, 1895, p. 23-24).

Um fator que contribuiu para a permanência das práticas de cura populares foi o desenvolvimento inicial da indústria de medicamentos que, conforme já indicamos,

\footnotetext{
48 Em âmbito nacional, houve a regulamentação da Sociedade Farmacêutica Brasileira em 1851 por Ezequiel Correia dos Santos. Consultar: Araújo, C. da S. Figuras e Factos na História da Farmácia no Brasil Português. Trabalho apresentado ao $3^{\circ}$. Congresso Luso-Espanhol de Farmácia, em Santiago de Compostela, de 22 a 29 de Agosto. Lisboa: Editorial Império, p. 71, 1954.
} 
entrava aos poucos na vida da população republicana. Exemplar disso é a disponibilidade de fórmulas novas, o que possibilitava o fácil acesso pela população. A grande quantidade de anúncios de medicamentos em jornais de circulação da época mostrava essa facilidade. Dois exemplos, dentre vários outros, mostraram a forma de se transmitir a informação ao leitor da época. O primeiro, na cidade de São Paulo: o Diario Popular ${ }^{49}$ (1892) destacou um medicamento produzido por uma indústria de medicamentos, as 'capsulas Riedel', em forma de anúncio publicitário em várias de suas edições, com o aval da inspetoria de higiene. O segundo, na cidade de Ribeirão Preto, interior de São Paulo: A Cidade $^{50}$ (1905) publicou um anúncio de um estabelecimento de comércio de medicamentos denominado Pharmacia Italiana, destacando as facilidades em se comprar um medicamento desta farmácia. Mesmo dentro da própria classe farmacêutica ocorria a publicação de propagandas de medicamentos, com o intuito de disseminá-los para os farmacêuticos. Especialmente a seção "Chronica" da Revista Pharmaceutica distribuía informações sobre novos medicamentos e alguns já testados como eficazes no mercado farmacêutico ${ }^{51}$. Ressalta-se aqui, entretanto, que estes anúncios atingiam somente a parte da população que era leitora de jornais.

Neste sentido, farmacêuticos começavam a se destacar profissionalmente nas questões relacionadas à produção, ao comércio e ao uso de medicamentos. Seus discursos voltaram-se, por exemplo, para os resultados negativos do comércio de matérias-primas para produzir os medicamentos para a população. A Cooperativa Pharmaceutica (1897) alegava que esse comércio era alto, e que os fornecedores eram pessoas 'ignorantes' - era preciso garantir a pureza dessas drogas para garantir a qualidade dos preparados farmacêuticos (p. 117-119). Um farmacêutico destacou ainda em uma das edições da Revista Pharmaceutica (1895) que o Centro Pharmaceutico Brazileiro solicitou ao Congresso que aumentasse os impostos ${ }^{52}$ sobre produtos farmacêuticos de origem estrangeira, favorecendo a indústria nacional,

\footnotetext{
${ }^{49}$ Ver figura da propaganda destas cápsulas na seção 'Anexos': pg. 161, Anexo IV. Reproduzido do acervo do Arquivo Público do Estado de São Paulo. Pasta Diário Popular julho-novembro 1892. Código VAR-084.

${ }^{50}$ Ver figura da propaganda de um estabelecimento de comércio de medicamentos na seção 'Anexos': pg. 162, Anexo V. Reproduzido do acervo do Arquivo Público do Estado de São Paulo. Pasta 29 Interior de São Paulo. Código VAR064.

${ }^{51}$ Ver figura da propaganda de um estabelecimento de comércio de medicamentos contida na Revista Pharmaceutica de 1897 na seção 'Anexos': pg. 163, Anexo VI.

${ }^{52}$ Discutimos mais adiante os impostos sobre os produtos farmacêuticos.
} 
“...hoje adiantadissima, será larga e justamente favorecida." (p. 87). Isso contribuiria para diminuir as fraudes no comércio de drogas. Em 1904, nove anos depois, seria fundado o Centro Pharmaceutico Paulista, que agiria de forma a coibir o exercício daquelas pessoas 'ignorantes' (Revista Pharmaceutica, 1905, p. 18). A Revista Pharmaceutica de 1905 creditou um benefício da fundação do Centro Pharmaceutico Paulista para proteger a população até mesmo contra eventuais práticas 'ilícitas' da própria classe farmacêutica, alegando que

São poucos os pharmaceuticos que se preoccupam com a verificação da identidade e da pureza das drogas que adquirem para o aviamento das receitas medicas. Assim como as recebem dos seus fornecedores, assim as empregam, sem se preoccuparem com o que possa acontecer. (p. 18).

Havia uma punição monetária para aqueles em que a fiscalização autuasse fraudando a produção de medicamentos: “...os que venderem remedios falsificados $e$ os que na composição das preparações officinaes substituirem umas drogas por outras, serão multados em cem mil réis e no dobro nas reincidencias." (Gurgel, 1893, p. 175).

Esta punição foi destacada por farmacêuticos na edição de 1899 da Revista Pharmaceutica. As autoridades fiscalizadoras multaram alguns indivíduos envolvidos nas práticas de comercializar medicamentos e de dar diagnósticos. Seguem os números referentes às:

\footnotetext{
...multas por: exercicio ilegal da medicina (2); abandono de farmacia (2); exercicio ilegal da obstetricia (1) e da farmacia (1); vender preparados medicinais (1); $e$ aviar receita de curandeiro (1). (p. 167).
}

Embora tenham sido muito poucas multas, sem explicação do modo como foi conduzida a fiscalização, os farmacêuticos publicaram-nas com um tom de 'vitória', como se mostrassem o 'primeiro passo' dado no combate às ações de indivíduos que exerciam a farmácia e a medicina sem diploma frente às instâncias que regulavam as atividades em medicina e em farmácia. A lei n. 240 de 1893 estabelecia uma punição não somente para os terapeutas populares, como também para os próprios farmacêuticos: 
Os pharmaceuticos e quaesquer pessoas extranhas á profissão pharmaceutica ou de droguista ${ }^{53}$, que venderem ou prepararem remedios secretos serão multados em cem mil réis e no dobro nas reincidencias. (Gurgel, 1893, p. 175).

Estas lutas, entretanto, não eram apenas voltadas para proteger a população paulista dos charlatães e de suas curas populares. Pareciam muito mais um 'motivo' encontrado pela classe farmacêutica para encobrir seus interesses privados, uma vez que desejavam ascender na área de saúde com reconhecimento profissional. Por exemplo, os farmacêuticos incomodavam-se pelo fato de serem considerados 'negociantes' de medicamentos. Estes profissionais sabiam que vendiam medicamentos a preços elevados para poder lucrar com tal comércio, e os altos preços impediam, muitas vezes, a população de baixa renda pagar pelos medicamentos. Costa (1895) argumentou que o maior objetivo do farmacêutico era o de vender medicamentos prescritos pelos médicos, mas que muitas vezes os doentes não pagavam pela compra por sua precária condição financeira. A preocupação dos farmacêuticos exacerbava-se à medida que sabiam da punição legal para suas profissões, por meio de processo judicial e “...até ter a sua casa fechada.” (Costa, 1895, p. 50). A lei n. 240, de 4 de setembro de 1893 estabelecia a proibição da exploração da indústria farmacêutica por meio de associação entre farmacêuticos e médicos (Gurgel, 1893, p. 169). Esta exploração deixava implícito que nenhum dos dois profissionais poderia tirar vantagem com o comércio de medicamentos quando o assunto fosse saúde. Porém, a lei não continha nenhuma ressalva quanto ao que fazer se uma pessoa doente não pudesse pagar pelo seu medicamento.

A prática de profissionais farmacêuticos e médicos, entretanto, não seguia sempre a legislação em vigor no período. Nos Annaes do Primeiro Congresso Medico Paulista (1916), foi publicado um artigo ressaltando a importância da associação da indústria com a medicina, com o argumento de que tal conexão contribuiria para facilitar o trabalho entre os profissionais de saúde. Ao final do congresso, os

\footnotetext{
${ }^{53}$ Droguistas são poucas vezes citados na legislação que organizou o serviço sanitário de 1892 . Não se encontrou nenhuma atuação de destaque na saúde pública como foi observado na Inglaterra. As funções atribuídas a eles eram de 'selecionadores' e vendedores das matérias-primas para o fabrico de remédios por farmacêuticos e homens sem diploma em farmácia. Da mesma forma, praticamente não se encontrou, nos discursos da classe farmacêutica, a menção ao papel dos droguistas na Primeira República no estado de São Paulo.
} 
organizadores criaram uma exposição de produtos das mais diversas origens, e a denominaram de "Exposição de Hygiene", incluindo produtos alimentícios químicos, biológicos, especialidades farmacêuticas. Conforme relato em circular da época,

\begin{abstract}
A Commissão organizadora do Primeiro Congresso Medico Paulista, no intuito de estender quanto possível a sua acção em benefício da saude publica e interessada em concorrer com o seu esforço para a solução racional desse problema resolveu a abertura duma Exposição que virá offerecer ás industrias que se relacionam com a Hygiene e ao commercio em geral uma opportunidade de tornar conhecidos os seus productos.

Essa Exposição, promovida no interesse da communhão social e a bem do desenvolvimento industrial, comportará productos chimicos, pharmaceuticos, alimentícios e accessorios que directamente se prendem á hygiene e á saude publica. (p. 372). ${ }^{54}$
\end{abstract}

Houve, inclusive, a distribuição de medalhas e diplomas aos vencedores dos melhores produtos, com destaque para as indústrias alimentícias, farmacêuticas e químicas (idem, p. 371-373). O próprio farmacêutico Cândido Foutoura entendia que as relações entre médicos, indústria farmacêutica e farmacêuticos era necessária para o desenvolvimento do comércio de medicamentos (Sciencia Medica, 1927). Esse foi, de fato, um período importante para o crescimento da indústria nacional, pois os países que forneciam medicamentos para o Brasil estavam envolvidos na Primeira Guerra Mundial, e conforme já destacamos, Campos (1966) apontou que isso permitiu o aumento da produção nacional.

Em oposição, outro farmacêutico relatou as novas condições às quais sua classe estava exposta, reclamando da influência negativa da indústria na saúde da população. Numa discussão sobre a nova situação dos extratos fluidos, acentuou que estes compostos passaram a ser produzidos pela indústria e que isso aumentou muito a concorrência, caindo a qualidade dos produtos e até mesmo elevando as possibilidades de falsificação. Não havia como distinguir um produto bom de um falsificado, e que os farmacêuticos tinham que lidar com esta nova situação. Com estes acontecimentos, ganhavam e perdiam espaço na área da saúde:

\footnotetext{
${ }^{54}$ Ver figura de propaganda de medicamento contida na Revista de Medicina de 1918 na seção 'Anexos": pg. 164, Anexo VII.
} 
Fez vêr que o pharmaceutico de hoje já não goza daquelle prestigio de que o cercava o povo que presenciava o interesse e cuidado com que elle por suas proprias mãos ia colher, nas cercanias de suas cidades, as plantas medicinaes de que necessitava. Diz que entre os pharmaceuticos de hoje já não pode haver aquella fraternidade que se originava das permutas constantes de drogas e plantas preparadas ou collecionadas nas diferentes regiões de um mesmo paiz ou de paizes diversos. (Dias, 1897, p. 72-73).

Essa falta de prestígio dos farmacêuticos era alimentada por aqueles indivíduos que praticavam as artes populares, onde muitos deles trabalhavam com invenções farmacêuticas. Isto também foi observado na nova legislação do estado de São Paulo, que permitia a execução da prática de farmácia por pessoas comuns, desde que seguissem as regulamentações determinadas pela Diretoria de Higiene:

Artigo 45 - $O$ inventor de qualquer remedio que quiser expo-lo a venda devera para esse fim requerer licenca a Diretoria de Higiene, apresentando um relatorio no qual declare a composição do remedio e a molestia em que a sua administração será proveitosa. (Carvalho, 1892, p. 157).

Os próprios farmacêuticos discutiram essa questão das invenções medicamentosas permitidas legalmente. Destacou-se que na lei n. 240, de 4 de setembro de 1893, havia três artigos importantes que propiciariam um rigor maior nas práticas de pessoas não-qualificadas a atuarem na venda de medicamentos: o primeiro, artigo 97, cuja venda de medicamentos só poderia acontecer em farmácias e drogarias, pois estas fórmulas eram vendidas até mesmo em armazéns de ferragens; os demais, artigos 53 e 61, exigiam a presença do farmacêutico em farmácia, pois um italiano, segundo relato do editor da revista, abriu uma farmácia, mas não possuía farmacêutico (Sociedade Pharmaceutica Paulista, 1895, p. 41-42).

Essa questão da abertura de estabelecimentos de comércio de medicamentos foi um fato importante que também influenciou no controle das práticas populares de cura, pois se aumentou a fiscalização em três itens importantes: nos próprios locais de comércio de medicamentos, na manipulação dos compostos químicos utilizados nas fórmulas e nas próprias pessoas envolvidas neste comércio. No primeiro item, a punição caía diretamente sobre o profissional farmacêutico em caso do não cumprimento das exigências legais: 
O pharmaceutico que se oppuzer ao exame de suas pharmacias, quando for isto exigido pela auctoridade competente, incorrerá na multa de duzentos mil réis, e será obrigado a fechar o estabelecimento, não podendo reabril-o sem licença do director do serviço sanitario, que procederá então de conformidade com o disposto no art. 63 e relativo ás pharmacias novas. (Gurgel, 1893, p. 175).

Quanto ao segundo item, os farmacêuticos que manipulassem medicamentos em desacordo com as especificações contidas na lei n. 240 de 1893 também seriam prejudicados:

Os pharmaceuticos que prepararem remedios de modo diferente do Codex adoptado, os que venderem remedios falsificados e os que na composição de preparações officionaes substituirem umas drogas por outras, serão multados em cem mil réis e no dobro nas reincidencias. (Gurgel, 1893, p. 175).

Por fim, o terceiro item também punia farmacêuticos, mas quanto aos tipos de práticas médicas exercidas por eles:

O pharmaceutico que em sua pharmacia der consultas, fizer curativos ou applicar apparelhos a não se em casos de desastres, accidentes de ruas ou outros similhantes será multado em cem mil réis e no dobro nas reincidencias, além das penas do Codigo Criminal applicaveis contra o exercicio illegal da medicina. (Gurgel, 1893, p. 174).

Como se percebe, o controle caía diretamente em cima das funções dos farmacêuticos. Interpretamos a determinação dessas regulamentações em face das tentativas governamentais em se controlar as ações de outros indivíduos que atuavam em paralelo às funções de farmacêuticos, que não possuíam diploma em farmácia, que mexiam com as artes de fazer fórmulas sem a técnica farmacêutica - eram barreiras para frear as ações dos 'charlatães' dos medicamentos. Mesmo os farmacêuticos mostravam seu interesse em controlar estas atitudes 'ilegais' de pessoas que trabalhavam nos estabelecimentos de comércio de medicamentos, e isso foi uma maneira de ganharem espaço, aos poucos, na saúde pública paulista. De 
acordo com o relato do professor Edmond Dupuy (1902), ao destacar que a profissão farmacêutica não é:

...como querem seus detractores, um commercio de drogas e de medicamentos a retalho como qualquer outro; que não deve ser aproveitada, como querem os charlatães, para fazer fortuna especulando a credulidade e o soffrimento publico; porém que, do mesmo modo que a medicina, ella tem por base a confiança cega dos doentes, e que, como ella, tem direito a occupar um lugar elevado na hierarchia social, pela missão humanitaria que preenche, pelos serviços que tem prestado ás sciencias, ás artes e á industria. (p. 25).

Para se ter uma idéia em números dessas fiscalizações, durante o primeiro trimestre de 1917, 23 farmácias da capital e 8 no interior foram multadas por irregularidades; no quarto trimestre, apenas 4 na capital, em oposição ao aumento significativo de multas no interior: 20 multas foram expedidas (Boletim Trimestral de Estatistica Demographo-Sanitaria de São Paulo, p. 264-266, 1917).

Segundo Edler (2006), estes locais de venda de medicamentos foram se transformando dos locais artesanais de produção e venda do início do século XIX para locais com mais infra-estrutura técnica, culminando em espaços dotados de maquinário e pessoal mais qualificados para produzir medicamentos com características industriais. As farmácias herdaram aparatos instrumentais das antigas boticas, e ao longo do século XX, transformaram-se em indústrias. Um exemplo é a Casa Baruel, fundada em 1892. Um destaque especial publicado na Revista Medica de S. Paulo de 1899 descreve funções, qualidades e outras características deste estabelecimento, que segundo o relatório, é “...uma das mais importantes drogarias da América, sem duvida a maior do Brazil e uma das melhores, senão a melhor também, da América do Sul." (p. 210). O autor afirma que a drogaria é um estabelecimento de “...aspecto attrahente..." (p. 211), com o intuito de chamar a atenção dos clientes e doentes que por ali passavam. Edler (2006) aponta que esta casa, localizada na região central de São Paulo, vendia produtos de toalete importados da Europa. No final do século XIX, ampliou-se e transformou-se em laboratório farmacêutico, com a função de elaborar produtos médicos. 
Nestes estabelecimentos, era cada vez mais evidente o comércio de produtos nacionais em detrimento dos produtos estrangeiros. Segundo o farmacêutico A. A. S. ${ }^{55}$ (1898), os medicamentos obtidos no exterior não possuíam, em sua maioria,

...o principio medicamentoso conforme diz o rotulo, são misturas hibridas sem nome que sahem da Alfandega para entrarem no estomago depauperado do pobre consummidor produzindo-lhe muita vez a morte; é simplesmente uma calamidade, digno do maior cuidado, que além do preço exageradissimo, conduzimos ao nosso lar a morte engarrafada com o nome de medicamento. (p. 104-105).

Com efeito, o relatório do Laboratorio Pharmaceutico do Estado, publicado pelo seu então diretor, Cristovam Buarque de Hollanda, divulgou essa preocupação com fraudes relacionadas à distribuição destes medicamentos no estado, bem como o posterior uso deles (1897, p. 13). Por conta disso, este laboratório passou por uma nova emenda em 1907, complementando a lei n. 432 de 3 de agosto de 1896: o decreto n. 1439, de 15 de fevereiro de 1907, determinou que esta instituição era, a partir daquele momento, responsável por

...fornecer drogas, productos chimicos e pharmaceuticos, desinfectantes
vasilhame, utensilios, etc., ás secções annexas á Directoria do Serviço
Sanitario, ao Hospicio de Alienados de Juquery, ás Escholas Polytechnica e
Normal, bem como aos outros estabelecimentos publicos da Capital e do
interior do Estado, a juizo do governo... (Godoy, 1907, p. 35).

Tal ação governamental sugere a preocupação com estas fraudes e outras questões relacionadas ao comércio de medicamentos. Segundo Queiroz (1922), a defesa da classe farmacêutica pela regulamentação da 'Cooperativa Farmacêutica' estava respaldada na proteção da classe e da população contra os abusos nesse comércio de medicamentos. Afirmou que

A difficuldade em identificar as drogas que compra e com as quaes prepara os medicamentos que fornece ao publico é, talvez, o que mais preoccupa o pharmaceutico zeloso, por causa dos accidentes que podem ocorrer.

\footnotetext{
${ }^{55} \mathrm{Da}$ mesma forma que as notas anteriores, não foi identificado o nome por extenso de A.A.S.
} 
Ora, essa identificação é quasi impossivel, porque, além da pericia necessaria para analysar os mais variados productos, é tambem indispensavel o sacrificio de tempo e dinheiro.

A cooperativa, adquirindo por atacado essas drogas directamente do fabricante, disporá necessariamente de um laboratorio apropriado, com pessoal competente para fazer essas analyses, garantindo aos seus associados a pureza e identidade de todos os artigos que fornecer. (p. 161).

A adulteração de medicamentos também foi outro problema na saúde pública. Farmacêuticos, por exemplo, discutiram diversas vezes as maneiras de se combater esta prática, que era executada por inúmeras pessoas. O Boletim de Therapeutica, Pharmacia e Chimica de Santos, estado de São Paulo, dedicou um espaço em sua edição de junho de 1923 para relatar sobre as fraudes cometidas com produtos farmacêuticos, tanto em relação à falsificação de drogas como em relação a produtos impuros:

O falsificador trabalha, esforça-se, experimenta, para augmentar a quantidade e o valor do produccto e o assemelhar ao legitimo. A Sociedade, por sua vez, trabalha, esforça-se, experimenta, em sua legitima defesa, para descobrir a fraude, e quer num, ou noutro caso, progride a industria pelo aperfeiçoamento dos processos de fabricação, e a sciencia applicada, pelo apparecimento de novos meios para distinguir o falso do verdadeiro, o puro do impuro. (p. 71).

Desta forma, um controle maior na produção e no comércio de medicamentos no Brasil surgiu em decorrência de tais fraudes: questões de natureza política e econômica esbarravam-se às necessidades sociais de controle no uso de medicamentos. De fato, a legislação sanitária de 1892 em São Paulo destacou a criação de leis voltadas para a aprovação de novos medicamentos, que eram chamados de "especialidades pharmaceuticas". A definição das especialidades farmacêuticas contida no decreto n. 3267 de 10 de abril de 1899 era a de

Todo o remedio officinal, simples ou complexo, acompanhado ou nao do nome do fabricante, procedente do estrangeiro ou produzido no paiz, preparado e indicado em dóses medicinaes, e annunciado, nos respectivos rotulos, prospectos ou titulos, 
como capaz de curar, por applicacao interna ou emprego externo, certa molestia, grupo de molestias ou estados morbidos diversos. ${ }^{56}$

No Brasil, a fiscalização em cima do comércio de medicamentos iniciou-se com a taxação dos mesmos pela lei n. 559, de 31 de dezembro de 1898. Segundo Toledo (1898), a intenção desta lei era de orçar a receita para o ano seguinte, e por meio do artigo 1, n. 51:

Especialidades pharmaceuticas nacionaes e estrangeiras, por vidro, caixinha ou qualquer outro involucro, 100 reis ate 5\$, e de preco superior, 200 reis. (p. 50).

Esta lei foi revogada pelo decreto n. 3267 de 10 de abril de 1899. Este decreto foi denominado "Regulação da importação de consumo sobre especialidades pharmaceuticas", e estabeleceu novas diretrizes para o comércio de medicamentos. A determinação desta lei deixa implícito se realmente desejava-se orçar a receita de medicamentos para o ano seguinte ou se a intenção era outra, como a de arrecadar mais dinheiro para o governo por meio desses impostos sobre os medicamentos, ou ainda de desincentivar o comércio destes produtos. Estas incertezas deixam dúvidas quanto aos motivos que levaram as autoridades governamentais a aumentar o controle sobre os produtos farmacêuticos e sobre os próprios profissionais farmacêuticos. Era para impedir as atividades de manipulação de fórmulas caseiras? Era para frear as ações dos terapeutas populares que se passavam por farmacêuticos? Ou era simplesmente para regulamentar a profissão de farmácia e todos os assuntos à ela vinculados? Um ponto bastante interessante foi a determinação da incidência do imposto para diversos grupos de comerciantes, até mesmo para 'mercadores ambulantes', que não possuíam credenciais em farmácia, mas vendiam fórmulas artesanais:

Art. 2 O imposto compõe-se do registro das fabricas, depositos, casas de negocio e mercadores ambulantes e das taxas constantes da tabella annexa. ${ }^{57}$

\footnotetext{
${ }^{56}$ Disponível em: http://www2.camara.gov.br/internet/legislacao/legin.html/textos/visualizarTexto.html?ideNorma=5143 $19 \&$ seqTexto=1\&PalavrasDestaque $=$ ). Acesso em 01/12/2008.

${ }^{57}$ Disponível em: http://www2.camara.gov.br/internet/legislacao/legin.html/textos/visualizarTexto.html?ideNorma=5143 $19 \&$ seqTexto=1\&PalavrasDestaque $=$ ). Acesso em 01/12/2008.
} 
Ao mesmo tempo em que havia punições para homens que exercessem os ofícios em farmácia sem um diploma na área, dava-se uma 'oportunidade' para eles, desde que pagassem determinadas taxas pelo seu comércio. Segundo o farmacêutico S. ${ }^{58}$ (1899), a taxação de medicamentos estava ligada a interesses governamentais maiores, "Para dominar a crise financeira, que é como que o eixo em torno do qual vai girando o nosso descalabro geral, a unica ideia que acudiu ao espirito dos encarregados da gestão publica foi cortar despezas e lançar impostos.” (p. 160). A cobrança de impostos dos medicamentos foi creditada ao ministro da Fazenda, um médico homeopata de importância na saúde pública. O farmacêutico argumentou que o ministro

\begin{abstract}
...suggeriu como medida salvadora das finanças deterioradas um imposto de consumo sobre as especialidades pharmaceuticas nacionaes e estrangeiras, imposto que o congresso voltou reduzido á metade e que ainda assim é oneroso e iniquo. E o publico, que de tres annos a esta parte, vive a queixar-se da excessiva carestia dos medicamentos, carestia oriunda da baixa do cambio e dos pesados tributos incluidos na ultima tarifa aduaneira, o publico que satisfaça as novas exigencias e não bufe, ou então que recorra a medicinas mais baratas, que procure os charlatães, os escudeiros, os homoeopathas. Eis o dilemma, com respeito ao publico; quanto aos commerciantes de drogas e preparados que soffram pacatamente os vexames da nova imposição, que preguem os respectivos sellos em todos os vidros seja quaes forem as dimensões destes, ainda mesmo quando o sello fôr maior que o vidro...(p.
\end{abstract} 160-161).

Neste paradoxo de ações é que a terapia popular foi ganhando um contorno diferente no estado de São Paulo, e as regulamentações foram uma mostra de que as práticas de cura populares seriam influenciadas com a legitimação do profissional farmacêutico o controle sobre as atividades dos 'charlatães' das fórmulas dava passos lentos, ora permitindo as práticas populares, ora proibindo as mesmas.

Assim, mesmo com a taxação dos produtos farmacêuticos, a produção, o uso e a venda de especialidades farmacêuticas durante a Primeira República continuou a ser pauta na agenda das autoridades governamentais e farmacêuticas. Produtos nacionais e estrangeiros precisavam passar por outras formas de controle, com atenção à

\footnotetext{
${ }^{58}$ Também não foi localizado o nome por extenso do farmacêutico $\mathrm{S}$.
} 
composição, rotulagem, bulas, análises químicas. Era preciso também fiscalizar as ações dos responsáveis profissionais que possuíam contato direto com o consumidor do medicamento em questão. Conforme relata o farmacêutico Virgilio Lucas no livro do Primeiro Congresso Brasileiro de Pharmacia, realizado de 12 a 22 de outubro de 1922:

É necessario que se adoptem providencias efficazes no sentido de não ser permittida a exploração da nobre sciencia de curar por esses processos, em que só a ganacia e ambição imperam. Seria de grande importancia uma possivel educação do nosso povo, com o objectivo de afastal-o do uso perigoso das drogas mal applicadas, mostrando qual o verdadeiro caminho a seguir, nos tempos modernos, na conquista da saude e do bem estar. (p. 165-166).

Farmacêuticos desejavam abolir a venda de medicamentos em quaisquer casas de ferragens por quaisquer indivíduos:

\begin{abstract}
Não vejo, por exemplo, razão plausivel que justifique o abuso das lojas de ferragens venderem drogas e medicamentos e só a inaudita tolerancia deste paiz, para não empregar outra phrase, explica tão insolita anomalia. Si extranho o facto relativamente aos lojistas, não devo omitti-lo com relação aos droguistas que não podem vender drogas a pesos medicinaes e a retalho e entretanto o fazem. A lei prohibe o facto, mas infelizmente não se pune a infracção de maneira que surta effeito de modo efficaz; eu penso que se devem estabelecer penas mais ou menos severas, conforme a frequencia das reincidencias... (Costa, 1895, p.
\end{abstract} 48).

Diante de todas estas preocupações e interesses dos farmacêuticos, havia ademais a questão das tarifas aduaneiras sobre os produtos químicos puros e impuros, que também davam margem para a ocorrência de fraudes. De acordo com relatório do Boletim da Sociedade de Pharmacia e Chimica de São Paulo, fornecedores de matérias-primas misturavam um percentual mínimo de outro componente químico ao componente principal do medicamento, por exemplo, “...o nitrato de potassio contém 1 x 10000 de chloretos...", "A soda Solway contém 99\% de carbonato de sodio puro...". Isto influenciaria o mínimo na alteração da fórmula, quimicamente seria quase imperceptível, mas gerava confusão no momento desses produtos passarem pela alfândega, o que facilitava a cobrança de multas e a execução de fraudes. Os 
responsáveis pediam, assim, uma lista oficial dos compostos para uso nas alfândegas, bem como a taxação dos mesmos (Penteado \& Queiroz, 1926, p. 10).

A dificuldade em melhorar o quadro de fraudes, falsificações e charlatanices estava ligada ao fato do comércio de medicamentos ser um negócio lucrativo, deixando a saúde da população em segundo plano. Embora as fiscalizações tenham continuado ao longo do período republicano, não havia como controlar todos os casos e todas as pessoas envolvidas. Os próprios farmacêuticos possuíam seus interesses pessoais, o que dificultava ainda mais o cuidado da saúde. Duas questões foram importantes para justificar essa dificuldade: a primeira, o fato do crescimento industrial se elevar a cada ano, o que trazia mais descobertas de produtos químicos, somados à facilidade de acesso aos mesmos. Apesar do inicial desenvolvimento industrial aqui, Cytrynowicz (2007) aponta que havia 49 estabelecimentos de especialidades farmacêuticas antes de 1890 no Brasil; entre 1890 e 1909, 208; entre 1910 e 1913, 195 empresas. A autora enfatiza que as duas primeiras décadas do século $\mathrm{XX}$ foram as mais importantes em termos de desenvolvimento da indústria farmacêutica, geralmente associada à indústria química, especialmente no Rio de Janeiro e em São Paulo.

Em segundo lugar, a facilidade de se inventar fórmulas, não necessitando de um livro de referência, permitiam a manipulação por qualquer pessoa. Tal argumento é válido se considerarmos que foi somente em 1926 que surgia a farmacopéia brasileira, de autoria de Rodolfo Albino Dias da Silva (Edler, 2006; Santos, 1993). De acordo com o decreto n. 87 de 1892, as fórmulas manipuladas deveriam seguir a farmacopéia francesa. Farmacêuticos, por exemplo, reclamavam que era difícil seguir as fórmulas do Codex francês porque os medicamentos que nele existiam não correspodiam ao que o Brasil podia produzir, já que nossas matérias-primas eram, em sua grande maioria, retiradas da rica flora do país. Isso não apenas dificultava a produção de medicamentos aqui, como também restringia a manipulação das fórmulas. Conforme aponta o farmacêutico Queiroz (1906), a farmacopéia brasileira “...deverá conter não só os medicamentos de uso universal como tambem os de uso corrente no proprio paiz; ora, dada a extensão do nosso territorio e a riqueza de nossa flora medicinal, a descripção das plantas medicinaes brazileiras e seu estudo seriam trabalho bastante pesado para uma commissão de 3 ou 5 membros.” (p. 3).

A despeito dos interesses envolvidos entre farmacêuticos, indústria, autoridades governamentais e a população, as determinações impostas na legislação 
sanitária do estado de São Paulo acabaram, de certa forma, estimulando o controle do exercício da farmácia. Segundo o Boletim Mensal de Estatistica DemographoSanitaria de São Paulo e dos municípios de Santos, Campinas, Ribeirão Preto, São Carlos, Guaratinguetá e Botucatu, a inspetoria de fiscalização da medicina e da farmácia fez uma busca em relação ao comércio de tóxicos na capital e no interior: de um total de 1.085 fiscalizações, 746 foram em São Paulo e 339 no interior do estado (1927, p. 62). Não há menção, entretanto, do modo como foram conduzidas estas fiscalizações. É possível que o número mais elevado de fiscalizações na capital esteja relacionado ao inicial desenvolvimento das indústrias farmacêuticas, ou então, ao desenvolvimento dos estabelecimentos de comércio de medicamentos.

A fiscalização ocorreu também sobre produtos químicos para análises: no primeiro trimestre de 1917, ocorreram 21 apreensões destes produtos, tanto na capital como no interior (Boletim Trimestral de Estatistica Demographo-Sanitaria de São Paulo, 1917, p. 264-265). Já em 1927, ocorreu apenas 1 apreensão dos preparados para análises, no mês de novembro, e somente na capital (Boletim Mensal de Estatistica Demographo-Sanitaria de São Paulo, 1927, p. 62). Em dez anos, diminuiu-se o número de apreensões em quase 10 vezes: em 1917, das 21 apreensões em 3 meses, podemos fazer uma média de 7 apreensões por mês; em 1927, 1 apreensão em 1 mês. Não se sabe se foi o rigor das fiscalizações o fator contribuinte na diminuição do número de substâncias apreendidas; ou menos fiscalizações; ou outros interesses das autoridades responsáveis. Todas estas fiscalizações foram feitas a partir da Diretoria do Serviço Sanitário do Estado de São Paulo, com a atuação do setor de policiamento sanitário.

Tais fiscalizações foram importantes porque determinados medicamentos eram utilizados acima de suas doses tóxicas, causando algumas mortes por envenenamento. Por este motivo, alguns farmacêuticos publicaram uma lista de medicamentos, com suas doses tóxicas medicamentosas:

Tabela 2. Lista de medicamentos publicada por farmacêuticos em São Paulo (adaptado de Barros, 1915, p. 568-569)

\begin{tabular}{|l|c|c|}
\hline \multirow{2}{*}{$\begin{array}{l}\text { Nome dos medicamentos } \\
\text { (Uso interno) }\end{array}$} & \multicolumn{2}{|c|}{ Doses toxicas } \\
\cline { 2 - 3 } & Para adultos & Para crianças \\
\hline Absinthina................... & 0,40 & 0,20 \\
\hline Acido arsenioso.............. & 0,10 & 0,05 \\
\hline
\end{tabular}




\begin{tabular}{|l|c|c|}
\hline Acido sulfurico............. & 4,00 & 2,00 \\
\hline $\begin{array}{l}\text { Chloral } \\
\text { hydratado...................... }\end{array}$ & 8,00 & 4,00 \\
\hline Elixir paregorico.............. & 20,00 & 10,00 \\
\hline
\end{tabular}

Neste misto de desenvolvimento industrial e cuidado popular, os farmacêuticos paulistas acabavam atuando na área de saúde como profissionais charlatães, em paralelo ao desenvolvimento científico de suas profissões, conforme relatado anteriormente. Para contrapor este caráter popular dos farmacêuticos, havia prestígio para aquele lado do farmacêutico que trabalhava como responsável técnico 'diplomado', cujos trabalhos eram reconhecidos por profissionais médicos:

\footnotetext{
Attesto que tenho usado em minha clinica com muita vantagem em casos de influenza, bronchite e de asthma, do Xarope de Grindelia composto, do pharmaceutico Samuel de Macedo Soares.

Isto é verdade e o juro sob fé de meu gráo.

Dr. Alvaro Caminha Tavares da Silva.
}

Ilmo. Sr. Samuel de Macedo Soares - Com satisfação communico-vos que tenho usado em minha clinica, obtendo resultados animadores, o vosso Myostenio; excellente preparado, de segura efficacia nos casos de lymphatismo e perda de forças

S. Paulo

Dr. Xavier da Silveira (Soares, dez. 1908, p. 125).

Contribuiu para este prestígio 'científico' dos farmacêuticos frente à classe médica, o reconhecimento pelo governo federal da Escola Livre de Pharmacia em 1898, que permitiu à classe farmacêutica reforçar seus conhecimentos em química, botânica, zoologia, física, bacteriologia, terapêutica, higiene (Souza, 1904). Adicionalmente, os futuros farmacêuticos aprendiam matérias relacionadas à indústria, dentro de um laboratório de farmácia da própria escola:

E vem de molde citar o Laboratorio de Pharmacia, que ella possue, verdadeira officina, onde a par da instrucção technica ministrada pelos respectivos professores, cathedratico e substituto, são fabricados diariamente productos pharmaceuticos de habil confecção, o que contribue com igual passo para o solido preparo dos alumnos e progresso da industria nacional. (Mello Filho, 1909, p. 4). 
Estes debates na classe farmacêutica foram importantes para a regulamentação de suas profissões, com conseqüências para as práticas de terapia popular. Em uma mistura de saberes técnicos e populares, os farmacêuticos paulistas, também misturados com outros indivíduos que executavam as práticas de farmácia, modificaram o cenário das curas populares.

\subsection{Aproximações entre farmacêuticos ingleses e paulistas}

A profissão farmacêutica na Inglaterra foi estabelecida por meio dos embates entre os químicos e droguistas, somados às brigas com os apotecários e os cirurgiões. De maneira geral, o objetivo dos farmacêuticos era o de ganhar o espaço nas artes de formular medicamentos. Envolvidos na reforma médica do século XIX, travaram disputas frente às decisões parlamentares e às necessidades públicas em saúde. Já no estado de São Paulo, as modificações legislativas nas funções das profissões de saúde, como as de farmacêutico, inseriram-se na reforma sanitária de 1892, quando foi estabelecida a nova legislação sanitária no estado. Diferentemente do farmacêutico inglês, o farmacêutico paulista já era reconhecido pelas instâncias reguladoras como o profissional responsável pela manipulação de medicamentos quando da publicação do decreto n. 87, de 29 de julho de 1892. É possível que seu percurso profissional até o início da Primeira República tenha se dado de maneira similar ao que aconteceu na Inglaterra, a exemplo da função dos boticários, que atuaram principalmente no Império.

Nestas condições, farmacêuticos em São Paulo passaram a ser personalidades de saúde que atuaram em conjunto com outros profissionais dentro das mudanças em saúde. O item Do exercicio da medicina, da pharmacia, da obstetricia e da arte dentaria, contido no decreto n. 87 de 1892 é uma evidência de que estes profissionais tornavam-se importantes na regulação da manipulação, do comércio e do uso de medicamentos. Grande parte deste item focalizou as reformulações na profissão farmacêutica, se compararmos com a pequena quantidade de itens relativos às outras profissões, como as de medicina, obstetrícia e arte dentária. Por meio dos discursos científicos dos farmacêuticos, podem ter influenciado nas decisões governamentais do período republicano. Valeram-se da necessidade da população de outros cuidados com o uso de medicamentos, 'pressionando' autoridades legislativas para novas medidas contra o exercício de charlatães e a busca por fórmulas populares. Isto foi visível nas 
discussões observadas dentro dos periódicos científicos como a Revista Pharmaceutica. Por exemplo, o farmacêutico era responsável por criar fórmulas para o combate das doenças tropicais, ilustrado pelos achados de Cândido Fontoura.

Contrariamente, os profissionais farmacêuticos ingleses não foram personalidades envolvidas nas modificações legislativas ligadas à reforma sanitária da Inglaterra do século XIX de modo direto. Embora tenha havido uma organização de um serviço sanitário inglês, observado a partir da reforma sanitária de 1830, não foram inseridos como participantes pelas autoridades legislativas responsáveis pela reforma sanitária. Trabalharam especificamente por mudanças na reforma médica (Hanley, 1999; Gladstone, 1997; Smith, 1979), haja visto os embates entre eles e os outros profissionais de saúde, como os químicos e droguistas, apotecários e cirurgiões. Os discursos dos farmacêuticos ingleses embasavam-se, em sua maioria, em ataques dirigidos para as outras classes, como aconteceu com as disputas entre eles e os químicos e droguistas pelo poder de manipular as fórmulas. Tais ataques foram evidenciados em documentos do Parlamento inglês e em algumas publicações individuais destes profissionais. Não havia um canal comum de circulação científica, seja na classe farmacêutica, sejam nas classes dos apotecários ou dos químicos e droguistas, conforme aconteceu com a profissão farmacêutica em São Paulo, ilustrada principalmente no periódico Revista Pharmaceutica.

Além das discussões nos periódicos da classe farmacêutica em São Paulo, o desenvolvimento das farmácias e da indústria farmacêutica conectaram-se com as mudanças profissionais dos farmacêuticos paulistas. Em grande parte do período selecionado, percebeu-se relação importante do processo de desenvolvimento de sua profissão em consonância com o processo de entrada da indústria de medicamentos no estado. Por exemplo, as adulterações cometidas especialmente com produtos farmacêuticos industriais, feita por profissionais com ou sem qualificação farmacêutica técnica.

Ao passo que na Inglaterra as fraudes concentraram-se com medicamentos de natureza não-industrial (principalmente o que os ingleses chamaram de medicamentos comerciais e patenteados), executadas por indivíduos, em sua maioria, desprovidos de qualificação técnica. Especialmente químicos e droguistas foram as principais personalidades vinculadas a este comércio de medicamentos. Os medicamentos industriais foram pouco mencionados ao longo do século XIX pelas autoridades parlamentares. Ademais, não observamos os discursos dos farmacêuticos ingleses 
frente ao problema de manipulação, venda e uso de medicamentos, como encontramos em São Paulo, onde os farmacêuticos participaram com relevância dos embates sobre o tema. Evidenciamos o predomínio de discursos das autoridades parlamentares sobre a questão da produção, do comércio e do uso de medicamentos. O Ato dos Apotecários de 1815 e o Ato Farmacêutico de 1852 foram algumas determinações mencionadas, concedidas pelo Parlamento.

Interpretamos este fato em virtude dos momentos diferentes em que as duas regiões se inseriam. O estado de São Paulo sentiu os reflexos industriais na área farmacêutica por conta do desenvolvimento concomitante das indústrias e da profissão farmacêutica. Segundo Edler (2006), "O aparecimento das drogas industrializadas se deve à emergência da profissão farmacêutica. Ao combinar as habilidades e competências dos boticários, botânicos e químicos, ela permitiu o avanço do conhecimento sobre as drogas.” (p. 86).

$\mathrm{Na}$ Inglaterra, observamos a não-sincronização da profissão farmacêutica ao desenvolvimento industrial de medicamentos. Farmacêuticos ingleses e medicamentos produzidos pela indústria não andaram lado-a-lado, como vimos acontecer em São Paulo, apesar da fase inicial de desenvolvimento industrial aqui. É possível que a indústria de medicamentos inglesa já estivesse mais 'à frente', mais desenvolvida: um exemplo foram as determinações parlamentares de impostos sobre os medicamentos industriais, que existiam desde o final do século XVIII, e já regulamentavam leis para os medicamentos industrializados.

Isto passa a ser importante se atentarmos para o fato de que as regulamentações sobre o uso e o comércio de medicamentos no século XIX, determinadas pelo Parlamento britânico, concentraram-se nos medicamentos 'que não seguiam um livro de referência'. Eram aqueles medicamentos comerciais e patenteados (não-industriais) apontados ao longo de nossa investigação. Se fizermos uma comparação com o estado de São Paulo, a taxação de medicamentos começou somente no final do século XIX, justamente o período em que a indústria farmacêutica dava seus passos iniciais.

Neste contexto, farmacêuticos foram personalidades importantes nas duas localidades em questão. Modificavam a saúde da população, ganhando espaço na área de saúde de cada local, fazendo suas profissões se tornarem conhecidas e confiáveis, por meio de seus atributos técnicos. Em São Paulo, discutiram com autoridades governamentais para controlar o charlatão que exercia a manipulação de fórmulas. $\mathrm{Na}$ 
Inglaterra, os farmacêuticos recebiam concessões parlamentares para o exercício de sua profissão, e isso contribuiu para que as artes de cura populares, especialmente dos químicos e droguistas, fossem substituídas pelo caráter 'diplomado' do profissional farmacêutico inglês.

Por último, as determinações legais, tanto em São Paulo como na Inglaterra, mostraram um trabalho governamental antagônico no controle das práticas de cura populares: ora a legislação pendia para uma posição a favor do desenvolvimento da farmácia científica, contribuindo para o desenvolvimento da profissão farmacêutica, ora legitimava as práticas da farmácia popular. Isso foi observado através de algumas evidências como a permissão da manipulação de fórmulas por pessoas sem diploma de farmacêutico em São Paulo; na Inglaterra, a consideração de que os charlatães ingleses, como os químicos e droguistas, podiam dar conselhos médicos. Em paralelo, as determinações legais, como o Ato Farmacêutico de 1852 na Inglaterra e o decreto n. 87 de 1892 em São Paulo, incentivaram o processo de progresso científico na área de farmácia. 


\section{Médicos em São Paulo e na Inglaterra}

\subsection{Em São Paulo}

Como na área farmacêutica, a legislação sanitária de 1892 criava novas diretrizes para a função de médicos na área da saúde. Algumas das questões que influenciaram no papel destes médicos dentro da saúde pública paulista foram o combate ao charlatanismo, às práticas médicas não oficializadas e às terapias populares do período. Machado e colaboradores (1978) ressaltaram também que as preocupações com a higiene do país envolveram a classe médica, na medida em que esta classe acabou por intervir nas decisões políticas do Brasil, não somente no período imperial, como também na época republicana.

Nestas condições, médicos, seguidos de farmacêuticos ${ }^{59}$, formavam um grupo de profissionais que recebiam novas direções em relação às suas atividades no final do século XIX. O capítulo XII do decreto n. 87 de 29 de julho de 1892 ressalta, em seu artigo 25 , que

Só é permitido o exercício da arte de curar em qualquer de seus ramos e por qualquer de suas formas:

I. Ás pessoas que se mostrarem habilitadas por título conferido pelas Faculdades de Medicina da República dos Estados Unidos do Brasil. (Carvalho, 1892, p. 154).

Além disso, médicos, à semelhança dos farmacêuticos, também deveriam se matricular na Diretoria de Higiene, com a apresentação de seus respectivos títulos ou licenças. Esta Diretoria era incumbida, ainda, de publicar uma relação dos profissionais matriculados, com revisão anual da lista. Estes médicos começavam a ganhar importância na medicina do final do século XIX. Por exemplo, quando parteiras eram chamadas para conduzir os partos, estas mulheres podiam somente prestar os cuidados primários às parturientes e aos recém-nascidos; cuidados mais específicos eram direcionados aos médicos. Conforme a publicação de 1892:

Em caso de distócia deverão sem demora reclamar a presença do médico e, até que êste se apresente, empregarão tão sómente os meios conhecidos para prevenir qualquer acidente, que possa comprometer a vida da parturiente ou a do feto.

São-lhes proibidos:

\footnotetext{
${ }^{59}$ Parteiras, cirurgiões e dentistas também eram profssionais de saúde que estavam inseridos nas mudanças profissionais do serviço sanitário em 1892.
} 
O tratamento médico ou cirúrgico das moléstias das mulheres ou das crianças; os anúncios de consultas e as receitas, salvo de medicamentos destinados a evitar ou combater acidentes graves que comprometam a vida da parturiente ou a do feto ou recém-nascido. Tais receitas deverão ter a declaração de "urgente”. (Carvalho, 1892, p. 155).

Esta proibição estava ligada ao fato das parteiras serem consideradas mulheres 'nãohabilitadas' tecnicamente para o exercício da medicina: não possuíam certificado profissional, e por isso faziam parte do grupo que praticava 'terapia popular'. Segundo discurso de um médico 'diplomado', o Dr. Candido Espinheira (1898), estas parteiras, juntamente com outros terapeutas populares, cometiam abusos por exercerem ilegalmente a medicina, a farmácia, a obstetrícia e a arte dentária.

Algumas restrições e permissões de práticas de saúde dos médicos foram especialmente enfatizadas em relação ao papel dos farmacêuticos, em geral anulando a função de um profissional quando o outro era contemplado com tal função. Não era permitido, por exemplo, o exercício da medicina e da farmácia pelo mesmo profissional, mesmo que o médico possuísse título de farmacêutico, mas era facultado ao médico exercer a farmácia em alguns casos:

Nos logares, porém, em que não houver pharmacias, e quando estas estiverem pelo menos a 3 kilometros de distancia, sendo urgente a administração de medicamentos, poderá o medico fornecel-os, sem que por isso lhe assista o direito de ter pharmacia aberta ao publico. (Toledo, 1896, p. 47).

Estas primeiras determinações governamentais contemplavam as atividades tanto de médicos como de farmacêuticos. Como a função dos médicos era a de diagnosticar doenças e de prescrever medicamentos, e a do farmacêutico de manipular as fórmulas prescritas pelos médicos, seus papéis na sociedade paulista, em geral, complementavam-se. Assim, as duas classes de profissionais ora mostravam sincronia nos trabalhos em conjunto, ora mostravam atritos. Um farmacêutico publicou um discurso em que demonstrava 'solidariedade' aos médicos em relação à produção de medicamentos que ele considerava excessiva pela indústria farmacêutica, atentando que, 
O papel do medico é prevenir as moléstias, as curas ou pelo menos mitigar os soffrimentos e com um diminuto numero de medicamentos bem conhecidos chegarse-há a meta dezejada sem ser preciso lançar mão destes ramos disfarçados que brotam dos laboratórios industriaes os quaes muitas vezes vem contribuir para desorientar o clinico observador. (Vasconcellos \& Hollanda, 1899, p. 54).

A situação contrária também acontecia, com médicos 'defendendo' a classe farmacêutica. Declararam que em algumas situações excepcionais em que não houvesse o auxílio do médico, o farmacêutico deveria socorrer o doente, e não poderia ser confundido com um charlatão: assim, contribuiria com seu "...auxilio precioso..." (Rocha, 1928, p. 38). Declararam ainda que

O papel que o pharmaceutico representa na sociedade é muito elevado. É um indispensavel collaborador do medico, sem o qual este ultimo ficaria completamente tolhido do desempenho da sua missão.

Dahi, a necessidade absoluta do bom entendimento entre as duas classes, que quasi podem ser fundidas n'uma só, uma vez que trabalham para o mesmo fim.

(Rocha, 1928, p. 39).

Ao mesmo tempo, havia alguns embates não apenas entre as profissões de médicos e de farmacêuticos, mas também entre médicos e outros profissionais, como os cirurgiões ${ }^{60}$. Médicos, na maior parte de seus discursos, consideravam-se mais capazes de exercer determinadas funções de medicina em detrimento do exercício de outros profissionais. Brouardel (1898) relatou o fato de serem 'protegidos' pela legislação, em detrimento de cirurgiões, por exemplo, que na época não eram reconhecidos legalmente. O relato foi dado pelo parlamento de Bordéos, na França, em 1760:

...todas as penas severas são para os cirurgiões, e em geral os medicos são absolvidos ou apenas levemente admoestados. (p. 169).

O mesmo autor enfatiza que a punição por erro do médico é muito leve, deixando de proteger o doente em caso de acidente médico:

\footnotetext{
${ }^{60}$ Apesar de cirurgiões estarem inseridos nas mudanças legislativas das profissões de saúde, foram muito poucas as atribuições regulamentadas pelo serviço sanitário de São Paulo para o seu exercício no período 1892-1930. Possuíam um papel de pouca relevância na sociedade dessa época, se compararmos com os cirurgiões ingleses, que modificaram o cenário médico do século XIX na Inglaterra.
} 
$\mathrm{Na}$ America, onde a liberdade do exercicio na medicina é absoluta, a responsabilidade medica entra no direito comum. Em caso de insucesso ou de morte, os medicos são as vezes condemnados a indemninsações consideraveis, 100.000 o 150.000 francos. Frequentemente, os medicos fazem os doentes assignar, antes da operação, o compromisso em seu nome e no de seus herdeiros de nada reclamar, qualquer que seja o resultado da operação. Esse processo, si colloca o medico em segurança, não dá garantias ao doente. (p.

170-171).

Em relação aos profissionais farmacêuticos, médicos também mostravam certo desconforto, especialmente quando consideravam os farmacêuticos como os 'charlatães dos medicamentos'. Alegavam que, a despeito de sua importante colaboração na saúde, o ensino farmacêutico havia decaído muito, e que este fato contribuía para que farmacêuticos deixassem seus locais de atuação 'séria' para se aventurarem como farmacêuticos curandeiros:

\footnotetext{
Temos então, com todas as suas consequencias, a pratica ignobil de uma therapeutica symptomatica bebida ao accaso n'um Chernoviz ou em qualquer formulario sebento, e applicada "á la diable”: Toda diarrhéa é susceptivel de bismutho ou tannino. O doente tosse? - xaropes com morphina ou qualquer outro derivado do opio. (Rocha, 1928, p. 40).
}

A legitimação dos médicos na saúde pública crescia, indicando que seu papel na sociedade paulista da Primeira República era mais importante do que as funções de outros profissionais de saúde. Almejava-se combater as práticas de pessoas que atuavam como 'médicos', por meio da promoção profissional dos médicos na área de medicina. Conforme já mencionado, os médicos desejavam combater quaisquer tipos de homens que praticavam suas artes de cura populares, que ficavam longe do desenvolvimento científico que crescia na área médica. Isso era bastante frequente nos discursos médicos publicados nas revistas científicas médicas durante todo o período da Primeira República. Segundo o discurso do Dr. Oscar Freire (1920),

O curandeirismo, typo obrigado nas cidades do paiz, era, dantes, simples, humilde e sincero. Com o progresso impou, criou philaucia, appareceu á luz do dia, fingindo convicções para engodar basbaques. O seu avoengo, o conhecido 
typo do curandeiro, africano ou cabloco, pelo menos tinha a attenuante da sinceridade; na sua arrevesada therapeutica de rezas e mezinhas, de orações e preceitos, havia um fundo religioso, preitimivo mas sincero, facil de rastrear sob as formas de mimetismo ede mestiçagem psychologica sob que se mostrava. $O$ actual é apenas um explorador, que cava despudoradamente no aureo filão que lhe deparam os resquicios de feiticismo que remanescem no substrato de todos os espiritos. E tem uma influencia perniciosa sobre a pratica de nossa profissão: absorve avultada clientela dos medicos, nutre-a de erros, enfermando-a de crendices e abusões, desmoralisando-a em summa. (p. 17).

Os médicos incomodavam-se também com a presença de seus pares estrangeiros, e tentaram diminuir a importância de médicos de outros países na medicina de São Paulo. A Lei n. 240 de 1893, que reorganizou o Serviço Sanitário no Estado de São Paulo, conferiu a participação de médicos estrangeiros no estado, especialmente quando as profissões médicas apresentassem:

2. ${ }^{\circ}$ Ás que, sendo graduadas por escolas ou universidades estrangeiras conhecidas, se habilitarem perante as ditas Faculdades na fórma dos estatutos respectivos. 3. ${ }^{\circ}$ Ás que sendo ou tendo sido professores de escola ou universidades estrangeiras reconhecidas officialmente, requererem ao Governo licença para o exercicio da profissão, a qual poder-lhe-á ser concedida, si exhibirem documentos comprobatorios da qualidade de professores e de terem exercido clinica, devidamente authenticados pelo representante diplomatico da Republica, e na falta pelo consul brazileiro. 4. Ás que, sendo graduadas por instituições estrangeiras, provarem que são auctores de obras de merecimento de medicina, cirurgia e pharmacologia e requererem licença ao Governo que lhes poderá conceder, depois de ouvir uma das Faculdades da Republica.” (Gurgel, 1893, p. 168).

De fato, uma parte dos profissionais de saúde no final do século XIX provinham de países europeus, principalmente da França e da Inglaterra. Especialmente no início do século XIX foi observada uma aproximação com estes dois países, muito por conta da estratégia portuguesa em trocar informações com o velho mundo (Kury, 2004). As próprias revistas científicas brasileiras reportavam avanços da comunidade local devido à influência estrangeira. A idéia de desenvolvimento estava associada à cópia dos métodos de saúde franceses e ingleses (Sociedade Pharmaceutica Paulista, 1895, p. 41). 
Ao mesmo tempo, havia um desconforto de médicos paulistas em relação à legalização profissional de estrangeiros. O periódico São Paulo Medico (1929-30) destacou na seção "Commentarios" que a habilitação de médicos de outros países deveria ser analisada com mais cautela, alegando que o ensino médico era diferente em cada localidade. Acrescentou ainda que tais médicos estrangeiros envolviam-se em "...competições financeiras..." devido ao aumento da concorrência entre os profissionais (p. 522); em questões do ensino médico, ocorriam fraudes, conforme descreve um médico brasileiro do mesmo periódico:

Como se vê, a exigencia maxima é a apresentação de 3 theses sobre assumptos do curso medico e a sua defesa oral. Quem sabe quanto é facil a obtenção de uma these "sob encommenda", acompanhada dos esclarecimentos necessarios á sua defesa, não deixará de pasmar ante a innocuidade desse systema de revalidação. (p. 524).

Talvez nossos médicos não estivessem passando por uma influência estrangeira na medicina de São Paulo, e sim por um desenvolvimento da área médica aqui que corria em paralelo aos avanços da medicina de fora. Talvez a questão do combate ao charlatanismo tenha despertado nos médicos paulistas esse crescimento da medicina científica, para melhorar as lacunas técnicas que existiam na área médica. Segundo Mott e colaboradores (2008), o número de médicos registrados de 1892 a 1932 no serviço sanitário foi aumentando, e a elevação no pós-guerra foi ainda mais considerável. Salles (2006) argumenta que tal aumento aconteceu pela entrada no mercado de trabalho dos formados pela Faculdade de Medicina e Cirurgia de São Paulo. Somado a isso, muitos regressaram do exterior com diplomas de instituições estrangeiras neste período (Mott et al., 2008).

É possível, então, que esse aumento no número de médicos formados após a Primeira Guerra possa ter sido consequência da necessidade em se formar mais e melhores médicos, conforme apontamos. Isto seria alcançado tanto para deslegitimar as práticas dos terapeutas do povo como para normatizar a própria profissão de médico. Por exemplo, as 'ruindades' da guerra pediam profissionais mais habilitados pra trabalhar com as sequelas das batalhas em campo. Segundo Montenegro (1919), que chefiou a "Missão Medica Militar Brazileira que foi á França", 
Se o Brasil tivesse de tomar parte na guerra que acaba de findar, teria que luctar com difficuldades insuperaveis. (p. 72-73),

em alusão à falta de preparo médico de nosso exército. Tomou como referência as organizações hospitalares observadas nos fronts americanos e ingleses. Ressaltou a importância do posicionamento profissional de médicos, cirurgiões e enfermeiras, bem como dos equipamentos médicos adequados levados para a guerra e da infraestrutura para acolher os doentes da guerra.

Nestas condições, carência e presença de médicos foram pontos antagônicos naquele período, causando desconforto na população que não conhecia muito bem o trabalho deste profissional. Mais que isso, era a própria vontade dos médicos da legitimação de sua profissão que causavam as disputas. Os próprios profissionais discutiam a desonestidade e a falta de credulidade de seus colegas, que eram chamados de charlatães médicos. Segundo Favero (1928), a população buscava um curandeiro, por exemplo, porque preferia receber um tratamento 'espiritual' ao invés de uma terapia medicamentosa 'científica'. Houve uma classificação dos vários tipos de charlatães, curandeiros e do exercício ilegal da medicina, para facilitar a punição dos mesmos pelas vias penais em vigor na época: charlatão consciente, charlatão inconsciente; curandeiro que "...ministra remedios...", curandeiro que "...receita apenas..." (p. 202); no exercício ilegal da medicina, eram médicos diplomados mas que não possuíam certificado do Brasil, ou possuíam, mas de escolas não reconhecidas legalmente.

De fato, um médico chamado Dr. Viriato Brandão (1903) publicou um estudo sobre a Davilla rugosa, planta da flora brasileira, destacando o processo de produção popular de um medicamento por meio desta planta:

Este processo, commum em medicina popular não pode servir em medicina scientifica. Para que esse medicamento possa servir nos usos medicos correntes, é necessario dar-lhe a forma pharmaceutica, e, de tudo, assegurar-lhe a identidade por meio da classificação botanica. (p. 335).

Outro médico, o Dr. Oscar Freire (1920), enfatizou que receava mais, “...pela extensão dos seus malefícios, o medico charlatão do que o charlatão curandeiro." (p. 21). Reforçou que "A sabedoria popular pintou a estrada do dever ingreme, aspera, 
difficil e, sobretudo, longa. A deshonestidade e o desescrupulo têm atalhos por toda a parte." (p. 21), em alusão aos perigos que o 'mercantilismo' trazia para a medicina, onde muitos médicos só almejavam lucrar com sua atividades médicas, trabalhando de maneira egoísta e individual. Apontou que este profissional,

Sitiado por concorrencia asphyxiante, immerso numa luta febril, nem sempre leal, póde-se ir entranhando no espirito do medico um pernicioso individualismo. Se triumphou, porque attingiu á meta sósinho, sem ajuda, despreza indifferente o confrade vencido. (p. 22).

Além disso, a falta de médicos especializados para lidar com as questões de saúde, que foi uma grande preocupação na época, bem como a ausência de escolas de higiene no Brasil, dificultavam o desenvolvimento da profissão médica. Até a década de 20, grande parte das ações médicas era pautada no controle das doenças transmissíveis. Um destaque, entretanto, enfatiza o ensino de Higiene na Faculdade de Medicina de São Paulo, “...executado em condições de bôa eficiencia pratica, sob a direção dos especialistas americanos Drs. Darling e Smillie, por acôrdo com a Fundação Rockefeller." (Fontenelle, 1941, p. 21).

Mesmo assim, o país como um todo carecia de recursos técnicos e financeiros para formar médicos ligados à área de higiene com algum reconhecimento pela sociedade. De acordo com Fontenelle (1941), os médicos precisavam de

...vencimentos que permitam, sem auxilio da clinica, viver honestamente. Nossas repartições de higiene, em geral, teem visto crescer, com enorme rapidez, os seus gastos, sem vantagens que compensem por completo esses grandes onus financeiro,... (p. 27).

Por conta destas dificuldades, estes profissionais tentavam se colocar na sociedade paulista por meio de discursos enfatizando a importância de se combater as práticas populares de terapeutas. Faziam discursos voltados para sua intensa dedicação médica, dedicação sem objetivar o lucro: colocavam-se como figuras milagrosas, dando, à sua profissão, uma denotação religiosa. O Dr. Fernando de Magalhães (1918) publicou um discurso enfatizando a importância da profissão médica na sociedade: argumentou que possuíam um poder quase religioso ao cuidar das pessoas, renunciando o ganho financeiro elevado, combatendo as fraudes e as 
charlatanices de saúde. Disse que o papel dos médicos era de aguentar “...as figuras sinistras que a profissão tolera pela attitude que escolhem, revivendo a audacia perigosa dos innovadores, ostentando a omnipotencia dos mesinheiros, eternizando a raça execrada dos traficantes e a miseria repulsiva dos dissolutos." (p. 34).

Ainda reforça este poder de 'sacerdote' falando que " $E$ a sciencia confiando na consolação e na cura. É a dignidade que exige o culto deste prestigio millenario de que falla a escriptura, mandando honrar o medico por amor á necessidade, porque Deus o creou á elle." (p. 33-34). Diz ainda para os médicos: "Não esqueçais que ella tem tanto do sacerdocio como da profissão..." (p. 34). E finaliza o discurso falando que tais profissionais possuem a "...missão de evangelizar...", e "No mister da vossa profissão sereis os semeadores da boa palavra e da boa doutrina, dareis vigor ao combalido, força ao inerme, saude ao doente, alento ao fraco, ensino ao inculto, crença ao insensivel, opinião ao inutil, liberdade ao individuo, consciencia ao cidadão." (p. 34).

Tentaram combater estes charlatães e todos os outros meios de alternativas populares 'denunciando', por meio de argumentações contra tais práticas, nas próprias revistas científicas médicas: o Dr. Eurico Ribeiro (1928) atenta que os anúncios de medicamentos em jornais, panfletos, folhetos, cartazes, placas e letreiros davam a possibilidade para pessoas não qualificadas de anunciar seus medicamentos milagrosos, os quais não possuíam eficiência terapêutica. Destacou as falhas na legilação em curso no período:

É deficiente porque apenas prohibe a publicação de annuncios relativos a medicamento não approvados pela Diretoria Geral de Saude Publica; é sabido que um medicamento approvado pode ser annunciado em termos inconvenientes, constituindo perigo para a saude publica, que o legislador não defende quando exposta a essa possibilidade de verificação corriqueira.

É deficiente porque, prohibindo a publicação de annuncios "relativos a tratamentos ou curas não confirmados por profissionaes”, expõe ao sophisma dos curandeiros de annunciarem casos por elles tratados e cuja cura foi "confirmada por um profissional" habilitado (qualificativo que a lei prescinde, talvez com prejuizo dos seus propositos). (p. 319).

Considerou que era preciso controlar diretamente os indivíduos que publicavam tais anúncios, por meio de orientações e punições, em caso de necessidade. No 
documento, sugere ainda às autoridades responsáveis um projeto de lei, onde destaca as principais sugestões para que tais excessos sejam melhor controlados pelo estado. Ao final, o médico acrescenta que

Esse serviço será dirigido por um chefe technico, que deverá ser um medico hygienista e que será auxiliado por um archivista e por um dactylographo; a secção terá, tambem, um servente. (Ribeiro, 1928, p. 331).

Na realidade, o que se sugere é que havia uma necessidade desta classe profissional de se afirmar frente às instâncias governamentais, pressionando-a para que nas decisões políticas se considerassem não somente as mudanças às quais a saúde pública necessitava, como também o papel que médicos possuíam no cuidado à saúde. Fica evidente tal necessidade quando o Dr. Ribeiro (1928) sugere a forma como se deveria mudar a legislação:

Melhor seria, sem duvida, que o legislador generalizasse assim a prohibição necessaria.... (p. 320).

De fato, os médicos ganhavam um espaço diferenciado com o estabelecimento da legislação sanitária a partir do final do século XIX. A legitimação médica ao longo das mudanças legislativas, especialmente após 1915, foi mostrada, por exemplo, quando médicos discutiam os benefícios de suas descobertas. O Dr. F. C. P. ${ }^{61}$ (1923) mencionou o discurso do professor Aguiar Pupo quando palestrou na Sociedade de Medicina de S. Paulo:

A primazia da realização pratica de medidas contra a syphilis, cabe ao Serviço Sanitario do Estado de S. Paulo, que em 1918, na administração Arthur Neiva, creou 5 postos de prophylaxia e tratamento gratuito da syphilis, attendendo a honrosa iniciativa do Centro Academico "Oswaldo Cruz" e do Gremio dos Internos dos Hospitaes, associações de estudantes da Faculdade de Medicina e Cirurgia de S. Paulo. (p. 21).

Estas novas regulamentações em São Paulo foram criando a possibilidade destes médicos tornarem-se profissionais importantes em cargos de assistência, de

\footnotetext{
${ }^{61}$ Também não foi encontrado o nome por extenso deste médico.
} 
chefia e de diretoria em órgãos que passavam também por reformulações em suas bases administrativas, gerando atrito com outros profissionais de saúde. Um exemplar deste embate foi quando um projeto de reforma sanitária tirou o cargo de assistente do Instituto Bacteriológico dos profissionais farmacêuticos, restringindo a assistência somente aos médicos. O farmacêutico D. V. ${ }^{62}$ (1917) reclama que

Vê-se claramente nesses medicos senão o proposito deliberado de amesquinhar uma classe, pelo menos o grande desprezo que por ela têm os nossos dirigentes.

(p. 146).

Inquiriam, ademais, a necessidade de se estabelecer um sindicato médico, pois isto ajudaria, segundo tais profissionais, a controlar a ação dos médicos populares. Conforme o médico Jayme Pereira (1929) apontou, uma das atribuições deste sindicato era a de combater as ações ligadas ao "...exercicio illegal da medicina, aos curanderismos, ao charlatanismo e ás demais praticas deshonestas da medicina..." (p. 200). Todas estas ações presentes na nova legislação acabaram por beneficiar os médicos em sua atuação na saúde da população, o que pode ter funcionado como uma barreira para aqueles que praticavam as artes de cura populares. Para ilustrar as charlatanices, os médicos regularmente publicavam documentos contendo exemplos de casos mal-sucedidos de charlatães que exerciam as artes de cura:

De outra feita, appareceu-nos no consultorio uma mulher do povo, portadora de um tumor maligno na face.

Ao desembrulhar o curativo, encontrei sobre a ferida um "filet" de carne de vacca, ahi collocado a conselho de um curandeiro, que assim tinha procedido para "distrahir a attenção dos bichos, que emquanto comiam a carne de vacca, deixavam em socego a da doente”! (Rocha, 1928, p. 35).

A despeito dessas pressões da classe médica, todo o período republicano foi um misto destas práticas populares e dos embates de médicos, que almejavam maior participação não somente em questões de saúde pública, mas também na vida política dessa sociedade, especialmente em questões de higiene. Conforme Fontenelle (1941) aponta, "O medico que se dedica à arte de curar tem que ser cirurgião, pediatra,

\footnotetext{
${ }^{62} \mathrm{O}$ nome por extenso deste farmacêutico também não foi encontrado.
} 
ginecologista, dermatologista, oftalmologista, obstetra, etc., e si quizer entregar-se aos trabalhos de higiene publica terá perdido muito tempo em aprender varias disciplinas que de nada the servirão, do mesmo passo que the vão faltar conhecimentos de outra natureza: questões de engenharia, de administração, de jurisprudência, de sociologia, etc. A educação, a pratica, as idéas, os pontos de vista e os objetivos de um bom clinico são absolutamente diversos dos de um perfeito especialista de higiene." (p. 20). Essa participação em questões indiretamente relacionadas à medicina aconteceram para legitimar cada vez mais a importância do profissional médico em diversas áreas de atuação. Isso teve um reflexo nas atividades populares de cura, uma vez que quanto mais a autoridade médica se instalava na sociedade paulista da primeira república, menor era a força da medicina popular praticada pela população.

Por exemplo, um regulamento baixado para estes médicos dirigirem algumas instituições, como maternidades e casas de saúde, propiciaria uma diminuição de práticas ilegais, que eram conduzidas nestes próprios estabelecimentos:

\footnotetext{
As maternidades e casas de saúde só poderão funcionar debaixo da direção de um médico responsável perante a diretoria de higiene, por tudo quanto nas mesmas ocorrer sob o ponto de vista sanitário. (Carvalho, 29 jul 1892, p. 153).
}

Ressaltava-se, ainda, a importância de controlar os casos de abortos criminosos e de doenças puerperais ou transmissíveis nestes locais: estas fiscalizações ficariam também nas mãos destes médicos. Em caso de ocorrência de algum destes eventos, entretanto, a cassação da licença do profissional seria requerida (Carvalho, 29 jul 1892). Seis anos depois, a lei n. 432, de 3 de agosto de 1896, regulamentou que:

\footnotetext{
Nenhuma casa de saúde ou hospital poderá funccionar sem ter um médico interno residente no edificio ou tão proximo que possa acudir a qualquer accidente. Nenhum estabelecimento de applicações hydrotherapicas ou de electricidade medica poderá funccionar sem ter um medico assistente para fiscalizar a applicação e se responsabilizar por ella. (Bueno, 1896, p. 53).
}

As autoridades governamentais concediam, ao mesmo tempo, benefícios para tais médicos, mas tentavam controlar também suas atividades. 
Esse crescimento na importância da profissão médica na Primeira República foi reforçado quando da recriação da Escola de Medicina e Cirurgia em 1912 em São Paulo: o objetivo era de formar a educação médica no próprio estado. Mas a criação desta escola mostrou um processo bastante demorado, pois os alunos assistiam às aulas teóricas, mas a escola ainda não possuía laboratórios e nem um hospital (Marinho, 2006; Mota, 2005). Por exemplo, a autorização da construção do edifício para esta faculdade só foi acontecer em 1916, com a lei n. 1504, de 17 de outubro de 1916:

Artigo 1. ${ }^{\circ}$ - Fica o Governo do Estado auctorizado a construir nesta Capital um edificio para a Faculdade de Medicina e Cirurgia de S. Paulo e a fazer as despesas necessarias para a conveniente installação da mesma, dos gabinetes, dos laboratorios e de tudo o que fôr preciso para o ensino nella ministrado. (Reis, 18 out 1916, p. 7$)$.

Antes da fundação desta escola, porém, uns embates ocorreram para o surgimento desta instituição: médicos e farmacêuticos discordavam entre si sobre a fundação de uma escola de medicina e de farmácia. Desejavam a criação de uma escola única, onde cada estudante cursaria seus respectivos cursos ${ }^{63}$. De fato, as divergências para a criação da Escola Livre de Pharmacia em 1898 mostram apoio e reprovação da classe médica diante do desejo de farmacêuticos em se estabelecer uma escola de farmácia. Segundo Souza (1904), os médicos demonstraram aprovação na criação desta escola por meio de publicação na Revista Medica de S. Paulo:

A 15 de Agosto do mesmo anno, em artigo da redacção, a-Revista Medica de S. Paulo - occupa-se do assumpto e julga de magno interesse a creação dessa Escola, cujo raio de acção e de vantagens mui provavelmente extender-se-ia a todo territorio nacional. Reconhece a necessidade de tal creação, ampara a idéa já inserta nos Estatutos da - Sociedade Pharmaceutica -, concita o Governo a prestar todo o seu auxilio e lembra que a ella estando annexada uma - Escola ou Curso de Veterinaria - com isso não só lucraria o Estado, como, mais tarde, semelhante Instituição poderia ser o centro de partida, o nucleo gerador da -

\footnotetext{
${ }^{63}$ M. L. Mott, I. G. Duarte e M. T. Gomes fizeram um levantamento de documentos da coleção "Universidade de São Paulo" do Arquivo do Estado de São Paulo em que diversas evidências sobre a criação da Escola Livre de Pharmacia de São Paulo foram encontradas. Consultar: Montando um quebra-cabeça: a coleção "Universidade de São Paulo" do Arquivo Público do Estado de São Paulo. Cadernos de História da Ciência, vol. 3, n. 2, p. 37-72, julho-dezembro 2007.
} 
Escola de Medicina - ponto contrario aos intuitos da - Sociedade Pharmaceutica.

(p. 13-14).

De fato, em anos seguintes, a Revista Medica de S. Paulo (1900) publicou o decreto n. 780 de 26 de abril de 1900, onde há a aprovação do regulamento da Escola Livre de Pharmacia em São Paulo. Ao mesmo tempo, tais médicos demonstraram desconfiança na criação dessa escola. De acordo com o relato de um farmacêutico, um médico, de autoria desconhecida, publicou, na Revista Medica de 15 de outubro de 1898, notas reprovando tal criação:

Além disso, não posso comprehender que razões tão poderosas, de tão alta valia, conduziram o auctor a tanta injustiça; que interesses tão elevados poderão ser contrariados, si a - Escola de Pharmacia - alargando o ambito dos seus cursos, exetendendo os horizontes do ensino, chegar um dia a erigir o magestoso edificio de uma - Faculdade de Medicina - respeitando todos os direitos e conservando nos seus respectivos postos todos aquelles que valorosamente se têem empenhado, para fazel-a attingir o gráo de adeantamento que hoje desassombradamente póde assignalar!?

Como pois explicar-se tão ferrenha antipathia, tão systematica opposição?

(Souza, 1904, p. 15-16).

Entre concordâncias e discordâncias, portanto, os médicos conseguiram estabelecer a sua faculdade de medicina em São Paulo, e isso foi decisivo para o crescimento da profissão médica ao longo do século XX. O desenvolvimento do conhecimento médico por meio da instalação dessa escola de medicina era uma forma de normatizar a profissão aos poucos, crescendo o espaço destes profissionais na sociedade paulista, o que acarretaria em um enfraquecimento das práticas daqueles charlatães, já que as autoridades governamentais estavam criando esse espaço para a classe médica. No próprio discurso de médicos que ensinavam os jovens estudantes de medicina, havia um tom forte contra esse tipo de prática de cura popular, e ilustramos aqui por meio das palavras do professor Rubião Meira (1920) em uma conferência para os alunos ingressantes no curso:

Quereis conhecer os vossos deveres e os vossos direitos, examinar questões que preoccupam o vosso entendimento, como as que se referem á liberdade profissional objecto debatido onde inda se não quietou a poeira da controversia, ao charlatanismo 
- essa praga que nos tortura e nos vilependia tantas vezes no trafego profissional - ao segredo medico, com todas as minucias, que, em cada caso, nos deixam perplexos na maneira de proceder; aos honorarios de nossos serviços, quasi sempre menoscabados pelos que deviam respeitar, no clinico, o sacerdote devotado que a todo minuto joga a sua vida; ás responsabilidades que tomamos sobre os hombros...(p. 7-8).

Os jovens estudantes ainda eram ensinados a cuidar de todos os tipos de pessoas, independente do indivíduo ser “...bom individuo ou se é um criminoso...” (p. 11), para que assumissem “...na existencia a posição invejavel em que o collocam sua sciencia, seu trabalho, suas aptidões, seus esforços em prol da humanidade. Nem de outro modo elle pode esmagar - sob o peso de sua superioridade - os que desconhecem a sua elevação moral, a magestade de sua figura." (p. 13).

Essa legitimação da profissão médica também foi beneficiada com o desenvolvimento científico da medicina, por meio do surgimento das primeiras revistas médicas ${ }^{64}$ de São Paulo, especialmente a partir do final do século XIX. A Revista Medica de São Paulo foi uma das primeiras a se destacar, em meados de 1889. Nos anos seguintes, uma série de outros documentos foi surgindo, como o Boletim da Sociedade de Medicina e Cirurgia de São Paulo, a Gazeta Clínica, a Imprensa Médica (Silva, 2003, p. 89). A publicação destas revistas corrobora as transformações da profissão médica aliada ao progresso científico: novos estudos e descobertas relacionados a doenças e tratamentos, com foco na saúde da população; mas mais importante que o desenvolvimento de métodos médicos foi a demonstração que tais periódicos médicos mostraram: a vontade desses médicos de estabelecer seu espaço no âmbito nacional. Segundo Mota (2005), os médicos faziam parte de uma classe profissional em ascensão, muito capaz de sanar os problemas de saúde da população.

O primeiro congresso médico em São Paulo, realizado em 1916, confirma o processo de transformação do espaço médico, com a união destes profissionais em torno de um espaço científico para se discutir os problemas de saúde da população, em conjunto com as novas descobertas científicas. Nos anais deste congresso, podem ser encontradas conferências ministradas por médicos da época como o Dr. Emilio

\footnotetext{
${ }^{64}$ Anais Demográficos de São Paulo, Boletim do Instituto de Higiene de São Paulo, Anais Paulistas de Medicina e Cirurgia são outras revistas da época. Para mais revistas médicas publicadas neste período, consultar tese de doutoramento de Márcia Regina Barros da Silva, 2003 (pp. 249-250).
} 
Ribas e Dr. Oscar Lisboa, e professores como Linneu Silva, Eduardo Rabello e Antonio Austregésilo. Era um discurso médico 'pomposo', com os seguintes dizeres:

É assim que o encontramos exercendo cargos, desempenhando tarefas, ocupando posições extranhas á medicina, que sómente são confiadas a homens superiores. Si fóra da esphera para a qual elle preparou o seu espirito, e o seu corpo - elle desempenha-se galhardamente da sua incumbencia, porque não esperar que elle dentro de sua esphera, faça tanto senão mais?

Que os seus serviços são apreciados e os seus esforços galardoados, vemos na Inglaterra tantos medicos elevados á mais alta escala social egualando-os a esses que nasceram envoltos na purpura da realeza (Ellis, 1899, p. 91).

Nestes periódicos, os médicos combatiam as atividades de terapeutas populares, pedindo auxílio para as autoridades governamentais:

...a sentença de talentoso magistrado que proclamou recentemente
constitucional e legal a liberdade profissional applicada á medicina,
reconhecendo em um negro curandeiro e boçal o direito e a capacidade para
exerce-la, não póde pretender outra significação senão a do signal de uma
ameaça de invasão e avassalamento dos tribunaes brazileiros... (Rodrigues, 1899, p. 170).

Com efeito, outras revistas científicas e alguns documentos oficiais que circulavam no meio médico publicavam, para informar a seus colegas de profissão e às autoridades governamentais, denúncias e outros problemas relativos às práticas de charlatães na medicina. Por exemplo, Jose Oscar Ramos, o “...grande botanico...” (p. 53), exercia ilegalmente a medicina. Também não possuía registro de título na Diretoria do Serviço Sanitário de Jardinópolis, interior de São Paulo:

...o ousado charlatão 'cura' molestias incuraveis, o que consta de 'attestados' por elle mencionados no mesmo prospecto... (Correspondência com diversas autoridades, 1929, p. 53). 
A falta de inspeção das atividades de indivíduos que se passavam por médicos passou a ter maior controle após a publicação do artigo 15 contido no decreto estadual $n$. 3.876 de 1925: tal inspeção ficava a cargo do inspetor-chefe, responsável por:

...corresponder-se directamente com as autoridades policiaes e municipaes, no interesse do servico; ...cumprir e fazer cumprir as leis, os regulamentos e o regimento interno. (Lobo, 1925, p. 474).

A despeito de todas as rupturas nos caminhos das profissões de saúde, a legislação sanitária no estado em 1892 acabou por iniciar um processo de 'engrandecimento' da profissão médica, que vemos ainda nos dias de hoje ${ }^{65}$. Médicos, assim, começavam a se destacar na medicina, e a Primeira República paulista terminou com um discurso médico mais ou menos com esse tom:

É raro, rarissimo, o recanto de nosso Estado, por mais afastado dos grandes centros, em que se não encontre um ou varios medicos competentes, verdadeiros heróes, apostolos da profissão, que luctam, que se esfalfam, que reduzem ou sacrificam a propria vida, lidando com uma população analphabeta, incapaz de comprehendel-os.

Está indelevelmente gravado na nossa memoria, um episodio que attesta plenamente, não haver exaggero, quando nos referimos ao sacrificio da propria vida.

Ha quatro ou cinco annos, n'uma cidade sertaneja, um jovem medico foi chamado a deshoras, para attender a uma doente que diziam estar muito mal. Depois de algumas leguas de desconfortada viagem, indicam-lhe o logar em que se achava a doente.

Numa choupana primitiva, uma mulher contorcia-se em convulsões eclampticas. O profissional faz uma sangria. O caso era gravissimo e a doente vem a fallecer logo depois. $O$ marido attribuindo ao medico o exito lethal, assassina-o covardemente com uma bala trahiçoeira...(Rocha, 1928, p. 38-39).

\footnotetext{
${ }^{65}$ A discussão sobre o Projeto de Lei 7703/2006 entrou novamente na agenda governamental e dos profissionais de saúde, com sua aprovação pela Câmara dos Deputados em 22 de outubro de 2009. O objetivo é o de regulamentar a medicina, dando atribuições exclusivas aos médicos: teoricamente, tais atribuições esbarrariam nas funções de outros profissionais de saúde, como biólogos, biomédicos, dentistas, farmacêuticos, fisioterapeutas, fonoaudiólogos, enfermeiros, assistentes sociais, nutricionistas, profissionais de educação física, psicólogos, terapeuta ocupacionais e técnicos e tecnólogos de radiologia. O motivo alegado pelos representantes do projeto de lei é o de acabar com as "charlatanices" contemporâneas, como por exemplo, a prática da profissão de farmácia executada por um balconista, os massagistas sendo confundidos com os fisioterapeutas, e assim por diante. Para leitura do projeto, consultar: Ato Médico PL7703/2006.
} 


\subsection{Na Inglaterra}

Assim como em São Paulo, os médicos ingleses também foram ganhando um espaço importante ao longo de suas trajetórias profissionais. Pelos mesmos motivos que os médicos paulistas, foram ativos na sociedade inglesa para combater charlatães e suas práticas populares. Também ganharam cargos de destaque em postos que não eram diretamente relacionados às suas atribuições técnicas profissionais. Como em São Paulo, os médicos da Inglaterra atuaram nas reformas legislativas da saúde pública.

Porém, uma diferença importante com nossos médicos paulistas foi o fato de médicos ingleses serem tão fundamentais na sociedade da Inglaterra do século XIX quanto os outros profissionais de saúde, e a reforma médica inglesa mostrou a importância e o envolvimento dos médicos junto de cirurgiões, químicos e droguistas, apotecários. De maneira geral, os médicos da Inglaterra do século XIX não mostraram grandes 'confrontos' com estes profissionais, como vimos os embates, ora entre cirurgiões e químicos e droguistas, ora entre apotecários e cirurgiões. Os médicos ingleses incomodavam-se, na verdade, com seus rivais, os 'médicos do povo'. É a partir desse ponto que vamos iniciar nossa caminhada para compreender como os médicos da Inglaterra influenciaram na terapia popular, o que fizeram para ganhar seu espaço e como contribuíram para controlar o exercício dos terapeutas populares, bem como das suas artes de cura.

Esses médicos participaram tanto da reforma médica como da sanitária, exercendo influência nos cuidados médicos populares dos quais a sociedade inglesa fazia uso. Ao lado de cirurgiões e apotecários, foram conquistando um espaço dentro da saúde pública da Inglaterra, ganhando legitimidade parlamentar e popular, em paralelo às suas práticas de cura popular, e ao combate destas executadas por outros indivíduos.

Mas não somente homens sem um diploma em medicina, como alguns próprios médicos populares, utilizavam-se de técnicas bastante comuns e caseiras naquele período, como as purgações. Bucham (1805) ressaltou, por exemplo, que quando o paciente estivesse febril, eram necessárias evacuações, que seriam conseguidas pelo emprego de substâncias como o ruibarbo e o creme de tártaro: introduzidos no organismo por sangramento de alguma parte do corpo, em doses pequenas por várias semanas, ou mesmo por vários meses, o indivíduo ficaria puro 
das doenças (p. 402). Caso tal método não funcionasse, o manual de saúde, escrito por um médico, indicava outra solução: o uso de opiáceos e outros medicamentos antiespasmódicos em substituição à diarréia, aos vômitos e os aos purgantes. Especialmente o láudano líquido misturado ao chá, a cada oito ou dez horas, até os sintomas cessarem. Finalizava a publicação com os dizeres: "Ease, cheerfulness, and tranquillity of mind are here of the greatest importance." (p. 297).

Tais técnicas, usadas não apenas por médicos como também por cirurgiões, foram buscadas pela falta de médicos ou pela falta de conhecimento das funções destes profissionais, conforme já apontamos. Muito dessa falta de conhecimento acerca das atribuições médicas na sociedade ligava-se à escassez de recursos financeiros na saúde pública inglesa. Segundo relatório apresentado por Edwin Chadwick (1829) para as autoridades responsáveis, havia uma lacuna no montante financeiro voltado para o pagamento de médicos: espelhava-se nas taxas elevadas de mortalidade e morbidade, ocasionadas pelo aumento na carência de profissionais médicos. Howard (1847), apoderando-se do discurso do Visconde Morpeth, argumentou que

No such mortality has been witnessed in Birmingham for many years. The deaths in 1845 were 694; in 1846 they amounted to 1,627. (p. 30).

Propôs um 'Grupo de Saúde e Trabalhos Públicos' para controlar tais mortes. Neste grupo, uma das figuras mais importantes deveria ser um oficial médico responsável pelo controle das doenças, especificamente das doenças epidêmicas, onde seriam nomeados em cada distrito, e chamados de 'oficiais da saúde'.

Com efeito, a falta de saneamento das famílias pobres piorava os quadros de doenças. Arthur Helps (1854) discutiu a implementação do 'Fundo de Saúde de Londres'. A preocupação voltou-se principalmente para as epidemias de cólera no verão, alegando que as famílias pobres de Londres eram tão insuficientemente alojadas que, em geral, havia apenas um quarto para cada família. Acrescentou que todos os quesitos humanos para se levar uma vida decente e confortável eram inadequados, a limpeza não existia, a educação necessária comum passava a ser uma exigência de luxo. Finalizava o discurso argumentando que até mesmo os animais do campo viviam em melhores condições que tais famílias (1854, p. 4). 
Neste contexto, a reforma sanitária traria modificações para estas famílias, em paralelo à reforma médica, que tentava combater a medicina não-convencional, principalmente pelo exercício de charlatães, curandeiros e aqueles profissionais de saúde que lutavam por um espaço na área de saúde: os químicos e droguistas, e os apotecários. A fundação da Associação Cirúrgica \& Médica Provincial em 1832 (futura Associação Médica Britânica) demonstrou preocupação no combate às práticas de muitos charlatães. Horner (1995) enfatizou que existiam, pelo menos, 21 maneiras de algum indivíduo ser autorizado a praticar a medicina. Argumentou ainda que ocorria uma mistura da medicina, dos sistemas de saúde, de convicções religiosas e de ações políticas, todas as quais poderiam criar um ambiente propício para a mudança.

Contribuiu para o combate dessa medicina não-convencional o crescimento de diversos movimentos médicos de auto-ajuda, que ganharam força na primeira metade do século XIX. O combate ao alcoolismo, aos exageros alimentares e a outras doenças foram alguns exemplos incluídos na lista (Shryock and Harrison citado por McLaren, 1977). Buchan (1805) ressaltou que o essencial para a cura de uma doença era a atenção ao estado mental da pessoa. Se um paciente estivesse fragilizado fisicamente, sua mente também o estaria, e que era preciso 'distraí-la' por meio de música, estórias, recreações e outras formas de entretenimento (p. 402).

Desta forma, o trabalho com as condições psicológicas dos enfermos fazia parte destes movimentos de auto-ajuda do início do século XIX. Por exemplo, o álcool era permitido somente em casos de terapia médica, era condenado se utilizado com propósitos de lazer. Médicos, que também participavam destes movimentos, divulgavam notas sem esclarecimentos claros sobre os efeitos do álcool nas doenças para a população. Desejavam muito mais fazer um controle mental sobre o uso dessa substância, e o que ela acarretaria para o usuário. Exemplificaram com os casos de cólera, argumentando que se uma pessoa fizesse o uso do álcool assiduamente, então seria a primeira a pegar tal doença, e teria muitas dificuldades em curá-la:

We, the undersigned, at the request of Leeds Temperance Society, beg to state our strong Opinions, that those who are addicted to the use of Spirits, and especially those who Constitutions are already impaired by the use of fermented liquors of all kinds, will be the first to suffer from Cholera, and the last to escape its Effects. $R$. W. D. Thorp, M. D.; James Williamson, M. D.; A. Hunter, M. D.; Thomas Chorley, Willian Hey, C. Turner Thackrah, William Hey, Jun.; R. C. Battye, G. Bulmer, Francis Sharpe. (Higginbottom, 1843, p. 5, grifos nossos). 
Médicos ingleses objetivavam também combater tais práticas incentivadas pelo exercício de charlatães. O Colégio Londrino de Médicos divulgou processos parlamentares de indivíduos exercendo a medicina sem uma licença:

...the following extract from a return made by the College to Parliament in 1834 will show: - "Dec. 22, 1809. - An action was commenced against Dr. Dick, for practising without a licence, to which the defendant appeared, and after having obtained time to plead, suffered judgment by default, and paid the penalty, 50l., with the taxed costs. (Chapman, 1858, p. 497, grifos nossos).

Tal preocupação se exacerbava à medida que a prática de quackery na Inglaterra ganhava forças com o crescimento de material publicitário, como panfletos e folhetins, ocasionado pelo desenvolvimento urbano-industrial. A literatura destes charlatães era buscada até mesmo por pessoas que necessitavam de alguma instrução em temas como a procriação, desejando informações, por exemplo, sobre o aparelho reprodutivo. Segundo a visão dos médicos, o objetivo maior destes charlatães não era de 'ensinar' a medicina reprodutiva para a população, e sim de 'aterrorizar' a população masculina sobre as consequências dos excessos sexuais: tal excesso traria doenças, que necessitariam de medicações e restaurativos, aumentando os gastos financeiros ordinários. De acordo ainda com estes médicos, estes terapeutas do povo tentavam atrelar valores morais à assuntos delicados da vida humana, que eram pouco discutidos abertamente. Faziam uma 'pressão psicológica' em cima da população, de forma a coibi-la, a amedrontá-la sobre assuntos nos quais não compreendiam muito claramente (Chapman, 1858).

$\mathrm{Na}$ realidade, todas estas ações de médicos ingleses, tanto na reforma médica como na sanitária, objetivavam um ponto: de serem substituídos por estes charlatães, de ganharem espaço na saúde pública da Inglaterra. O século XIX foi palco de tantas investidas médicas que visavam a atenção da população e das autoridades políticas sobre os benefícios profissionais que eles proporcionavam. Alguns autores colocavam estes médicos como os únicos homens capazes de curar doenças, cuidar da saúde do povo: homens superiores, divinos, quase como 'deuses'. Havia uma aproximação da religião e destes doutores. Ao mesmo tempo em que combatiam a prática religiosa como forma de tratamento médico, consideravam-se, e eram considerados por alguns colegas, como personalidades de saúde ‘divinos' (Brown, 1861). 
De fato, uma revista popular publicou um sermão para os trabalhadores, explicando a importância dos médicos na saúde. No discurso, foi enfatizado que a população deveria confiar no trabalho de tais profissionais, e rejeitar as práticas de charlatanismo. Palavras como 'obedecer' e 'dever' apareceram na publicação:

One person I would earnestly warn you against, and that is the Quack

Doctor. If the real Doctor is a sort of God of healing, or rather our God's cobbler for the body, the Quack is the devil for the body, or rather the devil's servant against the body. And like his father he is a great liar and cheat. He offers you what he cannot give. Whenever you see a medicine that cures everything, be sure it cures nothing, and remember, it may kill. (Brown, 1861, p. 30-32, grifos nossos).

Nestas condições, a Inglaterra mostrou esta importância 'diferenciada' destes profissionais na sociedade inglesa especialmente quando se realçou sua trajetória ao longo do século XIX dentro das instituições de saúde, e o papel que exerciam dentro delas. Um médico clínico geral que trabalhou em um dispensário criado na cidade inglesa Brighton escreveu uma carta para os dirigentes da instituição, frisando o direito de um paciente pobre de receber auxílio público de saúde por meio de médicos inseridos em um departamento de ciência médica com profundos conhecimentos em administração geral; somados a isso, os médicos deveriam possuir uma “...high reputation for their skill in the treatment of particular classes of disease." (A Letter to the Governors of the Brighton Dispensary, 1843, p. 9).

Tais instituições foram criadas para dar assistência à esta população carente, encorajando-a a buscar este auxílio, pemitindo-a que cuidasse de si mesma através destes dispensários de saúde, uma vez que eram consideradas instituições de caridade (An Essay on Dispensaries, 1838). Outras cidades como Liverpool, Londres e Manchester também as criaram. A primeira reunião para discutir sobre melhorias na saúde através da criação destas casas aconteceu em 1832 (Irvine, 1933).

Os médicos ingleses, neste contexto, ganhavam prestígio dentro destas instituições. Os próprios dirigentes dessas casas davam preferência para o trabalho destes profissionais, em detrimento do trabalho de cirurgiões, por exemplo: preferiam as práticas 'técnicas' dos médicos do que a medicina 'familiar' a qual o cirurgião fazia uso na maior parte dos casos (A Letter to the Governors of the Brighton 
Dispensary, 1843). Conforme aponta um próprio cirurgião, a profissão médica crescia dentro da sociedade inglesa, e sua trajetória foi marcada por privilégios em relação às outras profissões:

...- the only difference being, that by paying thirty or forty pounds he can be a physician; if he pays about twenty pounds he can be a surgeon, and if six or ten pounds he can be an apothecary. (Simpson, 1847, p. 5).

Estes privilégios para a profissão médica começavam a se tornar cada vez mais evidentes, dando força política e moral para que estes profissionais continuassem a seguir este caminho. Isso traria consequências para aqueles charlatães que exerciam suas artes de cura na sociedade do século XIX. Se não caíam nas mãos do controle parlamentar, então ao menos se enfraqueciam.

Aos médicos era também facultado o dever de saber muito bem os ofícios da medicina. Neste sentido, sua classe também foi fortalecida pela elevação de seus conhecimentos médicos, por meio do provimento de maior educação técnica em medicina. Isto foi se consolidando à medida que crescia o desenvolvimento das escolas médicas. Com efeito, tal educação para futuros médicos foi destacada em diversas reuniões do comitê de educação médica na Inglaterra. O desenvolvimento das escolas de medicina, especialmente em Cambridge e Oxford, cujas datas de fundação são anteriores a 1540, foi um fator que contribuiu para alcançar tal objetivo. Enfatizava-se que o melhor caminho para o desenvolvimento médico era o estabelecimento de escolas na metrópole do país (Reports from select committees, 1834, p. 32).

Somadas às escolas na Inglaterra, a Universidade de Edimburgo, na Escócia, fundada em 1726, possuía uma das mais prestigiadas escolas de medicina da GrãBretanha no início do século XVIII (Lobban, 1980), que influenciou sobremaneira nas escolas médicas inglesas. Embora alguns críticos argumentassem que as disciplinas ensinadas nesta escola não tratassem dos problemas de saúde atrelados ao escasso saneamento urbano do período (Our Schools of Medicine, 1858), a escola de medicina de Edimburgo foi tão importante quanto às de Oxford e de Cambridge para o desenvolvimento da profissão médica ao longo do século XIX.

O conhecimento ensinado para os futuros médicos envolvia não somente a bagagem técnica médica como também alguns aspectos morais relacionados à 
medicina. Segundo o comitê responsável, isto aumentaria a confiança do público nos serviços médicos:

You attribute this, in part at least, to the discipline of the English Universities; to the effect of such discipline in improving the conduct of the persons there educated, which raises them in public estimation... (Reports from select committees, 1834 , p. 36 , grifos nossos).

De acordo com Porter (1997), a educação médica não era uniforme. Nõ havia um sistema de controle sobre o que era ensinado nas escolas. Argumentou que o sucesso do ensino dependia da capacidade de satisfazer o público.

Somado a isso, as autoridades que atuavam na reforma médica almejavam a separação do sistema educacional que formava os apotecários e os médicos (Remarks on medical reform, 1843). Antes do Ato dos Apotecários de 1815, médicos e apotecários tiveram estreita relação, com estes últimos trabalhando como assistentes dos primeiros:

By this act the faculty of medicine was vested in one body of practitioners, who practised Medicine, Surgery, and Pharmacy. The Physicians' assistants were styled Apothecaries, and they, gradually acquiring information respecting the properties of drugs, began to transact business on their own account. (Bell, 1843 , p. 4, grifos nossos).

De fato, houve um rearranjo no sistema educacional dos médicos no século XIX. Se considerarmos seu conhecimento na Inglaterra do período medieval, por exemplo, a situação estava em transformação: naquela época, o conhecimento médico era basicamente concentrado na parte prática da medicina, ficando a teoria médica restrita aos homens religiosos. Em geral, estes religiosos possuíam o acesso ao conhecimento médico por meio dos manuscritos antigos. Com o alargamento da população urbana, a especialização médica foi ganhando espaço, pedindo o cuidado médico baseado na diferenciação gradual do atendente comum para o barbeirocirurgião; do vendedor de especiarias para o apotecário. Neste contexto, o médico da cidade ganhou as funções de diagnóstico, prescrição e prognóstico médicos, enquanto que as atividades manuais, confusas, dispendiosas em tempo, de cortar, sangrar, 
costurar e dispensar ficaram confinadas aos subservientes barbeiro-cirurgiões e apotecários (Bell, 1843, p. 69-70).

Nestas condições, as autoridades governamentais deveriam ser mais 'exigentes' com médicos, já que possuíam mais conhecimentos técnicos. Mas as exigências não se circunscreviam à educação médica: era preciso aumentar o rigor legal para a profissão médica. Rumsey (2001), discutindo o avanço da educação médica, apontou que a punição legal, em caso de 'infrações', deveria ocorrer somente para profissionais com qualificação médica, como eram taxados os médicos; já para charlatães e outros terapeutas populares, a punição legal não deveria ocorrer. No primeiro grupo, o autor incluiu homeopatas e outras profissões relacionadas; no último, “...smiths, weavers, and women...” (p. 63). Seu argumento sustentava-se no fato do segundo grupo não ser culpado pela própria ignorância, que o levava a exercer o charlatanismo. Caso estes indivíduos cometessem quaisquer "barbaridades" nas práticas de cura, então não deveriam ser punidos.

Porém, com a determinação dos Atos Médicos, os rumos dos profissionais ingleses foram se direcionando para o benefício de suas profissões, que mudariam as ações de cura populares e o olhar da população sobre o médico. O Ato Médico Benjamin Hawes em 1841 aconteceu para defender as práticas dos médicos clínicos gerais, ameaçados pelas ações de medicina popular praticada pelos químicos e droguistas (Burt, 1999). Mas teve seu reforço com o Ato Médico de 1858, que foi estabelecido principalmente para esclarecer quais eram as funções técnicas de medicina destes profissionais. Por exemplo, a idéia de comércio, originada através das práticas de apotecários e cirurgiões, foi marcadamente abolida com o passar deste Ato: não eram considerados mais 'comerciantes' de medicamentos e de conselhos médicos frente à lei (Cope, 1959).

Ademais, este Ato foi consequência não somente do Ato de 1841, como também da Emenda da Lei dos Pobres de 1834 e da Ordem Médica Geral de 1842. No conteúdo desta última, havia a dupla qualificação dos médicos em medicina e cirurgia. Na verdade, este Ato de 1858 pretendia anular os interesses divididos dos Colégios Royais, na tentativa de unificar as classes médicas. No entanto, segundo Varlaam $^{66}$ (1977), foi muito difícil de atingir este objetivo pois médicos, cirurgiões e

\footnotetext{
${ }^{66} \mathrm{O}$ autor menciona, em adição, que o Ato Médico de 1886 se passou para dar qualificação completa nos registros em medicina, cirurgia e emfermagem. Também menciona que não houve outro Ato Médico até 1950.
} 
apotecários desejavam a manutenção dessa divisão: cada classe queria exclusividade em suas atribuições técnicas. Cada uma destas classes, não conseguindo isto, acabaram indo na direção do Ato Médico de $1858^{67}$. Este ato reforçava a importância dessa união profissional na elevação de seus conhecimentos técnicos, por meio da educação em cursos médicos:

declared it to be expedient that persons requiring qualified from unqualified practitioners, called into being the General Council of Medical Education and Registration of the United Kingdom, and entrusted to it the task of making and keeping "The Medical Register" and of publishing "The British Pharmacopoeia." The Act conferred wide powers upon the Council in order that it might maintain, by the supervision of courses of study and examinations, the standard of professional knowledge of those about to enter the profession; and, by the power of erasure from the Register, the standard of professional conduct of registered practitioners.

(Harper, 1912, p. 3, grifos nossos).

Este ato influenciou não apenas a área de saúde, como também outros campos, como o político: com a determinação do Ato Médico de 1858, mudou-se o centro de negociações de Londres para toda a Inglaterra e para o País de Gales. Conforme aponta a Associação Médica Britânica, foi o primeiro reconhecimento oficial da existência de um grande grupo de práticos médicos de importância para o estado, com o registro dos membros profissionais, a preparação de uma farmacopéia nacional e a formação de um Conselho Médico Geral (Annals of the Royal College of Physicians, 1991).

Segundo Parry \& Parry (1976), o Ato Médico de 1858 elevou não somente médicos a uma posição privilegiada, mas também cirurgiões e apotecários: foi a principal "marca registrada" do crescimento do apotecário e do cirurgião, que os tiraram daquela condição inferior de homens comerciantes e artesãos. Transformaram-se em uma classe médica unificada com o status elevado de médicos.

\footnotetext{
${ }^{67}$ As duas emendas no Ato Médico de 1858 discorreram, principalmente, sobre outras mudanças no escopo educacional. Para leitura sobre a questão, consultar:

Great Britain, Parliament, House of Commons, Select Committee on the Medical Act (1858) Amendment (No. 3) Bill. Special report from the Select Committee on the Medical Act (1858) Amendment (No. 3) Bill [Lords]: together with the proceedings of the Committee, minutes of evidence, and appendix. London : H.M.S.O., 1879; Great Britain, Parliament, House of Commons. Select Committee on the Medical Act (1858) Amendment (No. 3) Bill. Special report from the Select Committee on the Medical Act (1858) Amendment (No. 3) Bill: together with the proceedings of the Committee, minutes of evidence, and appendix. London: H.M.S.O., 1880.
} 
De acordo com estes autores, iniciava-se a formação da corporação médica inglesa. Legalmente, o apotecário tornou-se o médico clínico geral após a criação deste ato. E os cirurgiões, em médicos especialistas. Waddington (1984) aponta que antes deste ato, não havia conhecimento ou registro sobre o clínico geral.

Gamgee (1877), membro da Associação Médica Britânica, analisou o papel dos clínicos gerais na sociedade. Em geral criticava-os, especialmente por mostrarem seus interesses pessoais sobrepujando as necessidades públicas: por exemplo, quando se encontravam frente às casas de caridade, argumentou que era preciso conduzir uma investigação dentro destas instituições por causa de seus abusos profissionais, que em geral se aproveitavam do fato destas instituições serem gratuitas para tirar proveito. Enfatizava-se a diferença que existia entre as instituições beneficentes e as 'interesseiras'.

Os abusos tornavam-se mais evidentes, à medida que o objetivo destas instituições eram três: o primeiro, de que o mantenedor financeiro das casas de caridade confiavam no exercício dos profissionais, que se circuncreveriam a usar a verba somente para tal objeto; o segundo, de que os clínicos gerais ofereceriam seus trabalhos sem remuneração; o terceiro, de que estes profissionais trabalhariam de acordo com sua posição financeira na sociedade, adequando-a àqueles que procuravam seu auxílio médico (Gamgee, 1877).

Robert Rentoul (1891) discutiu o problema destas caridades. Considerou que os interesses privados de algumas classes da sociedade impediam seu desenvolvimento conforme as propostas iniciais. Destacou que os médicos clínicos gerais utilizavam as instituições de caridade com o propósito de

...self-advertising, and to such an extent that it has lately been asked: 'Do our Medical Charities exist for the benefit of the doctors, or for the poor?' Is not Medical 'Charity' now almost a trade? (p. $\mathrm{x}$, grifos nossos).

Segundo S. Hogarth (2007), o 'poder' dos médicos nestas instituições solapou as decisões individuais dos pacientes. Antes dos Atos Médicos, a população inglesa possuía a possibilidade de escolher o tratamento médico mais adequado para si: praticavam as medicinas caseira, religiosa e folclórica. As regras destas instituições modificaram a relação entre médico e paciente, trazendo o enfraquecimento destas 
instituições de caridade. A terapia popular, entretanto, diminuiu com o desenvolvimento destes locais e também com o progresso médico.

Em contrapartida, Porter (1997) atenta que a reforma médica do século XIX na Grã-Bretanha não atingiu seu objetivo. Apesar da existência das três corporações (médicos, cirurgiões e apotecários), muito ainda era necessário para melhorar os problemas de saúde. Apesar, ademais, das considerações positivas de J. A. Davenport (1887), um inspetor do serviço sanitário, sobre o exercício dos oficiais médicos na melhora do quadro de epidemias no século XIX (p. 76), Porter (1997) argumenta que a população desejava tomar suas próprias decisões no cuidado à saúde. A existência dos métodos alternativos de cura, como a homeopatia e a hidropatia, eram algumas práticas que se confrontavam com a trajetória da ciência médica inglesa:

Alternative medicine's preoccupations highligh the ambiguities in nineteenthcentury medicine. Its new scientific and professional movements generated counter-trends - a populist, anti-elitist backlash. While people wanted their diseases to be cured, they were also seeking far more from medicine: explanations of their troubles, a sense of wholeness, a key to the meaning of life. Craving reassurance from physicians, democratic generations also, paradoxically, wanted to take health into their own hands. (p. 396, grifos nossos).

\subsection{Amarrando as funç̃̃es de médicos na Inglaterra e em São Paulo}

O exercício da arte médica foi conduzido por profissionais médicos paulistas e ingleses que tentavam trabalhar em benefício da saúde pública, ao lado de seus próprios anseios profissionais. Atuaram em conjunto com os terapeutas do povo, tentando influenciar as autoridades políticas das respectivas localidades para frear as atividades de cura populares. Trabalharam, por exemplo, para sair daquele uso dos manuais de higiene, tão comuns às respectivas épocas, bem como do exercício de charlatães e curandeiros nas práticas médicas. Evidenciamos, aliás, não somente uma semelhança nas atitudes dos médicos de ambos os locais nas lutas contra estas práticas populares, como também uma pequena conexão entre Inglaterra e São Paulo: um exemplo foi a substituição do manual de William Buchan, tão consultado não somente em São Paulo como em todo o Brasil, pelo manual de Pedro Luiz Napoleão Chernoviz, conhecido como 'Chernoviz'. Guimarães (2005) credita a alguns historiadores o fato do Domestic Medicine ter sido o primeiro manual a ser utilizado aqui, durante todo o século XVIII. 
Um traço bastante comum entre as duas sociedades foi o combate às práticas de charlatães durante todos os dois períodos de análise considerados, especialmente por causa das epidemias que pioravam a saúde das duas populações. Médicos, neste sentido, tentaram ganhar 'crédito' na medicina, uma vez que seu trabalho era pouco conhecido ou mesmo pouco confiável. Por meio de sua influência frente às autoridades governamentais, agiam de forma a mudar sua posição dentro das sociedades inglesa e paulista. Assim, usaram das necessidades de saúde das populações respectivas para crescer dentro de suas próprias profissões. É possível que tenham sido as práticas de terapia popular que influenciaram médicos a tomarem iniciativas para que ocorressem as reformulações na saúde, e não que tais profissionais objetivassem, primeiramente, o combate às artes de cura. A despeito destes interesses pessoais, os médicos contribuíram para que os avanços na medicina trouxessem melhorias na saúde pública dos dois locais. Nestas condições, fazem sentido as reformas na saúde, tanto na Inglaterra como em São Paulo. Na Inglaterra, a reforma sanitária andou em paralelo à reforma médica: foram duas iniciativas legais diferentes, mas que se complementavam, na medida em que os médicos passaram a ser atores importantes frente às necessidades de mudanças sanitárias. Segundo Holloway (1991) aponta, a reforma médica inglesa, iniciada com o Ato dos Apotecários em 1815, começou por necessidade de se estabelecer normas para o exercício das funções de cada profissional de saúde do período. No caso, médicos, apotecários, cirurgiões, farmacêuticos e químicos e droguistas. A tabela ${ }^{68}$ seguinte resume estas profissões de saúde na Inglaterra, destacando os principais atributos de cada profissional:

Tabela 4. Resumo das profissões de saúde na Inglaterra - sécul os XVIII/XIX

\begin{tabular}{|l|l|l|l|}
\hline Profissionais & Principal período & Ato Médico & Função \\
\hline
\end{tabular}

\footnotetext{
${ }^{68}$ As datas foram baseadas nas principais decisões governamentais e de autoridades de saúde, levando em consideração o período até 1858; os limites temporais não significam a emergência de cada profissão, ou o único período em que atuaram estes profissionais na saúde inglesa. Cada um deles praticou sua respectiva função em momentos anteriores, bem como em momentos posteriores a 1858.
} 


\begin{tabular}{|c|l|l|l|}
\hline & de atividade & & \\
\hline Químicos e & $1780^{69}-1852$ & $\begin{array}{l}\text {-Ato dos } \\
\text { Apotecários de } \\
1815 \\
- \text { Ato } \\
\text { Farmacêutico de } \\
1852\end{array}$ & $\begin{array}{l}\text { Conselheiros } \\
\text { médicos e } \\
\text { manipuladores } \\
\text { de fórmulas }\end{array}$ \\
\hline Cirurgiões & $1745^{70}-1858^{71}$ & $\begin{array}{l}\text { Ato Médico de de } \\
1858\end{array}$ & $\begin{array}{l}\text { Conselheiros } \\
\text { médicos e } \\
\text { manipuladores } \\
\text { de fórmulas }\end{array}$ \\
\hline Apotecários & $1815-1858$ & $\begin{array}{l}\text { Ato dos } \\
\text { Apotecários de } \\
1815\end{array}$ & $\begin{array}{l}\text { Conselheiros } \\
\text { médicos }\end{array}$ \\
\hline Farmacêuticos & $1841^{72}-1858^{73}$ & $\begin{array}{l}\text { Ato Farmacêutico } \\
\text { de 1852 }\end{array}$ & $\begin{array}{l}\text { Manipuladores } \\
\text { de fórmulas }\end{array}$ \\
\hline Médicos & $1815-1858$ & $\begin{array}{l}\text { Ato Médico de de } \\
1858\end{array}$ & $\begin{array}{l}\text { Conselheiros } \\
\text { médicos }\end{array}$ \\
\hline
\end{tabular}

A partir de 1830, quando do Ato da Reforma de 1832, médicos encontravamse envolvidos nas modificações sanitárias inglesas, ao passo que em São Paulo, não somente médicos, mas também farmacêuticos, sofreram e pediram novas regulamentações para o novo contexto do período, representado pela reforma sanitária de 1892.

Nestas reformas, tanto os médicos paulistas como os ingleses foram personalidades importantes que atuaram não somente com seus atributos médicos, mas também participaram de atividades de decisão política. Foram médicos administradores, médicos inspetores, médicos-chefe. Agiam, algumas vezes, em conjunto com autoridades governamentais, influenciando na política de cada local; seu percurso permitiu um ganho de autoridade dentro da saúde pública das duas regiões.

\footnotetext{
${ }^{69}$ A partir desta data, aconteceram novos tipos de comércio, e os químicos e droguistas, em conjunto com comerciantes comuns, foram alguns dos profissionais envolvidos.

${ }^{70}$ Este ano corresponde à criação da Companhia de Cirurgiões.

${ }^{71} \mathrm{O}$ exame para se tornar um membro da Companhia Royal de Cirurgiões incluía exames orais no século XVIII. Em 1843, uma nova e mais nobre qualificação - ser membro direto dessa Companhia, sem a necessidade de exames. Informação coletada em 27/03/2009 da exposição permanente do Museu Hunterian no Colégio Royal de Cirurgiões.

${ }^{72}$ Esta data corresponde à criação da Sociedade Royal Farmacêutica da Grã-Bretanha.

${ }^{73} \mathrm{O}$ período após o Ato Médico de 1858 foi também relevante para a farmácia, especialmente com a determinação do Ato Farmacêutico de 1868: "After the Pharmacy Act of 1868, only pharmacists registered with the young Pharmaceutical Society could sell restricted medical "poisons". These included morphine and strychnine, exciting discoveries in the 1830s. Pharmacists still made many medicines on site. However, in 1900, pharmacists sold six times as many ready-made proprietary medicines as in 1850." Informação coletada em 27/03/2009 do Museu da Sociedade Royal Farmacêutica da Grã-Bretanha.
} 
Uma diferença nas profissões de médico inglesa e paulista foi evidenciada pela trajetória de formação deste profissional. O médico aqui já era o profissional de saúde responsável pelo diagnóstico médico, independente das novas determinações contidas na nova legislação sanitária de 1892; já os embates na Inglaterra entre cirurgiões, apotecários e médicos ainda estavam por determinar as funções hoje conhecidas dos médicos naquele país. Somente após o estabelecimento do Ato Médico de 1858 é que a profissão do médico inglês começou a ganhar forma, transformando-os, de apotecários e cirurgiões, nos médicos de hoje, clínicos gerais ou especialistas, respectivamente.

Notamos também uma proximidade no trabalho de médicos com farmacêuticos em São Paulo, o que não aconteceu na Inglaterra: neste país, evidenciamos mais uma atuação parlamentar para regulamentar as profissões de médicos, cirurgiões e apotecários, com trabalho em conjunto de farmacêuticos e médicos ingleses de pouca expressividade. Sonnedecker (1986) aponta que esta 'confusão' nas profissões de saúde decorreu do fato da Inglaterra ser uma ilha e ter ‘demorado' a determinar as funções de farmacêutico e de médico já em momentos anteriores à Idade Média, como aconteceu em outros países europeus como França e Itália. Não somente os ingleses como toda a Grã-Bretanha viviam à base de comerciantes de drogas e especiarias que iam e vinham das ilhas britânicas, circunscrevendo a medicina e a farmácia a um caráter popular. Em contrapartida, os ofícios de médico e de farmacêutico dialogavam entre si o tempo todo em outros países europeus. Isso retardou o processo de separação dos papéis daquele que diagnosticava doenças e daquele que fazia medicamentos oficialmente. $\mathrm{O}$ autor atenta ainda que a Inglaterra só teve a primeira escola de farmácia após 1841, data da criação da Sociedade Farmacêutica Britânica. Até este período, os químicos e os apotecários se misturavam nas funções de formular medicamentos.

Ao mesmo tempo, a legislação voltada para as atuações dos médicos paulistas nas indicações terapêuticas estava muito mais voltada para o seu envolvimento com a indústria farmacêutica do que na Inglaterra: as preocupações das autoridades inglesas giraram em torno especialmente da função dos profissionais de saúde controlando fórmulas de base artesanal (o que se chamou de medicamentos comerciais e patenteados, conforme já citado), em geral manipuladas por pessoas sem qualificação técnica. Os medicamentos industriais, que seguiam um livro de referência, estavam, em sua maioria, 'controlados' pela legislação. Isto é válido se considerarmos os vários 
Atos Públicos Gerais que se passaram desde o final do século XVIII que davam especificações especialmente para o comércio dessas drogas, segundo apontamentos no capítulo "Farmacêuticos em São Paulo e na Inglaterra".

Neste contexto, os médicos começavam a ganhar um espaço na saúde pública de São Paulo e da Inglaterra. Por exemplo, em São Paulo, tal espaço se formava com a publicação das primeiras revistas médicas no estado, conectadas com o primeiro congresso médico e com as sociedades médicas do final do século XIX. Os debates profissionais acabavam acontecendo muito dentro destes próprios ambientes, onde tudo que dizia respeito a insatisfações ou a satisfações na carreira médica, era abordado nas revistas, nos congressos ou nas sociedades médicas. Na Inglaterra, diferentemente, a maior parte das evidências encontradas de benefícios para os médicos ingleses voltaram-se para os discursos parlamentares e alguns atos públicos onde se publicavam discursos médicos, semelhante ao que observamos quando investigamos o percurso profissional dos farmacêuticos ingleses.

Conforme Lopes (2001) aponta, esta forma de poder que foi se consolidando no mundo médico de hoje decorreu, principalmente, do processo de profissionalização da medicina no século XIX, que levou ao estabelecimento do diagnóstico e da terapêutica médicos. Foucault (2006) atenta ainda que o estabelecimento da autoridade médica está relacionado ao nascimento do hospital no final do século XVIII. Tal autoridade teria substituído as ordens religiosas que cuidavam dos doentes, em paralelo aos seus domínios políticos. Com a transformação do sistema de poder dentro do hospital, o médico passa a dominar o cenário hospitalar, não somente curando doentes, como também se responsabilizando pela organização do estabelecimento. Torna-se o 'grande médico' (p. 110).

Uma última questão que ficou evidente em ambas as regiões foi a necessidade sentida pelos próprios profissionais e também pelas autoridades públicas, de que se deveria melhorar o ensino médico nas escolas. Na Inglaterra, desejava-se abolir a separação no ensino existente entre médicos, cirurgiões e apotecários, ao passo que no estado de São Paulo, alguns primeiros embates entre médicos e farmacêuticos pela criação de um ensino superior, pela melhora das disciplinas ministradas e das condições de instalação dos cursos. O desenvolvimento da farmacologia, da fisiologia e outros assuntos médicos contribuíram para elevar a bagagem técnica destes profissionais. Neste contexto, estas matérias permitiram o desenvolvimento das farmacopéias, que levaram a um aumento no rigor das prescrições médicas (Porter, 
1997). Entretanto, é muito difícil precisar em que momento exato a prescrição médica tenha surgido. É provável que tenha surgido com os aumentos nas preocupações sobre o ensino médico - era parte da formação profissional para que ele fosse um 'bom' médico.

Por fim, evidenciamos que a medicina popular, a despeito dos embates médicos para controlá-la, continuou em curso, e que muito disso aconteceu em decorrência do desejo da população inglesa em mantê-la, em decidir por seus métodos de tratamento; na população paulista, as lacunas na legislação que permitiam o exercício de terapeutas populares, os anúncios em meios de comunicação populares e o desenvolvimento inicial da indústria proporcionaram a escolha por meios de cura terapêutica à parte da trajetória de estabelecimento da profissão médica e de todos os seus papéis na saúde. 


\section{Conclusões}

A prática de quackery na Inglaterra acontecia ordinariamente até o Ato de 1815. Eram comuns as práticas dos conselhos médicos e o comércio de medicamentos, conduzidos por diversos indivíduos comuns que trabalharam como 'médicos', 'diagnosticando' doenças e fazendo fórmulas para salvar vidas. Com a determinação deste Ato, ela continuou a existir, mas um novo quadro na saúde inglesa começava a surgir. Com a atenção parlamentar e dos profissionais de saúde voltada para as mudanças legislativas na saúde, o charlatanismo na Inglaterra passou a ser observado de maneira mais atenta, e medidas de controle das práticas populares começaram a emergir por meio das novas regulamentações das profissões de saúde, analisadas aqui até 1858. Enquanto isso, o estado de São Paulo também estava sofrendo transformações em suas práticas populares de cura que, semelhantemente à Inglaterra, tornavam-se atos 'ilegais', passíveis de regulamentação. Isso foi reforçado pelas novas leis governamentais de 1892 para as profissões de saúde, e até 1930 foram consideradas neste estudo. Assim, grande parte das práticas de cura não-científicas passaram a ser alvo do governo paulista e dos profissionais de saúde envolvidos neste processo de mudança durante a Primeira República.

Nestas condições, as mudanças legislativas na saúde contribuíram para que os profissionais de saúde ganhassem um prestígio dentro de cada sociedade. Passavam, passo a passo, a ser reconhecidos como profissionais importantes na saúde pública inglesa e paulista, consolidando, aos poucos, suas funções técnicas na saúde. Médicos, garantindo suas funções de diagnose clínica, e farmacêuticos, seus atributos voltados para o uso de medicamentos. Isso mudou a atuação daqueles terapeutas populares que trabalhavam com 'conselhos médicos' e manipulação de fórmulas. Estes terapeutas tiveram suas atividades populares controladas, cada vez mais, quando cada nova regulamentação entrava em vigor.

As novas regulamentações na saúde para as profissões de médico e de farmacêutico estiveram conectadas a fatores indiretos como as doenças, a industrialização, as instituições filantrópicas, as mudanças no ensino em medicina e em farmácia, o desenvolvimento das ciências farmacêutica e médica, a taxação, o comércio, a manipulação e o uso de medicamentos. À medida que o caráter científico dessas profissões crescia, deslegitimava-se a arte de cura. Todos estes fatores acabaram funcionando como 'complementos' dos interessses profissionais e governamentais. A cada momento em que era estabelecido um novo decreto ou lei 
para as funções de médicos ou de farmacêuticos, ocorria um reflexo nas práticas de terapia popular. De maneira indireta, esta prática de cura foi ganhando um contorno diferente, com tendência a um aumento normativo da mesma.

Pelos discursos médicos e farmacêuticos analisados, percebemos que estes profissionais acabaram 'tomando carona' nas incertezas das artes de cura populares para conseguir seus poderes dentro de suas áreas de atuação: de dar diagnósticos, de operar, de prescrever medicamentos, de assistir ao doente quanto às terapias medicamentosas, nas duas sociedades estudadas. Foram jogos de poder o tempo todo se misturando ao que as populações precisavam. Tudo isso em conjunto criou possibilidades destes profissionais crescerem como corporação para se estabelecerem nas sociedades paulista e inglesa da época como um dos grupos de indivíduos mais influentes em questões políticas e sociais. As profissões de médico e de farmacêutico foram se consolidando não independentes entre si, mas como um misto de dependência do estabelecimento das outras profissões de saúde, entre embates e concordâncias, entre quedas e levantes, de um ou de outro profissional.

Assim, estes 'pedaços' que foram abordados aqui de maneira bastante abrangente, requisitam um tratamento mais detalhado, especialmente porque não há, até o presente momento, investigação suficiente destas lacunas encontradas na história das práticas de cura populares, tanto na Inglaterra como no estado de São Paulo. Para futuras investigações, eis uma boa agenda de pesquisa. 
9. Currículo Lattes 


\section{Anexos}

Anexo I - Selo de medicamentos utilizados durante o século XIX na Inglaterra

Anexo II - Pintura A Laudable Partnership or Souls \& Bodies cured without loss of Time

Anexo III - Pintura The Quack Doctors Confession on his Death Bed

Anexo IV - Propaganda de medicamento do Diario Popular 1892

Anexo V - Propaganda de estabelecimento de comércio de medicamentos do jornal $A$ Cidade 1905

Anexo VI - Propaganda de estabelecimento de comércio de medicamentos contida na Revista Pharmaceutica 1897

Anexo VII - Propaganda de medicamento contida na Revista de Medicina 1918 


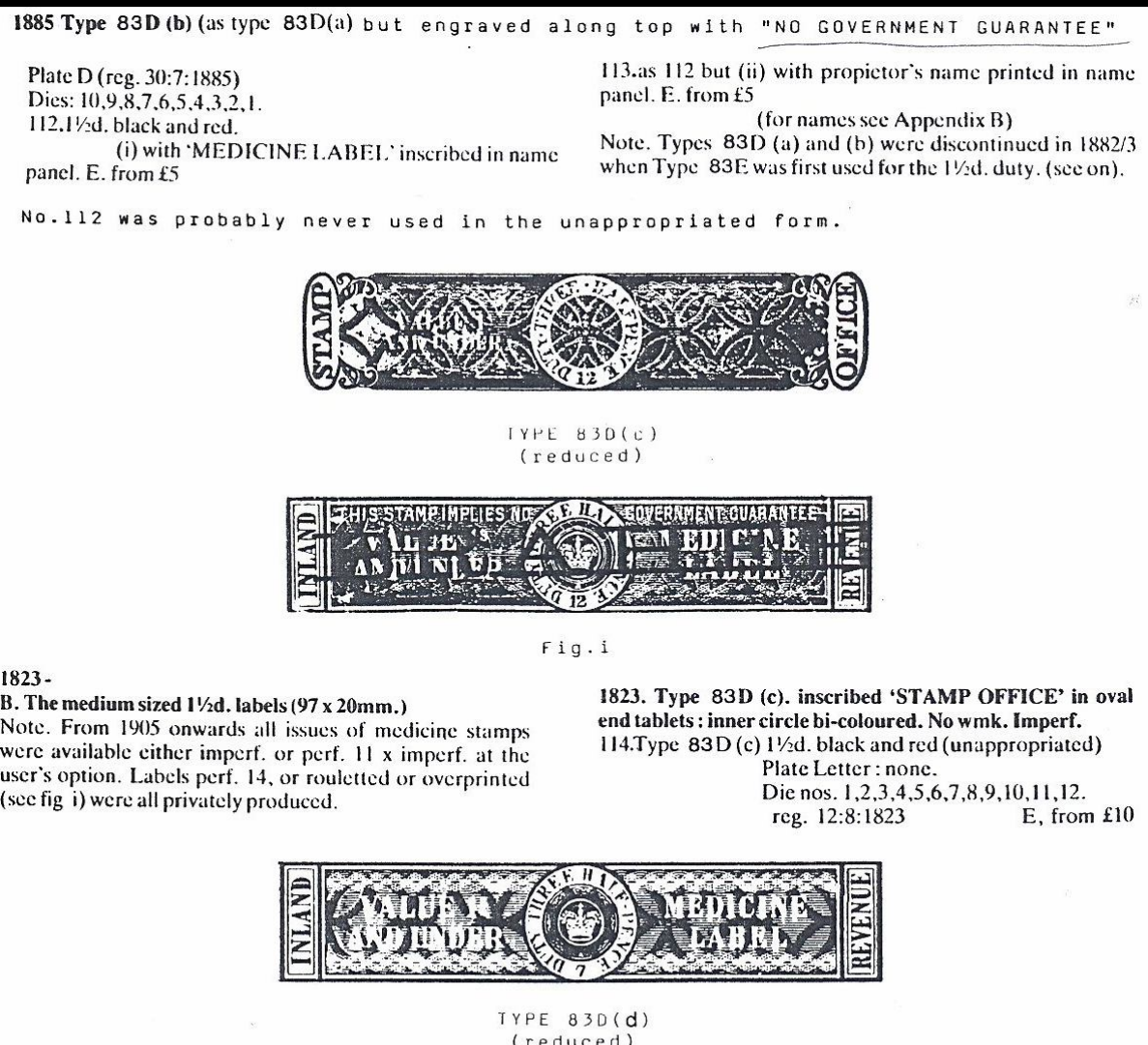

TYPE $830(d)$

1878. Type 83.D (d).Inscribed 'INI.AND REVENUE' in 115.Type 83D(d) 11/2d. black and red (unappropriated) rectangular end tablets. Centre circle in red only. No. wmk. $\quad$ Plate 'A' Dies nos. $1,2,3,4,5,6,7,8,9,10,11,12$. Imperf. reg. 12:2:1878

from $£ 5$

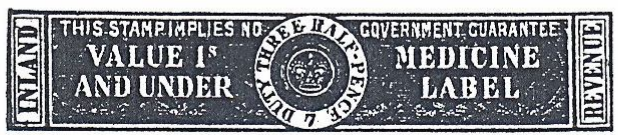


Anexo II

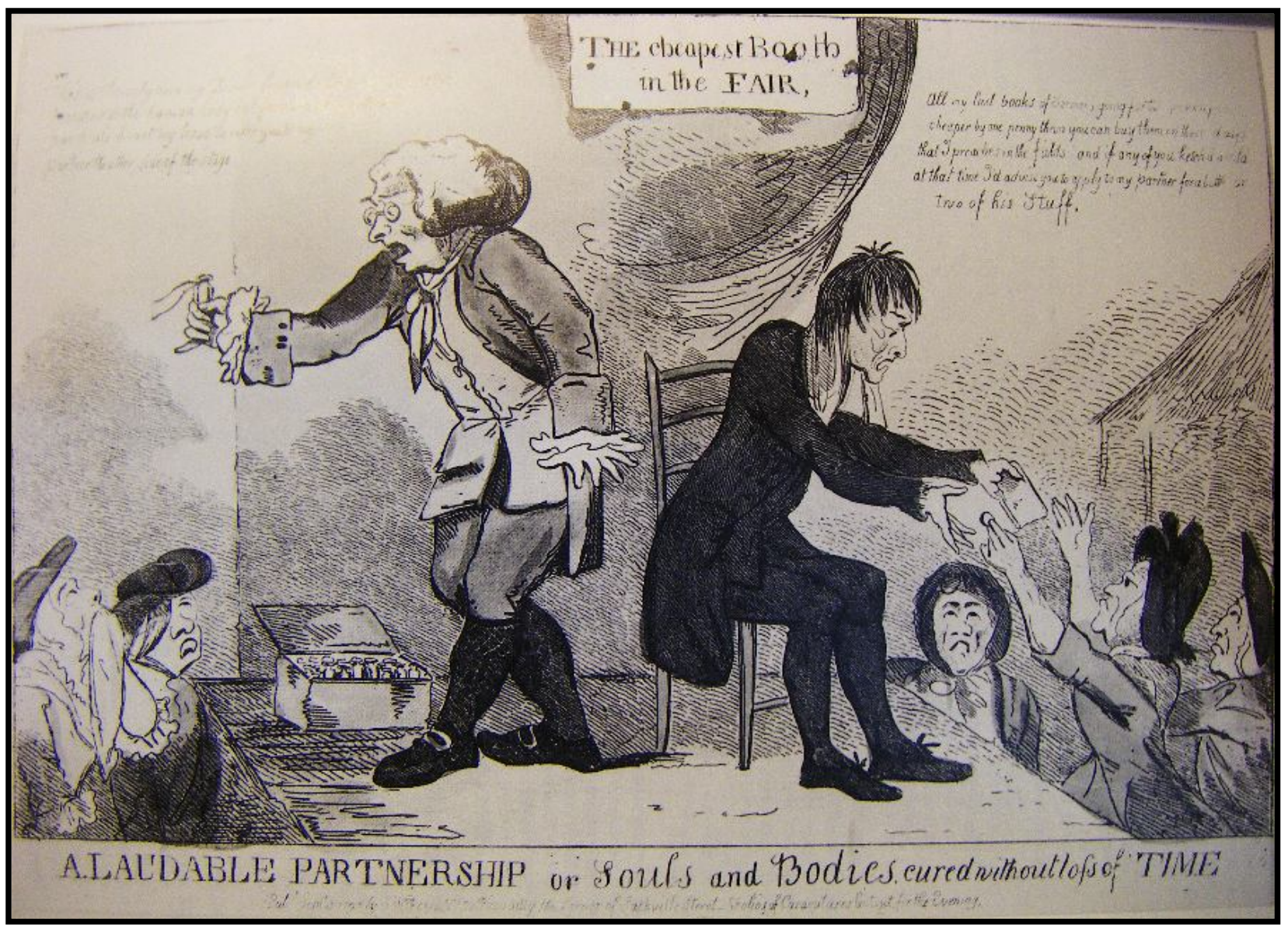

"This is the only cure my Dear friends for every disorder incident to the human body but for cure and comfort to your Souls I must beg leave to refer you to my partner the other side of the stage" *

"All my last books of Sermons going for two pence a piece cheaper by one penny than you can buy them on those days that I preaches in the fields and if any of you ketch'd a cold at that time I'd advise you to apply to my partner for a bottle or two of his Stuff." *

* Textos citados na parte superior da caricatura. 


\section{Anexo III}

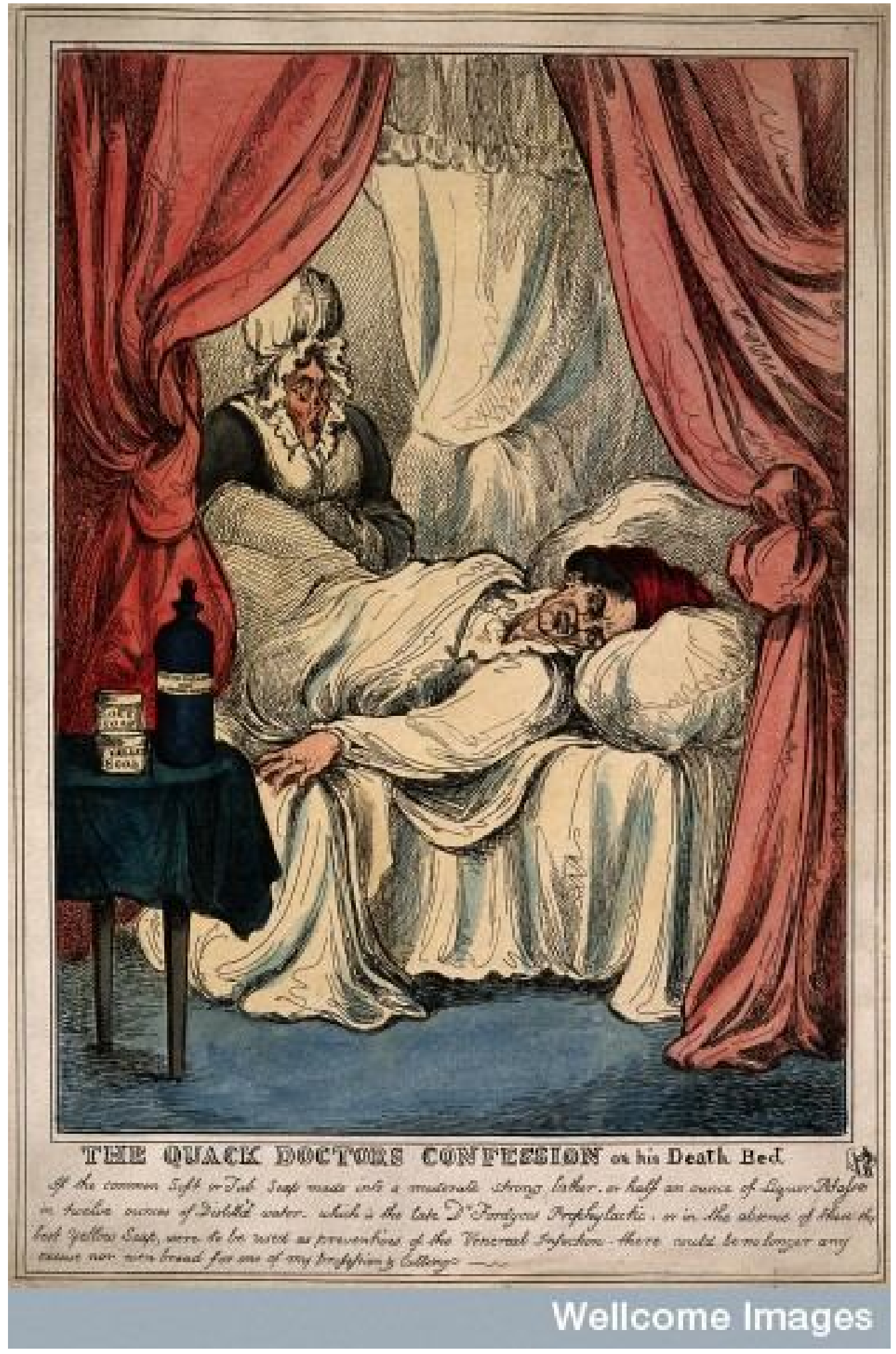




\section{CAPSULES RIEDEL}

Com ollea do rieino

APPROVADAS PRLA INSPECTORI DE HYGIENE

Estas capsulas elasticas, Já bastante conhecidas $\theta$ bəm acceitas no Brazil. são preferiveis ás de outras origens não só por serem mais vantajosas em preço, como principalmente por conservare n-se molhor, devido ao sen bom preparado.

Venda por grosso: J. D. RIEDEL, Borlim.

A GENTE NO RIO DE JANEIRO

(2)

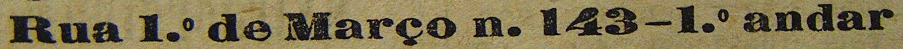

DEPOSITO EM S. PAULO

Companhia do Drogas do Estado do S. Paulo 3 - RUA DIREITA-3 - $-10-1$ 


\section{Anexo V}

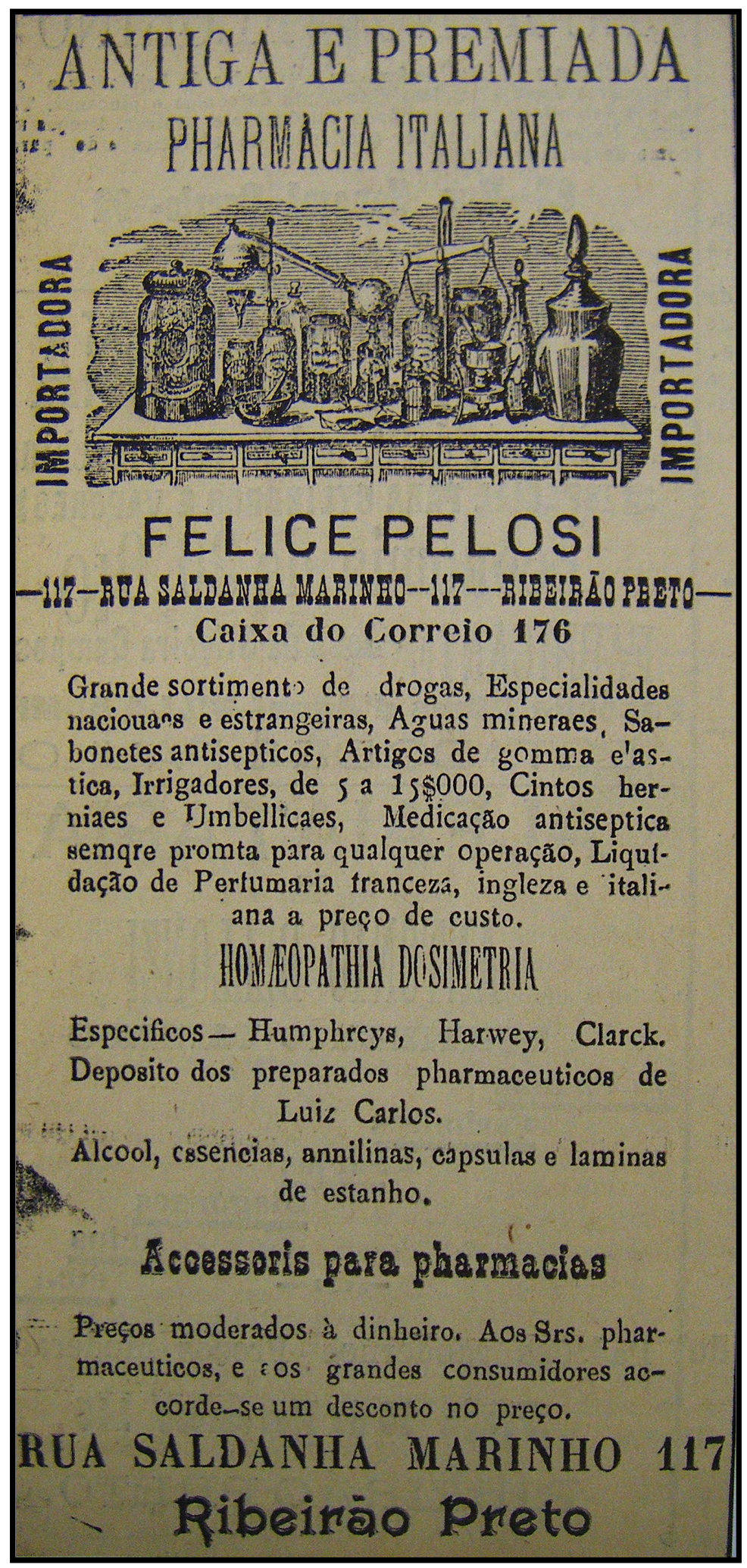




\title{
Anexo VI
}

\section{Silva Araujo \& C. pharmacia drogaria e fabrica de productos chimicos e pharmaceuticos}

\author{
GERENOTA E FISOALISACÃO
}

dos fundadores Luiz Eduardo da Silva Araujo e Francisco Manoel da Silva Araujo

I \& 3 RUA PRIMERIO DE MARCO, I58 RUAA D. ANA NERY -《K RIO DE JANEIRO G R A N D E S T O C K

Soluçāo de antipyrina Silva Araujo.

Soluçăo de bromureto de estroncio Silva Araujo.

Soluẹào de bromureto de potassio Silva Araujo.

Solnęão de bromureto de sodio Silva Araujo.

Soluçāo elorhydrica Silya Araujo.

Soluetio de hypprurato de calcio Silva Araujo.

Soluęäo de hyppurato de Lithio Silva Araujo.

Solução iodo-tanniea Silva A raujo.

Solução de iodureto de estroneio Silva Arauio.

Soluẹão normal de iodo ferco para xarope Dupasquier, 100 grammas.

Solução de iodureto de potassio Silva Arauio.

Soluçáo de iodureto de sodio Sitva Aranjo.

Solucāo polybroma da Sisva Azaujo.

VIXHOS-Cajú; eajú arsenio phospo-taleareo; eajú ferruginoso; eajú iodo-quinado: eaju quino-phospo-talcureo; iodio tannieo phosphatado; jurubeba; jurnbeba ferruginoso; Kola ; peptona; pyrophosphatado ferro queuina flycerinada; quina ealumba e absinthio, quinio; RECONSTI:

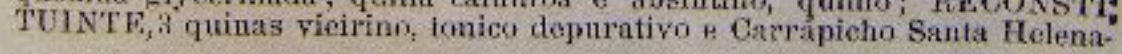

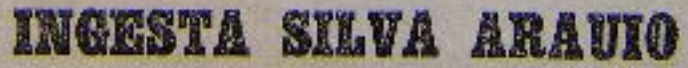

Alimento completo para reparax as linese para uso dos convales-

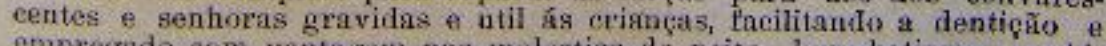
empregado com vantagem nas molestias do peito, lymphatiamo, rachiismo - Lata 23 duzia 20 stou $-A$ mais uzada ino Erazil. 


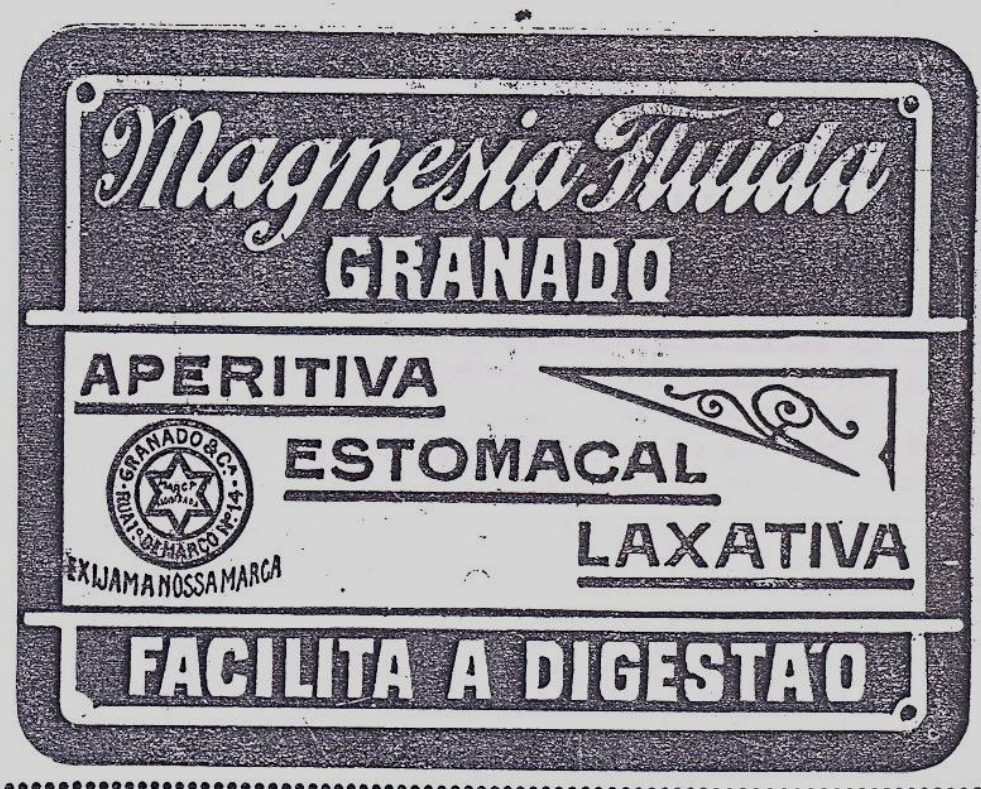

Anemia - Neurasthenia - Depressões Nervosas Fraqueza geral - Convalescença

$\frac{\text { Nevrostenil Granado }}{\text { Sồo Neuro-tonico ntensivo }}$

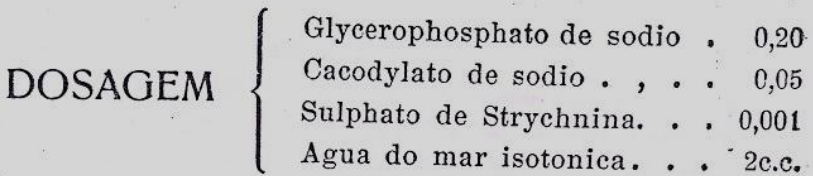

2 c. c. diariamente em injeções subcutaneas ou intramusculares. Series de 12 injecções com 6 a 8 dias de repouso.

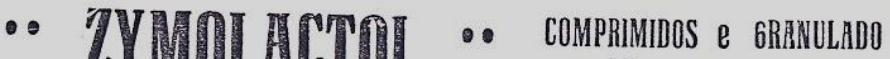

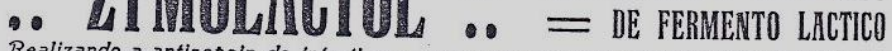
Realizando a antisepsla do infestino, o seu emprego está perfeitamente indicado nos casos de Infecça intestinal, Enferifes (asudas e chronicas). Febre typhoide, Grippe, efc. - Clfilisslmo nas Perfurbaçôes funccionaes do figado e rins e Afec: çöes da pelle. - Exijam sempre ZYMOLACTOL (Comprimidos ou granulado)

Depositarlo Jõ̃o Lopes Rua 11 de Agosto, 35. SÃo PAULO 


\section{Referências bibliográficas}

Fontes na Inglaterra

A Collection of the Public General Statutes, 23 George III, Chapter 62, 1783.

A Collection of the Public General Statutes, 25 George III, Chapter 79, 1785.

A Collection of the Public General Statutes, 42 George III, Chapter 56, 1802.

A Collection of the Public General Statutes, 43 George III, Chapter 73, 1803.

A Collection of the Public General Statutes, 44 George III, Chapter 98, 1804.

A Collection of the Public General Statutes, 52 George III, Chapter 150, 1812.

A Letter to the Governors of the Brighton Dispensary. By a medical practitioner. Brighton: Henry S. King, Bookseller to the Queen Dowager, 1843.

All the Year Round. “A New Humane Society”, Londres, vol. 15, p. 177-80, 1866.

An Enquiry Into the Designs of the late Petition Presented to Parliament by the Company of Apothecaries. With Remarks, how far it deserved Attention. London, Printed for M. Cooper, 1748.

An Essay on Dispensaries; addressed to such of the subscribers as desire that what they give should produce the greatest possible benefit to those whom they wish to befriend: shewing that at a much smaller cost a much greater amount of good might be effected; and that a very large proportion of the income of these institutions is not merely needlessly, but INJURIOUSLY expended. By P. H. Holland, Surgeon. Manchester: Printed and sold by Love \& Barton, Market-Street, 1838.

Bell, J. A concise historical sketch of the progress of pharmacy in Great Britain, from the time of its partial separation from the practice of medicine until the establishment of the pharmaceutical society. Intended as an introduction to the pharmaceutical journal. London: John Churchill, Princes Street, Soho; MacLachlan \& Stewart, Edimburgh; \& Fannin \&Co., Dublin, 1843.

Brown, J. The Doctor. A Lay Sermon for working people, by the author of 'Rab and his friends'. In: Good Words, vol. 2, p. 30-32, 1861.

Bucham, W. Domestic Medicine: or, a Treatise on the Prevention and Cure of Diseases by Regimen and Simple Medicines. London: Printed for A. Strahan; T. Cadell and W. Davies, Strand; and J. Balfour, and W. Crefch, Edinburg, 1805.

Carlyle, J. A. On Medical Quackery and Mr. St. John Long. Fraser's Magazine, London: James Fraser, vol. 1, p. 451-456, 1830.

Chadwick, E. Preventive Police. An article by Sir Edwin Chadwick. Extracted from the "London Review", 1829.

Chapman, J. Medical Reform. The Westminster Review. London: John Chapman, vol. 13, p. 478-530, 1858.

Collection of Statutes, Laws and Statutes, Willian IV (1830-1837), England, p. 325-330, 1831.

Davenport, J. A. Association of Public Sanitary Inspectors. "Rural Sanitation”, 1887. 
Davis, J. B. A popular manual of the art of preserving health; embracing the subjects of DIET, AIR, EXERCISE, GYMNASTICS, GENERAL AND PHYSICAL EDUCATION, OCCUPATIONS, BATHING, CLOTHING, VENTILATION, ETC. ETC. London: Whittaker and Co. Ave-Maria-Lane, 1836.

Fraser's Magazine. Quackery and the Quacked, London: James Fraser, vol. 37, p. 645-57, 1848.

Gamgee, S. Our medical charities: an address delivered at the Annual Meeting of the Birmingham and Midland Counties Branch of the British Medical Association. London: J. \& A. Churchill, New Burlington Street, 1877.

Graham, T. J. Modern Domestic Medicine; or, A Popular Treatise, illustrating the character, symptoms, causes, distinction, and correct treatment, of all diseases incident to the human frame; embracing all the modern improvements in medicine, with the opinions of the most distinguished physicians. London, 1827.

Hannay \& Dietrichsen's almanack. A Catalogue of some of the Articles of Patent Medicines and Perfumery Sold wholesale and retail by Hannay \& Dietrichsen, Pharmaceutical, Dispensing, and Family Chemists and Druggists, Perfumers to her most gracious Majesty, her Majesty the Queen Dowager, and her Royal Highness the Duches of Kent; 63, Oxford Street, London, p. B5-B58, 1842.

Harper, C. J. S. Decisions of the English Scottish and Irish Courts under the Medical Acts 1858 to 1886 and the Dentists Act 1878. Constable \& Co. Ltd. orange Street, London, 1912.

Hawksley, T. The efforts of Society and State to Mitigate the Evils of Deficient Education and Training, pages 49-55. In: Education and Training, considered as a subject for making a compulsory law both efficient and acceptable to the people. London: John Churchill \& Sons, New Burlington Street, 1868.

Heath, William, 1795-1840. THE QUACK DOCTORS CONFESSION on his Death Bed. Coleção iconográfica da Wellcome Library. Gênero caricaturas, n. 20990i.

Helps, Arthur Sir. Health Funds for London: some thought for next summer. London: John W. Parker and Son, West Strand, 1854.

Higginbottom, J. Mothers, Doctors, and Nurses. Nottingham: T. Kirk, St. Peter's Gate, 1843.

Howard, G. W. F. 7th Earl of Carlisle. Sanitary Reform. Speech in the House of Commons, 30th March, 1847, on moving for leave to bring in a Bill for improving the health of towns in England. London, 1847.

Irvine, H. C. The Old D.P.S. A Short History of Charitable Work in Manchester and Salford, 1833-1933. Published by order of the District Provident and Charity Organisation Society of Manchester and Salford, 1933.

Medical Reform, and the Past, Present and Future of Homoeopathy in Great Britain. By a physician practising homoeopathy. London: W. Headland, 15, Princes Street, Hanover Sq. Manchester: H. Turner, 41, Piccadilly, 1856.

Midwifery, Northamptonshire, 18th-19th century, 1790-1804. Material do Arquivo da Wellcome Library, referência MS.6883, datilografado por Christopher Hilton e Richard Aspin. Acesso em 02/12/2008. 
Notes on Sanitary Reform. The Health of Towns. By a Member of the Association for the Promotion of Social Science. London: Simpkin, Mrshall, \& Co. Bristol: Thomas Kerslake \& Co., 1870.

Our Schools of Medicine, and the Coming Medical Struggle. By an Allopathic Practitioner. Edinburgh: Bell \& Bradfute, 12 Bank Street. Simpkin, Marshall, \& Co., London, 1858.

Percival, T. Medical jurisprudence; or A code of ethics and institutes, adapted to the professions of physic and surgery. Manchester, 1794.

Public General Acts, Great Britain. Parliament. Bills. Londres, p. 1740-1745, 1815.

Public General Acts, Great Britain. Parliament. Bills. Londres, p. 480-495, 1852.

Remarks on Medical Reform; in a second letter addressed to the right Hon. Sir James Graham, Bart., one of her Majesty's principal secretaries of State, \& C. By Sir James Clark, Bart., M. D., F. R. S., physician in ordinary to the Queen and to the Prince Albert. London, 1843.

Rentoul, R. R. The reform of our voluntary medical charities: some serious considerations for the philanthropic. London: Bailliere, Tindall, and Cox, 1891.

Report from the Select Committee on Adulteration of Food \&c.; together with the Proceedings of the Committee, Minutes of Evidence, Appendix and Index. Ordered, by The House of Commons, to be Printed, 22 July 1856. In: Reports from Committees: Eleven Volumes. Session 31 January - 29 July 1856, Vol. VIII, 1856.

Report from the Select Committee on Adulteration of Food \&c.; with the Minutes of evidence, and Appendix. Ordered, by The House of Commons, to be Printed, 27 July 1855. In: Reports from Committees: Eight Volumes. Session 12 December - 14 August 1855, Vol. VIII, 1854-5.

Report from the Select Committee on Pharmacy Bill; together with the Proceedings of the Committee, Minutes of Evidence, and Index. Ordered, by The House of Commons, to be Printed, 21 May 1852. In: Reports from Committees: Thirteen Volumes. Session 3 February 1 July 1852, Vol. XIII, 1852.

Reports from select committees on metropolis and town sewers; with proceedings, minutes of evidence, appendices and index. Great Britain. Parliament. House of Commons. Cópia idêntica da edição de 1834, p. 30-40. Shannon: Irish University Press, 1969.

Simpson, W. The Article on Medical Reform, which appeared in no. XXI. of "The British and Foreign, or European Quarterly Review," for July, 1840; and Letters on Medical Subjects, published in the "Lancet", \& C. also Evidence given before the Metropolitan Sanitary Commission (microfilme). Henry Renshaw, Medical Bookseller and Publisher, 356, Strand, 1847.

Stevens, J. Medical Reform; or, Physiology and Botanic Practice, for the people. London: Whittaker and Co., 1849.

The Druggists General Receipt Book: comprising a copious Veterinary Formulary; numerous recipes in Patent and Proprietary Medicines; Druggists' Nostrums, etc.; Perfumery and Cosmetics; Beverages, Dietetic Articles, and Condiments; Trade Chemicals, \&c. with an appendix of useful tables. By Henry Beasley. London: John Churchill, Princes Street, Soho, 1852. 
The Family Doctor being a complete Encyclopaedia of Domestic Medicine and Household Surgery comprising A Full Description of the Human Frame. London: Houlston and Wright $65,1860(?)$.

The Record of Pharmacy and Therapeutics. Being an account of improved Pharmaceutical Preparations, recently $=$ introduced Remedies, and A Catalogue of unadulterated drugs \& chemicals of the General Apothecaries Company. In: Lectures on the Metropolitan GraveYards by Geo. Alfred. Walker \& other Papers, London: published by and for the GENERAL APOTHECARIES COMPANY (Limited), 49, Berners Street, London, 1856.

\section{Fontes em São Paulo}

A. A. S. Seção "Considerações acerca dos preparados pharmaceuticos nacionaes". In: Revista Pharmaceutica, Typografia Hennies Irmãos, R. da Caixa d'Agua, S. Paulo, anno IV, n. 6, p. 103-106, 1898.

A Cidade. Ribeirão Preto, SP: proprietário Antonio Carlos da Silva, redator Dr. Eneas da Silva, anno I, n. 1, 1 jan 1905.

Annaes do Primeiro Congresso Medico Paulista. Seção "Exposição de Hygiene”, p. 371-373, 1916.

Barros, B. Xavier de. Manual Pratico de Medicina Legal. Para uso de estudantes, advogados, autoridades e peritos. São Paulo: Typographia Brazil de Rothschild \& Cia, p. 561-566 e 569$628,1915$.

Boletim de Therapeutica, Pharmacia e Chimica. Seção "O primeiro papel reactivo oppondo-se á mais antiga fraude industrial." Direção de Alfredo Leal e Octavio Veiga (editado pela Sociedade Anonyma "Colombo", Santos - SP). Anno I, n. 2, p. 71-73, junho 1923.

Boletim Mensal de Estatistica Demographo-Sanitaria de São Paulo e dos municipios de Santos, Campinas, Ribeirão Preto, São Carlos, Guaratinguetá e Botucatú com um annexo sobre o Movimento dos Postos Sanitarios do Estado. Seção "Inspectoria de Fiscalização da Medicina e Pharmacia e Verificação de Obitos", São Paulo, Rothschild \& Cia., anno X, n. 11, p. 62-63, nov 1927.

Boletim Trimestral de Estatistica Demographo-Sanitaria de São Paulo. Seção "Policiamento sanitario". São Paulo, Typ. do <<Diario Official〉>, anno XXIV, n. 1, p. 264-266, jan-mar 1917.

Boutin. "Noticiario social. Consejos de esculapio". In: Revista de Medicina. Typographia Hennies Irmãos, R. da Caixa d'Agua, S. Paulo, anno VII, vol. IV, n. 24, p. 58-61, maio 1923.

Brandão, V. "Alguns medicamentos interessantes da flora brazileira". In: Revista Medica de S. Paulo, S. Paulo: Escola Typ. Salesiana, anno VI, p. 334-339, 1903.

Brouardel, P. “A responsabilidade medica”. In: Revista Pharmaceutica, Typographia Hennies Irmãos, R. da Caixa d'Agua, S. Paulo, anno IV, n. 11, p. 167-171, 15 março 1898.

Bueno, A. D. Seção "Do exercicio da medicina, de pharmacia, da obstetricia e da arte dentaria”. In: Lei n. 432 - 3 ago 1896, p. 47-57. Actos do Poder Legislativo. Coleção de Leis e Decretos do Estado de São Paulo, S. Paulo: Typographia do Diario Official, 1896. 
Carvalho, V. de. Decreto N. 87 - de 29 de julho de 1892. Regulamenta a lei n. 43 de 18 de julho do corrente ano, que organiza o serviço sanitário do Estado. In: Coleção de Leis e Decretos do Estado de São Paulo, Atos do Poder Executivo, S. Paulo: Typographia do Diario Official, p. 147-162, 29 julho 1892.

Correio Paulistano. São Paulo: redação R. 15 de nov. 51. Gerente Fernand Dreyfus, anno XL, n. 11.135, p. 3, 7 dez 1893.

Correspondência com diversas autoridades. Do Inspetor-chefe para Dr. Delegado de Polícia de Jaú. In: Saúde Pública - Inspetoria de Fiscalização da Medicina e da Farmácia do Serviço Sanitário - 1929(I)-1929(F) - Sem localidade - Ordem: C06192, p. 47, 2 fevereiro 1929.

Correspondência com diversas autoridades. Do Inspector-chefe para Dr. Juvenal de Toledo Piza (delegado de Costumes e Jogos da Capital). In: Saúde Pública - Inspetoria de Fiscalização da Medicina e da Farmácia do Serviço Sanitário - 1929(I)-1929(F) - Sem localidade - Ordem: c06192, p. 41, 31 janeiro 1929.

Correspondência com diversas autoridades. Do Inspetor-chefe para Sr. Dr. Delegado de Polícia de Jardinópolis. In: Saúde Pública - Inspetoria de Fiscalização da Medicina e da Farmácia do Serviço Sanitário - 1929(I)-1929(F) - Sem localidade - Ordem: C06192, p. 53, 4 fevereiro 1929.

Costa, M. Seção "Algumas considerações sobre a classe pharmaceutica". In: Revista Pharmaceutica, Typografia Hennies Irmãos, R. da Caixa d'Agua, S. Paulo, anno I, n. 3, p. 4750,15 jul 1895.

Diario Popular. São Paulo: propriedade de J. M. Lisboa \& Comp., anno VIII, n. 2813, 3 ago 1892.

Dias, F. B. Seção "A discussão sobre os extractos fluidos na Sociedade Pharmaceutica Paulista”. In: Revista Pharmaceutica, Typographia Hennies Irmãos, R. da Caixa d'Agua, S. Paulo, anno III, n. 6, p. 72-76, 15 out 1897.

Dupuy, E. “A profissão pharmaceutica”. In: Revista Pharmaceutica, Typografia Hennies Irmãos, R. da Caixa dÁgua, S. Paulo, anno VI, n. 2, p. 21-25, 28 fev 1902.

D.V. Seções "Reforma sanitaria" e "Nova lei sanitaria". In: Revista Farmaceutica, Typografia Hennies Irmãos, R. da Caixa dÁgua, S. Paulo, ano 24, n. 23, p. 145-151, 12 dez 1917.

Effe. "Supplemento literario e humoristico. Tratamento "Proprio"”. In: São Paulo Medico. São Paulo: Praça da Sé, 46 (Palacete Equitativa), anno I, vol. 1, n. 3, p. 405, julho 1928.

Ellis, G. Seção "Discurso proferido pelo Dr. Guilherme Ellis". In: Revista Medica de S. Paulo, S. Paulo: Escola Typ. Salesiana, anno II, n. 3, p. 91, 15 mar 1899.

Espinheira, C. "Exercicio illegal da medicina". In: Revista Medica de S. Paulo, S. Paulo: Escola Typ. Salesiana, anno I, n. 7, p. 121, 15 ago 1898.

Fajardo, F. Tratado de Hypnotismo. Rio de Janeiro: Typ. Laemmert \& C., p. I-XVII, 1896.

Favero, F. "Lições e Conferencias.Exercicio da Medicina. Exercicio Illegal. Charlatanismo. Curandeirismo" In: São Paulo Medico. São Paulo: Praça da Sé, 46, anno I, vol. 1, n. 2, p. 194205, junho 1928. 
F.B.D. "Escola de Pharmacia”. In: Revista Pharmaceutica, Typografia Hennies Irmãos, R. da Caixa d'Agua, S. Paulo anno IV, n. 10, p. 169-171, 1899.

F. C. P. Seção "Apontamentos para a historia das campanhas sanitarias no Brasil”. In: Revista de Medicina, Secção de Obras D' 'O Estado de S. Paulo, anno VII, vol. V, n. 25-26, p. 19-21, 21-23, jun-jul 1923.

Fontoura, C. "Limitação das Pharmacias". In: Livro do Primeiro Congresso Brasileiro de Pharmacia, seção "Legislação, Regulamentação e Historia", p. 169-176, 12 a 22 de outubro de 1922.

Freire, D. "Chimica analytica. Os medicamentos officinaes de importação. Pesquizas feitas no laboratorio da Faculdade de Medicina da Côrte.” In: União Medica, p. 639-642, 1891.

Freire, O. Seção "Deontologia Medica. Lição inaugural pelo Dr. Oscar Freire. O curandeirismo", "O perigo do mercantilismo" e "O individualismo pernicioso". In: Revista de Medicina, Secção de Obras D' "O Estado de S. Paulo, anno V, vol. III, n. 18, p. 16-17, 21-23, abr-mai 1921.

Godoy, G. de O. Decreto n. 1439, de 15 de fevereiro de 1907. Approva o regulamento do Laboratorio Pharmaceutico do Estado. In: Actos do Poder Executivo. Coleção de Leis e Decretos do Estado de São Paulo, S. Paulo: Typographia do Diario Official, p. 34-38, 1907.

Gurgel, J. de S. A. "Do exercicio da medicina, pharmacia, obstetricia e arte dentaria". In: Lei n. 240 - de 4 de setembro de 1893. Actos do Poder Legislativo. Coleção de Leis e Decretos do Estado de São Paulo, S. Paulo: Typographia do Diario Official, p. 168-178, 1893.

Giffoni, A. F. A Pharmacia Humoristica. In: Livro do Primeiro Congresso Brasileiro de Pharmacia (12 a 22 de outubro), Rio de Janeiro, p. 63-67, 1922.

Holanda, C. B. de. Seção "Fornecimento de medicamentos". In: Relatorio do Laboratorio Pharmaceutico do Estado, Duprat \& Comp. - Rua Direita, 26 São Paulo, p. 13, 31 dez 1897.

Lobo, J. M. Decreto n. 3876 - 11 de julho de 1925. Reorganiza o Serviço Sanitário e repartições dependentes. In: Atos do Poder Executivo, Coleção de Leis e Decretos do Estado de S. Paulo, São Paulo: Officinas do Diario Official, p. 470-475, 1925.

Lucas, V. "Do estabelecimento de normas restrictivas e energicas na approvação das especialidades pharmaceuticas". In: Livro do Primeiro Congresso Brasileiro de Pharmacia. Seção: "Legislação, Regulamentação e Historia". Comissão de redação: farmacêuticos Paulo Seabra, Souza Martins e Alberto Giffoni, p. 165-167, 12 a 22 de outubro de 1922.

Magalhães, F. de. "A vocação medica". In: Revista de Medicina. SP: secção de obras D'O Estado de S. Paulo, anno II, n. 7, p. 33-35, maio 1918.

Meira, R. Seção "Dos deveres dos medicos. Conferencia feita no "Centro Academico Oswaldo Cruz" pelo Prof. Dr. Rubião Meira, aos 26 de abril de 1920". In: Revista de Medicina, Cardozo, Filho \& C. Rua Sto Antonio, 9, São Paulo, anno IV, n. 15, p. 7-18, 1 jun 1920.

Mello Filho, A. B. de A. "Douta Congregação". In: Terceira Memoria Historica da Escola de Pharmacia, Odontologia e Obstetricia de São Paulo relativa ao biennio de 1907 a 1908. S. Paulo: Duprat \& Comp., p. 3-42, 1909. 
Montenegro, B. "Comunicações escriptas: Organizações hospitalares na guerra". In: Boletim da Sociedade de Medicina e Cirurgia de S. Paulo, Secção de Obras D'O Estado de S. Paulo, vol. 2 (2 ${ }^{\text {a }}$ série), n. 4, p. 68-73, junho 1919.

Penteado, M. S.; Queiroz, L. M. P. de. Parecer da Comissão de Titulares sobre as Tarifas Aduaneiras para os Productos Chimicos Puros e Impuros. Boletim da Sociedade de Pharmacia e Chimica de São Paulo. São Paulo: Pap. e Typ. Esperia, anno 1, n. 1, 31 julho 1926, p. 7-10.

Pereira, J. R. Boletim da Sociedade de Medicina e Cirurgia de S. Paulo, vol. XIII, $3^{\text {a }}$. série, n. 4, p. 198-201, jun 1929.

Primeiro Congresso Brasileiro de Pharmacia (livro do). Seções: "Legislação, Regulamentação e Historia" e "A Pharmacia Humoristica". Comissão de redação: farmacêuticos Paulo Seabra, Souza Martins e Alberto Giffoni, 12 a 22 de outubro de 1922.

Queiroz, J. P. de. Seção "Escola Livre de Pharmacia. Decreto n. 780 de 26 de abril de 1900". In: Revista Medica de S. Paulo, S. Paulo: Escola Typ. Salesiana, ano III, n. 5, p. 109-110, 15 maio 1900.

Queiroz, L. M. P. de. Seção editorial "Revista Pharmaceutica". In: Revista Pharmaceutica, Typografia Hennies Irmãos, R. da Caixa d’ Agua, S. Paulo, anno VI, n. 1, p. 1-3, 1902.

Queiroz, L. M. P. de. Seção "Pharmacopéa Brasileira" (publicação escrita em 6 de dez de 1906). In: Revista Pharmaceutica, Typografia Hennies Irmãos, R. da Caixa d'Agua, S. Paulo, anno XII, n. 1, p. 1-4, 31 jan 1907.

Queiroz, L. M. P. de. Seção "Da Cooperativa Pharmaceutica”. In: Legislação, Regulamentação e História. Primeiro Congresso Brasileiro de Pharmacia. RJ, p. 159-163, 1922.

Revista Medica de S. Paulo. Seção "Drogaria Baruel”. S. Paulo: Escola Typ. Salesiana, anno I, n. 2, p. 210-212, 1899.

Revista Medica de S. Paulo. Seção "Alguns Medicamentos Interessantes da Flora Brazileira”, S. Paulo: Escola Typ. Salesiana, anno V, p. 334-339, 1903.

Revista Pharmaceutica. Seção "A Cooperativa Pharmaceutica”, Typographia Hennies Irmãos, R. da Caixa d'Agua, S. Paulo, anno II, n. 22, p. 117-119, 15 fev 1897.

Revista Pharmaceutica. Seção "Chronica. Productos extrangeiros", Typographia Hennies Irmãos, R. da Caixa d'Agua, S. Paulo, anno I, n. 4, p. 69-87, 15 ago 1895.

Revista Pharmaceutica. Typographia Hennies Irmãos, R. da Caixa d'Agua, S. Paulo, p. 167, 1899.

Revista Pharmaceutica. Typografia Hennies Irmãos, R. da Caixa d'Agua, S. Paulo, anno X, n. 2, p. 17-27, 28 fev 1905.

Revista Pharmaceutica. Seção "Liberdade profissional". Typografia Hennies Irmãos, R. da Caixa d'Agua, S. Paulo, anno I, n. 2, p. 23-25, 1895.

Ribeiro, E. B. "Os annuncios e a Saude Publica". In: São Paulo Medico, São Paulo: Praça da Sé, 46 (Palacete Equitativa), anno I, vol. 1, n. 3, p. 317-331, jul 1928. 
Rocha, R. G. "Do Syndicato e seus fins". In: São Paulo Medico. São Paulo: Praça da Sé, 46 (Palacete Equitativa), anno I, vol. 1, n. 1, p. 33-45, maio 1928.

Rodrigues, N. "Liberdade profissional em medicina". In: Revista Medica de S. Paulo. S. Paulo: Escola Typ. Salesiana, anno II, n. 6, p. 170-182, 15 jun 1899.

Santos, G. F. dos. Livro do Enfermeiro e da Enfermeira. Rio de Janeiro: Typ. Do Jornal do Commercio, de Rodrigues \& C., cap. VIII, 1916.

Sciencia Medica. Rio de Janeiro: redação Rua Sachet n. 8 - 1². Andar. Seção "O Instituto Medicamenta”, anno V, n. 9, p. 545-549, set 1927.

S. "Os novos impostos sobre os medicamentos". In: Revista Pharmaceutica, Typografia Hennies Irmãos, R. da Caixa d'Agua, S. Paulo, anno IV, n. 9, p. 159-161, 15 jan 1899.

Soares, S. de M. "Apreciações clinicas sobre alguns preparados do PHARMACEUTICO SAMUEL de MACEDO SOARES". In: Gazeta Clinica, São Paulo: Rua de S. Bento n. 45, anno VI, n. 12, p. 125, dez. 1908.

Sociedade Pharmaceutica Paulista. Seção "Chronica: Sociedade Pharmaceutica Paulista". In: Revista Pharmaceutica, Typographia Hennies Irmãos, R. da Caixa d'Agua, S. Paulo, anno I, n. 2, p. 41-42, 15 jun 1895.

Souza, J. V. de. "Inicio e Execução da Idéa". In: Primeira Memoria Historica da Escola de Pharmacia, Odontologia e Obstetricia do Estado de S. Paulo sobre os factos que lhe são inherentes, desde a idéa de sua creação, até 31 de Dezembro de 1903. S. Paulo: Duprat \& Comp., p. 11-58, 1904.

Toledo, A. de. "Do exercicio da medicina, da pharmacia, da obstetricia e da arte dentaria". In: Lei n. 432 - de 3 de agosto de 1896. Actos do Poder Legislativo. Coleção de Leis e Decretos do Estado de São Paulo. S. Paulo: Typographia do Diario Official, p. 38-56, 1896.

Vasconcellos, J. F. M. de; Hollanda, C. B. de. Seção "Medicamentos Artificiaes". In: Revista Pharmaceutica, Typographia Hennies Irmãos, R. da Caixa d'Agua, S. Paulo, anno V, n. 52, p. 53-54, 15 ago 1899.

Vergely, L. P. A. "Introducção". In: Tratado completo de medicina popular. Jaú: Commercio do Jahu, 1922.

Zuquim, A.; Moura, M. de; D’Almeida, T.; Queiroz, L.M.P. de; Genofre, S.; Vasconcellos, J.F.M. de; Valladão, M.; Azevedo, A.M.; Rudge, J.G.; Fausto, O.; Vianna, M.; Magalhães, B. de; Cruz, L.G. de A.; Jardim, L.F.; Brasiliense, A.; Carvalho, A. de; Vianna, A.; Puiggari, I.; Moura, F. De; Lima, A.G. d'Almeida; Comenale, C.; et al. Seção "Representação apresentada ao Director do Serviço Sanitario em Maio de 1898 pelas classes Medicas de S. Paulo. Cidadão Dr. Director do Serviço Sanitario", Typographia Hennies Irmãos, R. da Caixa d'Agua, S. Paulo. In: Revista Pharmaceutica, anno IV, n. 36, p. 23, 15 maio 1898.

\section{Bibliografia geral}

Agência Nacional de Vigilância Sanitária. Medidas para ampliar qualidade, segurança e eficácia dos medicamentos. Informes técnicos institucionais. Rev Saúde Pública, vol. 37, n. 6, p. 821-824, 2003.

Almeida, M. de. Circuito aberto: idéias e intercâmbios médico-científicos na América Latina nos primórdios do século XX. Hist Cienc Saúde-Manguinhos, vol. 13, n. 3, p. 733-757, 2006. 
Almeida, M. de. Combates sanitários e embates científicos: Emílio Ribas e a febre amarela em São Paulo. História, Ciências, Saúde-Manguinhos, vol. 6, n. 3, p. 577-607, 2000.

Andrade, M. de. A Medicina dos Excretos. In: Namoros com a Medicina, Livraria Martins Editora, São Paulo, 1939.

Annals of the Royal College of Physicians, 1518-1915: a guide and listing to the microfiche edition. Reading: Adam Matthew Publications, 43 p., 1991.

Arrais, P. S. D.; Coelho, H. L. L.; Batista, M. do C. D. S.; Carvalho, M. L.; Righi, R. E.; Arnau, J. M.. Perfil da automedicação no Brasil. Rev. Saúde Pública, vol. 31, n. 1, p. 71-7, 1997.

Barreto, M. R. N.; Aras, L. M. B. de. Salvador, cidade do mundo: da Alemanha para a Bahia. Hist Cienc Saúde-Manguinhos, vol. 10, n. 1, p. 151-172, 2003.

Barros, J. A. C. Políticas farmacêuticas a serviço dos interesses da saúde? Brasília, UNESCO: Agência Nacional de Vigilância Sanitária, 2004.

Barros, J. História comparada. Um novo modo de ver e fazer a história. Revista de História Comparada, vol. 1, n. 1, p. 1-30, 2007.

Behrendt, S. D. Markets, Transaction Cycles and Profits: Merchant Decision Making in the British Slave Trade. The William and Mary Quarterly, v. 58, part 1, p. 171-204, 2001.

Benchimol, J. L. Domingos José Freire e os primórdios da bacteriologia no Brasil. Hist Cienc Saude-Manguinhos, vol. 2, n. 1, p. 67-98, mar-jun 1995.

Benchimol, J. L. A instituição da microbiologia e a história da saúde pública no Brasil. Ciência \& Saúde Coletiva, vol. 5, n. 2, p. 265-292, 2000.

Bermudez, J. A. Z. Indústria Farmacêutica, Estado e Sociedade. São Paulo: Hucitec, 1995.

Berridge, V. 'A Peculiar Sopor': Opium Poisoning and the Longevity Debate. In: Opium and the people. Opiate use and drug control policy in nineteenth and early twentieth century England. Free Association Books/London/New York, p. 75-86, 1999.

Bertucci, L. M. Saúde: arma revolucionária. São Paulo - 1891/1925. Campinas: Coleção Tempo \& Memória, p. 19-80, 1997.

Bilac, O. As Cartomantes. In: As Cem Melhores Crônicas Brasileiras. Org.: Joaquim Ferreira dos Santos. Rio de Janeiro: Objetiva, p. 53-56, 2007.

Bloch, M. História comparada e Europa. In: História e historiadores. Tradução: Telma Costa. Lisboa: Editorial Teorema, Lda., p. 111-150, 1995.

Booth, R. G. A Catalogue of the Revenue Stamps of the U. K., Isle of Man, Channel Islands and Eire. Medicine Duty (Tax Stamps), pp. 337-370, 1990.

Bown, S. R. The Age of Scurvy. How a Surgeon, a Mariner and a Gentleman helped Britain win the Battle of Trafalgar. Summersdale Publishers Ltd, 2005.

Braudel, F. Civilização Material, Economia e Capitalismo. Lisboa, Cosmos, vol. 1, 1970. 
Brown, P. S. The providers of medical treatment in mid-nineteenth-century Bristol. Medical History, vol. 24, p. 297-314, 1980.

Burnby, J. The Origins and Development of Pharmacy in North Eastern England. Pharmaceutical Historian, vol.25, n. 3, p. 8-12, 1995.

Burt, D. G. An examination of the pharmaceutical responses to the implementation of the Chemists and Druggists Register: the transformation of a trade into a profession, pages 25-33 and 54-56, 1999.

Bynum, W. F. Rise of science in medicine, 1850-1913. In: The western medical tradition: 1800 to 2000. Cambridge: Cambrigde University Press, 2006.

Calainho, D. B. Jesuítas e Medicina no Brasil Colonial. Tempo, Rio de Janeiro, n. 19, p. 6175, 2005.

Campos, M. A. Pourchet. O ensino farmacêutico dentro da atual Universidade Brasileira. São Paulo, 1959.

Campos, M. A. Pourchet. Perfil do Ensino Farmacêutico no Brasil. Rio de Janeiro, 1966.

Cardoso, C. F.; Brignoli, H. P. O método comparativo na História. In: Os métodos da história. Rio de Janeiro: Edições Graal, p. 409-419, 2002.

Careli, S.S. As transformações no ofício de partejar nas décadas iniciais da República no Rio Grande do Sul. Vestígios do passado: a história e suas fontes. IX Encontro Estadual de História. Associação Nacional de História. Seção Rio Grande do Sul - ANPUH-RS, p. 1-13, 2008.

Carneiro, H. Transformações do significado da palavra "droga": das especiarias coloniais ao proibicionismo contemporâneo. In: Álcool e drogas na história do Brasil, Renato Pinto Venâncio \& Henrique Carneiro (orgs.), Editora PUC Minas, São Paulo, p. 11-27, 2005.

Carneiro. H. Filtros, mezinhas e triacas: as drogas no mundo moderno, Xamã Editora, São Paulo, 1994.

Castro Santos, L. A. de; Faria, L. Poder, Ideologias e Saúde no Brasil da Primeira República: ensaio de história sociológica. In: Hochman, Gilberto; Diego Armus (org.) Cuidar, controlar, curar: ensaios históricos sobre saúde e doença na América Latina e Caribe. Ed. Fiocruz, Rio de Janeiro, p. 249-93, 2004.

Chalhoub, S.; Marques, V. R. B.; Sampaio, G. dos R.; Sobrinho, C. R. G. Artes e ofícios de curar no Brasil: capítulos de história social. Campinas: Ed. da Unicamp, 2003.

Cook, G. C. The College of Physicians in the nineteenth century. In: Clinical Medicine. Journal of the Royal College of Physicians of London, vol. 1, n. 3, p. 234-239, 2001.

Cope, Z. The Royal College of Surgeons of England. A History. Anthony Blond, p. 7-21, 3556, 91-99, 1959.

Costa, E. A. Vigilância Sanitária: Proteção e Defesa da Saúde. Capítulo I, p. 29-65, Hucitec/Sobravime, São Paulo, 1999. 
Costa, E. A.; Rozenfeld, S. Constituição da vigilância sanitária no Brasil, Marcos históricos e conceituais. In: Fundamentos da vigilância sanitária, Rio de Janeiro, Fiocruz, p. 15-40, 2000.

Costa, N. do R.. Lutas urbanas e controle sanitário: origens das políticas de saúde no Brasil. Editora Vozes, Rio de Janeiro, 1985.

Crellin, J. K. Home Medicine: The Newfoudland Experience, McGill-Queen's University Press, p. 3-15, 1994.

Cunha, L. A. O ensino superior na Primeira República. In: A universidade temporã. O ensino superior, da Colônia à Era Vargas. São Paulo: Editora Unesp, p. 133-204, 2007.

Citrynowicz, M. M. Origens e trajetórias da indústria farmacêutica no Brasil. São Paulo: Narrativa Um, 192 p., 2007.

Dicionário Histórico-Biográfico das Ciências da Saúde no Brasil (1832-1930). Casa de Oswaldo Cruz, Fundação Oswaldo Cruz. Disponível em: http://www.dichistoriasaude.coc.fiocruz.br/iah/P/verbetes/escfarsp.htm. Acesso em 03 out 2009.

Edler, F. C. Boticas \& pharmacias : uma história ilustrada da farmácia no Brasil. Rio de Janeiro, RJ : Casa da Palavra, 2006.

Escohotado, A. Historia general de las drogas. Madrid: Alianza Editorial, vol. 1, p. 9-58, 1989.

Eyler, J. M. Victorian Social Medicine. The ideas and methods of William Farr. Baltimore and London: The John Hopkins University Press, p. 1-12, 1979.

Farrer-Halls, G. Good Health Magic. Back-to-basics Home Remedies in a flash. MQ Publications Limited, 2003.

Fausto, B. História do Brasil. Edusp, São Paulo, 2004.

Figueiredo, B. G. Barbeiros e cirurgioes: atuacao dos praticos ao longo do seculo XIX. Hist. Cienc. Saude-Manguinhos, 6 (2): 277-91, 1999.

Follis, F. Modernização urbana na Belle Époque paulista. São Paulo, Editora Unesp, 2003.

Fontenelle, J. P. O Medico Sanitarista. In: Algumas questões de administração sanitaria. Rio de Janeiro: Est. Graphico Canton \& Reile, p. 7-45, 1941.

Foucault, M. Microfísica do poder. São Paulo: Editora Paz e Terra, 2006.

Foucault, M. O Nascimento da Clínica. Rio de Janeiro: Forense-Universitária, 1977.

Fraser, J. A. Relatório Medical Officer of Health. Flaxton, England. Rural District Council, 1950.

Furtado, C. The economic growth of Brazil. A survey from colonial to modern times. Ricardo W. de Aguiar e Eric Charles Drysdale (trads.), University of California Press, Berkeley e Los Angeles, 1965. 
Gioda, A.; Aquni Neto, F. R. de. Considerações sobre estudo de ambientes indistriais e não industriais no Brasil: uma abordagem comparativa. Cad. Saúde Pública, Rio de Janeiro, vol. 19, n. 5, p. 1389-1397, set-out 2003.

Giovanni, G. A produção farmacêutica antes de 1945. In: A Questão dos Remédios no Brasil. Livraria e Editora Polis, São Paulo, 1980.

Giumbelli, E. Heresia, doença, crime ou religião: o Espiritismo no discurso de médicos e cientistas sociais. Revista de Antropologia, vol. 40, n. 2, p. 31-82, 1997.

Gladstone, D. Introduction: 'Edwin Chadwick and Public Health: Problems and Solutions'. In: Public Health, sanitation and its reform, Routledge/Thoemmes Press, 1997.

Goodwin Junior, J. W. Novos produtos para novos tempos: anúncios em jornais diamantinenses, 1900-1914. In: XI Seminário sobre a Economia Mineira: Economia, História, Demografia e Políticas Públicas, de 24 a 27 de agosto de 2004.

Gorsky, M.; Sheard, S. (eds.). Financing medicine: the British experience since 1750, Routledge Studies in the Social History of Medicine, No. 24, London and New York: Routledge, 2006.

Guimarães, M. R. C. Chernoviz e os manuais de medicina popular no Império. História, Ciências, Saúde-Manguinhos, vol. 12, n. 2, p. 501-514, mai-ago 2005.

Halliday, S. Death and miasma in Victorian London: an obstinate belief. British Medical Journal, vol. 323, p. 22-29; 1469-1471, 2001.

Hanley, J. G. All actions great and small: English Sanitary Reform, 1840-1865, p. 21-36; 219229, 1999.

Hochman, G. A Era do Saneamento. Editora Hucitec, São Paulo, 2006.

Hodgson, B. Drink Me: Laudanum and Other Traditional Opium Medicines. In: In the Arms of Morpheus. The Tragic History of Laudanum, Morphine and Patent Medicines. Greystone Books, 2001.

Hogarth, S. J. Townend and the Manchester Infirmary: a plebeian patient in the Industrial Revolution. In: Medicine, Charity and Mutual Aid. The Consumption of Health and Welfare in Britain, c. 1550-1950. Org.: Anne Borsay and Peter Shapely, p. 91-109, 2007.

Holanda, S. B. de. Botica da Natureza. In: Caminhos e Fronteiras, Livraria José Olympio Editora, Rio de Janeiro, p. 85-104, 1957.

Holloway, S. W. F. Royal Pharmaceutical Society of Great Britain 1841-1991. A political and social history. London, The Pharmaceutical press, 1991.

Holloway, S. W. F. The Apothecaries' Act, 1815: a Reinterpretation. Med Hist., vol. 10, n. 2, p. 107-129, 1966.

Horner, J. S. Medical Ethics and the Regulation of Medical Practice with particulat reference to The Development of Medical Ethics within The british Medical Association 1832-1993, pages 38-40 and 119-122, 1995.

Hunting, P. A History of the Society of Apothecaries. England: BAS Printers Limited, pp. 216-226, 1998. 
Ibañez, N.; Fernandes, S. C. G.; Faria, M.; Wen, F. H.; Sant'Anna, O. A. De Instituto Soroterápico a Centro de Medicina Experimental: institucionalização do Butantan no período de 1920 a 1940. Cadernos de História da Ciência, vol. 2, n. 2, p. 77-103, janeiro-junho 2006.

Inkster, I. Marginal Men: Aspects of the Social Role of the Medical Community in Sheffield 1790-1850. In: Health Care and Popular Medicine in Nineteenth Century England: Essays in the Social History of Medicine. John Woodward and David Richards (editors), 1977.

Iyda, M. Cem anos de saúde pública: a cidadania negada. Editora Unesp, São Paulo, 1993.

Johnson, S. The ghost map: the story of London's most terrifying epidemic and how it changed science, cities, and the modern world. New York: Riverhead; London: Turnaround, 2006.

Kury, L. Homens de ciencia no Brasil: imperios coloniais e circulacao de informacoes. 17801810. Hist. cienc. saude-Manguinhos, vol. 11, suppl. 1, p.109-129, 2004.

Lima, N. T.; Hochman, G. Pouca Saúde e Muita Saúva: sanitarismo, interpretações do país e ciências sociais. Ciência e Saúde Coletiva, vol. 5, n. 2, p. 493-533, 2000.

Lobban, R. D. Edinburgh and the Medical Revolution, p. 4-10, 1980.

Lopes, N. M. Automedicação: algumas reflexões sociológicas. Sociologia, problemas e práticas, n. 37, p. 141-165, 2001.

Loudon, I. Medical practitioners 1750-1850 and medical reform in Britain. In: Medicine in Society, Andrew Wear (ed.), Cambridge University Press, 1992.

Loyola-Filho, A. I. de; Lima-Costa, M. F.; Uchôa, E. Bambuí Project: a qualitative approach to self-medication. Cad. Saúde Pública, vol. 20, n. 6, p. 1661-9, 2004.

Machado, R. Por uma genealogia do poder. In: Microfísica do poder. Michel Foucault. São Paulo: Editora Paz e Terra, p. VII-XXIII, 2006.

Machado, R.; Loureiro, A.; Luz, R.; Muricy, K. Danação da Norma: a medicina social e constituição da psiquiatria no Brasil, p. 153-246, 1978.

MacNalty, A. S. The History of State Medicine in England. In: The Journal of the Royal Institute of Public Health and Hygiene, v 10, Jan-Dec, p. 96-108, 1946.

Manchester, A. K. British Pre-eminence in Brazil: Its Rise and Decline. Chapel Hill, 1953.

Marinho, M. G. S. M. C. Trajetória da Faculdade de Medicina da Universidade de São Paulo: aspectos históricos da "Casa de Arnaldo". São Paulo: Faculdade de Medicina da Universidade de São Paulo, 2006.

Marland, $\mathrm{H}$. The medical activities of mid-nineteenth-century chemists and druggists, with special reference to Wakefield and Huddersfield. Medical History, vol. 31, p. 415-439, 1987.

Marques, M. C. C.; Cunha, L. O Discurso da Ciência e a Ação do Estado - a vida dos trabalhadores sob os cuidados da Saúde Pública em São Paulo entre as décadas de 1930-50. 2006. In: III Simpósio Brasileiro de Vigilância Sanitária, 2006, Florianópolis. Anais do III Simpósio Brasileiro de Vigilância Sanitária. São Paulo: REVISA - Revista Brasileira de Vigilância Sanitária, vol. 2, 2006. 
Marques, M. C. C.; Ibañez, N. Questões sobre Política de Vigilância Sanitária no Brasil. In: Vigilância Sanitária: Teoria e Prática. Maria Cristina da Costa Marques, Marisa Lima Carvalho, Dalma da Silveira, Paulo Carrara de Castro, Nelson Ibañez (orgs.), Rima Editora, São Paulo, p. 1-14, 2006.

Marques, V. R. B. Natureza em boiões: medicina e boticários no Brasil setecentista. Campinas, SP: Editora da Unicamp, Centro de Memória, 1999.

Massie, L. The role of women in mental health care in $19^{\text {th }}$ century England. International History of Nursing Journal, vol. 1, n. 2, pp. 39-51, 1995.

McLaren, A. The Early Birth Control Movement: an Example of Medical Self-Help. In: Health Care and Popular Medicine in Nineteenth Century England: Essays in the Social History of Medicine. John Woodward and David Richards (editors), 1977.

McWhirter, J.; McCann, D.; Coleman, H.; Calvert, M.; Warner, J. Can schools promote the health of children with asthma? Health Educ Res., vol. 23, n. 6, p. 917-30, dez. 2008.

Merrills, J.; Fisher, J. Retail Pharmacy. In: Pharmacy law and practice. London: Blackwell Science Ltd., p. 83-88, 2001.

Ministério da Saúde. O trabalho dos agentes comunitários de saúde na promoção do uso correto de medicamentos. 2002. Disponível em http://www.opas.org.br/medicamentos/docs/uso-med-acs.pdf. Acesso em 05 de junho de 2006.

Morson, A. F. Pharmacy in the 1840s: The wholesale chemists and druggists. Pharmaceutical Historian, vol. 21, n. 4, pp. 3-9, 1991.

Mota, A. Tropeços da Medicina Bandeirante: Medicina Paulista entre 1892-1920. Edusp, São Paulo, 2005.

Mota, A.; Santos, M. A. C. dos. Entre algemas e vacinas. Medicina, polícia e resistência popular na cidade de São Paulo (1890-1920). Revista Novos Estudos Cebrap, n. 165, p. 152168, 2003.

Mott, M. L.; Muniz, M. A.; Alves, O. S. F.; Maestrini, K.; Santos, T. dos. Médicos e médicas em São Paulo e os Livros de Registros do Serviço de Fiscalização do Exercício Profissional (1892-1932). Ciência \& Saúde Coletiva, vol. 13, n. 3, p. 853-868, 2008.

Mott, M. L.; Alves, O. S. F. Farmacêuticas em São Paulo (1901-1919). Boletim do Instituto de Saúde, n. 38, p. 24-27, abril de 2006.

OMS - Organização Mundial de Saúde. The Role of the Pharmacist in Self-Care and SelfMedication, p. 2-7, 1998.

Palmegiano, E. M. Health and British Magazines in the Nineteenth Century. The Scarecrow Press, Inc. Lanham, Md., \& London, 1998.

Parry, N.; Parry, J. The rise of the Medical Profession. A Study of Collective Social Mobility. Croom Helm London, pp. 104-136, 1976. 
Paulo, L.G.; Zanini, A.C. Automedicação no Brasil. Rev. Ass. Med. Bras., vol. 34, p. 69-75, 1988.

Peterson, M. J. The Medical Profession in Mid-Victorian London. University of California Press, p. 5-40, 1978.

Pfuetzenreiter, M. R. A ruptura entre o conhecimento popular e o científico em saúde. ENSAIO - Pesquisa em Educação em Ciências, vol. 3, n. 1, p. 1-15, 2001.

Pharmacy Act, 1954. In: Acts of Parliament 2 \& 3 Eliz. 2 capítulo 61. Londres: Swift (Printing \& Duplicating), Ltd., p. 1-19, 1954. Disponível em: www.opsi.gov.uk/acts/acts1954/pdf/ukpga_19540061_en.pdf

Pimenta, T. S. Barbeiros-sangradores e curandeiros no Brasil (1808-1828). História, Ciências, Saúde-Manguinhos, vol. 5, n. 2, p. 349-372, 1998.

Pimenta, T. S. Transformações no exercício das artes de curar no Rio de Janeiro durante a primeira metade do Oitocentos. História, Ciências, Saúde-Manguinhos, Rio de Janeiro, v. 11, n. supl. 1, p. 67-92, 2004.

Porter, R. The Greatest Benefit to Mankind. A Medical History of Humanity from Antiquity to the Present. Londres: Fontana Press, Harper Collins Publishers, 1997.

Prado Júnior, C. A República Burguesa (1889-1930). In: História Econômica do Brasil. São Paulo: Editora Brasiliense, p. 207-283, 2008.

Queiroz, M. S. Estratégias de Consumo em Saúde entre Famílias Trabalhadoras. Cadernos de Saúde Pública, vol. 9, n. 3, p. 272-282, 1993.

Rainho, M. do C. T. A inventiva brasileira na virada do seculo XIX para o XX: Colecao Privilegios Industriais do Arquivo Nacional. Historia Ciencia Saude-Manguinhos, 3 (2): 319332, 1996.

Ribeiro, M. M. A ciência dos trópicos: a arte médica no Brasil do século XVIII. São Paulo: Hucitec, 1997.

Ribeiro, M. A. R. Lições para a história das ciências no Brasil: Instituto Pasteur de São Paulo. História, Ciências, Saúde-Manguinhos, vol. 3, n. 3, p. 467-484, 1997.

Ribeiro, M. A. R. Saúde pública e as empresas químico-farmacêuticas. História, Ciências, Saúde-Manguinhos, vol. 7, n. 3, p. 607-626, 2001.

Robinson, R. O grande livro da Cannabis. Guia completo do seu uso industrial, medicinal e ambiental. Rio de Janeiro, Jorge Zahar Ed, 1999.

Rosen, G. A History of Public Health. New York: The Johns Hopkins University Press, 1993.

Rumsey, H. W. Essays on State Medicine. London: John Churchill, New Burlington Street, vol. II, pp. 61-66, 2001.

Salles, M. do R. R. Médicos Italianos e a Prática Médica no Estado de São Paulo no Período da Grande Imigração. Boletim do Instituto de Saúde, n. 38, p. 28-31, abril 2006. 
Sally, S. Mary Seacole. Wonderful Adventures of Mrs Seacole in Many Lands. Penguin Books, 2005.

Santos Filho, L. de C. História Geral da Medicina Brasileira, v. 2, 1991.

Santos, K. M. O. dos; Barros Filho, A. de A. Consumo de produtos vitamínicos entre universitários de São Paulo, SP. Rev Saúde Pública, vol. 36, n. 2, p. 250-3, 2002.

Santos, L. A. de C. O pensamento sanitarista na Primeira República: uma ideologia de construção da nacionalidade. Dados. Revista de Ciências Sociais, Rio de Janeiro, vol. 28, n. 2, p. 193-210, 1985.

Santos, M. R. da C. Profissao Farmaceutica no Brasil: Historia, Ideologia e Ensino. Holos Editora, p. 1-54, 1999.

Santos, M. R. dos. Do boticário ao bioquímico: as transfromações ocorridas com a profissão farmacêutica no Brasil. Dissertação (mestrado). RJ: Escola Nacional de Saúde Pública, Fundação oswaldo Cruz, 174 p., 1993.

Schraiber, L. B. Histórias de médicos: vida de trabalho entre a prática liberal e a medicina tecnológica. Hist. cienc. saude-Manguinhos, vol. 4, n. 2, p. 345-363, Oct. 1997.

Scliar, M. Do Mágico ao Social: A Trajetória da Saúde Pública. Porto Alegre e São Paulo, L\&PM Editores, 1987.

Silva, M. R. B. O mundo transformado em laboratório: ensino médico e produção de conhecimento em São Paulo de 1891 a 1933. Tese (doutorado), Faculdade de Filosofia, Letras e Ciências Humanas, Universidade de São Paulo, 2003.

Silva, M.R.B. O surgimento da escola médica paulista no contexto brasileiro da Primeira República (1891-1930). Rhela, vol. 6, p. 305-316, 2004.

Singer, P.; Campos, O.; Oliveira, E. M. de. Critérios de avaliação dos serviços de saúde. In: Prevenir e Curar: o Controle Social através dos Serviços de Saúde, Forense-Universitária, Rio de Janeiro, 1978.

Smith, F.B. The People's Health 1830-1910, Croom Helm London, 1979.

Soares, M. de S. Médicos e mezinheiros na Corte Imperial: uma herança colonial. História, Ciências, Saúde-Manguinhos, vol. 8, n. 2, p. 407-38, 2001.

Sonnedecker, G. The Development in Britain. In: Kremers and Urdang's History of Pharmacy. Estados Unidos da América: American Institute of the History of Pharmacy, p. 99$121,1986$.

Souza, C. M. C. de. A gripe espanhola em Salvador, 1918: cidade de becos e cortiços. História, Ciências, Saúde - Manguinhos, v. 12, n. 1, p. 71-99, 2005.

Stead, J. The Diary of a Quack Doctor. Being the Last Diary of John Swift, Aurist of Newsome, Huddersfield, 1784-1851. Huddersfield Local History Society, 2002.

Stewart, A. P.; Jenkins, E. The Medical and Legal Aspects of SANITARY REFORM. Leicester University Press, 1969. 
Summers, A. Pride and Prejudice: Ladies and Nurses in the Crimean War. History Workshop 16, p. 32-56, 1983.

Teixeira, L. A. As febres paulistas na Sociedade de Medicina e Cirurgia de São Paulo: uma controvérsia entre porta-vozes de diferentes saberes. Hist Cienc Saúde-Manguinhos, vol. 11, suplemento 1, p. 41-66, 2004.

Teixeira, L. A. Uma Sociedade Médica em São Paulo. In: Na Arena de Esculápio: a Sociedade de Medicina e Cirurgia de São Paulo (1895-1913). São Paulo: Editora Unesp, p. 17-59, 2007.

Telarolli Junior, R. Vida material e política na primeira república. In: Poder e saúde. As epidemias e a formação dos serviços de saúde em São Paulo. São Paulo: Editora UNESP, p. 23-83, 1996.

Theml, N.; Bustamante, R. História comparada. Olhares plurais. Revista de História Comparada, vol. 1, n. 1, p. 1-23, junho 2007.

Thomas, K. Religion and the Decline of Magic. Studies in popular beliefs in sixteenth and seventeenth century England. Weidenfeld \& Nicolson, London, p. 177-279; 641-668, 1997.

Varlaam, C. The 1858 Medical Act: The Origins and the Aftermath. The Society for the Social History of Medicine, bulletin 21, pp. 31-33, 1977.

Waddington, I. The Medical Profession in the Industrial Revolution. Gill and Macmillan Humanities Press, 1984.

Wheeler, S. Henry Lilley Smith (1788-1859), surgeon, philanthropist and originator of provident dispensaries. A study of the career, ideas and achievements of a nineteenth century country doctor. MA dissertation, University of Warwick, p. 8-17, 1996.

Witter, N. A. Curar como Arte e Ofício: contribuições para um debate historiográfico sobre saúde, doença e cura. Tempo, Rio de Janeiro, n. 19, p. 13-25, 2005.

Worboys, M. Spreading Germs. Disease Theories and Medical Practice in Britain, 1865-1900. United Kingdom: Cambridge University Press, p. 1-42, 2000.

WORLD SELF-MEDICATION INDUSTRY. 2004. Disponível em: http://www.wsmi.org/aboutsm.htm Acesso em 15 de dezembro de 2007.

Zanini, A. C.; Sertie, J. A.; Gentil, V. Influência médica na ação de drogas: efeito placebo. Rev. Ass. Med. Brasil., vol. 22, p. 35-36, 1976.

Ziggi, A.; Dewjee, A. Mary Seacole: Jamaican national heroine and 'doctress' in the Crimean War. London: Brent Library Service, 1982. 